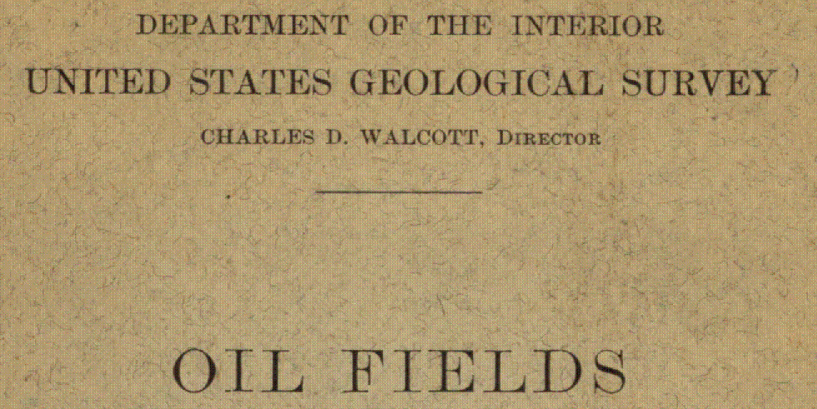

OF THE

Texas-Louisiana Gulf Coastal Plain

$\mathrm{BY}$

C. W. HAYES ANI WILLTAM KENNEDY

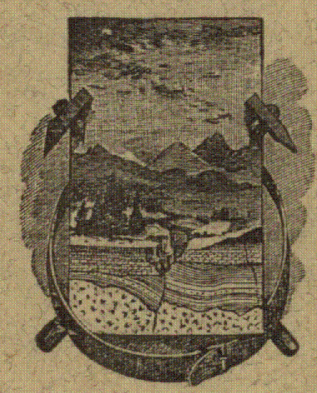

WASHINGTON

GOVERNMENT PRINTING OFFICE

1903 

DEPARTMENT OF THE INTERIOR

UNI'TED S'TA'TES GEOLOGICAL SURVEY

CHARLES D. WALCOTT, DIRECTOR

\section{OIL FIELDS}

OF THE

\section{Texas-Louisiana Gulf Coastal Plain}

BY

C. W. HAYES ANI WILLIAM KENNEDY

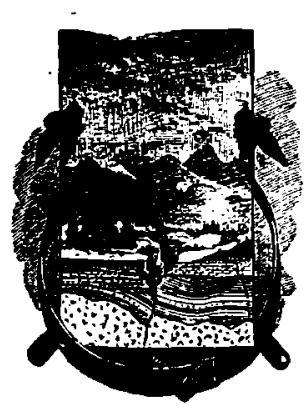

W ASHINGTON

GOVERNMENT PRINTING OFFICE

1003 



\section{O NTENTS.}

Page.

Acknowledgments

Previous knowledge of the region $\ldots \ldots$

Topography of the Gulf Coastal Plain .

Relief

Drainage $\ldots \ldots \ldots$

Timber $\ldots \ldots$

Geology of the Gulf Coastal Plain $\ldots$

Subdivisions . . . . . . . . . . . . 15

Geology of the western division ............... 16

Surface formations . . . . . .

Underground conditions $\ldots \ldots \ldots \ldots \ldots \ldots . .18$

Section from Pleasanton to Palito Blanco ...................... 18

Prospecting for petroleum ..................... 19

Geology of the eastern division 19

General section . . . . . .

Base of coastal formations .

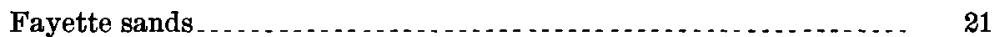

Frio clays . . . .

Buried beds . . . . . . . . . . . .

Lafayette sands . . . . . . .

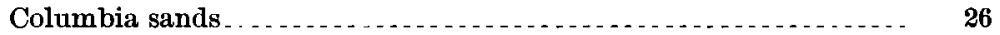

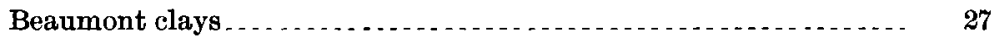

Recent or Port Hudson clays $\ldots \ldots \ldots \ldots \ldots$

Detailed sections of Coastal Plain formations . ................ 30

Detailed sections on the Guadalupe........................ 30

Detailed sections on the Colorado and Brazos ................ 32

Detailed sections between Brazos and Trinity rivers............... 42

Detailed sections in vicinity of Neches and Sabine rivers . . . . . . . 48

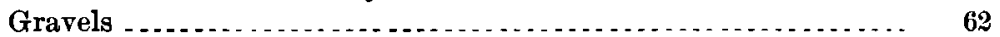

Changes of level during deposition of Coastal Plain formations ....... $\quad 66$

Geology of the oil pools $\ldots$

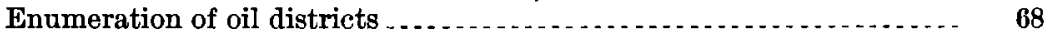



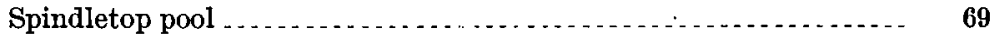

Limits of Spindletop pool $\ldots \ldots$

Character of overlying beds $\ldots \ldots \ldots$

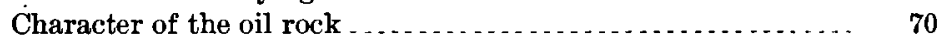

Beds underlying the oil rock ............................ 71

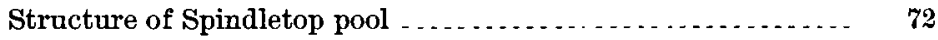

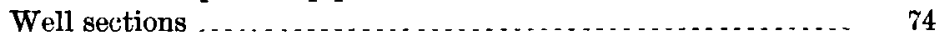

List of producing wells in Spindletop pool ............... 77 
Geology of the oil pools-Continued.

Beaumont district-Continued.

Page.

Region surrounding Spindletop pool.......................... 86

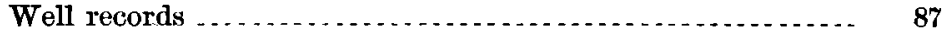

List of wells ....

Port Arthur-Sabine Pass district . . . . . . . . $\ldots \ldots \ldots$

Oil ponds. . . . . . . . . . . . . . . .

Examination of mud from Gulf of Mexico, by H. J. Turner. .. 107

Sea wax . . .

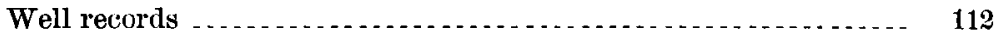

Sour Lake district $\ldots \ldots \ldots$

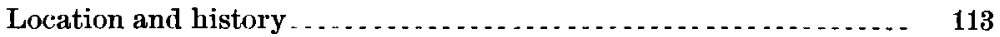

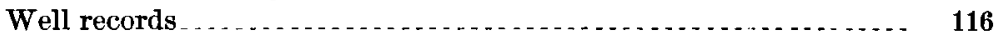

Geologic structure $\ldots \ldots \ldots \ldots \ldots \ldots$

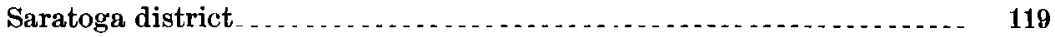

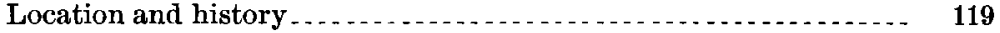

Well records . . . . . . . . . . . . . . . 119

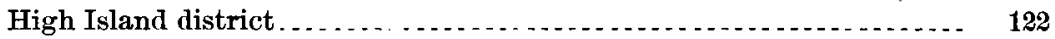

Location and topography .................................. 122

Well records .............................................. 124

Geologic structure $\ldots \ldots \ldots$

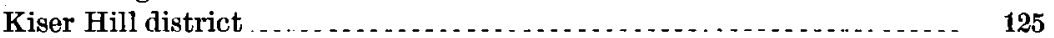

Minor Texas districts $\ldots$

Big Hill, Jefferson County . . . .

Dayton Hill ............... 126

Barber Hill . . . . . . . . . . . .

Davis Hill . . . . . . . . . . . . . . . . . 127

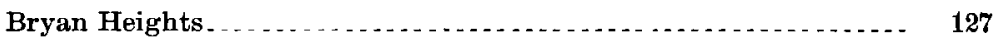

Big Hill, Matagorda County .............................. 127

Jennings district . . . . . . . .

Location and development .......................... 127

Oil sand

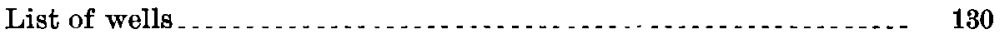

Anse La Butte district . . . . . . 130

Hackberry Island . . . . . . . . . .



Minor Louisiana districts . . .



Spring Hill ....

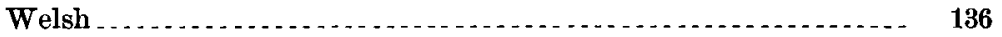

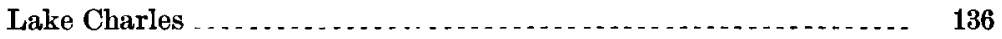

Other localities .

The Gulf Coastal Plain oil _...................................... 137

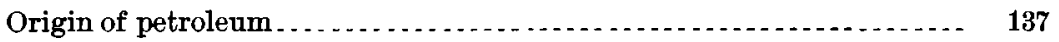



Theories of inorganic origin . . . . . . . . . .

Theories of organic origin ................................ 138

Theories of combined organic and inorganic origin.............. 139

Conclusion ............................................. 140

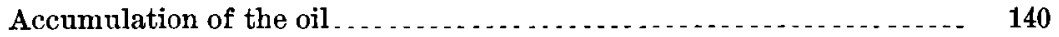

Conditions for accumulation . . . . . . .

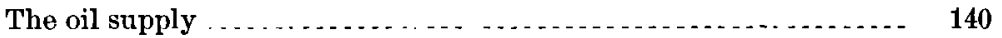

The reservoir rock . . . . . . . . . . . . . .

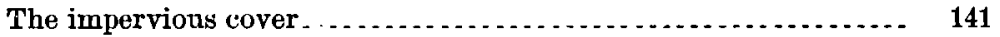


The Gulf Coastal Plain oil-Continned.

Page.

Accumulation of the oil-Continued.

Anticlinal structure ........................................ 142

Saturation of the rocks and circulation of the saturating fluid ... $\quad 142$

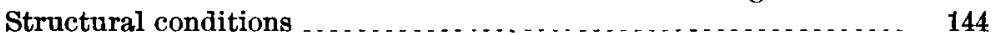

Physical and chemical properties of the Texas-Lonisiana oil . . . . . . . . 146

Physical properties . . . . . . . . . . . . . 146

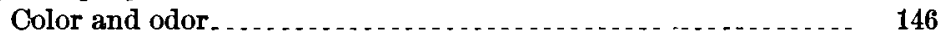

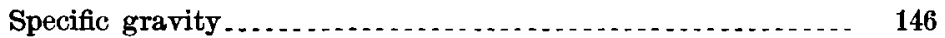

Flash and burning point ................................ 147

Viscosity ... . . .

Chemical properties

Composition $\ldots \ldots \ldots$

Volatility $\ldots \ldots \ldots$

Constitution . . . .

Associated hydrocarbons . . .

Natural gas. . . . . . . . . .



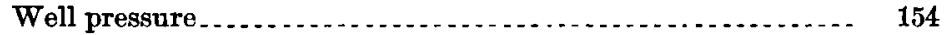



Utilization of the Gulf Coast petroleum ........................ 157

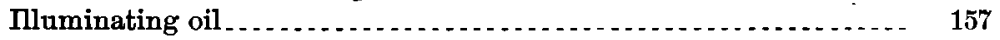

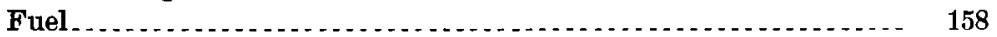

Theoretical value $\ldots \ldots \ldots \ldots$

Safety $\ldots \ldots \ldots$

Practical tests in steam raising . . . . . . . .

Comparative fuel value of coal and Beaumont petroleum . . . . 160

Locomotive tests. ..................................... 161

Methods of burning the oil .................

Storage and transportation

Methods and cost of well drilling.............................. 166



Machinery and operation $\ldots \ldots$

Cost of drilling . . . . . . . .

Finishing the well $\ldots \ldots \ldots \ldots \ldots \ldots$

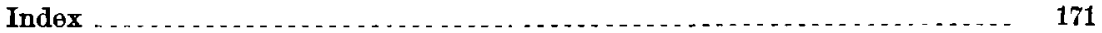





\section{L L USTRATI O NS.}

Plate I. Geological map of a portion of the Gulf Coastal Plain. .......... 14

II. Generalized section of the Texas-Louisiana Gulf Coastal Plain for-

formations........................................... 20

III. Map of Spindletop oil pool .............................. 68

IV. View of a portion of Spindletop, 1902 . . .

V. Index map showing location of Louisiana oil districts . . . . . . 128

VI. Sand gusher at Welsh, La _ . . . . . . . . . . . . . . . . 136

VII. Map of petroleum fields . . . . . . . . . . . . . . . . . . . . . . 144

VIII. $A$, Williams burner, section through center of burner; $B$, Williams burner, horizontal section through center of burner ..... 162

IX. Babbitt syndicate earthen oil reservoir...................... 164

$\mathrm{X}$. A, Chapman rotary drill: $B$, Hoisting and operating machinery - 166

XI. $A$, Fish-tail bit; $B$, Core-barrel bit; $C$, Adamantine or shot drill $\quad \mathbf{1 6 8}$

Fic. 1. Sketch contour map of Damon Mound .................. 36

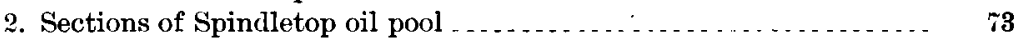

3. Map of region surrounding the Spindletop oil pool $\ldots \ldots \ldots \ldots \ldots . .86$

4. Map of Sabine Pass, showing location of so-called oil pon As . . ... 105

5. Index map showing location of Sour Lake and Saratoga oil pools - 114

6. Map of Sour Lake district . . . . . . . . . . . . . . . . . . . . . . . . . . . 115

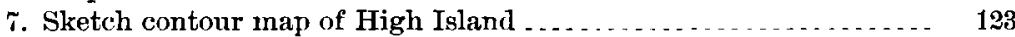

8. Map of Jennings oil field .... . . . . . . . . . . . . . . . . . . . . . . 128

9. Theoretical relations of gas, oil, and water in the reservoir rock .. 15\%

10. Boiler furnace with oil-burning equipment $\ldots \ldots \ldots \ldots \ldots \ldots \ldots$

11. Boiler furnace arranged for burning oil . . . . . . . . . . . . . . . . . . . . 164

12. Derrick with machinery in place......................... 168 



\title{
OIL FIELDS OF THE TEXAS-LOUISIANA GULF COASTAL PLAIN.
}

\author{
By C. W. Hayes and William Kennedy.
}

\section{IN'TRODUC'TION.}

Immediately after the discovery of the Spindletop oil pool by Capt. A. F. Lucas in January, 1901, there was a widespread demand for information regarding the geology of the Gulf Coastal Plain in Texas and Louisiana. Very little was known concerning the formations underlying this region, for owing to the lack of exposures it had presented an extremely uninviting field for investigation. It was believed that the interests of the oil-producing industry would be best served by a thorough study of the stratigraphy of the region and the collection of all data regarding the character of the underlying beds obtainable from natural exposures and well records. Only upon such a foundation of carefully ascertained fact could any reasonable hypothesis regarding the origin and distribution of the oil be based. Many theories have been published in the daily press and elsewhere, which have been more or less fanciful, not to say grotesque, and which have cast a shade of discredit upon geology by those who do not take the pains to discriminate.

For the purpose of collecting all available stratigraphic data in this region the Survey obtained the services of Mr. William Kennedy, formerly of the Texas geological survey. During his connection with the State survey Mr. Kennedy examined a large part of the Gulf Coastal Plain, but only a portion of his results was published. He began work for the present report in June, 1901, and continued in the field until February, 1902. About eight weeks were spent in the field by the senior author in the fall of 1901 and the spring of 1902, the more important and promising localities being visited. Owing to the press of other duties the preparation of the following report has fallen almost entirely upon Mr. Kennedy. He is to be given the entire credit for all the stratigraphic descriptions which form the chief permanent value of the report. He has also worked out the Tertiary history of the Coastal Plain, which is a distinct contribution to geologic science and is essential for a theory of oil accumulation in this region. 


\section{ACKNOWLEDGMENTS.}

Acknowledgments are due to the various oil companies and their managers, as well as to individual drillers in the various portions of the Coastal Plain, for assistance in various ways and for information given by them during the course of the work. Thanks are due more particularly to W. E. Griffith and J. M. Landon, of the J. M. Guffey Petroleum Company; to Walter and J. M. Sharp, of Sharp Brothers; to George A. Hill, of the safety committee; to W. H. Mitchell, of the Gladys Oil Company; to J. Harbey, of the Harbey Oil Company; and to W. A. Andrews, of the Slanghter-Masterson Company. Also to H. H. Jones, of Hackberry, and Lee Hager, mining engineer, for information regarding the Louisiana field; to II. S. Hargraves, of Saratoga, and Messrs. Heaton and 'T. O'Connor, of Victoria and Cuero, for assistance in Victoria, Dewitt, and Calhoun counties. Without the assistance of these men, much of the information here given would not have been obtainable.

\section{PREVIOUS KNOWLEDGE OF THE REGION.}

From the Mississippi River westward through Louisiana and Texas, along the border of the Gulf of Mexico, is a low, flat country, partly swampy or marshy, as in the southern parishes of Louisiana, and partly a broad stretch of clayey and sandy land but slightly elevated above the level of these marshes. The marshy areas extend westward to the eastern shore of Galveston Bay, while the clayey areas may be said to extend as far west as the Guadalupe River, in Victoria County, Tex. IVest of that stream, as far as the Rio Grande, the country is covered with sand and has a semiarid aspect. It may be added that this condition exists for many miles along the coast of the Mexican State of Tamaulipas. This region is known as the Gulf Coastal Plain. It extends inland for a distance of from 50 to 100 miles. Although forests of pine, oak, and magnolia fringe its northern border on the higher grounds, various species of gum occur on the lower benches, and heavy forests of black and red cypress oceupy the low river flood plains, the greater portion of the Coastal Plain is a treeless prairie.

These prairies have usually been designated the Coast prairies, and the beds which occupy the surface within the area are glouper under the general title of Coast clays. No geologic work of any magnitude has ever been done in this prairie region, partly because the country was not considered of any economic value, and partly on account of the difficulties caused by the absence of anything like a natural section. The country is very flat, there are few streams flowing across it, and these few are flowing through broad, shallow channels filled with recent alluvium.

The only references made to these coast deposits in the published 
reports of the Texas State Geological Survey have been cursory and of a very general character. The most important is as follows:

Immediately bordering the Gulf shore and forming the underlying slope we find a series of beds of clays, sandy clays, blue, yellow, red, and often mottled, which frequently appear black upon the surface from the combination of vegetable matter with the lime of the calcareous nodules, which are found scattered through them. These clays are heavy, massive, containing small crystals of gypsum in places, and so compact that bluffs from 15 to 20 feet in height are often found along the streams and bay shores even in such a moist climate as that of Texas.

The various strata which form these beds dip so slightly to the sontheast as to appear nearly horizontal, and form the basis of the level coast prairies which stretch inland from the Gulf for distances varying from 50 to 100 miles.

While the underlying beds of clay are seemingly identical for the entire Gulf coast, the overlying soil is somewhat different, being more sandy on the eastern and western borders and more clayey between the Brazos and Nueces rivers. $a$

McGee regarded these deposits as belonging in part to his Lafayette formation and in part to his Columbia. He considers the region to have been built up for the most part from long wave-built keys separated from the mainland by sounds, although he says that " east of Galveston the keys and sounds appear to fail; yet the wave-built barriers are continuous as in southern Texas and eastern Mexico, though submerged beneath the Gulf waters to form Sabine Bank, Trinity Shoals, and Ship Shoal, and their connecting series of bars parallel with the coast." $b$

R. T. Hill describes these plains as a belt of prairie land not over 100 miles wide bordering the Gulf of Mexico in Louisiana and Texas. He regards it as a grass-covered constructional plain newly reclaimed from the Gulf of Mexico. The interior margin of this plain rises scarcely 100 feet above the sea, and it is characterized by an exceedingly level surface hardly broken except by a few low drainage grooves, which become fewer and more faintly developed toward the Rio Grande. Upon this plain a youthful drainage system is being established, while the seaward extensions of the through-flowing streams cross it. 'These rivers have wide and deeply indented valleys with gently terraced slopes filled with old alluvium.

The floor of the sea border of Texas is a submerged gently sloping sandy plain, or shelf, extending 50 miles seaward. By action of tide, wave current, and wind this sand is piled into long island strips which fringe the coast and stand almost at sea level. These are separated from the land by shallow lagoons, in which most of the sediments of the river are deposited. The building np of the sand bars by wind and wave and the filling up of the lagoons between them by river sediments, in connection with gradual uplift, may possibly explain the origin of much of the adjacent coast prairie. ${ }^{e}$

Sufficient work has not been clone in southwestern Louisiana to give us any clue to the structure of that portion of the Coastal Plain. 
According to Hilgard, this portion of the coast country is built up partly of littoral and esturine deposits and partly of swampy lagoon and fluviatile deposits, whose thickness and location are manifestly dependent upon the topographic features of the continent at the time they were laid down. The land at that time was being slowly depressed, as is shown by the nature of the deposits and by the numerous superimposed generations of large cypress stumps embedded in laminated clays, which exhibit the yearly fall of leaves. This view was also held by Hopkins in his survey of southwestern Louisiana in $1870-71$.

The theories regarding the upbuilding of the Coastal Plain may possibly apply to the newest extension in the east, along the Gulf of Mexico, which at present is altogether marshy, or to the comparatively arid region west of the Nueces River, where at present we find a chain of such keys with their accompanying lagoons. The largest of these lagoons-Laguna de la Madre-is being rapidly filled up by the drifting sands from the higher dunes of Padre Island.

A study of the submerged portion of the Coastal Plain, as shown by the Coast Survey charts, shows that the general slope of the sea floor as far out at least as the 5-fathom, or 30-foot, line is not more than 5 to 7 feet per mile, and that there cloes not appear to be any uniformity in the deposition of the materials forming this floor. Lens-shaped deposits of hard blue clay and soft mud occur, irregularly interspersed with banks of fine and coarse gray sand and broken shells. The Sabine Bank is reported as being inade up of a gray sand, with black specks and broken shells, which closely resemble much of the gray sand obtained from the different wells in the southeastern portion of the oil fields, especially in the neighborhood of Beaumont. It is probable that the upbuilding of the Coastal Plain, at least throughout about 500 feet of its upper portion, was carried on in the same manner as at present. Under the present Gulf the sands appear to be the heaviest deposits, and the well records show the same conditions to exist down to a depth of 500 feet.

The existence of petroleum in this portion of the country has been known for many years. In 1860 Wall, quoting from Taylor's Statistics of Coal, mentioned the existence within 100 miles of Houston of a small lake filled with bitumen or asphaltum, and having in its center a spring from which during the summer months an oily liquicl (probably petroleum) continually boiled up from the bottom."

In 1880 S. F. Peckham quotes N. A. Taylor as to the existence of maltha in Texas, and gives Sour Lake as one of the localities. On the map accompanying his report oil-producing localities are marked as follows: At the mouth of the Brazos, near the point where the $J . M$. Guffey Petroleum Company is now drilling; close to Port Arthur, in 
Jefferson County; in Newton and Orange counties, Tex.; and at several points in Calcasieu Parish, La. ${ }^{a}$

When the present oil development began it was considered advisable to undertake the study of the Coastal Plain in order to bring together such geologic information as was available concerning the geologic relations of the various deposits and to assist in the economic exploitation of the oil fields.

With this object in view the Gulf Coastal Plain was thoroughly studied. The various deposits of sands, clays, and sandstones were examined and compared, their continuity across the country was traced, their geologic conditions were studied, and their position in the general section of the region was worked out. This has been done as far as possible by means of the small bluffs and cuttings seen along the courses of the rivers and creeks, as well as of such enttings as could be found along the various railroads traversing the country. In addition, the logs of the various deep wells throughout the whole Coastal Plain, so far as obtainable, were gathered, and the results of the borings collated and compared.

By these means the general underground conditions of the region to a depth of about 2,000 feet have been determined and have been described so as to be readily understood by those immediately interested in the development of the field. There are, however, many questions regarding the underground structure that can not be answered until much more drilling has been done.

\section{TOPOGRAPIIY OF TIE GULF COASTAL PLAIN.}

That portion of the Gulf Coastal Plain under discussion may briefly be described as a belt of country having a width of from 50 to 100 miles, extending around the shores of the Gulf of Mexico and embracing in Louisiana, in whole or in part, the parishes of Vermilion, Acadia, Cameron, Calcasieu, and Vernon; and in Texas the counties of Orange, Newton, Jefferson, Hardin, Jasper, Chambers, Liberty, Harris, Galveston, Brazoria, Matagorda, Fort Bend, Wharton, Jackson, Victoria, Calhoun, Refugio, San Patricio, Nueces, Cameron, Hidalgo, and portions of Waller, Montgomery, San Jacinto, Polk, and Tyler.

\section{RELIEF.}

The surface features of the Gulf Coastal Plain are extremely simple. In the immediate vicinity of the coast and for 15 or 20 miles inland in the parishes of Vermilion and Cameron and in the counties of Orange, Jefferson, Chambers, and Galveston, the general level is searcely more than 3 or 4 feet above the average tides of the Gulf. At a few points, such as Grand Chenier and Hackberry Island, in Cameron Parish, La., and Big IIill and IIigh Island, in Jefferson and 
Galveston counties, Tex., there are pronounced elevations, of a few hundred acres in extent, rising to heights of from 40 to 50 feet above the level of the coast marshes.

Bordering the marsh along its northern edge is a second belt, largely prairie land, whose surface rises gradually toward the northwest, at an average rate of from 10 inches to a foot per mile.

$\Lambda$ few small prominences appear within this belt, as at Spindletop and Fairchild IIill, in Jefferson County; at Sour Iake, Dayton, Barber Hill, Kiser Mound, near Columbia, and Damon Mound, in Brazoria County; and the Sun Mounds, in Waller County. These, however, do not present any great elevations, Damon Mound, probably the highest, having a maximum of 83 feet above the plain, or probably not more than 140 feet above the Gulf.

The third or immer belt of country belonging to the Coastal Plain rises comparatively rapidly from the second, and has a more broken and generally timbered surface, with numerous small rounded hills. The general elevation of this belt does not appear to exceed 175 to 200 feet above sea level.

DRAINAGE.

In the castern part of the region throughout Louisiana the rivers are deep and sluggish. The few streams of any magnitude are the Vermilion Bayou, Bayou Nementou, and Calcasieu River. Each of these streams is narrow, deep, and clear, has scarcely any appreciable current, tends to expand into a broad, shallow lake, and enters the Gulf through a shallow bay. Vermilion River flows into Vermilion Bay. The Nementou shortly after the junction of Bayou Nezpique and des Cannes expands into the broad, shallow Grand Lake, with a depth of little over 3 feet, and again contracts only to enter the Gulf through a wide mouth. The Calcasieu forms a series of shallow lakes such as Calcasieu, Black, and West Lake, extending all the way from Lake Charles to the coast. These Louisiana rivers all have the peculiar characteristics of drowned or submerged streams.

Throughout the Coastal Plain in southeast Texas the, streams are similar. in character to those in Louisiana. The Sabine and Neches unite to form Sabine Iake; the Trinity debouches into the eastern end of Galveston Bay; the Colorado reaches the Gulf through Matagorda Bay, and the Nueces flows into Corpus Christi Bay. Of all the rivers in this area the Brazos alone enters the Gulf directly and without the intervention of any lagoon or bay.

West of the Nueces the coast drainage fails almost absolutely, as the whole stretch of coast line to the Rio Grande contains only two small creeks, the San Fernando and the Olmos, and these unite to form Copano Bay, near the head of Iaguna do la Madre.

These streams of the Gulf Coastal Plain may be divided into two groups-an older, pre-Pleistocene or pre-Columbia, and a younger, 


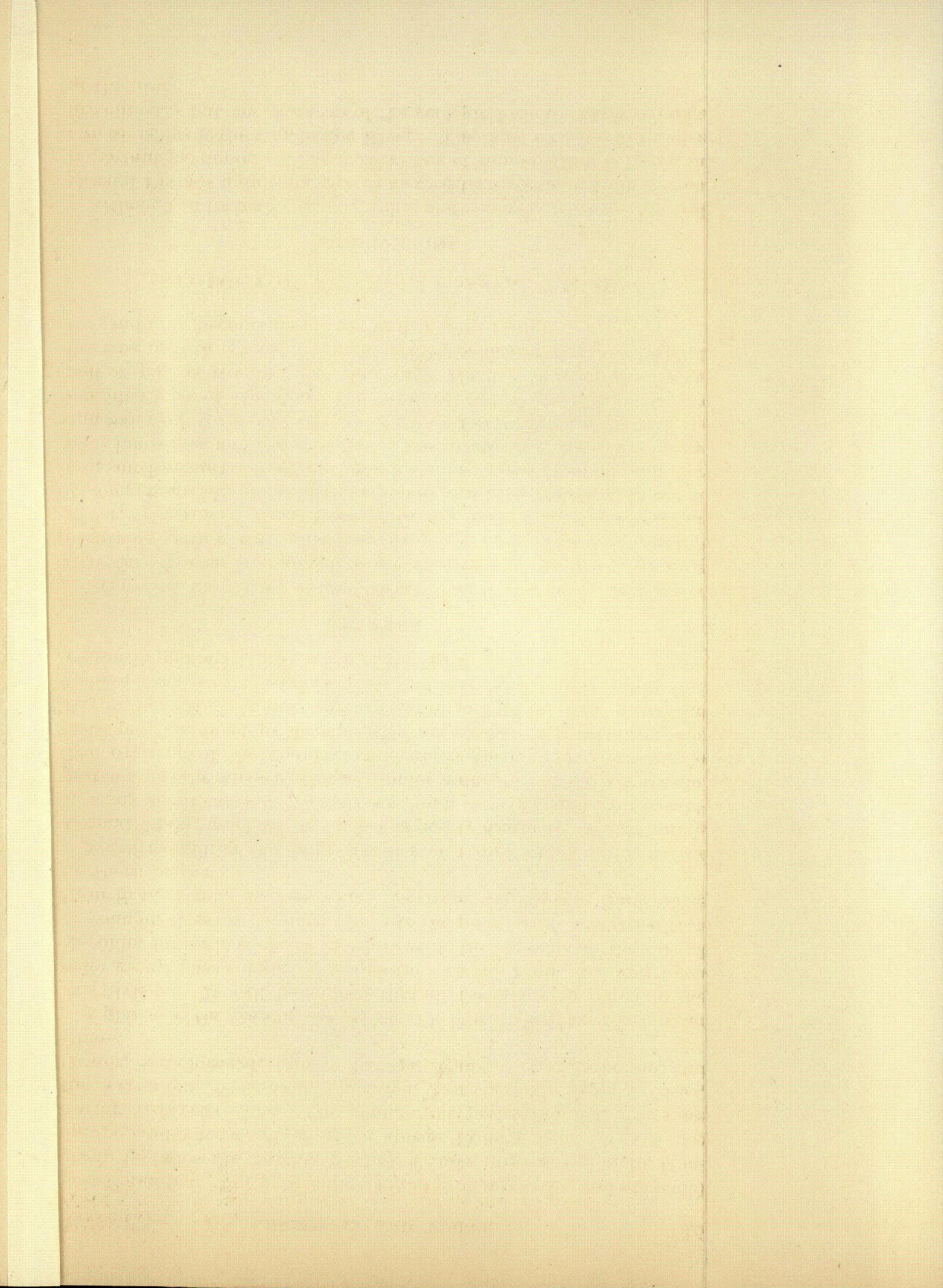


post-('olumbia. The pre-Columbia (and probably even pre-Lafayette) group includes the Sabine, Neches, Trinity, Brazos, Colorado, Guadalupe, and Nueces, all of which appear to have been in existence during Lafayette time. The younger, or post-Columbia, rivers are the Vermilion, Nementou, Calcasieu, San Jacinto, Buffalo, Clear, Oyster, San Bernard, Caney, Lavaca, Aransas, San Fernando, and Olmos.

A glance at the map of the region (Pl. I) will show the reasons for this division. It will be noticed that all the rivers included in the older group pass completely across the Coastal Plain, heading upon the older formations of the interior, while the streams of the second or younger class are confined wholly to the plain itself, heading within it, or in the strong springs which rise from the Fayette sands at its northern border:

Notwithstanding the large number of rivers which oceur in the Cuastal Plain, much of its surface is poorly drained. Water stands in many small lakes or ponds throughout the year, and over considerable areas the surface is largely under water during the wet season. The drainage of the country, particularly throughout the lower or coast portion, develops some peculiar anomalies. For instance, Mud Bayou, near High Island, begins within a mile of the Gulf shore, but follows a series of meanders north and west, and finally enters Galveston Bay about 2 miles north of the Gulf.

\section{TIMBER.}

Regarding the timber of the Coastal Plain it may be broadly stated that the cypress is confined to the eastern end, or to the swamps occurring within the immediate drainage area of the Mississippi River, very few of these trees oceurring west of the Sabine River. The magnolia ( $M$. grandiflora) is found in a belt stretching in a general southwestern direction through the parishes of Sabine and Vernon, Louisiana, and the counties of Newton, Jasper, Iardin, Liberty, and San Jacinto, Texas, terminating in a few straggling trees in the neighborhood of Houston. The western end of the great southern belt of pine is reached near the Brazos River. West of the Brazos the tree growth is mostly represented by oaks and mesquite, the latter gradually becoming the only timber to be found.

\section{GEOLOGY OF THE GULF COASTAL PLAIN.}

\section{SUBDIVISIONS.}

Although in its main physiographic and geologic features the Gulf Coastal Plain is a unit, its eastern and western portions differ in some important particulars. The natural line of demarcation between the two divisions is the Guadalupe River. The most striking differences are climatic, but the character of the geologic formations also changes at this line. 


\section{GEOLOGY OF THE WESTERN DIVISION.}

Little detailed study has been given to this division, and it has little present importance in connection with oil production. Its main characteristics may, however, be briefly outlined.

\section{SURFACE FORMATIONS.}

Brown and gray sand appear to be the mantle covering everything from the border of the Fayette sandstones on the north to the coast. In going southward from San Diego a belt of brown sand, probably 25 miles in width, is first crossed. This is a rolling country more or less covered with mesquite and chaparral. South of this comes the gray sand belt, having a width varying from 50 to 60 miles, and, with the exception of a fow live oaks, practically destitute of trees. This is the region described by Loughridge, in his report on cotton production for the Tenth Census, as the great Texas desert. Across the face of these gray sands stretch two belts of moving sandhills, or medanos. These belts have an approximately east-west direction, as the prevailing winds are from the east. Each belt consists of a double row of dunes from a half mile to a mile apart, the one row overlapping the other. Near the coast most of these dunes or medanos appear only as white spots slightly elevated above the general level of the plain. As they travel westward the dunes gradually acquire size and elevation until in northern Starr County some of them have reached elevations of from 90 to 120 feet. In form these dunes are usually semilunar, having the heavy body of sand toward the center and the two ends tailing off to the west to form the horns of the erescent. Some of them are almost circular, with a depression in the center; others are oval, with their longer axis parallel with the course the hill may be traveling. Nothing appears to stop their westward course, and in several instances tall live oaks have been buried so deeply that only the dead tops of the highest branches show the fate of the grove.

The sand forming these hills is extremely fine in texture and has a snow-white color. The crests of the dunes assume fantastic shapes, and the lightest wind sets the fine grains in motion. 'These dunes are very difficult to ascend, the climber sinking almost to the knee at every step, and, owing to the fineness of the particles, his eyes, mouth, and nose are almost constantly filled with sand.

These dune belts lie almost parallel to each other, the first or northern line stretching across the country through the northern ends of Cameron, Hidalgo, and Starr counties, and the second or southern belt extending across the same counties about 50 miles farther south.

The blue clays underlying the sands do not appear in many places and very little is known about their stratigraphy or areal extent. They may be the equivalents of the white and yellow clays forming 
the bluff in the neighborhood of Corpus Christi, and possibly should be correlated with the blue clays of the east and form a portion of Hilgard's Port Hudson or McGee's Columbia.

Probably underlying these clays is the Reynosa limestone, typically a tufaceous lime rock, but frequently so mixed with clays and sands as to almost lose its identity. Included with the Reynosa division are several beds of conglomerate, consisting of pebbles and gravel cemented together by a limy matrix, together with gravels and limy clays.

The Reynosa limestone is by far the most important member of the Coastal Plain group as seen in the south western end. It is exposed high up on the northern side of the range of hills bordering the southern margin of the Nueces River Valley in McMrullen County. Where the Nueces has broken through this range the Reynosa limestones can be traced like an old shore around the end of the range and along its southern side, where the limestone is found high up on the flank and caps the lower levels of the hills south of San Diego. It occurs at Rogers, a few miles west of Corpus Christi, and at several points on the prairie in upper Hidalgo and Starr counties, and may possibly be found in other areas.

In connection with the apparent trend of the Reynosa beds in a general north-south direction, it is noticeable that these limestones are directly associated with gypsum deposits in the upper end of Hidalgo and Cameron counties, and with the heavy salt deposits of the Sal del Rey region in southern Texas. Disagreeable-smelling sulphur water flows from a deep well at Corpus Christi, and small outcrops of sulphur clays appear in the Rio Grande country near Rio Grande City.

The Reynosa limestone with its associated elays, conglomerates, and marls has been considered of Pliocene age.

Pleistocene deposits containing vertebrate fossils have been recognized in the Equus beds in the neighborhood of San Diego, although some doubt has been thrown on the age of these deposits, Cope considering them to be Upper Pliocene. As in the case of the underlying Miocene deposits of the Bordas distriet, not enough work has yet been done to determine their areal extent or even to absolutely prove their existence. The beds here considered as Miocene, unlike any other deposits of Tertiary age in Texas, are all standing up at very high angles, in many places showing dips of $75^{\circ}$ or $80^{\circ}$. This is the more noticeable in the southwest corner of Live Oak, northeast corner of Duval, and southeast corner of McMullen counties. Many of the smaller dome-shaped hills have the appearance of having been formed by a thrust from below, the saudstones forming them dipping in every direction.

Bull. 212-03-2 


\section{LNDERGROUND CONDITIONS.}

Throughout this portion of the Coastal Plain the actual geologic conditions underground are unknown. Numerous shallow wells ranging from 100 to 300 feet in depth have been drilled for water. The drillers report rock in a number of these wells at 50 feet and then a mixture of rock, clay, and sand to the bottom of the wells. Few wells of greater depth have been drilled. Years ago the State made arrangements for the drilling of a number of test wells for water in this region and proposed to pay for these by granting sections of land. Under this arrangement one well was commenced at "Magueyes," on the eastern side of Hidalgo County, but to what depth it was drilled is unknown. The next deep well was drilled at Corpus Christi to a depth of 1,765 feet. This well gives a small flow of very disagreeablesmelling sulphur water. Several wells having depths ranging from 500 to 750 feet have been drilled for water on the Santa Gertrudes ranch, in western Nueces County, and yield strong artesian flows. $\Lambda$ well at Alice is reported to have a depth of 1,000 feet. Northward, in the gray sandstone regions, the public well at Tilden has a depth of 600 feet, giving a strong flow of brackish water with gas. This well was drilled in rock with thin partings of clay. Twelve miles south of 'Tilden, at Shiner's ranch house, a well 900 feet deep gives a small flow of strong salt brine.

So far as our knowledge of the structure of this region goes, it appears that the Fayette sandstones had formed the shore line for a considerable period and had been extensively eroded before the succeeding beds were laid down. The evidences of unconformity are plentiful. The Pliocene Reynosa limestone lies high up on the hillsides, and also appears to form ridges on the gray, sandy plain. This, it is true, would give these limestones a gentle dip of about 10 feet per mile, but as the surface relief is greater than that, much of these deposits must have been destroyed. Whether these Reynosa limestones ever formed the surface or floor of the plain, and the existing ridges are due to erosion, or whether they form the crests of small anticlines brought up by some earth movement, is not known.

\section{SECTION FROM PLEASANTON TO PALITO BLANCO.}

$\Lambda$ generalized section across this portion of the Coastal Plain from Pleasanton to Palito Blanco shows the following beds, in descending order :

Section of Coastal Plain from Pleasanton to Palito Blanco.

1. Brown sands of Coastal Plain.

2. Blue clays.

3. White or lemon-yellow limestones.

4. White, yellow, and brownish-yellow clays.

5. Thinly bedded gray sandstones, with white and gray clays.

6. Thinly bedded gray sandstones and gray clays.

7. Marine fossiliferous brown sand, with more or less gypsum in crystals.

8. Lignitic beds found in wells at Pleasanton. 


\section{PROSPECTING FOR PETROLEUM.}

Prospecting for petroleum in this region is not being carried on very vigorously. For a number of years petroleum has been obtained from a well in the northwestern part of Starr County, but the quantity is so small that the oil is usually drawn up by an ordinary water bucket and is sold to local consumers for medical purposes.

A well has recently been drilled at Piedras Pintas, near benavides, on the Mexican National Railroad, in Duval County, to a depth of 1,200 feet. Small quantities of oil were found at various depths, but not enough to justify further developments, and the work has been abandoned. This well is in the sandstone region near the northern margin of the Coastal Plain and has an elevation above sea level of 400 feet.

Another well, irilled on the La Parra ranch, in the northern portion of Cameron, to a depth of 1,500 feet, has been abandoned. The contractor states that he drilled through clay and sand the whole depth.

\section{GEOLOGY OF THE EASTERN DIVISION.}

GENERAL SECTION.

The general section of the Texas 'Tertiary formations shows considerable variation in the character and thickness of the various beds, and there are such extensive erosions and overlaps that it is somewhat difficult to say whether some of the beds actually occur at a stated locality or at what depth the rocks belonging to the given stage may be found. The beds thicken and thin rapidly, and change frequently from soft sand to indurated sandstone, while the clay bodies all appear to have a somewhat wavy or lenticular form.

In the following section the maximum thicknesses have been given, as it has been thought better to place before the well driller the utmost thickness of any of the beds he may be expected to go through. But, as will be pointed ont later, this section will be materially modified as to the thicknesses by the location of the well.

The section down to the Eocene is constructed chiefly from well records: It has been thought best, for clearness of presentation, to give a generalized description of the various formations which make up' the Coastal Plinin, to be followed by the detailed sections and local descriptious on which it is based.

General section of eastern division of Texas-Louisiana Gulf Coastal Plain.

1. Recent: Coastal marshes consisting chiefly of sea flats subject to Thickness overflow at extremely high tides, swamps and partly submerged lands, and the bottom lands along the rivers. The life represented by recent shells, such as Rangia cuneata and Ostrea. Beds of these shells occur along the rivers and at many of the smaller lakes in this region. 
2. Pleistocene, with probably some Pliocene.

a. Beaumont clays: Brown, blue, and yellow clays, carrying nodules of limestone in places irregularly distributed through the clays, making the soil black where found; brown and blue sands with great quantities of cypress wood and recent shells

b. Columbia sands: White, yellow, gray, and mottled sands with beds of blue and yellow clay, some decayed wood, and a heavy deposit of gravel at base. In the clays belonging to these beds at Sour Lake such vertebrates as Mommut, Megalonyx, Equus, Smilodon fatalis, etc., have been found $a$.................

3. Neocene (Miocene, with probably some Pliocene).

a. Lafayette sands: Blue and red thinly laminated clays; massive red and brown clays; and red and brown cross-bedded sands and gravels carrying pinkish inclusions of clay . ............

b. Blue, brown, and gray clays; sands with thin beds of limestone and containing. small quantities of oil . . . . . . . . . . . . . . . . . .

c. Blue clays and thin-bedded irregularly deposited sandstones...

d. Blue, red, and gray clays and sands and thin-bedded limestones; limestones dolomitized and associated with sulphur, gypsum, 4. Eocene. gas, and petroleum. Sands carry fossils of Miocene age .....

a. Frio clays: Blue, brown, red, yellow, and green clays, thinly laminated, partially stratified and massive. The laminated clays carry small crystals of gypsum and the massive clays numerous concretions of lime from 2 to 4 inches in diameter and calcareous-ferruginous concretions from 6 inches to 2 or more feet in length. Fossiliferous in places and changing to saudy calcareons clays to the west . . . . . . . . . . . . . . . . . . .

b. Fayette sands: Gray sands and gray and white sandstones interstratified with gray, white, and pink clays and sandy clays. The lower sandstones are often hard and glassy, and bluish or pinkish in color. The upper sandstones are soft and chalky white, and contain numerous casts of grass, reeds, palmetto, and other marsh plants. At some localities a thin bed of limestone in these upper sandstones carries Lower Claiborne fossils, and a yellowish-brown sand contains a considerable number of plant impressions . . . . . . . . . . . . . . . . . . . . . . . . . . .

c. Yegua clays: Dark-blue gypseous clays and dark bluish-gray sands with considerable deposits of lignite . ..................

d. Upper marine beds or Cooks Mountain beds: A series of greensands, fossiliferous greensands, fossiliferous clays, stratified black and gray sandy clays, black and yellow clays with limy concretions. A very prolific Claiborne fauna $\ldots . . . . . . . .$.

e. Mount Selman beds: Brown sands, blue clays, greensands, glauconitic sandstone, and heavy deposits of limonite. More or less fossiliferous, but fauma mostly represented by casts .. -

f. Lignitic: White, yellow, gray-brown, red, blue, and black sands with interstratified and interlaminated blue, gray, and brown clays with heavy beds of lignite. Apparently unfossiliferous except for a few plant remains, including the palmetto......

g. Wills Point clays: Yellowish-brown sands containing bowlders of sandstone and limestone with some calcite concretions; dark-blue and brown laminated and massive clays and fossilif-

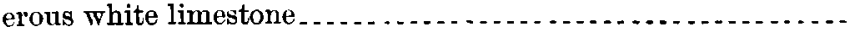




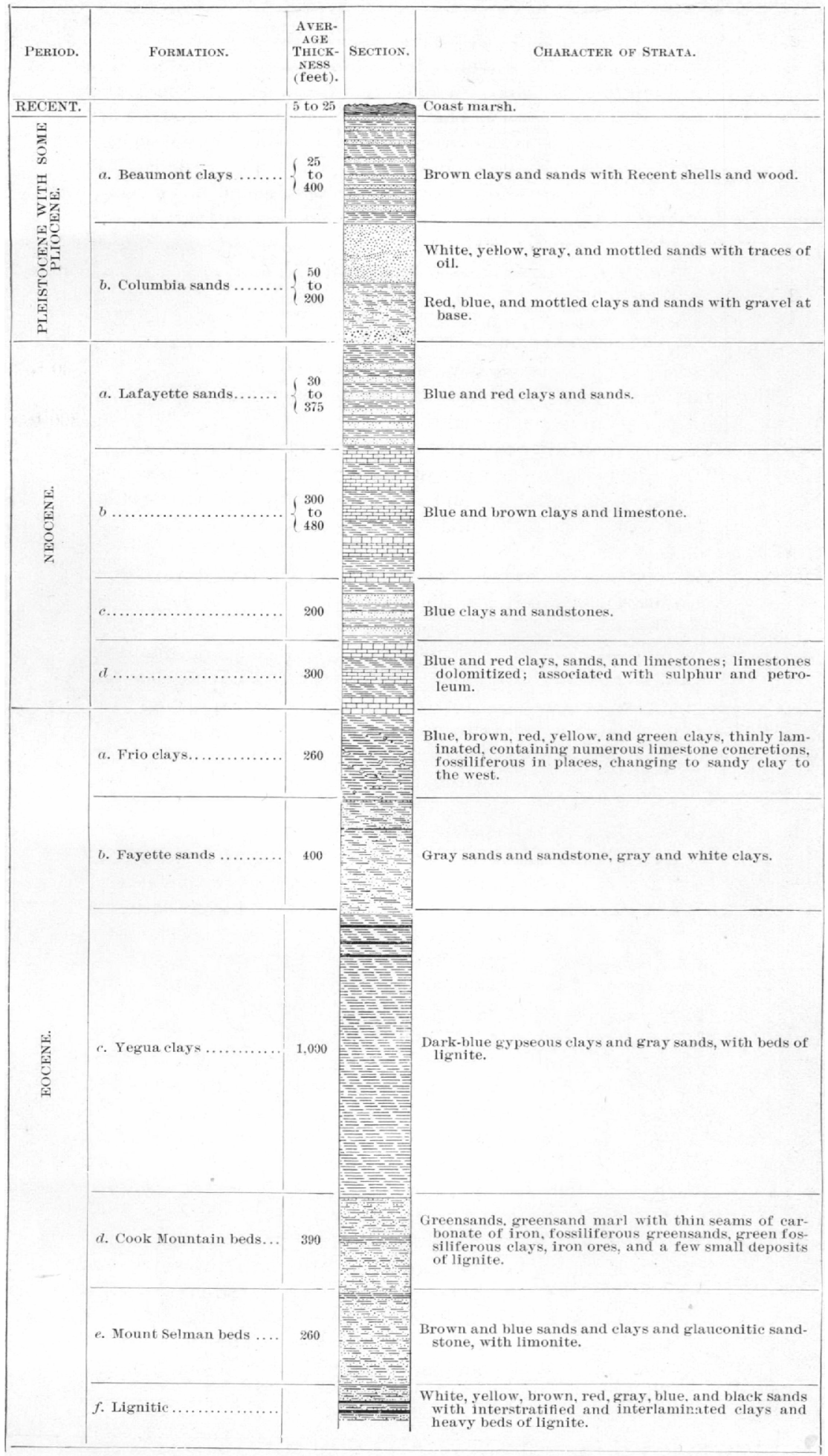



So far as the coastal formations are involved it is unnecessary for present purposes to go below the Fayette sauds, as their outcrops form the northern limit of the Gulf Coastal Plain. In some localities it may not be necessary to go below the Frio clays. 'These clays in point of time are, so far as known, the last division of the Eocene in Texas. Owing to the overlapping of newer deposits and extensive erosion which has frequently completely cut throngh and removed portions of these Frio clays, great uncertainty exists in relation to this point, and it has been deemed best to assume the Fayette sands as the base (or rather as lying immediately below the base) of the coastal formations.

FAYETTE SANDS.

Fayette sands are sandstones and clays with occasional small irregular deposits of limestone carrying Iower (laiborne fossils, and sands containing imprints of leaves. 'The limestones are not of frequent occurrence.

'The Fayette sands were considered Grand Gulf by IIilgard, IIopkins, and Loughridge. Hilgard considered these and the next succeeling clays to be the equivalent of his Mississippi beds. Penrose included them with the underlying Yegua clays and overlying Frio clays as the Fayette beds, and as such they are described in the early reports of the Texas geological survey.

The structural difference between the underlying clays and the sandstone group led to a separation and the placing of the clays at the base of the Fayette beds under the title of Yegua clays. The Frio clays were afterwards assigned to a separate division and the name Fayette was retained for the middle division of sandstones and clays.

It is with these Fayette sands in their restricted definition that we have to deal. These beds form a well-marked horizon from the Mississippi River westward through Louisiana and Texas past the Rio Grande into Mexico.

On their northern side they show abrupt faces in numerous localities, indicating extensive erosion. When seen to the south they apparently slope off gently at a dip of only a few feet per mile. This dip is such that if the beds continued with uniform composition they should be found in the wells at Spindletop at depths not exceeding 1,200 to 1,500 feet. They do not occur in these wells, however, and it may be inferred that considerable erosion has taken place along their southern margin as well as on the northern side. That these sandstones formed the shore line for some time is evident, not only in the eastern division of the Coastal Plain, but also farther west, where the sandstones and the later deposits can be seen abutting against each other in such a manner as to indicate that the sands formed a steep shore line when the later deposits were laid down. 
The rapid changes of texture of these beds from sands to sandstones and again to sands may account for the difficulty of recognizing the Fayette sands in the boring of the wells around Spindletop, and it is possible, though improbable, that some of the thin-bedded irregularly deposited sandstones reported belong to these beds.

In connection with the Fayette sands a comparatively heavy bed of thinly laminated brown and gray clays, carrying considerable quantities of iron pyrites, is often found, and a considerable amount of sulphur is disseminated throngh them. These clays first make their appearance on the Brazos River, and occur on the Colorado and on Elm Creek near Muldoon in Fayette County. 'They also occur in Starr County on the Rio Graude. They do not appear on the Trinity, and their extent east of the Brazos is unknown, as no exposures are found. They appear to lie in a long, narrow trough and to be from 10 to 50 feet in thickness. In Fayette County they are associated with small quantities of petroleum, and it is possible that they are the source of the small seeps of oil found in the overlying sandstones in Waller County.

\section{FRIO CLAYS.}

The geologic horizon of the succeeding Frio clays ${ }^{a}$ is not so clear as in the case of the Fayetite sands, on acrount of the enormous amount of erosion that must have taken place between their deposition and that of the next succeeding formation, and on account of the great extent to which the Frio clays are overlapper by later formations.

The character of the Frio clays is more persistent than that of the Fayette. A heavy deposit of blue clay with its conspicuous line of calcareous nodules forms a horizon as prominent and well marked as the most continuous ledge of sandstone in the Fayette. The other clays of the Frio are not so uniform either in thickness, texture, or continuity. While they generally contain carbonate of lime, at some places this lime is replaced by gypsum, and the clays themselves by sands. The Frio beds appear to have been found in the Federal Crude well at Beaumont at a depth of 2,300 feet. From the nearest outerops of these clays to the well the distance is about 75 miles. This would give the beds an approximate dip of 35 feet per unile. 'The Frio clays have not as yet been recognized in the logs of any wells producing petroleum. From west to east the Frio clays change considerably in

a In the Third Annual Report of the Texas geological survey the Frio clays were described under the name of the Fleming beds. Later, Dumble, working on the Frio River, found the same beds well developed and suggested the name Frio clays, which was adopted, and these clays have been known as Frio clays ever since. Quite recently Mr. A. C. Veatch examined the same clays in the ricinity of Burkeville, Newton County, Tex., and in his report suggests the name "Burkeville beds" for them. The writer, having examined the whole series from their exposures on the Frio River eastward through Texas, including the exposures at Fleming, near Jasper and Burkeville, and across the Sabine as far as the line of the Kansas City Southern Railway in Louisiana, and finding these clays the same in each place, considers that the name Frio clays should be retained, and that it is unnecessary to introduce the name "Burkeville beds, " at least into the nomenclature of the Texas areas.-W. C. 
composition and texture. The beds as exposed along the Frio River are a series of gypseous clays with sand and sand rock. " Between the Brazos and Trinity rivers the beds are grayish sandy clays with nodular concretions of lime and occasional deposits of gypsum erystals, thin sfrata of sandstone, and bluish-gray sands containing nodules of lime and clay. East of the Trinity the calcareous clay beds become predominant and the sandstones are never very strongly represented, losing their continuity of stratification and appearing simply as large concretions or bowlders. Another peculiarity in the Frio beds, which appear's more prominently in the eastern division than in the other sections, is that when they are thin bedded the calcareous concretions are largely replaced by crystals of gypsum, while where they are thick bedded gypsum crystals do not occur and calcareous , concretions are found exclusively.

There has been considerable disagreement as to the age of these clays. Hilgard, Hopkins, and Loughridge assigned them to the Grand Gulf and considered them as of Miocene age, and lately Iarris has been inclined to consider them as Grand Gulf but belonging to the Oligocene. The Texas geological survey held them to be of Eocene age and placed them at the top of the Eocene column. They have been assigned to that portion on account of their containing fauna which appears to be distinctly of Eocene age.

\section{BURIED BEDS.}

The next succeeding beds do not outcrop, and their existence has been demonstrated by drilling. These are the beds marked b, c, and $d$ in the general section (p. 20). The uppermost of these divisions, $b$, has a thickness of from 300 to 480 feet, and consists of a series of blue, brown, and gray clays with thin beds of limestone. The second division, c, has a thickness of 200 feet, and is chiefly blue clay with thin-bedded sandstones. The third division, $d$, comprises blue, red, and gray clays and sand carrying Miocene fossils " and thin-bedcled limestones, with a fair proportion of the limestones changed to dolomite, and is associated with beds of sulphur and coarse sands carrying sulphur crystals and beds of pyrites. This division las a thickness of 300 feet. It appears to be the chief source of the petroleum and gas found on Spindletop and also the source of the petroleum found in the other producing fields. The Sour Lake, Saratoga, and Jennings fields, however, obtain their flow from the associated gray sands instead of limestone or dolomite. Division b also carries small quantities of petrolenm and gas, but the blue clays and sandstones appear to be barren.

These beds have been variously assigned to the Cretaceous and Tertiary. Professor Harris ${ }^{c}$ places them in the Cretaceous on account 
of their association with gypsum and sulphur and their somewhat vague analogy with the deposits of sulphur and petroleum at Sulphur Mine, Louisiana. The latter deposits were regarded as Cretaceous by Hilgard in 1871, and have since been so considered without any very conclusive evidence. Harris assumed the presence of an. anticline of sufficient elevation to bring the Cretaceous several thousand feet above its normal position. II is assumption of an anticline is correct, but it was formed after the Eocene had been laid down, and consequently several thousand feet of beds of that age intervene between the Cretaceous and the oil-producing beds. Hill places these beds in the Neocene, but states that they might as well be placed in the Pleistocene, or Recent, or anywhere else, as Neocene really means nothing in particular beyond the fact that such beds are considered postEocene. ${ }^{a}$

On the other hand, Prof. Gilbert Van Ingen, of Columbia Univesity, who examined the material from the Iucas well, reports it to be a compact quartz sandstone, with grains of round to crystalline pellucid quartz. The fossils are in layers, the oyster shells having been apparently washed into their present position by wave action. The interspaces between the oyster shells are occupied by less compact sand, full of lamellibranch shells. These are seldom perfect, and on the whole the material is so fragmentary that identification of the species is very difficult or impossible. They are clearly Tertiary, but whether Eocene or Miocene does not clearly appear. Professor Van Ingen's list comprises Ostrea sp., Turritella sp., and Mactra sp. ${ }^{b}$ These were all he could make out.

It is noticed that Professor Van Ingen is doubtful as to whether these petroleum-bearing beds are Eocene or Miocene. Dr. W. H. Dall examined material found in various wells in the vicinity of Beaumont and placed all the shells examined by him in the Miocene. The specimens examined were from the Island well at a depth of 800 feet, the Bayou City well between 1,875 and 1,910 feet, and the Texas Oil and Pipe Line Company's well between 940 and 1,036 feet. The material from this last well was the actual oil-bearing rock and the source of supply for that well. The other two wells are not on Spindletop and are dry. The fossils from the Island well are Natica tuomeyi Whitfield var. Crassinella, sp. like galvestonensis Harris, and Corbula (fragment). From the Bayou City well the shells were badly broken and show small Mulinia, Balanus sp. (fragments), and the earbone of small fish. Of these Dr. Dall says: "These Bayou City fossils are uncharacteristic, but with very little doubt belong to the Miocene similar to that penetrated at about the same depth by the artesian well at Galveston some years since." In the Texas Oil and Pipe Line well the rock is described as a hard gray marl with water-worn oysters like $O$. virginica and probably Miocene. 
Mr. T. H. Aldrich, ${ }^{a}$ of Birmingham, Ala., on the evidence of some shells from a depth of 390 feet, assigns these petroleum beds to the Pliocene, saying, "Your fossils are very interesting, and confirm our previous theory that the formation that lies above the oil-bearing stratum around Beaumont is Pliocene, or even later." The specimens described by Mr. Aldrich were Nassa beaumontensis n. sp. Aldrich, Tornatina canaliculata Say, Turbonilla sp., and a young Mactra. Mr. Aldrich's determination of the oil-bearing deposits is not conclusive, as at least 600 feet of clays, limestones, and sandstones intervene between his fossil beds and the oil-producing strata. As the evidence goes, therefore, it points strongly to the conclusion that the age of these petroleum beds is Miocene.

A rough section showing the position of these beds may be constructed from their contained fauna, but it must be borne in mind that the depths and thicknesses shown by particular wells vary from those shown in other wells either in the vicinity of Spindletop or at several miles distance. With the exception of those found at 40 feet, the shells are from wells on Spindletop or in the immediate vicinity.

Section constructed chiefly by means of fossils obtained from wells in the Beaumont district.

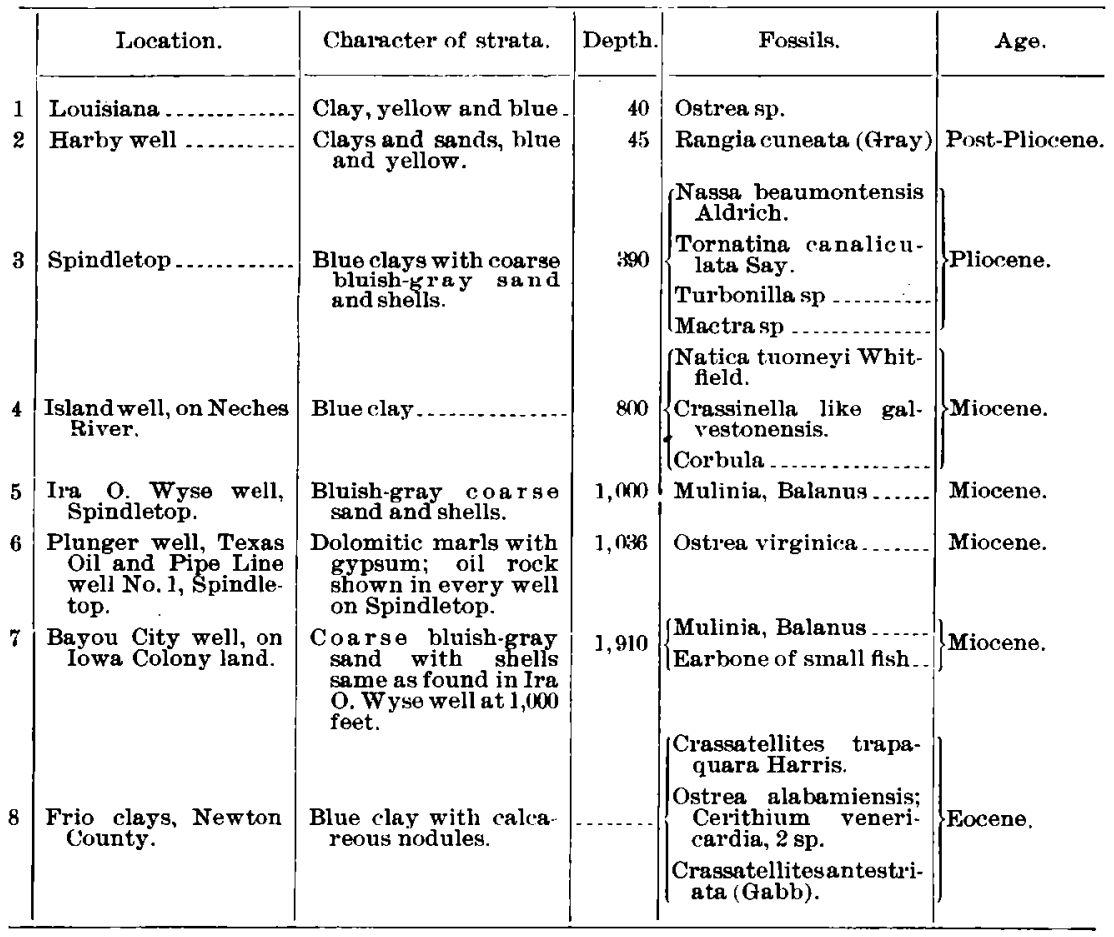

Nos. 4, 5, 6, and 7 belong to the Miocene and are the divisions marked b, c, and $d$ in the general section given on page 20 . 
The beds overlying these oil-bearing sands, clays, and limestones comprise a series of blue and red thinly laminated and massive red and brown clays and cross-bedded sands and gravels having a thickness of from 30 to 375 feet. They are probably the eastern extension of Dumble's Oakville beds of the western division, as they occupy a closely analogous position.

These beds come to the surface and spread over a wide belt to the north, overlapping and completely obscuring the petrolenm-bearing beds. In many places they even overlie and obscure the Frio clays, and are found resting directly upon the Fayette sands. These beds are widely distributed throughout the Coastal Plain and may probably be safely correlated with McGee's Lafayette. They have a comparatively gentle dip compared with that of the underlying Frio clays or Fayette sands.

From the general structure of the country it seems that at the close of the Eocene the Frio clays were raised and tilted seaward slightly, remaining above water during the deposition of the limestones, sandstones, and clays forming the petroleum-bearing beds. These latter were evidently laid down over a sea floor which was being tilted southward until the last of the petroleum clays, and possibly also some of the succeeding red and brown clays of the Iafayette, had been deposited.

This tilting movement ceased soon after the beginning of deposition of the I afayette, and the land began to sink again. The Lafayette sea encroached upon the shores and gradually overran the petroleumbearing beds, depositing sandstones and limestones, and even covered a considerable area occupied by the Frio clays and Fayette sands. With another change of movement these red and brown elays and gravels were in a large measure reworked, probably while above sea level, and the finer clays and sands were washed into deeper water. The coarser material was left by the retiring sea, and now forms the extensive deposits of gravel.

The age of these sands and clays has not yet been satisfactorily determined. It is probable that they are in part Miocene and in part of later age. They are here assigned to the Miocene, upon the general assumption that they are younger than the Eocene and aven the oil-bearing beds, but older than any of the Pleistocene deposits. 'They may possibly belong to the Pliocene, although we have no proof of this. They do not appear to be fossiliferous. Some of the gravels contain fossils, but these fossils belong to the original formations. from which the pebbles were derived.

COLUMBIA SANDS.

Overlying the Iafayette beds there is a heavy deposit of gravel, the age of which has not yet been definitely determined. By some it has 
been considered as the upper member of the preceding sands and elays, and is therefore placed with the Lafayette. These gravels have evidently been derived from the Lafayette, by a process of assorting and rearranging, at a time when the sand beds of this age overspread the greater portion of this region. They are made up chiefly of chert, quartz, agate, jasper, and some crystalline rocks, of which only the quartz and crystalline pebbles bear evidence of having traveled very far. The chert is peculiar in its angular and subangular condition. These gravel bels are more extensive toward the Mississippi Valley region than to the west in Texas, where they appear to gradually thin out.

These gravels have been here considered as forming the basal member of the gray sands, clays, and gravels which, with their overlying heavy beds of yellow, blue, brown, and black calcareous clays and brown and gray sands, form what MeGee calls the Columbia and the deposits of clays and sands long ago denominated by Hilgard the Port Hudson clays. This brings them within the Pleistocene. They appear in many of the wells to have a thickness of from 50 to 250 feet, or even more.

\section{BEAUMONT CLAYS.}

Overlying the Columbia as above defined is a series of yellow, gray, blue, brown, and black clays with brown sands. These beds are sometimes thinly stratified or laminated, but frequently massive. The laminated beds are usually interstratified with thin beds of blue and gray or grayish-white sand. The clays carry considerable quantities of calcareous nodules irregularly distributed, in many places shells of Pleistocene or Recent age, and great quantities of decaying wood in the form of tree trunks, bark, and leaves. Among these the cypress appears as the most prominent, and among the invertebrate fauna found the Rangia cuneata (Gray) and an undetermined oyster are the prevailing forms.

In Texas the prevailing colors of these clays are blue, yellow, and brown; in Louisiana are occasional deposits of jed clay. In many features the blue clays of these Beaumont beds strongly resemble the blue Frio clays, and, from the generally low dip of the beds throughout the regions occupied by both and the known existence of small flexures or shallow undulations, might be erroneously correlated with these underlying Frio beds. The chief differences between them, apart from their geologic position, appear to be the presence of wood in the Beaumont beds and the condition of the calcareous nodules. In the Frio clays these nodules appear to have a definite horizon and to lie in a more or less stratified condition, to have regular lines, and to be continuous with the blue clay. Although in several regions replaced by gypsum crystals, they continue in the regular lineal arrangement. In the Beaumont beds these nodules do not appear to 
have any definite position among the clays. It is true that they always accompany the blue clays, but they are always found scattered in small pockets and occupying irregular patches a few acres in extent. It is possible that by some chemical action during or after the deposition of the clays the lime had been segregated into small depressions or softer portions of the clays.

The country occupied by these clays is flat and, as a general thing, poorly drained. As a result the greater portion is unforestel. Occasional mottes of small trees appear scattered over the prairie, and straggling lines of timber are found along the banks of the water courses. Owing to these conditions very little knowledge of the structure can be obtained from the surface; nowhere do we find sections exposing more than a few feet, and these show only the prevailing bed of clay. Knowledge of the structure of this area can be gained only from the records of the various wells. Along the Neches in the vicinity of Beaumont and on Pine Island Bayou a few natural sections occur. At Beaumont the beds are seen to be laminated blue elays with brown partings, and on Pine Island a small section of blue and yellow clays is shown.

This series of clays and sands has been named the Beaumont beds, from its greatest development in the neighborhood of that city, sections showing as much as 400 feet having been obtained from many of the wells. The greatest areal extent of these beds is found between the Trinity and the Sabine rivers in Texas, where the maximum width, north and south, is a little over 20 miles. To the east of the Neches River their outcrops narrow rapidly, forming but a narrow strip across Orange County. In the Louisiana regions they appear to widen again to a considerable extent. These clays occur at Lake Charles and extend eastward in a broad belt to Abbeville, in Vermilion Parish. Passing westward from Beaumont, the areal extent of these clays decreases gradually to a few miles, and though they have been traced as far west as the Guadalupe River, in Calhoun County, they do not appear to again widen greatly, though their chief characteristics remain constant. The Beaumont beds can usually be detected by the peculiar nature of their soil, which is in many places highly calcareous, while the accompanying clays are black, owing to the mixture of lime and the decaying vegetable matter contained in the clay.

The well sections given on pages 132 and 136 show the relations of these clays to the underlying clays in the Louisiana parishes, and the records given of deep wells in the oil-producing areas show their connection in Texas.

Large tracts where the Beaumont clay is exposed lie in very nearly the same marshy condition as the coastal marsh country itself. In some areas the surface blue and yellow clays form a low bluff or ridge, separating the two divisions. This is more noticeable in the Louisiana regions than in Texas. 
Throughout the Beaumont clay region large numbers of peculiar mounds or hillocks occur, forming the often-described "pimpled plains." These mounds extend. in a few cases, within the limits of the coastal marshes.

\section{RECENT OR PORT HUDSON CLAYS.}

The recent Beaumont clays are overlain by very recent materials, the present river alluvium and the coast marshes. The first river bottom or alluvium proper fringes all the rivers in the Coastal Plain, whether they originate in or pass through the plain. No average width can be assigned to these deposits, as the low bluffs following the margins of the river valley may open out for several miles and again close within the distance of a mile so as to restrict the river to its actual water channel and efface the bottom land or newer alluvium altogether. If the lands subject to overflow be considered the representative of the very recent deposits, these will range from a half mile to 5 miles in width along each side of the river. Along the Sabine the Fayette and Frio clays are exposed at many places in the form of high bluffs. On the Trinity the overflow lands have widths of from 3 to 5 miles, and the Blazos bottoms at several points and at certain seasons present the appearance of a river from 12 to 25 miles in width. In thickness these deposits range from 4 to 25 feet.

The coast marshes are restricted to the southeastern portion of Texas and southern Louisiaua, not existing west of Galveston Bay. These marshes inchude a broad belt, but little elevated above sea level, extending from Galveston Bay eastward through Texas and southern Louisiana as far as the eastern side of Vermilion Parish. The northern border of this belt is extremely. irregular, and in many places tongues of the underlying clays extend for several miles, forming ridges and islands, as these elevations are called. The plain is covered with a heavy growth of marsh grass, and with reeds and other vegetation where water forms the permanent covering. Thronghout the most southerly portion there are numerous sink holes or floating marshes, absolutely impassable for man or beast.

In these coastal marshes a few sluggish bayous are found. They have apparently little or no current, and are more or less affected by tidal influences. Of these the most important in Texas are East Bayou and Mud Bayou in Chambers and Galveston counties, and Taylors Bayou and Hildebrands Bayou in Jefferson County. In Louisiana the bayous are few in number, but those which occur have expanded to broad sheets of water, such as Calcasieu, Grand, and Mud lakes.

At several points along these bayous the banks form small bluffs, ranging from 2 or 3 feet to 20 and sometimes more feet. These bluffs are generally made up of shells of Gnathadon cuneatus, with a few species of oyster. Probably the most prominent of these is Grigsbys Bluff on the Neches, Shell Bluff near the mouth of the 
Sabine, and the low bluffs along Black Jake near Hackberry Island in Cameron Parish, La.

Between the coastal marshes and the Gulf there is a narrow, newly formed strip of sand, with considerable quantities of recent shells. This strip appears to form a barrier between the Gulf waters and the marsh, and is in most localities elevated a few feet above the marsh.

\section{DETAILED SECTIONS OF COASTAL PLAIN FORMATIONS.}

The foregoing greneralized deseription of the formations of the Gulf Coastal Plain will give most readers a sufficiently complete idea of their character and thickness. For the oil prospector, however, local details are important, and these are therefore given in the following pages. There is necessarily some repetition of what has gone before, since the generalized section is largely based upon these special sections. The eastern division of the Gulf Coastal Plain as above defined will be described from its western end eastward.

\section{DETAILED SECTIONS ON THE GUADALUPE.}

The detailed geology of the western end of this eastern division of the Gulf Coastal Plain is not well known. South of the outcrops of gray sandstones of the Fayette beds the country is mostly prairie, and the surface, as east of the Brazos, is made up of clays and sands. Very few well records are available, and consequently very little knowledge of the underground formations is obtainable. Along the Guadalupe River the banks are mostly obscured by deposits of recent material, and the few sections seen are referable more to the Fayette sands than to the Coastal Plain formations.

Throughout this region the ridges forming the northern boundary of the plain may be placed in part with the Fayette sands and in part with the succeding Frio clays, and way be roughly characterized as follows:

\section{General section near the Guadalupe.}

1. Ferruginous gravel containing pebbles of quartz, jasper, carnelian, and chalcedony.

2. Conglomerate formed from underside of gravel beds. The cementing material is calcareous and the conglomerate is only found where the white or gray sands prevail.

3. Brown to red clays and sands, more or less mixed with pebbles, occasionally indurated and showing considerable ledges of red or brown sandstone in places.

4. Bluish-gray to gray or dirty white sands, more or less calcareous; and limy clays of blue or grayish-blue color.

5. Thin-bedded, soft, grayish, calcareous sandstones, changing frequently into gray calcareous sands.

6. Red and blue mottled sands.

No. 4 of this section belongs to the Frio clays, or to that phase of those beds peculiar to this section of the country. With but slight 
local variations these beds may be traced eastward as far as the western edge of Montgomery County.

No. $\tilde{5}$ is the uppermost member of the Fayette sands and appears to have the same characteristics wherever found. It, therefore, is a good guide across the country separating the underlying Fayette sands, clays, and sandstones from the overlying Frio clays.

Surface sections showing the relations of the beds are few. A section at Buchel's dam on the Guadalupe River, in Dewitt County, is as follows:

Section at Buchel's dam on Guadalupe River.

1. Gray sandy soil

Feet.

2. Black subsoil

1

3. White gravel

4. Hard, brown sandstone

5. Thin beds of sandstone with clay partings to water 8

Four miles farther down the river the soft, white, calcareous sandstones of No. 5 of this section outcrop, and form the capping of the second bottom lands, being here directly overlain by brown sands and brown gravel.

Throughout the eastern portion of Dewitt County the ridge shows the same general structure, with the exception that in the Chicoleet country and eastward in the neighborhood of Perryville the brown and red sands and gravels are in great measure replaced by beds of light-colored (almost white) gravel and beds of heavy, white, calcareous conglomerate.

On Irish Creek, on the $\boldsymbol{\Lambda}$. Biddy league, ${ }^{a}$ a section is as follows:

\section{Section on Irish Creek.}

1. Black soil

2. Soft white limestone or calcareous sandstone $\ldots \ldots \ldots \ldots \ldots \ldots \ldots \ldots$

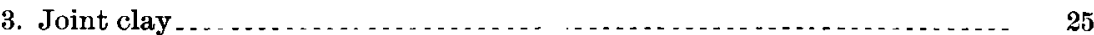

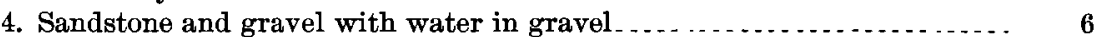

Still farther east, on the North Chicoleet, the following section is shown:

\section{Section on the North Chicoleet.}

Feet.

1. Gray soil _...

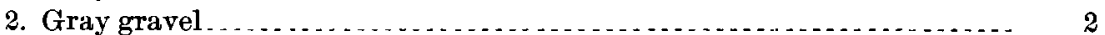

3. Coarse gray sandstone $\ldots \ldots \ldots \ldots \ldots$

The gray conglomerate appears throughout this region in association with the gray gravels; in fact, the one appears to be complementary to the other.

Lying along the southern side of the ridge are more or less distinct deposits of brown and gray sandstones. These appear broken or in

"The league is still used in Texas for lands surveyed during Mexican possession. It contains 4,428.4 acres. 
a bowlder-like form. From these beds the country slopes very gently until it merges into the grent Coastal Plain proper. Very few sections are obtainable within the limits of the plain, but from the shallow cuttings seen in this section the underlying beds appear to be blue limy clays. About 3 miles south of Port Lavaca, in Calhoun County, on Chocolate Bayou, a cutting along the bank is as follows:

Section on Chocolate Bayou, 3 miles south of Port Lavaca.

1. Black soil



3. Gray calcareous clay, in places blue with limy nodtles.............. 0 to 5



These gray calcareous clays, or their blue phase, outcrop in a belt stretching across the country as far east as the Sabine River and probably much farther. The clays with their calcareous concretions have been recognized in Wharton and Brazoria counties, in the neighborhood of Houston and Beaumont, and near Orange, in Orange County. They also appear in Isouisiana.

\section{DETAILED SECTIONS ON THE COLORADO AND BRAZOS.}

Eastward through the counties of Jackson, Matagorda, Wharton, Brazoria, Fort Bend, Colorado, and Austin the country presents the general appearance characteristic of the Coastal Plain. In Colorado and Austin counties the Fayette sands with their overlying Frio clays are fairly well developed. In the middle and southern portions of Austin County the Fayette beds, in the form of coarse calcareous sandstones, are found underlying the Frio clays, which in this locality are bluish-gray limy clays, with the limy concretions broken and powdery where exposed. Gray calcareous sandstones appear in the banks of the Brazos at Cochran's ferry, near Buckhorn post-office, in Austin County, underlying the grayish-blue calcareous Frio clays. Throughout the same area many of the higher grounds are occupied by ferruginous and gray gravels. At Seely, in Austin County, the Frio clays are comparatively thin, being only 35 to 40 feet in thickness, and overlie the upper sandstones of the Fayette.

In the neighborhood of Richmond and Rosenberg, in Fort Bend County, the coastal deposits comprise a series of dark-brown to black calcareous clays, more or less intermixed with deposits of sand. No surface sections are visible, and in the vicinity of the Brazos River the recent alluvium is so heavy that no reliable sections are to be found. Occasional low bluffs showing interstratified blue clays and sands occur, but these give no distinctive indications to their age. The dip of these beds is apparently to the east of south, but the exposures are in such condition that no great reliance can be placed upon them.

The only wells drilled to any depth in this portion of the country 
are those at the Victoria Ice, Light, and Power plant, at Victoria, in Victoria County, and a prospecting well at O'Connorsport, on the shore of Matagorda Bay, in Calhoun County. Shallow wells for water are numerous, but no sections of these are available. They generally do not exceed 100 feet in depth and are mostly operated by windmill. Artesian water has been obtained at depths ranging from 400 to 600 feet. In most of these deep wells, however, the water is brackish. The drillers state that the water is usually found in a coarse sand or fine gravel, which may possibly be No. 3 of the Victoria section.

The section shown by the well at Victoria has been supplied by Mr. Heaton, who kept the records and a complete set of samples of the borings as far as possible.

Log of well at Victoria, Victoria County, Tex.

\begin{tabular}{|c|c|c|c|c|}
\hline & Character of strata. & Thickness. & From- & To- \\
\hline 1 & Surface sands and clays & $\begin{array}{l}\text { Feet. } \\
\quad 40\end{array}$ & $\begin{array}{l}\text { Feet. } \\
\\
\end{array}$ & $\begin{array}{l}\text { Feet. } \\
\quad 40\end{array}$ \\
\hline 2 & Heavy gravel .. & 32 & 40 & 72 \\
\hline 3 & Gray sand . & 10 & 72 & 82 \\
\hline 4 & Pale-blue clay $\ldots$ & 16 & 82 & 98 \\
\hline 5 & Gray sand. & 12 & 98 & 110 \\
\hline 6 & Calcareous pale-blue clay & 43 & 110 & 153 \\
\hline 7 & Gray sand $\ldots$ & 60 & 153 & 213 \\
\hline 8 & Light-gray sand & 50 & 213 & 263 \\
\hline 9 & Pinkish-gray clay . . & 41 & 263 & 304 \\
\hline 10 & Pale-brown clay . . . . . . & 100 & 304 & 404 \\
\hline 11 & Gray sand $\ldots$ & 22 & 404 & 426 \\
\hline 12 & Fine grayish-brown sand. & 30 & 426 & 456 \\
\hline 13 & White calcareous clay & 40 & 456 & 496 \\
\hline 14 & Said to be red clay; sample wanting ... & 255 & 496 & 751 \\
\hline 15 & Fine gravel and sand & 1 & 751 & 752 \\
\hline 16 & Gray sand . . . . . . . . & 43 & 752 & 795 \\
\hline 17 & Red sand with a little soil & 8 & 795 & 803 \\
\hline 18 & Red sand ... . & 87 & 803 & 890 \\
\hline 19 & Red clay . . . . . . . & 4 & 890 & 894 \\
\hline 20 & Gravel in brown sand & 1 & 894 & 895 \\
\hline 21 & Fine brown sand & 57 & 895 & 952 \\
\hline 22 & Fine gravel & 1 & 952 & 953 \\
\hline 23 & Red sand $\ldots \ldots$ & $\cdots$ & 953 & - . \\
\hline
\end{tabular}

Bull. 212-03 -3 
Forty miles farther south, on the shore at O'Connorsport, a well drilled in prospecting for oil shows the following section:

Log of well at $O^{\prime}$ Connorsport, Calhoun County, Tex.

\begin{tabular}{|c|c|c|c|c|}
\hline & Character of strata. & Thickness. & From- & To- \\
\hline 1 & Black sandy soil & $\begin{array}{l}\text { Feet. } \\
\\
\end{array}$ & $\begin{array}{l}\text { Feet. } \\
\\
0\end{array}$ & Feet. \\
\hline 2 & Fine shells and sand . . . . & 35 & 3 & 38 \\
\hline 3 & Yellow quicksand . - & 87 & 38 & 125 \\
\hline 4 & Coarse sand $\ldots \ldots \ldots$ & 35 & 125 & 160 \\
\hline 5 & Coarse variegated sand .... & 35 & 160 & 195 \\
\hline 6 & Finer variegated sand & 30 & 195 & 225 \\
\hline 7 & Fine black quicksand & 85 & 225) & 310 \\
\hline 8 & Sand and fine shells with artesian water. & 60 & 310 & 370 \\
\hline 9 & Yellow clay and sand with traces of oil $\ldots$ & 7 & 370 & 377 \\
\hline 10 & Blue clay ......... & 52 & 377 & 429 \\
\hline 11 & Yellow sand rock. . & 1 & 429 & 430 \\
\hline 12 & Blue clay $\ldots \ldots \ldots$ & 15 & 430 & 445 \\
\hline 13 & Round sand and fine shells, strong artesian flow & 45 & 445 & 490 \\
\hline 14 & Rock . - & 4 & 490 & 494 \\
\hline
\end{tabular}

This well is located within half a mile of the western shore of Matagorda Bay and not more than 10 feet above sea level.

Well No. 2 of the O'Connorsport Mining Company has been drilled to a depth of 1,484 feet. The following is the log of uhis well as supplied by the drillers:

Log of well No. \& of the O'Connorsport Mining Company, O'Connorsport, Calhoun County, Tex.

\begin{tabular}{|c|c|c|c|c|}
\hline & Character of strata. & Thickness. & From - & To- \\
\hline 1 & Soil & $\begin{aligned} \text { Feet. } & \\
& 3\end{aligned}$ & $\begin{array}{l}\text { Feet. } \\
\\
\end{array}$ & $\begin{array}{l}\text { Feet. } \\
\end{array}$ \\
\hline 2 & Fine white quicksand & 18 & 3 & 21 \\
\hline 3 & White and chocolate clay... & 22 & 21 & 43 \\
\hline 4 & Greenish clay with shells & 37 & 43 & 80 \\
\hline 5 & Gray sand . ..... & 3 & 80 & 83 \\
\hline 6 & Hard yellowish clay .... & 77 & 83 & 160 \\
\hline 7 & Coarse shells and sand & 6 & 160 & 166 \\
\hline 8 & Hard clay and shells...... & 44 & 166 & 210 \\
\hline 9 & Sand . . & 15 & 210 & 225 \\
\hline 10 & Hard clay and oyster shells & 95 & 225 & 320 \\
\hline 11 & Round sand and fine shells, artesian flow & 45 & 320 & 365 \\
\hline 12 & Blue clay with some shells $\ldots \ldots \ldots \ldots \ldots$ & 87 & 365 & 452 \\
\hline 13 & Coarse gray sand and shells, artesian flow & 24 & 452 & 476 \\
\hline
\end{tabular}


Log of well No. 2 of the O'Connorsport Mining Company, etc.-Continued.

\begin{tabular}{|c|c|c|c|c|}
\hline & Character of strata. & Thickness. & From- & To-- \\
\hline & & Feet. & Feet. & Feet. \\
\hline 14 & Conglomerate & 75 & 476 & 551 \\
\hline 15 & Gray sand. . & 16 & 551 & 567 \\
\hline 16 & Conglomerate and blue clay mixed . & 127 & 567 & 694 \\
\hline 17 & Gray sand with traces of oil & 10 & 694 & 704 \\
\hline 18 & Hard rock & 3 & 704 & 707 \\
\hline 19 & Light sand with traces of oil. & 3 & 707 & 710 \\
\hline 20 & Blue clay $\ldots . . .$. & 3 & 710 & 713 \\
\hline 21 & Hard rock with soft layers. & 12 & 713 & 725 \\
\hline 22 & Gray sand with shells & 42 & 725 & 767 \\
\hline 23 & Shell concrete . . . . . & 120 & 767 & 887 \\
\hline 24 & Sand; artesian water and oil flowed & 25 & 887 & 912 \\
\hline 25 & Concrete with bowlders & 4 & 912 & 916 \\
\hline 26 & Gray sand ................. & 36 & 916 & 942 \\
\hline 27 & Blue clay with shells and bowlders & 66 & 942 & 1,008 \\
\hline 28 & Light-colored clay and very fine sand & 14 & 1,008 & 1,022 \\
\hline 29 & Blue clay ..... & 17 & 1,022 & 1,039 \\
\hline 30 & Rock . . . . . . & 3 & 1,039 & 1,042 \\
\hline 31 & Blue clay, bowlders, and shells & 9 & 1,042 & 1,051 \\
\hline 32 & White sand; traces of oil ... & 1 & 1,051 & 1,052 \\
\hline 33 & Blue clay, hard in places & 4 & 1,052 & 1,056 \\
\hline 34 & Light-colored clay and rock. & 31 & 1,056 & 1,087 \\
\hline 35 & White water-bearing sand .... & 10 & 1,087 & 1,097 \\
\hline 36 & Red and blue clay $\ldots \ldots \ldots$ & 133 & 1,097 & 1,230 \\
\hline 37 & Light-colored clay with red specks. . . & 232 & 1,230 & 1,562 \\
\hline 38 & Red, white, and blue variegated clay $\ldots \ldots \ldots$ & 22 & 1,462 & 1,484 \\
\hline
\end{tabular}

Apparently No. 27 of this section agrees with No. 6 of the Victoria section and both may be regarded as Frio clays. This would grive these clays a dip of 20 feet per mile in this region.

This well is drilled about half a mile from the shore of Matagorda Bay and 3 miles southeast of the old town of Indianola.

Within this area four of the small elevated areas occur. These are Big Hill, in Matagorda County; Bryan Heights, near Velasco; Kiser Heights, at Columbia, and Damon Mound, near the northern side of Brazoria County. The first two are comparatively low, and might probably be overlooked by the traveler. Damon Mound (see fig. 1), however, is a very prominent feature. Situated on the northern side of Brazoria County, on the Darst league, it forms a very prominent feature in the landscape. For at least 20 miles in any direction the surrounding country is a low, level prairie. The mound itself rises somewhat abruptly to an approximate height of 83 feet 
above the general level of the surrounding prairie and about 140 feet above sea level.

The approximate area of this mound is 2,500 to 3,000 acres, having a somewhat regular oval outline. Its longer axis lies in a general northeast-southwest direction. Viewed from the top of the highest point the surface appears as if the whole mound has been made up of a series of sinaller mounds grouped around a central one, and the whole so intimately connected as to give the appearance of

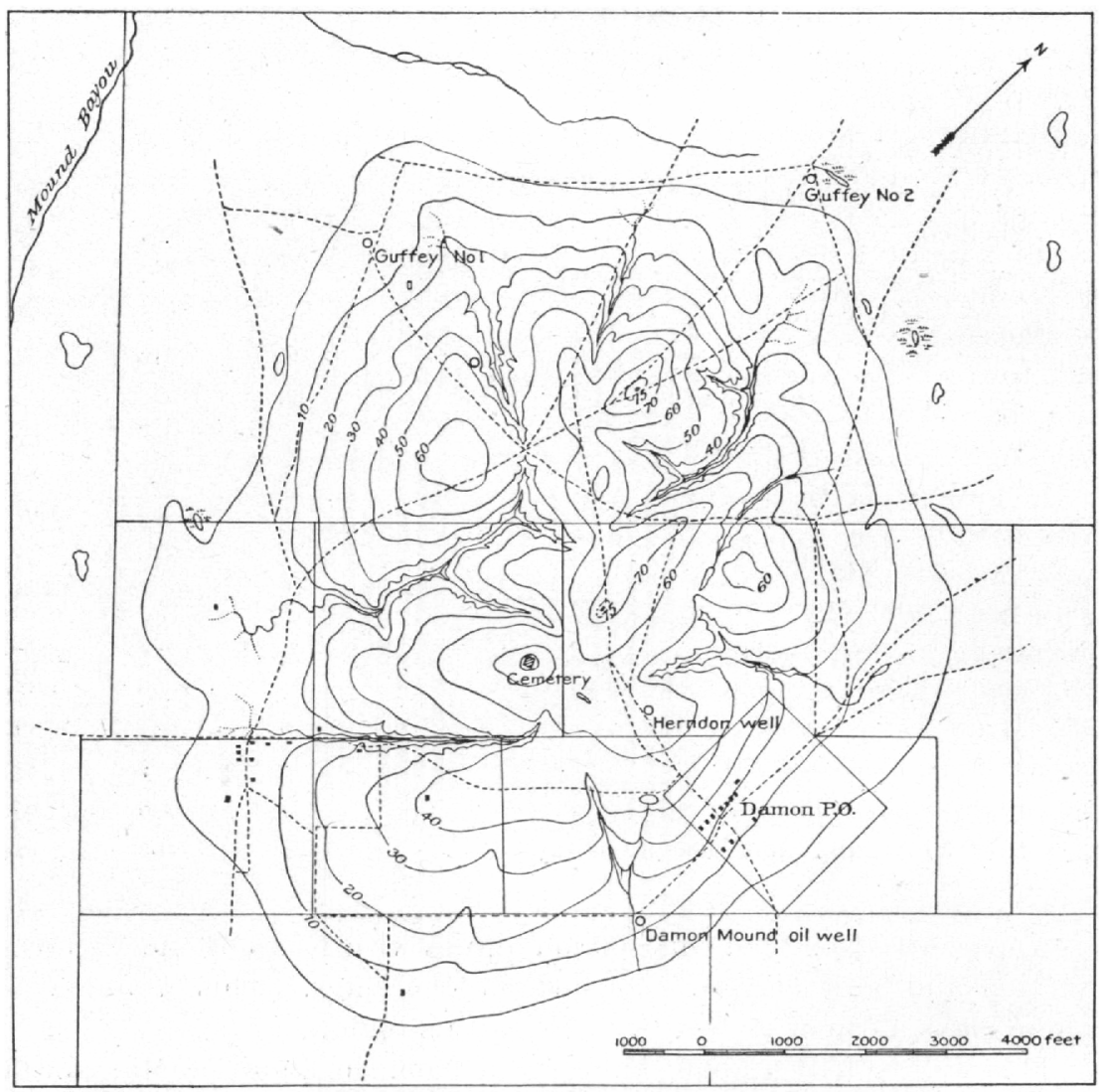

Fig. 1.-Sketch contour map of Damon Mound; by A. C. Veatch.

one extended hill. The form of its surface is in part due to erosion, but the peculiar geologic structure of the mound suggests that these irregularities may be in part constructional. The presence of extensive deposits of salt shown in the Herndon well and its absence in other wells in the immediate vicinity, together with the occurrence of sulphur and the structure of the mound so far as it can be made out, suggest a close similarity with the Salt Islands of Louisiana.

The greater portion of this mound is covered with blue and red clays. On the western slope brown sandy elays and shaly clays 
appear on the surface. Several small veins or seams of sulphur, evidently deposited by escaping gases, fill cavities in the sandy clays, and considerable quantities of the same mineral oceur in the form of erystals disseminated through the beds. This brown sandy material with its inclosed sulphur, locally known as "sour dirt," was at one time mined by the Damonia Mineral Company and shipped to Chicago for medicinal purposes.

In a well 40 feet deep a short distance southeast of the hotel at Damon post-office the water is saline, while wells along the southwestern edge of the mound near the old town of Damon afford fresh water.

Drilling operations in this field have been carried on by the J. M. Guffey Petroleum Company and the Damon Mound Oil and Pipe Line Company. The J. M. Guffey Company has drilled three wells-Nos. 1 and 2 and the Herndon well. Well No. 1 is located near the base of the mound on its northwestern side, while No. 2 is located near its northeastern end. The IIerndon well has been drilled near its summit toward the south side. The Damon Mound Company's well is near its southeastern base. The New York and Texas Oil Company, although making preparations, has not commenced operations.

No petroleum in any quantity has as yet been found in Damon Mound. In the Herndon well the drill entered rock salt at 587 feet, and was still cutting through it at a depth of 1,160 feet, thus giving a known thickness of salt in this well of 573 feet.

The logs of the wells drilled in the I)amon Mound field are as follows:

Log of Herndon well, Damon Mound.

[Elevation, 140 feet.]

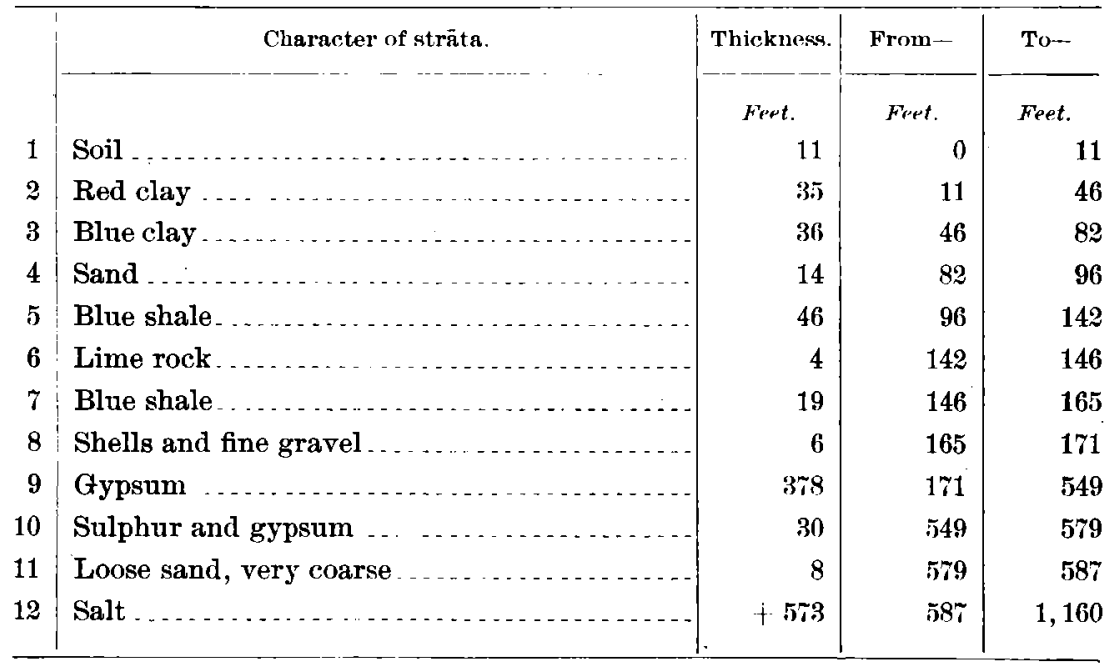


No traces of oil were reported from this well, but considerable quantities of sulphur water were found. The upper beds of limestone and a portion of the gypsum-bearing beds were found to be badly fissured or fractured, occasioning a considerable loss of time and additional expense in drilling.

Log of Well No. 1 of the J. M. Guffey Petroleum Company.

[Elevation, 60 feet.]

\begin{tabular}{|c|c|c|c|c|}
\hline & Character of strata. & Thickness. & From- & To- \\
\hline 1 & Gray sand $\ldots$ & $\begin{array}{l}\text { Feet. } \\
\\
3\end{array}$ & $\begin{array}{l}\text { Feet. } \\
0\end{array}$ & $\begin{array}{l}\text { Feet. } \\
\end{array}$ \\
\hline 2 & Black clay . . . . . & 15 & 3 & 18 \\
\hline 3 & Brown sand. & 22 & 18 & 40 \\
\hline 4 & Blue clay ..... & 5 & 40 & 45 \\
\hline 5 & White sand & 20 & 45 & 65 \\
\hline 6 & Clay - & 20 & 65 & 85 \\
\hline 7 & Fine gravel & 6 & 85 & 91 \\
\hline 8 & Sand . . . . . . & 39 & 91 & 130 \\
\hline 9 & Clay - - - & 9 & 130 & 139 \\
\hline 10 & Sand $\ldots \ldots$ & 19 & 139 & 158 \\
\hline 11 & Blue shale . . . . & 32 & 158 & 190 \\
\hline 12 & Sand. & 9 & 190 & 199 \\
\hline 13 & Clay & 22 & 199 & 221 \\
\hline 14 & Blue shale ....... & 16 & 221 & 237 \\
\hline 15 & Sand and shells & 18 & 237 & 255 \\
\hline 16 & Wood (cypress) & 2 & 255 & 257 \\
\hline 17 & Coarse water sand. & 40 & $25 \%$ & 297 \\
\hline 18 & Blue shale & 36 & 297 & 333 \\
\hline 19 & Lime and sandstone mixed & 5 & 333 & 338 \\
\hline 20 &  & $\mathfrak{2} 2$ & 338 & 360 \\
\hline 21 & Sand and wood (wood 1 foot) & 14 & 360 & 374 \\
\hline 22 & Hard rock & 2 & $3 r 4$ & 376 \\
\hline 23 & Blue shale & 32 & 376 & 408 \\
\hline 24 & Sand and shells . - & 17 & 408 & 425 \\
\hline 25 & Clay & 12 & 425 & $43 \%$ \\
\hline 26 & Sand rock & 4 & $43 i$ & 441 \\
\hline 27 & Blue shale ........ & 37 & 441 & 478 \\
\hline 28 & Sand and shells & 23 & 478 & 501 \\
\hline 29 & Sand rock $\ldots \ldots$ & 7 & 501 & 508 \\
\hline 30 & Clay $\ldots \ldots \ldots$ & 18 & 508 & 526 \\
\hline 31 & Sand and cedar log & 14 & 526 & 540 \\
\hline 32 & Sand rock and gas.... & 11 & 540 & 551 \\
\hline 33 & Sand . . . . . . & 9 & 551 & 560 \\
\hline 34 & Clay . . . & 16 & 560 & 576 \\
\hline
\end{tabular}


Log of Well No. 1 of the .J. M. Guffey Petroleum Company-Continued.

\section{Character of strata.}

Sand rock and gas

Sand

Sand rock

Sand

Sand and lime rock

Gravel and water

Fine sand

Sand rock

Sand

Loose dirt and sulphur, apparently the same bed as No. 10 in the Herndon well

Blue shale

Sand rock

Very fine sand

Sand rock.

Sand, medium.

Clay

Fine sand

Sand rock

Blue shale

Lime rock

Blue shale

Sand rock

Blue shale

Lime and sand rock, very hard and flinty

\begin{tabular}{|r|r|r} 
Thickness. & From- & \multicolumn{1}{c}{ To- } \\
\cline { 1 - 3 } Feet. & Feet. & \multicolumn{1}{c}{ Feet. } \\
3 & 576 & 579 \\
10 & 579 & 589 \\
14 & 589 & 603 \\
41 & 603 & 644 \\
19 & 644 & 663 \\
2 & 663 & 665 \\
30 & 665 & 695 \\
2 & 695 & 697 \\
32 & 697 & 729 \\
& & \\
17 & 729 & 746 \\
39 & 746 & 785 \\
8 & 785 & 793 \\
44 & 793 & 837 \\
3 & 837 & 840 \\
49 & 840 & 889 \\
6 & 889 & 895 \\
45 & 895 & 940 \\
18 & 940 & 958 \\
31 & 958 & 989 \\
3 & 989 & 992 \\
58 & 992 & 1,050 \\
6 & 1,050 & 1,056 \\
35 & 1,056 & 1,091 \\
$6+$ & 1,091 & 1,097 \\
& & \\
\hline & &
\end{tabular}

Log of the Damon Mound Oil and Pipe Line Company's well.

[Elevation, 100 feet.]

\begin{tabular}{|c|c|c|c|c|}
\hline & Character of strata. & Thickness. & From- & To- \\
\hline 1 & Clay ............. & $\begin{array}{l}\text { Feet. } \\
\quad 260\end{array}$ & $\begin{array}{l}\text { Feet. } \\
\\
\end{array}$ & $\begin{array}{l}\text { Feet. } \\
\quad 260\end{array}$ \\
\hline 2 & Limestone & 70 & 260 & 330 \\
\hline 3 & Clay ...... & 200 & 330 & 530 \\
\hline 4 & Limestone & 650 & 530 & $1, \mathbf{1 8 0}$ \\
\hline 5 & Sand and clay ..... & 50 & 1,180 & 1,230 \\
\hline
\end{tabular}

This well is located a little over three-quarters of a mile south of the Herndon well. The gypsum of the Herndon well is here represented by limestone, while the 650 feet of limestone No. 4 of the 
Damon Mound well apparently is equivalent to the salt deposits of the Herndon well, and also the 30 feet of sulphur and gypsum.

Log of Equitable Mining Company well at Kise. Heights, about ₹ miles vest of Columbia.

[Elevation, 34 feet.]

\begin{tabular}{|c|c|c|c|c|}
\hline & Character of strata. & Thickness. & From- & To- \\
\hline & & Feet. & Feet. & Feet. \\
\hline 1 & White clay & 2 & 0 & 2 \\
\hline 2 & Red clay. & 8 & 2 & 10 \\
\hline 3 & Gray sand & 15 & 10 & 25 \\
\hline 4 & White clay & $\frac{1}{2}$ & 25 & $25 \frac{1}{2}$ \\
\hline 5 & Quicksand .. & $24 \frac{1}{2}$ & 25 견 & 50 \\
\hline 6 & Yellow clay ... & 10 & 50 & 60 \\
\hline 7 & Quicksand & 1 & 60 & 61 \\
\hline 8 & Gray sand. & 23 & 61 & 84 \\
\hline 9 & Lignite with logs & 6 & 84 & 90 \\
\hline 10 & White clay . . . . & 15 & 90 & 105 \\
\hline 11 & Soapstone (clay) & 15 & 105 & 120 \\
\hline 12 & Blue shale & 14 & 120 & 134 \\
\hline 13 & Blue clay & 18 & 134 & 152 \\
\hline 14 & Rock and gas . .... & 4 & 152 & 156 \\
\hline 15 & $\begin{array}{l}\text { Blue sand and clay with thin streaks of rock, } \\
\text { water in rock }\end{array}$ & 112 & 156 & 268 \\
\hline 16 & Rock & 1 & 268 & 269 \\
\hline 17 & Sand ..... & 1 & 269 & 270 \\
\hline 18 & Blue clay . . . & 18 & 270 & 288 \\
\hline 19 & Hard rock $\ldots$ & 7 & 288 & 295 \\
\hline 20 & Blue clay ....... & 19 & 295 & 314 \\
\hline 21 & Quicksand and gas ..... & 6 & 314 & 320 \\
\hline 22 & Blue shale with some oil . . & 38 & 320 & 358 \\
\hline 23 & Rock with black particles. & 1 & 358 & 359 \\
\hline 24 & Oil sand & 1 & 359 & 360 \\
\hline 25 & Blue sand - & 20 & 360 & 380 \\
\hline 26 & Sand & 44 & 380 & 424 \\
\hline 27 & $\ldots$.... do $\ldots . .$. & 76 & 424 & 500 \\
\hline 28 & Rock with some oil & K & 500 & \\
\hline
\end{tabular}

This well has been drilled to about 600 feet, where the gas pressure was strong enough to blow the well out. This gas was accompanied with a large flow of water with a small quantity of oil.

Along the San Bernard River, about 8 miles northwest of Damon Mound, there outcrops a soft grayish-white limestone which strongly resembles the Reynosa limestones of the West, and which may be traced to the upper exposed bed of limestone in Damon Mound. 
Limestones also appear in the wells at Velasco at 735 feet and at Columbia at 156 feet. Whether or not these may be correlated with the Reynosa, sufficient knowledge is not yet available for determining. With the exception of the limestone reported in the Big Hill well in Matagorda County, no limestones are known to exist in this region, and the nearest Reynosa limestones occur at Rogers in Nueces County, at least 135 miles distant.

It will be noticed that the first bed of limestone found in these wells lies in such a position as to appear in all. It is interbedded between two thick beds of clay, except in the Velasco well, where its underlying bed is not known, and a thin bed of gravel intervenes between the clay and limestone. This limestone appears to be irregular in thickness. In the Guffey No. 1 and Herndon wells it does not show a thickness exceeding 4 to 5 feet. In the Colnmbia well the thickness recorded is 5 feet, but in the Damon Mound Oil and Pipe Line Company's well, about a mile south of the Herndon well, the reported thickness is 70 fret. Its thickness in the Velasco well is not known.

From the depths given, this limestone appears to dip in a southeasterly direction from the summit of Damon Mound at the rate of 25 feet per mile. On the northern side of the mound the dip is to the northwest at the rate of 93 to 95 feet per mile. About 8 to 10 miles northwest of the summit the same limestone comes to the surface in the bed of the San Bernard River. The beds shown in that locality are dipping toward the mound at a rate of approximately 33 feet per mile. Another noticeable feature of the region is the appearance of a minor fold in the Columbia field. The area or extent of this minor fold is not known.

From these figures it would seem as if the regular dip of these beds, including the limestones as well as sandstones lying at greater depths, is southeast toward the coast. The dip is probably interrupted by a fold, and probably a fault at Damon Mound, beyond which the beds resume their normal southeasterly dip.

How far to the east or west these folds may extend is not known. No drilling has been done to the west except at Big Hill, in Matagorda County, approximately 20 miles to the southwest. In the Big Hill well limestones occur at various depths, and it is possible that these are the same beds as those forming the minor fold in the Columbia field and that the minor fold has a length of at least 20 miles. From this it might be inferred that some traces of the main fold may be found lying in the same direction.

Toward the east it is doubtful whether drilling would show any continuation of the Columbia well limestones. No drilling has been done in the line of the arch projected, but at Angleton, a few miles to the south of such a line, the Brazos Valley Oil Company and New York and Texas Land Company have drilled wells, the former to the depth of 1,500 feet and the latter through sand and clay to a depth of 600 feet. 
The limestone found in the Velasco well at about $7+5$ feet, where the gas flow was struck, is apparently closely allied with the limestone found in the Matagorda County well at about 900 feet, in which a similar flow of gas occurred. In both cases it caused the abandonment of the wells. A similar heavy flow of gas occurred in the Equitable Mining Company's well at Columbia at a depth of about, 600 feet. Little or no gas occurs in the wells at Damon Mound.

DETAILED SECTIONS BETWEEN BRAZOS ANI TRINITY RIVERS.

In the region lying between the Brazos and Trinity rivers a new topographic feature is introduced. From the western boundary of the region discussed eastward as far as (ialveston Bay the coast line is protected by a series of long, narrow islands, or keys, separated from the mainland by narrow, shallow lagoons. 'These lagoons show more or less of a bluff structure along their inner or landward shores. This shore bluff, beginning at an elevation of a few feet at Point Isabel, crarlually increases in elevation until it reaches its highest point in the neighborhood of Corpus Christi. From that point the bluff lessens in height until it reaches the shore of Galveston Bay. On the east side of the bay, in the neighborhood of East lBayou and up along the eastern shore to the month of Trinity River and Cedar Bayou, commences the low, flat sea marsh area which continues eastward and forms an extended territory in the southern portion of Jefferson and Orange counties in Texas and Cameron and Vermilion parishes in Louisiana.

In the same limits there are also numerous mound-shaped elevations which may be in part remnantal and due to erosion and in part due to the uplifting of the underlying beds. The Sun Mounds in Waller County are representative of the first class, and Dayton Hill, Barber Hill, and Davis Hill probably belong to the second class.

In its general features this portion of the country has the same characteristics as the counties lying immediately to the west of the Brazos. The general section shows the Fayette sands to comprise a series of gray and yellow sandstones, more or less calcareous in some portions, and interstratified with coarse, yellow sand and beds of siliceous yellow limestones. The beds are somewhat lenticular in form and the material is very irregular in texture, often passing from a solid, close-grained sandstone to a loose, unconsolidated sand in a distance of a few hundred yards.

The southern boundary of this series and its contact with the succeeding Frio clays is often obscured by heavy beds of gravel which form a belt over 3 miles in width and 15 to 20 feet in thickness. This boundary passes across the counties of Grimes, Montgomery, and Walker in a general northeastern direction from near Chappel Hill, in Washington County, passing Courtney and Anderson, in Grimes County, and crossing the Trinity near Riverside on the Inter- 
national and Great Northern Railroad. In this portion of the state these sandstones ocoupy a somewhat restricted ared and have an estimater thickness of 350 feet.

The Frio clays overlying these Fayette sands have in this area a thickness of 75 to 100 feet and rest more or less unconformably upon the eroded surface of the Fayette beds. The Frio clays here comprise a series of blue, yellow, and sometimes red clays, with concretions or nodules of lime carbonate interstratified with occasional beds of gray calcareous sands and thin-bedded, coarse-grained, soft, calcareous sandstones. The clays are mostly massive (although occasionally shaly or thin-bedded deposits occur) and show a tendency to break up into cuboidal blocks. The colors also tend to intergrade, although at most localities there is a strongly defined line of color demarcation, but no sign of any change in the character or texture of the clays. In other words, changes of color do not inclicate any change of bedding. The lime nodules vary from 2 to 4 inches in diameter and show different degrees of hardness. When exposed to the air they slake or crumble to a fine powder. 'The greological survey of Texas" gives two sections showing the character of these Frio beds. One is as follows:

Section of Frio beds between Brazos and Trinity rivers.

Feet.

1. Brown sand.

2. Grayish sandy clay with concretions or nodnles of lime $\ldots \ldots \ldots \ldots \ldots$

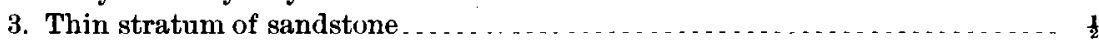

4. Bluish-gray sand with nodules of lime and clay _. $\ldots \ldots \ldots \ldots \ldots$

In the second section, near Courtney, the beds are shown to be blue clays, changing to red, and in places white, containing numerous nodules or concretions of lime.

This series occupies a comparatively narrow strip, probably not more than 15 or 20 miles in width. The base of the series is seen in the Christian well, near Courtney, Grimes County, and is found in wells at Howth station, in Waller County, and exposed in Iime Creek, 4 miles south of Hempstead. These clays can be traced in a general northeastern direction to Longstreet, Montgomery County. From Longstreet to Dodge, on the International and Great Northern Railroad, they rarely come to the surface, being for the greater distance completely overlapped by the mottled sands and clays of the succeeding deposits. At Point Blank post-office, in the northern end of San Jacinto County, these calcareous clays are seen in the following section:

Section at Point Blank post-office, San Jacinto County, Tex.

Feet.



2. Calcareous clays with lime in nodules or concretions $\ldots \ldots \ldots \ldots \ldots \ldots \ldots+5$

Succeeding the Frio clays, and in many places completely obscuring them, is a series of red and brown clays and sands, with occasional indu- 
rations or soft sandstone. The sands are often cross bedded and contain nodules or concretions of pinkish clay varying in size from a few inches to a foot in diameter; the clays are blue and red, laminated or thinly stratified, and blue and red mottled. These beds toward the western end of the district, or in the Brazos River section, appear chiefly in their brown cross-bedded sandy condition, and small exposures of them may be seen in the river banks north and west of Hempstead and also in the shallow cuttings on the Houston and Texas Central Railroad between Hempstead and Hockly, in Waller County, where they appear to merge into the general level of the Coastal Plain proper. So small a difference in elevation occurs that these brown sands may be said to be the lowest member of the coastal deposits in this region. At Conroe, in Montgomery County, these beds still maintain their brown sandy character, although they have risen more than 80 feet above their level at Ilempstead. Northward from Conroe these beds occur as laminated blue and red clays, and east,ward along the Trinity they appear as bright-red, pink, and brown heavy-bedded clays, rising to considerable elevations above the river valley. At Dodge, in Walker County, they are between 20 and 30 feet in depth and overlie the blue joint clay of the Frio beds, and at Point Blank, 14 miles farther east, brown sands of this series are seen overlying the blue calcareous Frio clays. 'The red sands forming the capping of the Sun Mounds in Waller Connty may possibly belong to these beds, although the present conditions would presuppose a large: amount of erosion or a considerable uplift after these sands were laid down. Occasional deposits of gravel appear in connection with these sands.

These brown sands and clays appear to mark the beginning of a new epoch. They are unconformable with the underlying Frio clays, and in many places have so overlapped them as to obscure them altogether. At other places much erosion has taken place before the deposition of the brown sands and clays. In many places the sands are cross bedded and show an otherwise irregular deposition. The total thickness of the sands and clays of this division has been estimated at 350 feet.

These beds are referred to the Isafayette and are correlated with the Oakville beds in the western end of the plain and the Loup Fork beds by Dumble and regarded as of late Miocene or early Pliocene age.

Southward from these brown sands and clays is a series of graywhite, bluish-gray mottled, and yellow sands with occasional thin lens-like deposits of blue, gray, and yellow clays containing irregular gravel deposits and many concretions and beds of indurated sands forming a soft sandstone. These practically occupy the whole country from the upper margin of the underlying brown glays to the latitude of Houston. Owing to the generally level surface of the country occupied by these beds, reliable sections are rarely seen. These 
sands appear in several small cuttings along the line of the Missouri, Kansas and Texas Railway going westward from Houston; and near Brunner, on Buffalo Bayou, in the vicinity of Houston, banks from 15 to 20 or more feet high are made up of the brownish-gray sand with thin ledges of coarse soft sandstone or sand concretions of this formation. The same sands are also found in cuttings near the San Jacinto River, and at Crosby, on the Southern Pacific Railroad east from Houston. The sandy deposits also form the summit of Dayton Hill, in Liberty County, and show a thickness of at least 15 feet in cuttings along the line of railroad. South of Dayton they form the bluff marking the edge of the 'Trinity River bottom lands. Indurations of these sands in the form of sandstones occur at many places. Near Tarkington Prairie, in Liberty County, and between that place and the Trinity River, they form hills of considerable height and extent. These indurations also occur on the same river about 3 miles northwest of the town of Liberty, as well as at several places south and east, notably in old ballast pits a little east of the town.

Of economic in terest in connection with these sands are the various small deposits of carbonate of iron found in the form of thin, irregular sheets or as stains throughout the beds. This ore is freely soluble in carbonated water, and seepage carries the solution out into small gulches or ravines, where, coming in contact with oxygen, the iron is precipitated and forms a brilliant iridescence on the surface of the water. This has frequently been mistaken for petroleum, and many of the so-called petroleum springs or seeps found in the areas belonging to these beds are this iron in course of deposition.

From Houston south to the coast the country is almost flat, perhaps sloping at a rate of 10 inches to 1 foot per mile. This region is occupied by the clays and sands of the Beaumont beds and clays and sands of post-Pleistocene age, while in the immediate vicinity of the head of Galveston Bay the coastal or sea marshes begin.

The underground conditions of this section are practically unknown. Few wells of great depth have been drilled, the most important being the deep well at Galveston (3,070 feet) and the deep well at Huntsville (about 2,203 feet). The section of the Huntsville well is as follows:

Section of well at Huntsville.

1. Clays and sandy clay, with water bed at 339 feet

Feet.

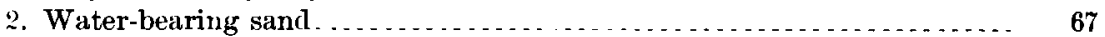

3. Clays, etc . . . . . . . . . . . . . . 506

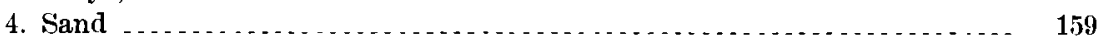

5. Clays . . . . . . . $47 \ldots$

6. Sands . . . . . . .

2,203

Several wells, ranging from 600 to 900 feet in depth, have been drilled at IIouston. The Brazos Valley Oil Company and the New York and 'Texas Land Company's wells at Angleton have already been referred 
to. On the Smith league, on Cedar Bayou, a well 238 feet, giving the following section, was drilled several years ago:

Log of well on Smith league, on Cedar Bayou, Texas.

Feet.

1. Red clay .



3. Bluish clay, with shells . . . . . . . . . . . . . . . . . . . . . . . . . . . 40

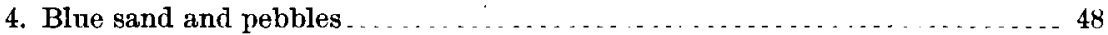

At Dayton the J. M. Guffey Petroleum Company drilled a well 1,900) feet deep, and on the north side of the hill the Taylor-Dayton Company has been drilling to depths of from 500 to 1,000 feet. At Stillson the Hill-Brown Rice Land and Irrigation Company has drilled two wells nearly 500 feet in depth.

The $\log$ of the Taylor-Dayton Company's well shows that Dayton Hill is composed of blue clays and sands to a depth of 500 feet, with bowlders of a soft gray sandstone at several horizons. These bowlders are rounded and concretionary, readily breaking into thin slaty portions, and appear to lie in a blue marly clay and to overlie heavy beds of quicksand. At 600 feet this well passed into limestones to the depth of 800 feet and then rock salt to 1,200 feet. In the Guffey well, 6 miles farther south, thin beds of sandstone are reported at various depths, but chiefly below 800 feet. Gravels also occur in this well record in the lower depths. In the Stillson well, 3 miles west of Dayton, yellow clays were drilled through to a depth of 104 feet. These were followed by 19 feet of quicksand, and from that depth to 447 feet the section shows mostly a series of blue clays. Lime concretions were found from 132 to 174 feet and again between 244 and 263 feet. No bowlders were found in this well, which terminated in 40 feet of coarse gravelly sand with water. The following are the logs of these wells as supplied by the companies:

Log of Taylor-Dayton Conupany well, sec. 1134 Houston and Texas Central Railroad Company's lands, Liberty County.

[Elevation, 100 foet.]

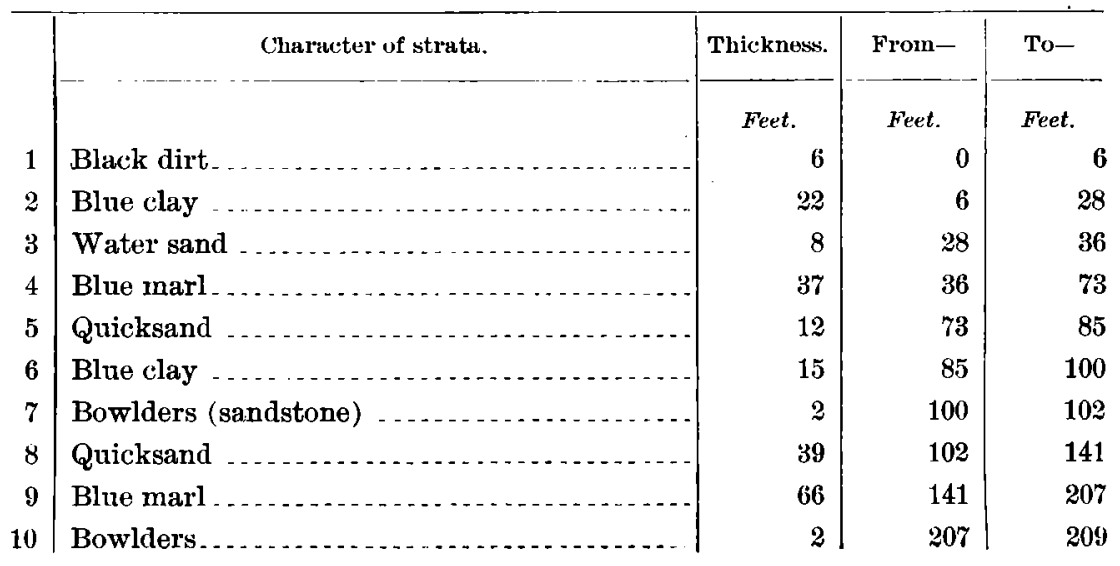


Log of Taylor-Dayton Company well, ete.-Continued.

\begin{tabular}{|c|c|c|c|c|}
\hline & Character of strata. & Thickness. & From- & To- \\
\hline & & & $\begin{array}{l}\text { Feet. } \\
\quad 209\end{array}$ & $\begin{array}{l}\text { Feet. } \\
\quad 229\end{array}$ \\
\hline 12 & Blue marl and bowlders & 3 & 229 & 232 \\
\hline 13 & Blue marl . . . . . . . . . & 6 & 232 & 238 \\
\hline 14 & Bowlders,$\ldots \ldots \ldots$ & 3 & 238 & 241 \\
\hline 15 & Blue marl (gas at 244) & 32 & 241 & 273 \\
\hline 16 & Quicksand & 47 & 273 & 320 \\
\hline 17 & Water sand .. & 6 & 320 & 326 \\
\hline 18 & Quicksand .. & 3 & 326 & 329 \\
\hline 19 & Blue marl & & & \\
\hline
\end{tabular}

This well is now nearly 1,200 feet deep and is being drilled in rock salt.

The $\log$ of the Hill-Brown Rice Lind Company's well, at Stillson, shows the following:

Log of Hill-Brown Rice Land well, on sec. 138 of the Gulf, Colorado and Santu Fe Railroad lands, Liberty County, Tex.

[Elevation, 85 feet.]

\begin{tabular}{|c|c|c|c|c|}
\hline & Character of strata. & Thickness. & From- & To- \\
\hline 1 & Yellow clay - & $\begin{array}{l}\text { Fet. } \\
104\end{array}$ & $\begin{array}{l}\text { Feet. } \\
\\
0\end{array}$ & $\begin{array}{l}\text { Feet. } \\
\quad 104\end{array}$ \\
\hline 2 & Quicksand ... & 19 & 104 & 123 \\
\hline 3 & Hard clay . - . & 6 & 123 & 129 \\
\hline 4 & Sand $\ldots \ldots$ & 3 & 129 & 132 \\
\hline 5 & Hard clay and lime pebbles. & 42 & 132 & 174 \\
\hline 6 & Soft clay ....... & 10 & 174 & 184 \\
\hline 7 & Sand . & 10 & 184 & 194 \\
\hline 8 & Hard blue clay . . . . . & 44 & 194 & 238 \\
\hline 9 & Soft blue clay & 6 & 238 & 244 \\
\hline 10 & Soft blue clay with lime. & 19 & 244 & 263 \\
\hline 11 & Hard blue clay & 13 & 263 & 276 \\
\hline 12 & Soft blue clay $\ldots \ldots$ & 16 & 276 & 292 \\
\hline 13 & Hard blue clay :.... & ij & 292 & 297 \\
\hline 14 & Soft blue clay & 17 & 297 & 314 \\
\hline 15 & Hard blue clay ......... & 20 & 314 & 334 \\
\hline 16 & Fine gray sand ... & 15 & 334 & 349 \\
\hline 17 & Hard blue clay ...... & 9 & 349 & 358 \\
\hline 18 & Yellow clay and sand & 49 & 358 & 407 \\
\hline 19 & Very hard yellow clay ... & 5 & 407 & 412 \\
\hline 20 & Yellow sand and clay..... & 35 & 412 & 447 \\
\hline 21 & Coarse gravelly sand to bottom. & 40 & 447 & 487 \\
\hline
\end{tabular}


'The $\log$ of the J. M. Guffey Petroleum Company's well is not avail-' able.

The section shown in the Galveston well has already been published in several places, ${ }^{a}$ so need not be repeated here except to show the ages assigned to the various deposits. According to Harris ${ }^{b}$ the deposits found appear to be as follows:

Section of Gulveston well.

Feet.

46 to 458

Pleistocene

458 to 1,510

Doubtful

$1, \overline{5} 10$ to 2,158

Upper Tertiary .

2,158 to 2,920

These have been partially correlated with the deposits found in the well at the State penitentiary at Iuntsville.

\section{DETAILED SECTIONS IN VICINITY OF NECHES AND SABINE RIVERS.}

Fastward from the 'Trinity the general features of the country are very similar to those of the section last described, west of that river. The topography is that of a level plain, mostly prairie, but timbered along its northern margin and swampy along the Gulf coast.

It is in this eastern division that the so-called hills, or more properly prairie swells, which play so important a rôle in oil prospecting, are most extensively developed. Near the coast are High Island and Big Hill, in Jefferson County, while farther inland are the present oilproducing regions of Spindletop, Sour Lake, and Saratoga. In addition to these there are several smaller and apparently less developed elevations, of which the more important is Fairchild Hill, situated about 4 miles west of Sour Lake station. It rises with considerable abruptuess to an elevation of 95 to 30 feet above the general level of the country and covers approximately 50 acres. Small ponds or depresssions holding water are scattered over the top, and more or less gas appears in the neighborhood of these depressions. About 2 miles southwest of Fairchild Hill lies another hill of about the same extent and elevation. 'This is of a somewhat irregularly oval form and is nearly covered by a single pond. The crest of the hill forms a natural embankment, and confines the water, which covers 2 or 3 acres. Gas also occurs in the neighborhood of this pond.

In Orange County occur several similar though smaller elevations, but these, as well as some others in other portions of the Coastal Plain, are not named.

In the Louisiana region the most important elevations are Hackberry Island, in Cameron Parish, Vinton and Sulphur mine, in Calcasieu Parish. Besides these are a number of other smaller and less noticeable elevations. 
While some of these hills, and perhaps most of them, are due to the geologic structure, others are probably due in part at least to erosion.

A peculiar topographic feature of the Gulf Coastal Plain in Texas and Louisiana, but especially well developed in this eastem division, is the "pimpled plain." Iarge areas are covered with small mounds, generally circular in outline, from 20 to 60 feet in diameter and from 2 to 10 feet in height. In some cases they are so close together as to be in contact, but they are generally separated by distances varying from a few rods to a quarter of a mile. Large areas of the plain are entirely free from the mounds, though not otherwise different in character of soil or underlying formations from the pimpled plains. The mounds are composed of fine sand or sandy loam even where the surrounding plain has a clay soil. Numerous theories have been proposed to explain the origin of these mounds, but none of them are entirely satisfactory, and they need not be enumerated here.

The presence of these mounds was considered, during the early prospecting of the Texas field, a favorable indication of the presence of oil, and much drilling was done on the strength of this indication. No rational theory for their origin, however, connects them in any way with deep-seated commercial deposits of oil or gas, and experience has shown that they have no connection with such deposits. Their presence or absence should, therefore, be wholly ignored by the oil prospector.

The northern boundary of the Fayette sands crosses the Trinity a short distance south of Hyde's ferry in Houston County, passing in a general northeast direction past Pennington, where it turns easterly and reaches the south side of the Neches River near Clark's ferry, where the Houston Fast and West Texas Railroad crosses that stream. Crossing the river near Rockland, in Tyler County, the line turns northeastward past Brookland, about \& miles north of .Jasper, and crosses the Sabine River near the mouth of Little Sandy Creek, in Sabine County.

From the crossing of the Trinity near Riverside the southern border follows a somewhat irregular line in a generally eastern direction, passing between Corrigan and Moseow, near Bowers, on the Missouri, Kansas and Texas Railroad; Summit, on the Texas and New Orleans Railroad; Jasper; Farrs, a few miles north of Burkesville; and crosses the Sabine about 3 miles north of Burr's ferry.

The composition of the Fayette beds has generally been described as gray sands, sandstones, and gray clays. In this area the Fayette is made up of gray and white sandstones; gray and pinkish-gray sands; gray, pinkish-white, and white, with occasional beds of palegreen clay; one or more beds of white fossiliferous limestone, and brown or yellowish-brown sandy clays containing many impressions of leaves and stems of plants, among which leaves resembling the gum appear to be the prevailing form, Along the line of the Hous-

Bull. 212-03-t 
ton East and West Texas Railroad, between Clark's ferry crossing and Moscow, the following section occurs:

Section on Houston East and West Texas Railroad between Clark's ferry und Frio: Moscow.

1. Coarse gray sand

2. Laminated blue and white sand . . . . . . . . . . . . . . . . . . . . . . . . . 15 Fayette:

3. Brownish-gray to yellow sandstone, gradually losing, its brown tint as it nears the base. The upper, brown division is thinly laminated and contains plant impressions and nodules of pureclay. The lower, gray division contains clay nodules but no plants; 4 feet in railway cut, but 15 feet in Hitchcock's quarry . .

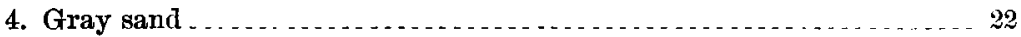

5. White limestone containing casts of Venericardia planicosta and other

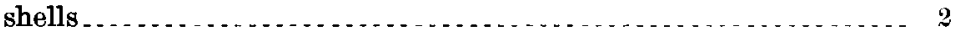

6. Indurated gray sand or soft sandstones

7. Gray cross-bedded sands _ $\ldots$

8. Gray sands with opalized wood . . . .

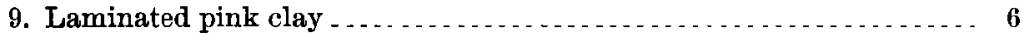

10. Gray laminated and grayish-brown sand _................ $2 \frac{1}{2}$

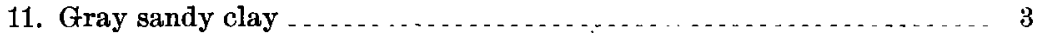

12. Gray sandstone $\ldots \ldots \ldots \ldots$

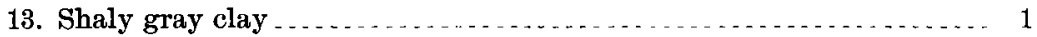

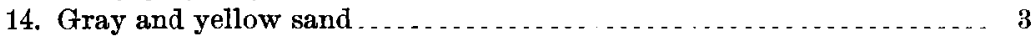

15. Light-yellow or cream-colored clay ..................... 2

16. Thinly laminated gray sandstone $\ldots \ldots \ldots \ldots$

17. Brown laminated clay _...

18. Thinly stratified white or gray sandstones .................. 1

19. Gray sandstones stained brown .............................. 3 Yegua:

20. Thinly stratified or laminated blue clay with gypsum in crystals _.. 35

At Rockland these beds give the following section:

\section{Section at Rockland.a}

1. Gray sand and siliceous pebbles . . . . .

2. Mottled blue and brown sandy clay ..................... 20 Frio:

3. Green sandy clay $\ldots \ldots$

4. Brown sandy clay . . . . . . . . .

5. Pale-blue sand and clay ...................... 15

6. Dark-blue clay with lime concretions $\ldots \ldots$

7. Drab-gray sandy clay . . . . . . . . . . . . Fayette:

8. Gray sandstones, coarse grained on top but changing to a fine-grained, blue, hard quartzitic stone at base . . . . . . . . . . . . . . . . . . . 120

In this section the Frio clays overlie the Fayette beds and are in turn overlain by the blue and brown sands and sandy clays seen at Colmesneil. 
Still farther east, at Rock Branch, 5 miles south of Brookland, in Jasper County, the coarse gray sandstones are shown in a bluff on the bank of the creek, but their thickness is unknown. In this region the rock is badly broken up and covers the face of the hill for over 200 feet, the sandstones being broken into large blocks, in many places over 3 feet in thickness. Along the line of the Gulf, Beaumont and Kansas City Railway in this vicinity the upper bed of sandstone appears to vary from 2 to $t$ feet in thickness and to be underlain by heavy beds of yellow and pink clays. Several of the cuttings show that the sandstones have been eroded, leaving the clays to form the surface throughout the valleys. The region comprises a hilly country, showing deep valleys and knob-like hills. These hills are generally covered with a brownish-gray conglomerate containing great quantities of white quartz pebbles.

In Newton County the sandstones are not much exposed. The rounded knob-like hills found in Jasper County extend across Newton County and into the lower portion of Sabine County. A section on Little Sandy Creek shows the lignites of the underlying Yegua beds beneath the sandstones. The section is as follows:

\section{Section on Little Sandy Creek.}

Fayette:



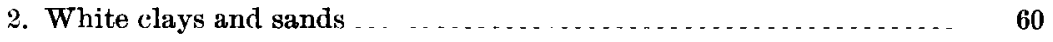
Yegua:

3. Lignite

On the Sabine River the sections seen at Snells Landing, IIarden Ferry, and Runyons Bluff show the Fayette beds in this region to be gray sandstones with thinly laminated pink and white clays, the sandstone beds ranging from 1 to 6 feet in thickness.

Passing into Iouisiana, the same sandstones, with their associated clays, appear in the SW. $\frac{1}{4}$ sec. 2, T. 5 N., R. 13 W. Between IIornbeck and Christie the section shows the sandstones underlying the blue calcareous clays of the Frio beds. The sandstones also occur at Kisatchee, Lena, Fairmount, and as far east as IIarrisonburg, in Louisiana.

Along the southern border of these beds the exposures are by no means satisfactory. They usually pass under the Frio clays' in such a way as would lead to the inference that the sandstones underwent considerable erosion during the period in which the Frio beds were deposited. The Fayette beds dip S. $30^{\circ} \mathrm{E}$.

Succeeding the Fayette beds the Frio clays occupy a belt of country of somewhat irregular width but probably never exceeding 15 miles. The Frio beds are dark to pale blue, brown, red, yellow, and green clays, with a few thin strata of a ferruginous sandy conglomerate. Some thin beds of sand appear interbedded among these clays, 
but the sands nowhere seem continuous, appearing to form lenses. Occasionally the sands are indurated, and in places they occur in the form of bowlders scattered through the clay beds. The clays are sometimes thinly laminated or partially stratified, but are more frequently massive, and have a tendency to break into cuboidal blocks. The most important bed of clay in this group is a heavy bed of blue clay containing numerous concretions of earbonate of lime. The arrangement of the lime concretions gives to this clay the appearance of being partially stratified, as in most exposures seen these concretions lie in regular planes, and while for the greater part rouncled and nodular in form, in several sections they appear as flat concretions, sometimes being over a foot in length while not more than 2 or 3 inches in thickness.

Owing to the nature of the country underlain by these beds very few sections of any value are to be seen. Near Corrigan, on the Missouri, Kansas and Texas Railroad, in Polk County, laminated gypseous clays of this series occur, the thickness being a little over 6 feet. They also appear at Fleming, Chester, and other localities along this railroad. Near Fleming, in the eastern edge of Polk County, the following section appears in a railroad cutting:

Section near Fleming, Polk County.

1. Surface gray sand Feet.

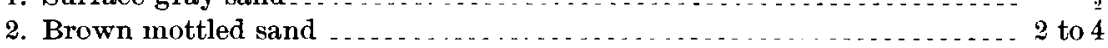

3. Gray stratified sand containing fossil palm wood in great abundance, with numerous quartz, jasper, and other pebbles; gravelly in some localities.

4. Blue clay partially stratified, but showing a tendency to break up into conchoidal blocks, and containing numerous nodules of calcareous matter.

5. Red clay having practically the same structure as No. 4, but without

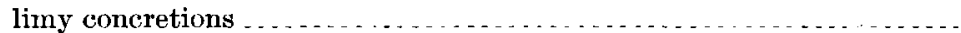

6. Yellow sand, visible

Five miles farther east the same clays appear underlying the gray sands, but in this place they appear as a partially stratified mottled clay containing nodules of lime. This mottled condition may be due to a mixture of the red and blue clays, as in none of the localities observed does there appear to be any real parting or line of division between the red and blue clays, except that the red does not contain calcareous nodules, which appear to be altogether confined to the blue clays. In the Rockland section the blue clays have a thickness of 20 feet, while the other Frio deposits in the same section consist of green, brown, and pale-blue clays having a thickness of 60 feet. In this locality the blue clays contain a small quantity of gypsum orystals in close association with the calcareous nodules, 
Between Roganville and Jasper, on the Gulf, Beaumont and Kansas City Railroad, in Jasper County, the blue clays, with lines of irregular stratification and ferruginous and calcareous concretions, appear in the cuttings for over 2 miles. In this locality the ferruginous and calcareous concretions appear to lie in definite lines, although broken in their longitudinal direction. These coneretions are flattened oval in shape and range in length from a few inches to 2 or 3 feet. 'These beds again appear between Newton and Burkeville, but in this locality are very generally covered by a ferruginous gravel containing considerable quantities of quartz and jasper and carnelian pebbles, and in several places indurated brown sand and ferruginous sandstone. In the neighborhood of Burkeville, in Newton County, they form a small prairie with black calcareous soil, and carry a thin seam of hard ferruginous sandstone containing such Eocene fossils as Ostrea alabamiensis, Cerithium sp., Venericardia, Crassatella antestriata Gabb, C. trapaquara Harris, Cardium, Astarte, Chama, Cytheria sp., Corbula sp., and Arca like mississippiensis Conr.

In Louisiand the calcareous blue clays are seen near Hornbeck in Vernon Parish, and at intervals along the Kansas City Southern Railway northward beyond Christie. A general section in the vicinity of Hornbeck shows the sequence of the beds to correspond with the Texas section.

\section{General section near Hornbeck, La.}

1. Surface brown, red, and mottled sands, in places weathering to a gray or brownish white.

2. Blue calcareous clays with some sandstone bowlders and ferruginous and calcareous concretions.

3. Gray sandstone.

Few wells have been drilled in the areas occupied by these Frio clays and the underground conditions are not well known. These beds are not usually water bearing, and when water is afforded by them it is generally unfit for use. When water is not obtainable from the surface creeks and smaller streams, or from shallow wells where the overlying sands overlap the clays, it is usually got from ponds or cisterns. The only wells drilled to any depth throughout the region are two recently drilled, prospecting for petroleum. These are widely separated, the first being situated 5 miles west of Valda in Polk County, Tex., and the second being about 12 miles southwest of Many, in Sabine Parish, La. 
Five miles west of Valda, in Polk County, a well drilled to a depth of 543 feet anve the following $\log$ :

Log of Dean well "s miles west of Valda, Polk Connty, Tex.

[Elevation, iss feet.]

\begin{tabular}{|c|c|c|c|c|}
\hline & Chararter of strata. & Thickness. & From- & To- \\
\hline 1 & Surface sands and gravels & Feet. & Fept. 0 & Feet. 22 \\
\hline 2 & White sand & 14 & 22 & 36 \\
\hline 3 & Strong water sand & 59 & 36 & 95 \\
\hline & Frio: & & & \\
\hline 4 & Clay with lime. & 45 & 95 & 140 \\
\hline 5 & Blue clay $\ldots \ldots \ldots$ & 20 & 140 & 160 \\
\hline 6 & Greenish clay with water at 195 feet $\ldots .$. & 35 & 160 & 195 \\
\hline 7 & Green shale $\ldots . . . . .$. & 35 & 195 & 230 \\
\hline 8 & Green shale with gravel & 10 & 230 & 240 \\
\hline & Fayette: & & & \\
\hline 9 & Quicksand & 11 & 240 & 251 \\
\hline 10 & Quicksand with lime and shells. & 33 & 251 & 284 \\
\hline 11 & Blne clay & 8 & 284 & 292 \\
\hline 12 & Green shale . . & 4 & 292 & 296 \\
\hline 13 & Shale $\ldots \ldots$ & 25 & 296 & 321 \\
\hline 14 & Soft green shale . . . . . . & 4 & 321 & 825 \\
\hline 15 & Green clay . . . . & 25 & 325 & 350 \\
\hline 16 & Green sand with pyrites & 34 & 350 & 384 \\
\hline 17 & Quicksand & 16 & 384 & 400 \\
\hline 18 & Green sand & 3 & 400 & 403 \\
\hline 19 & Blue clay ...... & 21 & 403 & 424 \\
\hline 20 & Green shale & 6 & 424 & 430 \\
\hline 21 & Blue clay . . . .... & 30 & 430 & 460 \\
\hline 22 & Shale rich in iron pyrites & 36 & 460 & 496 \\
\hline 23 & Dark shale $\ldots \ldots \ldots$ & 11 & 496 & 507 \\
\hline 24 & Light shale... & 13 & 507 & 520 \\
\hline 25 & Shale ........ & 10 & 520 & 530 \\
\hline 26 & Water sand $\ldots$ & 10 & 530 & 540 \\
\hline 27 & Gray sand $\ldots . . . . . .$. & 3 & 540 & 543 \\
\hline
\end{tabular}

This well has been drilled through the Frio clays into and almost through the Fayette sands. The Frio beds here apparently have a thickness of 145 feet, giving the Fayette beds a thickness of 303 feet. 
In T. 5 N., R. 12 W., Sabine Parish, I,a., the I). M. Foster well gives the following $\log$ to 630 feet.

Log of D. M. Foster well, in T. 5 N., R. 19 W., Sabine Parish, La.

\begin{tabular}{|c|c|c|c|c|}
\hline & Character of strata. & Thir:kness. & From- & To- \\
\hline & & Feet. & Feet. & Feet. \\
\hline 1 & Soil and clay & 18 & 0 & 18 \\
\hline 2 & Quicksand & 5 & 18 & 23 \\
\hline 3 & Blue clay changing to blue shale & 27 & 23 & 50 \\
\hline 4 & Blue limestone ........... & 2 & 50 & 52 \\
\hline 5 & $\begin{array}{l}\text { Blue clay with bowlders, first sign of oil at } 75 \\
\text { feet }\end{array}$ & 23 & 52 & 75 \\
\hline 6 & Blue shale, oil signs, and plenty of gas & 125 & 75 & 200 \\
\hline 7 & Lignite. . . . . . . . . . . & 5 & 200 & 205 \\
\hline 8 & Blue shale and gas $\ldots \ldots \ldots$ & 135 & 205 & 340 \\
\hline 9 & Brown gummy shale, oil on water & 10 & 340 & 350 \\
\hline 10 & Blue shale with oil and gas & 80 & 350 & 430 \\
\hline 11 & Slate-colored talcky rock $\ldots \ldots \ldots$ & 64 & 430 & 494 \\
\hline 12 & $\begin{array}{l}\text { Bluish-gray lime rock, very hard. Gas blew } \\
\text { out drillings. }\end{array}$ & 8 & 494 & 502 \\
\hline 13 & Tan-colored shale with yellow sand. & 40 & 502 & 542 \\
\hline 14 & Milky-white talcose rock $\ldots \ldots \ldots \ldots$ & 38 & 542 & 580 \\
\hline 15 & Blue shale with small white pebbles & 20 & 580 & 600 \\
\hline 16 & $\begin{array}{l}\text { Blue hard and flinty limestone: gas nnder this } \\
\text { rock }\end{array}$ & 4 & 600 & 604 \\
\hline 17 & $\begin{array}{l}\text { Shells and pebbles with strong indications of } \\
\text { oil and much gas }\end{array}$ & 26 & 604 & 630 \\
\hline
\end{tabular}

The location of this well is such that the Frio and Fayette sands are both absent owing to the extensive erosion that has taken place in this region. The gray sandstones occur both to the north and to the west of the well. These deposits are considered lignitic by Harris. ${ }^{a}$

The red and brown sands, clays, and sandy clays, and the blue and red laminated clays which go to make up the series of deposits succeeding the Frio elays have in this portion of the State an approximate width of from 25 to 30 miles, with a slight increase in width as they enter Louisiana. Along their northern border these sands, often bleached white or brownish yellow, overlap the underlying beds at many places for considerable distances, and in several localities completely obscure them. It is a question not yet satisfactorily answered, whether much of the grayish sands with fossil palmwood found in several localities and over considerable areas overlying the Frio beds should not be referred to this series of sands. The palm-bearing 
sands are in close connection with and in many places form a portion of the upper margin of these deposits, so that in all probability they will ultimately be found to be of the same age as these red and white sands, the difference in color being largely due to bleaching.

Along their southern edge the sands of this division merge so imperceptibly into the overlying Columbia sands that it is often difficult to say where the line should be drawn. To add to this difficulty, the upper sands of both Lafayette and Columbia have a tendency to weather to a dirty brown white, and few sections showing the contact are visible anywhere. Both series are water bearing to a high degree. The Columbia sands also contain a series of mottled brown and blue and brown and white sands, although no clays of this character have been observed.

In their general composition these beds resemble those toward the middle and western portion of the field, and it is hardly necessary to describe them here. Few sections of over 10 to 25 feet are obtainable anywhere throughout the area, and even wells scarcely ever exceed the latter depth. In the overlapping at Colmesneil the section shows a heavy deposit of brown sand containing nodules or inclusions of a pinkish-purple clay. These inclusions generally have a rounded or nodular form and appear to have been transported to their present location.

On the Missouri, Kansas and Texas Railroad, near Colmesneil, in Tyler County, these mottled sands appear to have a thickness of 10 feet and to overlie the fossiliferous cross-bedded sands. A section is as follows:

Section neur Colmesneil, Tyler County, Tex.

1. Gray sand

Fert. (i) $\operatorname{to} 8$

2. Mottled blue clay in small irregular elliptical poclets $\frac{1}{2}$ to 2

3. Mottled brown sand or soft sandstone broken into irregular blocks and containing lenticular patches of pale grayish-blne clay stratified at each

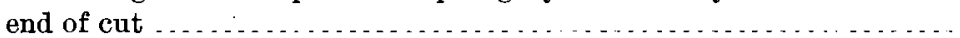

4. Gray cross-bedded sand, containing siliceous pebbles and fossil wood ...

Three and a half miles south of Colmesneil the contact between these brown sands and the underlying Frio clays may be seen in the following section:

Section $3 \frac{1}{2}$ miles south of Colmesneil, Tyler County, Tex.

1. Gray sandy soil

Feet.

2. Brown clayey sand

3. Brown laminated sand

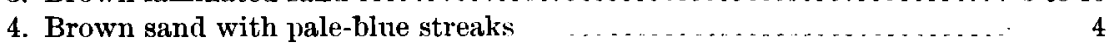

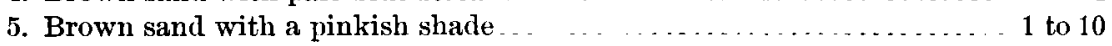

6. Thinly stratified blue clay and red sand _. . . . . . . . . . . . . . . 6

7. Blue clay with lime nodules (Frio) _...................... 6

The purplish-pink clays of the Iafayette extend eastwan through Jasper and Newton counties. In these locations, however, they 
assume a laminated condition and overlap the underlying Frio beds for several miles. In a laminated or mottled condition they also appear in Iuouisiana. In the Texas region they occur mottled in the railroad cuttings between Call and Roganville. North of Roganville they are laminated, and they lie in contact with the Frio calcareous clays near Walnut Creek a short distance south of Jasper. North of Burkeville, in Newton County, a section on the William Williams survey is as follows:

Section on William Williams survey, north of Burkeville, Neuton County, Tex.

1. Brownish sands weathering white on the higher grounds

Feet.

2. Variegated blue-brown and white clays in thinly laminated condition, colors

about equal in thickness and not exceeding half an inch $\ldots \ldots \ldots \ldots$

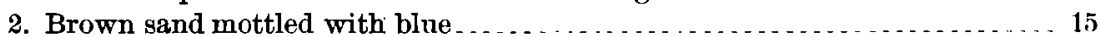

4. Thinly laminated white, brown, and blue clays similar to No. 2 . . . . . . 5

5. Ferruginous sandstone.

Near the town of Warren, in Tyler County, these beds are seen in contact with the Columbia sands in the following section in a well:

Section near Warren, Tyler County, Tex.

Feet.

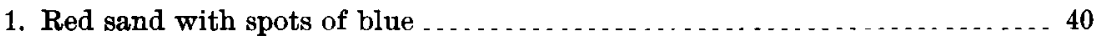

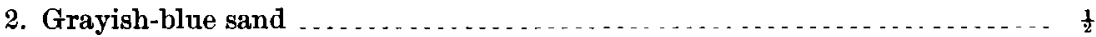

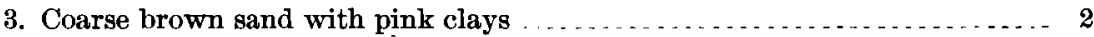

4. Pinkish-red sandstone with soft gray water sand $\ldots \ldots \ldots \ldots$

Few deep wells have been drilled in the regions occupied by these beds, and until now only one has been bored for petroleum-prospecting purposes.

Log of well arilled between Rush and Wolf creeks, about ? miles from Neches River, in Tyler County, Tex.

\begin{tabular}{|c|c|c|c|c|}
\hline & Character of strata. & Thickness. & From- & To- \\
\hline & & Fept. & Feet. & Fert. \\
\hline 1 & Clay & 8 & 0 & 8 \\
\hline 2 & Sand and gravel & 160 & 8 & 168 \\
\hline 3 & Clay & 4 & 168 & 172 \\
\hline 4 & Coarse sand with some gravel. & 428 & $1 \% 2$ & 600 \\
\hline$\overline{\mathbf{5}}$ & Blue shale with sight indications of oil and gas & 60 & 600 & 660 \\
\hline 6 & Blue sand & 164 & 660 & 824 \\
\hline
\end{tabular}

No division of this record is possible, but from the depth it must have been drilled through the Fayette sands, the last 224 feet at least apparently belonging to that division.

The eastern extension of the gray, white, bluish-gray, and yellow sands and accompanying yellow and blue clays of the Columbia finds 
its greatest development in this region. Beginning at the Trinity River these beds cover an area from 12 to 15 miles in width. In the Village Creek region this wilth has increased to about 30 miles, which is maintained as far east as the Sabine River, and apparently also along the line of the Kansas (ity Southern Railway in western Louisiana. Their areal extent has not been mapped in Louisiana, but they probably cover the greater portion of the territory generally classed as long leaf pine flats. The sands appear in T. 8 S., R. 9 W., along Hickory Branch, and also at Phillips Bluff on the Calcasieu River, in T. 8 S., R. $6 \mathrm{~W}$., and at a number of places between. They are also found in the Mendelsohn well about 2 miles north of Sulphur station, where they are reported to be 200 feet thick and underlain by gravel.

Closely associated with these sands and within a short distance from the surface the dark-blue clayey sands and clays give the water rising from them a peculiarly disagreeable fetid smell and taste, similar to that from decaying vegetable matter. Even boiling the water loes not destroy its peculiar taste. The surface material at these localities is usually dark gray in color and apparently almost impervious to water, and in wet weather remains covered with water for some time. These conclitions are noticeable at Nona, Kountze, and other places.

Several beds of clays are included in the division, but sands form the prevailing material. Where the Texas and New Orleans Railroarl crosses Village Creek these sands have a thickness of 20 to 30 feet and their texture and grayish color may be seen in the old ballast pits of the railroad. Similar bluffs oceur along the creek between this point and the crossing of the Gulf, Beaumont and Kansas City Railroad, in which locality the beds have a thickness of over 50 feet, and oceur as clear, white, fine sands overlain by brown and gray mottled sands, showing in some places ferruginous indurations resembling a brown sandstone.

In the Kountze region the sands have a thickness of 46 feet and over, as shown by well sections. Six miles west of the town the well dug for the water station of the Gulf, Colorado and Santa Fe Railroad shows a section of 46 f feet, of which the upper 10 feet are mottled and the lower 10 feet white sands. Twelve miles west of Kountze the same sands are shown to be over 30 feet thick.

These sands form the surface deposits covering the higher grounds in the neighborhood of Saratoga, Balson Prairie, in Hardin County, and Sour Iake. In the neighborhood of Saratoga they are yellowish white and contain considerable quantities of indurations of a soft sandstone. 'These sandstones or indurations also occur' in the neighborhood of Sour Iake and at several places along the Trinity River.

The Columbia sands form a very important member in the geologic section of the Beaumont oil fields, as the expensive drilling in this 
field is due chiefly to these beds. It is also due to their water-bearing qualities that the shallow wells drilled for water purposes in this region afford so steady and liberal a supply that extensive areas of rice lands are irrigated wholly from them.

The dip of these beds appears to be comparatively gentle, and while their thickness is very irregular, its average may be taken as approximately 200 feet.

Several deep wells have been drilled in the territory occupied by these sands, but very few of the logs are available. In the Saratoga oil field these sands appear in the IIooks well No. 1 to have a thickness of 173 feet and to be underlain by a blue and white clay. In the Libbie well, 3 miles farther west, the section of the well gives these sands a thickness of 135 feet. IIere they rest upon blue limy clay. 'The following is the log of this well:

Log of Libbie -Oil Company's well on the Joseph Blake tract, 3 miles west of Saratoga, Hardin County, Tex.

[Elevation, 90 feet.]

\begin{tabular}{|c|c|c|c|c|}
\hline & Character of strata. & Thickness. & From- & To- \\
\hline & & Feet. & Fiect. & Heet. \\
\hline 1 & Brown sandy elay $\ldots \ldots \ldots$ & 40 & 0 & 40 \\
\hline 2 & Gray sand $\ldots \ldots \ldots$ & 20 & 40 & 60 \\
\hline 3 & Gray sand with gas at 6 is feet & 10 & 60 & 70 \\
\hline 4 & Grayish-brown sand with gas .... & 10 & 70 & 80 \\
\hline 5 & Grayish-brown sand . . . . . . . & $5 \pi$ & 80 & 135 \\
\hline 6 & Blne clay with lime nodnles & 18 & 135 & 153 \\
\hline 7 & Grayish-blue sand with lime & 56 & 153 & 209 \\
\hline 8 & Grayish-white sand & 22 & 209 & 231 \\
\hline 9 & Gray sand. . & 39 & 231 & 270 \\
\hline 10 & Gray sandy clay $\ldots \ldots \ldots \ldots$ & 38 & $2 \pi 0$ & 308 \\
\hline 11 & Gray sand ... & 10 & 308 & 318 \\
\hline 12 & Clay & 20 & 318 & 338 \\
\hline 13 & $\begin{array}{l}\text { Gray rock with artesian water and small } \\
\text { quantities of oil immediately under the rock }\end{array}$ & 10 & 338 & 348 \\
\hline 14 & Sand with oil ............. & $\bar{j}$ & 348 & 353 \\
\hline 15 & Clay . . . . . . . & 5) & $3 \overline{3} 3$ & 358 \\
\hline 16 & Sand . & $17 i$ & 358 & 375 \\
\hline 17 & Clay . & $3 \pi$ & 375 & 412 \\
\hline 18 & Rock & $13 i$ & 412 & 425 \\
\hline 19 & Sand . & 86 & 425 & 511 \\
\hline 20 & Rock in thin layers with clay partings & 11 & 511 & 523 \\
\hline 21 & Rock and sand & 14 & 523 & 537 \\
\hline 22 & Sand and rock (bowlders) . .... & 48 & 537 & 585 \\
\hline
\end{tabular}


This well has since been drilled to a depth of 958 feet. During the drilling some oil and two streams of hot water were encountered. The first stream had a temperature of $100^{\circ}$ and was found at about 938 feet, and a second, hotter stream was encountered at 950 feet.

On the Bridges survey, about 3 miles northeast of Sour Lake, the Empire State Oil, Coal and Iron Company's well has been drilled to a depth of 1,284 feet.

Log of Empire State Oil, Coal and Iron Company's well, Isaac Bridges sumey, Hardin County, Tex.

[Elevation, 95 feet.]

\begin{tabular}{|c|c|c|c|c|}
\hline & Character of atrata. & Thickness. & From- & To-- \\
\hline & & Finet. & Freet. & Fieet. \\
\hline 1 & Fine yellow sand & 5 & 0 & 5 \\
\hline 2 & Sand and clay mixed .. & 10 & 5 & 15 \\
\hline 3 & Yellow sand... & 50 & 15 & 65 \\
\hline 4 & Dark-blue clay & 121 & 65 & 186 \\
\hline 5 & Blue sand & 15 & 186 & 201 \\
\hline 6 & Green clay $\ldots \ldots$ & 47 & 201 & 248 \\
\hline 7 & White sand $\ldots \ldots \ldots \ldots \ldots$ & 82 & 248 & 330 \\
\hline 8 & Blue clay & 53 & 330 & 383 \\
\hline 9 & White sand.... & 26 & 383 & 409 \\
\hline 10 & Blue clay & 54 & 409 & 463 \\
\hline 11 & Sand and wood & 13 & 463 & 476 \\
\hline 12 & Pale-blue clay...... & 537 & 476 & 1,013 \\
\hline 13 & Gravel & 7 & 1,013 & 1,020 \\
\hline 14 & Pale-red clay . & 16 & 1,020 & 1,036 \\
\hline 15 & Fragmentary rock ..... & 3 & 1,036 & 1,039 \\
\hline 16 & Blue clay . - & 116 & 1,039 & 1,155 \\
\hline 17 & Solid rock & 10 & 1,155 & 1,165 \\
\hline 18 & White sand ... & 21 & 1,165 & 1,186 \\
\hline 19 & Blue clay .... & 54 & 1,186 & 1,240 \\
\hline 20 & Blue clay with pyrites & 44 & 1,240 & 1,284 \\
\hline
\end{tabular}

In the Gold Thread well, southwest of Sour Lake, the blue elays with calcareous nodules are overlain by 160 feet of sand and are apparently the clays No. 12 of the above section.

It may also be noted that in the area occupied by these sands a number of salt licks and salt marshes occur. These extend across the country from the Trinity to the Calcasieu and cover areas from a few hundred yards to nearly 100 acres in extent. One of the largest of these marshes occurs in the immediate vicinity of Sour Lake, and has an area of approximately 100 acres; mother large one is located 2 miles west of the Libbie well at Saratoga, and has an area of about 60 acres. 
Few wells of which the records are available have been drilled in this eastern section of the Coastal Plain outside of the oil fields in the immediate vicinity of Beaumont. At the Gulf, Beaumont and Kansas City Railroad station the section shows 175 feet of clays and sands, as follows:

Section at Gulf, Beaumont and Kansas City Railroad station at Beaumont.

1. Clay

Feet.

2. Sand

3. Blue clay

4. Sand with shells -

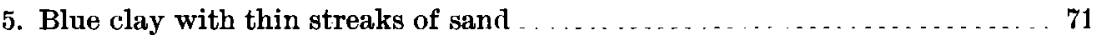

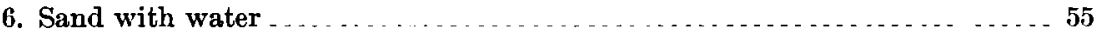

About 22 miles southwest of leaumont, on sec. 56, Texas and New Orleans Railroad lands, a well 104 feet deep shows 100 feet of mottled clay overlying 4 feet of white sand. The deep wells at Landrum, in Jefferson County, and near Winnie, in Chambers County, show the same conditions.

The following is the log of the Dixie Oil and Pipe Line Company's well, 3 miles north of Winnie, on the J. M. Durant league, in Chambers County.

Log of well of Dixie Oil and Pipe Line Company, 3 miles north of Winnie, Chambers County, Tex.

[Elevation, 26 feet.]

\begin{tabular}{|c|c|c|c|c|}
\hline & Character of strata. & Thickness. & From- & To- \\
\hline & & Feet. & Fet. & Feet. \\
\hline 1 & Soil . & 2 & 0 & 0 \\
\hline 2 & Yellow clay ( 2 -foot $\log$ at is feet) & 58 & 2 & 60 \\
\hline 3 & Water sand & 30 & 60 & 90 \\
\hline 4 & Yellow clay - . - & 90 & 90 & 180 \\
\hline 5 & Water sand .... & 124 & 180 & 304 \\
\hline 6 & Blue tough clay & 76 & 304 & 380 \\
\hline 7 & Water sand & 243 & 380 & 623 \\
\hline 8 & Tough clay ... & 212 & 693 & 835 \\
\hline 9 & Clay shells .. & 21 & 835 & 856 \\
\hline 10 & Blue tough clay & 20 & 856 & 876 \\
\hline 11 & Blue rock ......... & 20 & $8 \pi 6$ & $89 \pi$ \\
\hline 12 & Blue clay and shells & 163 & $89 \pi$ & 1,059 \\
\hline 13 & Gray sandstone .. & 1 & 1,059 & 1,060 \\
\hline 14 & Tough clay ..... & 318 & 1,060 & 1,378 \\
\hline 15 & Clay with shells & 62 & 1,378 & 1,440 \\
\hline 16 & Hard shale . & 20 & 1,440 & 1,460 \\
\hline 17 & Soft clay & 20 & 1,460 & 1,480 \\
\hline 18 & Gravel & 30 & 1,480 & 1,510 \\
\hline
\end{tabular}




\section{GRAVELS.}

Lying at the base of the Columbia beds, and apparently more intimately connected with them than with the underlying red and brown sands, there generally occurs a heavy bed of beach gravel. This gravel covers the whole of the territory occupied by the underlying red clays and sands, and in many places overlaps other underlying deposits as far north as the outerop of the Yegua clays. The gravel is irregularly deposited, being found in heavy deposits at some localities and in very small quantities at others, without any apparent cause for the irregularity. Along the northern border of the formation there appears an intermingling of the sands and pebbles, but within a very short distance southward the gravels have generally disappeared from the sand beds.

The pebbles forming these beds include clear and milky quartz, agate, jasper, carnelian, and some chalcedony, with considerable quantities of gray-blue and black chert, and some crystalline rock. The chert and some of the other pebbles have retained their angularity to a considerable extent, which rould lead to the conclusion that they have not traveled any great distance. Most of the others are rounded and waterworn. While in some places the pebbles occur mixed with sand or in an unconsolidated gravelly condition throughout the greater portion of the field, as especially shown in the records of the deeper well drillings, the pebbles are cemented by a white calcareous matrix and form a conglomerate of variable hardness.

The actual areal extent of these gravels and conglomerates is not known with any certainty, but they appear to be coextensive with the Columbia beds and with them to pass under the overlying clays. They are found in one or the other form in every well sufficiently deep throughout the whole corst country from the Mississippi westward to the Guadalupe River, and probably even farther west.

In almost every well drilled or dug down to them these gravels are shown to lie between the two sands. In thickness they vary from 10 to 80 feet; their greatest thickness as well as greatest areal development is toward the eastern or Mississippi end, and they gradually thin out toward the west and southwest. They also lie at a much greater depth in the western than in the eastern portion of the Coastal Plain. 'Throughout the parishes of St. Marys, New Iberia, and St. Martins they lie at depths ranging from 94 feet at Anse la Butte to 150 feet 3 miles southwest of Jeanerette, ${ }^{a}$ where they have a thickness of 64 to 90 feet. In Arcadia and Vermilion they have thicknesses of from 41 to 80 feet, and lie at depths ranging from 140 to 170 feet in Arcadia Parish and from 100 to 170 feet in Vermilion. In this region it is evident from Mr. Clendenning's sections, as well as those made by Mr. Hager, ${ }^{b}$ that these gravels underlie the clays 
succeeding the Columbia beds. The position of these gravels with reference to the overlying deposits may be seen in the following logs:

Log of Pioneer Oil Company's well at Anse la Butte, La.

[Elevation, 45 feet.]

\begin{tabular}{|c|c|c|c|c|}
\hline & Charactor of strata. & Thickness. & From- & To- \\
\hline & & Feet. & Feet. & Feet. \\
\hline 1 & Red clay - & 36 & 0 & 36 \\
\hline 2 & Red sand . & 15 & 36 & 51 \\
\hline 3 & Gray sand ..... & 23 & 51 & 74 \\
\hline 4 & Gravel and gray sand & 40 & 74 & 114 \\
\hline $\mathbf{5}$ & Gravel with wood & 40 & 114 & 154 \\
\hline 6 & Sandstone $\ldots$ & 20 & 154 & 174 \\
\hline 7 & Light gravel & 16 & 174 & 190 \\
\hline 8 & Sandstone $\ldots \ldots$ & 4 & 190 & 194 \\
\hline$\partial$ & Gravel and sand. & 26 & 194 & 220 \\
\hline 10 & Rock & 14 & 220 & 234 \\
\hline 11 & Heavy gravel ....... & 16 & 234 & 250 \\
\hline 12 & Sand, gravel, and oil & 35 & 250 & 285 \\
\hline 13 & Coarse gravel . & 43 & 285 & 328 \\
\hline 14 & Sand . . . . . . & 5 & 328 & 333 \\
\hline 15 & Sandstone . . . . . . . . & 1 & 333 & 334 \\
\hline 16 & Sand and blue clay & 28 & 334 & 362 \\
\hline 17 & Sand and gravel & 39 & 362 & 394 \\
\hline 18 & Gravel & 6 & 394 & 400 \\
\hline 19 & Sand and clay ..... & 20 & 400 & 420 \\
\hline 20 & Blue clay $\ldots . . . . .$. & 71 & 420 & 491 \\
\hline 21 & Rock, 18 inches sandstone with oil & $1 \frac{1}{2}$ & 491 & $492 \frac{1}{2}$ \\
\hline 22 & Blue shale & $42 \frac{1}{2}$ & $492 \frac{1}{2}$ & 535. \\
\hline 23 & Sandstone. . . . . . . . . & 43 & 585 & 578 \\
\hline 24 & White sand ........ & 51 & $5: 8$ & 629 \\
\hline 25 & Rock with oil, flinty . & 21 & 629 & 650 \\
\hline 26 & Hardpan and clay .... & 54 & 650 & 704 \\
\hline 27 & Blue clay & 446 & 704 & 1,150 \\
\hline 28 & Blue sand _ & 50 & 1,150 & 1,200 \\
\hline 29 & Rock. .... . & 20 & 1,200 & 1,220 \\
\hline 30 & Blue clay . & 14 & 1,220 & 1,234 \\
\hline 31 & Rock $\ldots \ldots$ & 26 & 1,234 & 1,260 \\
\hline 32 & Oil sand and gravel, with oil and salt water & 1 & 1,260 & $1,261+$ \\
\hline
\end{tabular}

Another well in the vicinity gave gravels at depths between 40 and 50 feet, with another bed 50 feet thick between 150 and 200 feet. 
Among the shallow wells the following sections show near Abbeville, in Vermilion Parish, La.:

Section near Abbeville, Vermilion Parish, La.

1. Yellow clay ... . . . . .

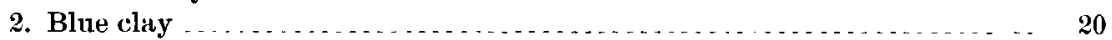

3. Sand .................. 30

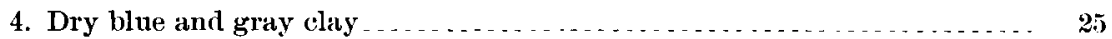

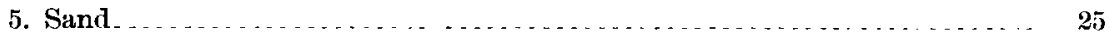

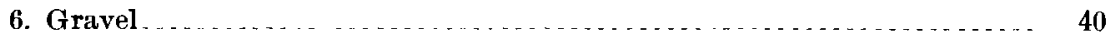

In Arcarlia Parish, 12 miles north of Crowley, a section is as follows: Section 1.2 miles north of Crowley, Areadia Parish, La.

1. Gray clay

2. Blue clay 50

3. Gray sand

4. Gravel . -

At Welsh, in Calcasieu, a well gives a section as follows: ${ }^{a}$

Section at Welsh, Calcasieu Parish, La.

1. Soil.

2. Mottled clay

3. Red quicksand $\ldots \ldots \ldots \ldots n \ldots$

4. Chalky clay ........ 50

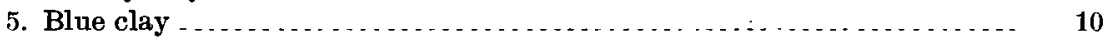

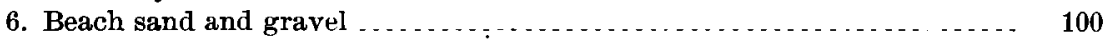

In the western portion of Louisiana these gravels lie at a considerably greater depth and are somewhat thinner than in the eastern portion of the field. At Lake Charles the Watkins well No. 1 shows 44 feet of gravels mixed with sand, underlying sand, at a depth of 400 feet. $\Lambda t$ depths of 550 and 600 feet gravels also occur in this well, which otherwise shows nothing but sands and clays throughout its entire 2,400 feet. At Sulphur the gravels appear at 300 feet and are 45 feet thick, and at Vinton, about 12 miles to the southwest, the gravel beds are reached at a depth of 440 feet, having in that locality a thickness of 25 feet. ITere they are strong water-bearing beds.

In the 'Texas regions the gravels disappear in the vicinity of IIillister, in Tyler County, on the Texas and New Orleans Railroad. This is the farthest south at which the siliceous pebbles have been seen. They also pass under the Columbia sands to the west in the neighborhood of Shepherd, in San Jacinto County, on the Houston, East and West Texas Railway. They are, however, reported from every well drilled to the south of the Columbia outcrop. On Spindletop they appear in the Higgins well No. 2 at 120 feet. In the ariginal Higgins well of 
1893 the black cherty gravel was passed at 200 feet. In the Lucas well and the IIiggins well No. 1 the gravels oceur at 245 feet, in the Geyser Development well at 295 feet, and in the Treadway at 454 feet. Westward the Texas Gulf Coast Land and Oil Company passed through 40 feet of conglomerate at a depth of 360 feet. In the Bryan Ileights well near Velasco, in Brazoria County, the gravels were reached at a depth of 735 feet. At. I)amon Mound the gravels are associated with shells at 171 feet in the IIerndon well and at 255 feet in the Guffey No. 1, about a mile to the northwest. In this latter well they have a thickness of 18 feet, while in the IIerndon well they show only 6 feet. The thickness shown in the Velasco well is over 10 feet, but the actual thickness is not known.

It appears from the above well records that throughout the whole of the Texas region these gravel beds are much thinner than in Louisiana. In the Texas wells they range from 10 to 26 feet, except in the Gulf Coast well as given above.

$\Lambda t$ the time of the deposition of these gravels the laud must have stood at a comparatively slight elevation above the level of the soa and have had only a moderate inclination seaward, since their dip as shown by the borings does not at present exceed o feet per mile.

The determination of the age of these gravels and their correlation with similar deposits elsewhere are somewhat difficult, and involve questions which can not be definitely answered without arefully tracing the beds over extensive areas toward the northeast. Whatever their age, whether late 'Tertiary or early Pleistocene, they should probably be correlated with the Plateau gravels of central Texas and the Uvalde formation of southwestern Texas, as describer by Hill, and with the latest episode of the Iafayette formation east of the Mississippi, as described by MeGee, or, more properly, the earliest Columbia. Since these deposits of coarse material were probably laid down at the margin of a transgressing sea, they can not be regarded as strictly contemporaneous, except along lines parallel to the former sea margin.

Like their associated overlying sand beds, the presence, thickness, and position of these gravels are of the utmost importance to the well driller. They are usually strongly water bearing, and the driller after water is almost certain to get a considerable supply when he reaches them. To the oil-well driller these gravels often offer a strong barrier to his further progress. The rotary method of drilling is not adapted to raising such heavy material to the surface, and more than one well has been lost because the driller was not prepared to handle this gravel when reached. Where the gravel beds are heary the driving of the casing has usually to be resorted to. This entails considerable risk, and often the loss of the well by damage to the casing.

Bull, 212-03 - 5 


\section{CHANGES OF LEVEL DURING DEPOSITION OF COASTAL PLAIN} FORMATIONS.

At the elose of the Eocene the Frio clays occupied a broad belt above sea level and formed the coast line of this portion of the continent. The coast had been rising for a long time, and then remained practically stationary at a comparatively high level long enough to permit of the extensive erosion to which the Frio beds have been subjected, and at the same time to permit the deposition of some 900 to 1,000 feet of sandstones and limestones in the comparatively shallow water offshore. During the deposition of these sandstones and limestones there appear to have been considerable oseillations, the land sinking toward the east and rising to the west. It formed a low sandy shore, with broad stretches covered at intervals by tide.

Following the deposition of these sandstones the land began to sink again, and continued sinking until a depth of at least 500 feet was reached throughout southeastern Texas and southwestern Louisiana. This sinking enabled the deposits then being laid down to cover a very wide stretch, extencling as far northward as the old Cretaceous shore line in the Texas areas and in some places overlapping it. These deposits, however, did not completely submerge the whole of the Eocene of Texas. Some of the higher divides appear to have been above water at that time, as they are not covered with the brown sands and sandy clays of these later deposits and there are no evidences of their ever laving been covered. It was during this period that the brown sands, sandy clays, and gravels of the Lafayette were laid down.

Another change took place and the land again began to rise. The elevation was apparently at a moro rapid rate than the previous depression. This elevation gradually increased until the present shore line in the 'Texas areas had an approximate elevation of 400 feet and the Jafayette shore lay at least 150 miles seaward.

This elevation of the land continued for a period long enough to permit of the removal of these sands from a very large area and the formation of wide channels along the courses of the rivers and the deposition of the heavy beds of gravel which now everywhere cover the lower levels of the country.

During this period the rivers then in existence had extended their channels seaward, and the Brazos, Trinity, and Sabine united in their lower reaches and flowed for miles through a single channel.

Following this high continental condition was another depression, and the brown and gray sands and sandy clays of the Columbia epoch were deposited. Again the sea enroached upon the land, but not nearly to the extent it had done during the preceding Lafayette, as the present shore line sank only to a depth of about 100 feet bolow sea lerel. 
This sinking appears to have been accompanied with a series of oscillations or tilting of the land, and it was probably during this period that a considerable part of the flexing or faulting of the beds which resulted in the formation of the anticlines, or lines of domeshaped elevations, took place.

Again the sea began to recede, and the Columbia sands were raised above the level of the water. IIigh-level conditions again prevailed, and there followed a period of nearly stationary conditions with only a few slight oscillations. The flexing or folding that was active in the preceding period evidently continued through this also, and the domes were raised still higher, until probably their crests approached the surface of the water and formed reefs and islands oceupied by such marine shallow-water life as the Ostrea.

The land subsequently tilted seaward, and it was during this time that the disposition of the Beaumont clays took place. These clays and muddy leposits associated with them were evidently laid down in water comparatively shallow and subject to prolonged periods of alternate marsh and lake conditions. They are very generally filled with stumps and logs, and at a depth of from 45 to 100 feet appear to have had a period of vicissitudes very closely approaching those to which the overflow bottom lands of many of the present rivers are subject. Marshy conditions doubtless occurred, and during that time the cypress appears to have flourished. Floods brought down from the higher grounds the dead and fallen wood and other débris, and the small streams and rivers, upon entering the comparatively quiet waters covering these flats, dropped their burdens, which were afterwards assorted and distributed by the tide.

A further slight rise took place and these clays became dry land, and the shore line was moved much farther southward, until it probably stood about where the Trinity shoals are now situated. The final change followed this elevation and present conditions were inaugurated; the sea again began to encroach slowly upon the land, which it appears to be doing at the present time, at least in the region eastward of the Trinity, though west of that river the land is slowly rising.

It appears that the area between the Brazos and Guadalupe rivers was less affected by these changes of level, and that even in Lafayette times this area formed a ridge extending seaward, and that throughout all the fluctuations it maintained a comparatively higher altitude than the regions on either side.

Evidence pointing to the same conclusion is the presence of beds belonging to the Miocene and early Pliocene at the surface throughout several portions of the margin of the western Coastal Plain, while these beds do not appear anywhere throughout the eastern end, but lie buried to a depth of several hundred feet. 


\section{GEOIOGY OF' 'TIE OIL I'OOLS.}

\section{ENUMERATION OF OIL DISTRICTS.}

The foregoing aceount of the Gulf Coastal I'ain has been given in some detail in order that the geologic environment of the oil pools might be readily understood. The latter, so far as they are now known, occupy an extremely small fraction of the region described. Excepting the Spindletop pool, their limits are in no case defined with any degree of accuracy. It is probable that the actually productive territory will be confined to small areas similar to the Spindletop pool, which may vary in extent from 200 to 2,000 acres.

The clistricts which at present give promise of productiveness, and which will be described in the order given, are the following:

In Texas:

1. Beaunont district, including Spindletop.

2. Port Arthur-Sibine Pass district.

3. Sour Lake district.

4. Saratoga district.

5. Dayton district.

6. High Island district.

7. Columbia district.

४. Velasco district.

In Louisiana:

9. Jennings district.

10. Anse la Butte district.

11. Sulphur district. .

12. Vinton district.

13. Hackberry Island district.

14. Minor Louisiana localities.

It is not implied that the districts mentioned above include all the productive territory in the Texas-Louisiana field. It will readily be understood from the geologic conditions already described that prediction in this field is exceptionally hazardous. On another page the most favorable regions for prospecting are indicated, but it is entirely within the range of possibility that elsewhere than in these apparently favorable localities oil may be found in commercial quantities. All that can be said with regard to the greater part of this field is that no evidence of the existence of such deposits has yet appeared, and the only way in which their presence or absence can be definitely determined is by systematic and expensive drilling.

\section{BEAUMONT DISTRICT.}

This district includes the small area which is actually productive, generally known as Spindletop, and a much larger surrounding area in which active prospecting has been going on for more than a year, but which has not yet developed any paying wells. The Spindletop pool will first be described and then the surrounding unproductive portion of the district. 


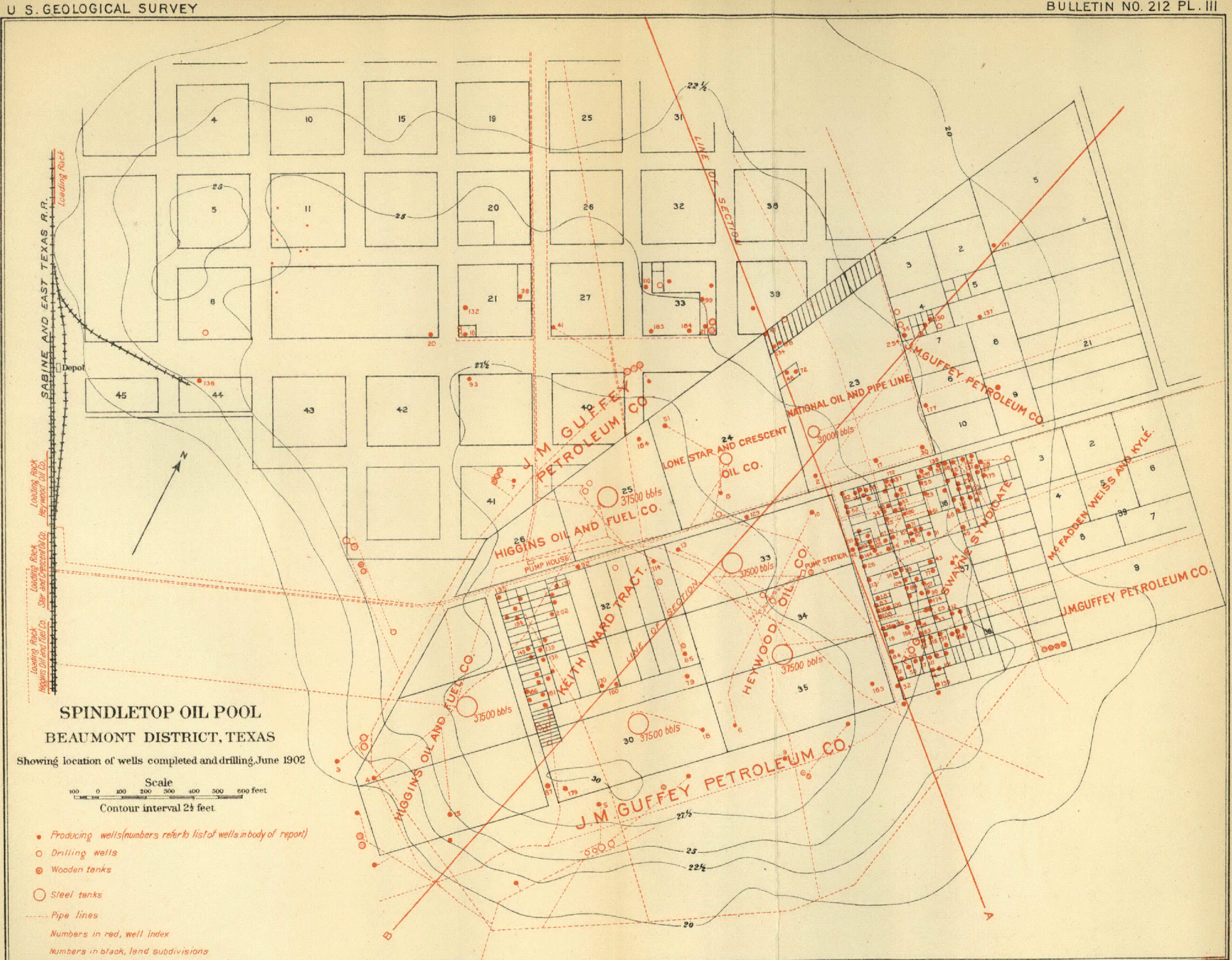



SPINDLETOP POOL.

JIMITS OF TILE POOI.

The delimitation of this pool, as shown on the map (fig. 3, p. $8(i)$, has been practically completed by a sories of borings made on almost every side of the heights anch in close proximity to them. Ontside of the line indicating the limits of the pool these borings have in every instance proved to be dry holes. To the south two wells-the McFadden oil and gas well (No. 40) and the IIebert well (No 39), drilled to depthis of 1,500 and 2,000 feet, respectively-have been abandoned. On the east the Gober No. 1 (No. 37), 1,840 feet; the Stribling (No. 36), 1,530 feet; and a little farther east the United States No. 7 (well No. 38), 2,100 feet, have all been abandoned as dry. Northeast and north there are several wells of different, depths, but most of these have been abandoned as dry. Among them are the Bayou City (No. 12), 2,010 feet; the 'Treadway (No. 18), 1,800 feet; the Allyne (No. 13), 2,015 feet; the Chicago Crulle (No. 21), 1,050 feet; and the T. and N. O. Company's well (No. 17) - the celebrated "Keiser-Kelly"2,160 feet. In the same region the Slaughter-Masterson (No. 22) and the Harby (No. 4) wells are drilling. 'The Slaughter-Masterson is at present (May, 1902) one of the deepest wells in the field, being at a depth of more than 2,250 feet. The IIarby has reached a depth of 1,840 feet.

On the west and southwest the Acme (No. 45), 1,680 feet; the Trenton Rock (No. 30), 1,500 feet; the Buffalo (No. 28), 1,400 feet, and the Federal Crude (No. 29), 2,350 feet, have been abandoned. A test well is now being made of the Federal Crude, and arrangements have been made to drill to 3,000 feet if nocessary.

These wells, all of which go to considerably greater depths than any of those within the productive territory, practically limit the Spindletop pool to an oval area about 3,000 feet in length and 2,700 feet in width. This gives a total productive area of about 200 acres. The longer axis of the pool lies approximately southwest and northeast.

CHARACTER OF OVERLYING BEDS.

Notwithstanding the great number of wells which have been drilled on Spindletop, it is somewhat difficult to obtain accurate detailed well records. While the drillers and owners can supply the depth at which oil was found, very few appear to have kept anything like a reliable log. The general consensus of opinion, based on statements of the drillers and on the few logs obtainable, appears to be that the first 500 feet of strata from the surface are composed of sands and clays, with occasional deposits of shells and thin, irregular seams of sandstone. At depths varying from 500 to 600 feet many of the wells have passed through limestone and sandstone, which from their irregularity and fractured condition are looked upon as large bowlders. 
From their size and position it is, however, more probable that these so-called bowlders are fractured beds brought into their present condition by the uplift of the dome. Following these limestones is another series of clays, sands, shells, and limestones extending down to the so-called cap rock, which is a limestone of the same age as the overlying beds: It is of variable thickness, ranging from 3 to 50 feet. Throughout the beds, from the depth of 500 feet downward to the cap rock, occasional oil-bearing horizons are met with. Some of these exhibit considerable strength, and have in several wells been heavy enough to interfere with the drilling. Very heavy gas pressures have also been met with between the 500-foot sandstone and the cap rock.

'The depths at which the cap rock has been struck varies between 900 and 1,000 feet. A few have fallen below the 900-foot mark, while some have slightly exceeded 1,000 feet.

CHARACTER OF THE OIL ROCK.

The oil rock is a dolomite, fairly uniform in composition and structure. It is not a pure dolomite, but contains a considerable preponderance of calcium over magnesium carbonate, sufficient to canse it to effervesce rather briskly in cold dilute hydrochloric acid.

The most striking characteristic of the oil rock is its extreme porosity. In some wells, under the pressure of the escaping oil and gas the rock was broken down and large quantities were carried up the casing to the surface, appearing as coarse sand or gravel, the fragments varying from a very small fraction of an inch to an inch in diameter. In addition to this disintegrated rock many large fragments were thrown out by the gushing oil, their size being limited only by the size of the casing. These fragments always have a porous structure, and even their most compact portions, as shown under the microscope, contain a larger proportion of vacant space than most of the oil-bearing Trenton dolomite of Ohio and Indiana. In addition to these minute spaces between the crystals composing the rock, such as characterize ordinary oil sands, the rock contains many large cavities, certainly as much as an inch across and probably very much more. Naturally the maximum size of these cavities can not be determined from the rock fragments which form their walls, but there appears to be nothing unreasonable in the supposition that they may in some cases be measured in feet rather than in inches. Reports from drillers of tools dropping several feet after passing through the eap rock are in support of this view, though such reports are always to be accepted with caution.

The cavities in the oil rock are always lined with a layer of crystalline calcite, the free ends of the crystals extending into the open spaces. It is evident, therefore, that the latest action of the circulating liquid in these cavities has been that of deposition rather than of solution, although the latter must have been at one period extremely 
active. From the samples of the oil rock thus far obtained it is impossible to make any accurate determination of the relative volume of the open cavities, but the proportion can hardly be less than onethird, and may be somewhat more when account is taken also of the minute spaces between the crystal grains of the more compact portions of the rock.

The exceptional character of this oil rock explains in a measure the remarkable features of the Spindletop pool. Its extreme porosity favors the storage of a very large volume of oil, and also favors the yielding of this oil with great rapidity when the reservoir is tapped. It also favors the early exhaustion of the oil in the pool and its rapid replacement by the underlying brine.

From some of the wells, along with the dolomite large pieces of crystalline gypsum or selenite have been thrown out by the escaping oil. Their surfaces are always deeply corroded, giving evidence that they have been subjected to the action of some solvent.

Another important accessory mineral in the oil rock is native sulphur. Large erystals, an inch or more in length, have been obtained from many of the wells, and it is reported by several of the drillers that the oil rock is overlain by a heavy bed of sulphur. In the National Oil and Pipe Line well No. 1 this sulphur deposit is claimed to have a thickness of 40 feet. A large amount of material was brought out by the bailer, consisting of coarse sand, about 25 per cent of which was pure sulphur and the remainder granular dolomite and erystalline calcite. The grains are slightly rounded, probably by the friction of the bailer, and the sand is doubtless derived from the disintegration of a soft dolomite in which the sulphur crystals are embedred. In wells Nos. 2 and 3 of the same company a similar bed of pure sulphur is reported, separated from the oil rock by from 23 to 26 feet of sulphur-bearing sand. In the IIeywood wells Nos. 1 and 2 this bed of sulphur is also recorded, and there is said to be about 70 feet of it in Gladys well No. 3. $\Lambda$ similar bed of sulphur is claimed to underlie 10 feet of oil sand in the Iliggins well No. 1, but does not appear in Higgins well No. 2 nor in the Lucas well. It is also absent in the Geyser Oil and Development well on the north side of the hill.

\section{BEDG UNDERI.YING THE OIL ROCK.}

While the actual thickness of the oil-bearing beds throughout the greater part of the pool is undetermined, certain minimum thicknesses are known, as wells have been drilled as deep as 77 feet into these beds, and one well has gone down to a depth of 96 feet without passing through the oil rock.

Only a few wells on Spindletop have passed entirely through the oil rock, and there is therefore little information available concerning the character of the underlying rocks. The Robertson well, toward the western side of the pool, is reported to have passed through 50 
feet of oil rock and a rlistance of 100 feet into a white limestone underneath. No samples of the latter were obtained, but from the description given by the driller it is regarded as at least probable that this bed is gypsum rather than limestone. The thickness of 50 feet for the oil rock indicates that the bed thins out toward the western edge of the pool.

The IIiggins No. 3 well passed througl 19 feet of oil rock at a depth of s5n fect. This was cased off and the drilling continued, with a view of ketermining whether or not there were any lower oil-bearing horizons. A second bed of oil rock was reported, 21 feet in thickness, below which the drill penetrated 70 feet of rock similar to that found in the bottom of the Robertson well. The Higgins Company put down another test well in the immediate vicinity of the No. 3, which, after passing through the oil rock, entered gypsum at about 1,040 feet in depth, and at 1,650 feet encountered salt, which continued to a depth of 1,960 feet, where the drilling stopped. The entire thickness of the salt is not known.

STRUCTURE OF SPINDLETOP POOL.

In the records of wells drilled on Spindletop the only horizon which can be identified with any degree of certainty is the oil rock itself. It is generally supposed that the so-called cap rock on which the casing is set represents the same stratum in every case, but this is by no means certain. Each driller decides when he has reached a bed sufficiently solid to set his casing, and this point probably varies rather widely, which explains in some measure the differences in reported depth to the cap rock in closely adjoining wells, and some, at least, of the apparent irregularities in the surface of the oil rock. Eliminating these minor irregularities the structure of the pool appears to be that of a dome or quaquaversal with steep sides and rather flat summit. The dome in the beds at the oil-bearing horizon coincides closely with the surface elevation, Spindletop Hill, although the dips of the beds around the margin of the dome are much steeper than the corresponding slopes of the land surface.

The accompanying sections across the pool on the lines shown on the map, nearly at right angles to one another, show the structure so far as it has been made out. Outside of the producing territory the numerous wells which have been put down, some to depths of more than 2,000 feet, fail to reach any stratum which can definitely be correlated with the "cap rock." Hence the lines indicating structure can be extended beyond the limits of the field only by inference. All the indications are, however, that the dip away from the dome is very abrupt, possibly more so than shown on the sections. These sections are drawn upon a natural scale-that is, the horizontal and vertical scales are the same-and the lines represent the actual slopes of the beds so far as they can be determined from data now in hand. 


$$
\text { Aroblywe }
$$



The section $\mathbf{A}-\mathbf{A}$ crosses the eastern side of the hill, its direction being N. $48^{\circ} \mathrm{W}$., coinciding very nearly with the southwestern boundary of the Hogg-Swayne tract. Along this line the arching of the strata is not very striking, although there is considerable ascent from the Guffey No. 9 to the National No. 1, and then a slight descent to the Geyser-Kaltenbach, which is the last well in this part of the pool from

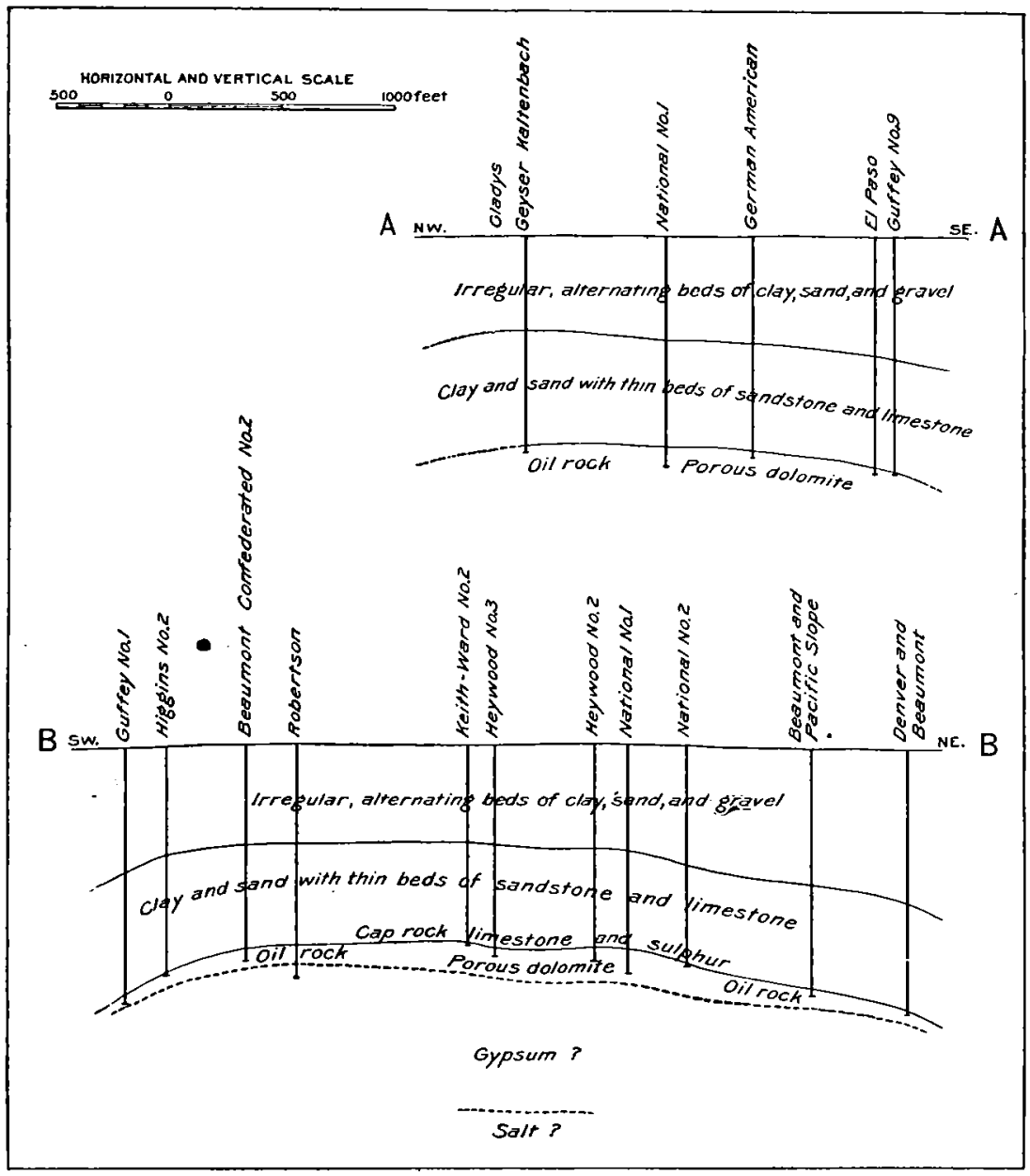

FIG. 2.-Sections of Spindletop oil pool. (See map, Pl. III.)

which a record was obtained. Continuing the line about 2,000 feet beyond the Geyser-Kaltenbach, the Chicago Crude well is reached. This is a dry hole, and to a depth of 2,100 feet encountered nothing which could be identified as the oil-bearing bed of the Spindletop pool. It is evident, therefore, that the oil rock either dips very rapidly toward the north between these two wells or does not retain its peculiar characteristics beyond the limits of the productive terri- 
tory. Or the failure to find the oil rock in any of the wells outside the proved field may be due to a combination of these causes.

The second section, $\mathrm{B}-\mathrm{B}$, is upon a line $\mathrm{N} .15^{\circ} \mathrm{E}$., coinciding approximately with the long axis of the pool. It shows very clearly the arching of the strata in this direction. About 1,100 feet beyond the Denver and Beaumont well, toward the northeast, is the Big Jumbo, a dry hole, which stopped, after passing 14 feet into limestone, at a depth of 2,000 feet. This is not certainly identified as either the cap or oil rock, but probably represents approximately the horizon of the latter, which would indicate a steep dip, about $40^{\circ}$, immediately beyond the margin of the productive territory. The same indications of very steep dips away from the pool are afforded by all the dry wells which have been drilled immediately about its margin.

WELL SECTIONS.

Several sections of wells in the Spindletop pool have already been published, notably that of the original Iucas well. Considering the number of wells drilled in this small area, very few logs having any degree of accuracy are obtainable. The method employed in drilling - by means of the rotary drill, which is described on a subsequent page-loes not favor the keeping of accurate records. The only means which the driller has of determining the character of the material which he is passing through is its relative hardness and the material brought up by the return-water flow. By the caving in of the sides of the hole below the casing any soft material which has been passed through and not cased off may be brought up, and not necessarily represent the bed at the bottom of the well, but a mixture of materials from various depths. A few logs have been kept with as much accuracy as the method of drilling permitted, and two of these will be given, chiefly to indicate the extreme variability of the materials overlying the oil horizon.

Log of the Geyser-Kaltenbach well, block 23, Spindletop.

[Elevation, 25 feet.]




Log of the Geyser-Kaltenbach well, block 23, Spindletop-Continued.

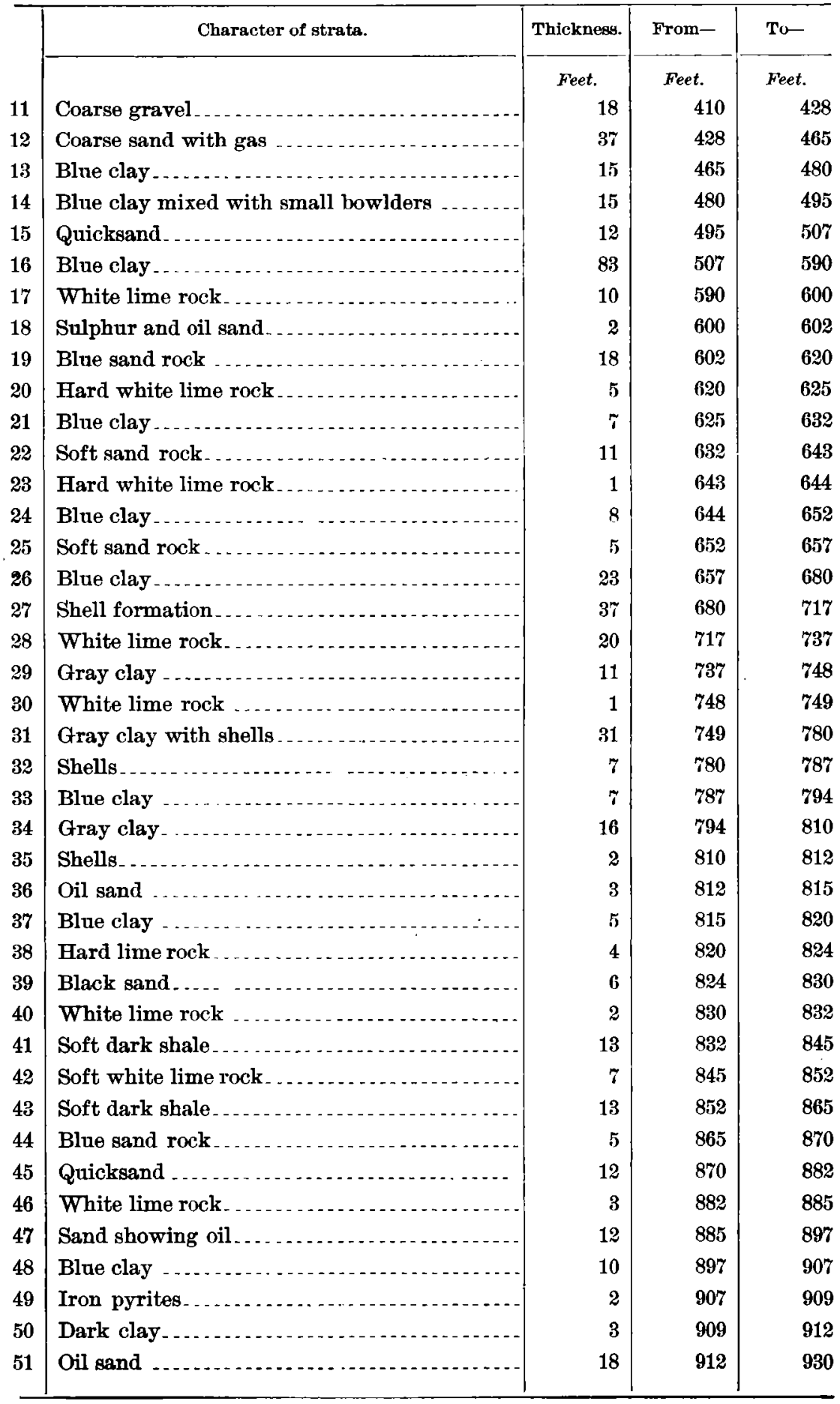


Log of Higgins well No. 2, near southern margin of Spindletop pool.

[Elevation, 25 feet.]

\begin{tabular}{|c|c|c|c|c|}
\hline & Character of strata. & Thickness. & From- & To- \\
\hline & & Feet. & Feet. & Feet. \\
\hline 1 & Soil, black sandy loam & $\frac{2}{3}$ & 0 & t \\
\hline 2 & Yellow clay with red streaks. & $3 \frac{1}{3}$ & $\frac{8}{3}$ & 4 \\
\hline 3 & Blue clay with limy concretions. & 12 & 4 & 16 \\
\hline 4 & Bluish-gray sand ......... & 6 & 16 & 22 \\
\hline 5 & Yellowish-colored clay with lime & 8 & 22 & 30 \\
\hline 6 & Dark-blue clay with some lime and shells. & 10 & 30 & 40 \\
\hline 7 & Gray sand $\ldots \ldots$ & 16 & 40 & 56 \\
\hline 8 & Blue sand . ... & 13 & 56 & 69 \\
\hline 9 & Blue clay with pyrites & 51 & 69 & 120 \\
\hline 10 & Blue sand with some clay and small pebbles. & 26 & 120 & 146 \\
\hline 11 & Fine bluish-gray sand & 10 & 146 & 156 \\
\hline 12 & Fine gray sand. & 31 & 156 & 187 \\
\hline 13 & Fine gray sand with black specks .. & 10 & 187 & 197 \\
\hline 14 & Bluish-tinted gray sand . . & 65 & 197 & 262 \\
\hline 15 & Dark-gray sand with black specks. & 9 & 262 & 271 \\
\hline 16 & Fine dark-gray sand. & 44 & 271 & 315 \\
\hline 17 & Fine grayish-tinted sand ... . & 35 & 315 & 350 \\
\hline 18 & Fine grayish-green sand . .... & 50 & 350 & 400 \\
\hline 19 & Fine brownish-gray sand ..... & 40 & 400 & 440 \\
\hline 20 & Fine brown sand with shells $\ldots . . . .$. & 30 & 440 & 470 \\
\hline 21 & Fine brown sand with broken shells & 21 & 470 & 491 \\
\hline 22 & Coarse blue sand with broken shells. . & 9 & 491 & 500 \\
\hline 23 & Very fine muddy sand $\ldots \ldots$ & $4 \tau$ & 500 & 547 \\
\hline 24 & Very fine bluish-gray sand $\ldots$ & 17 & 547 & 564 \\
\hline 25 & Very fine gray sand with bluish tint .... . & 48 & 564 & 612 \\
\hline 26 & Fine gray sand with bluish tint $\ldots \ldots \ldots$ & 12 & 612 & 624 \\
\hline 27 & Fine sandy clay (fish bones at 628 feet) & 42 & 624 & 666 \\
\hline 28 & Fine blue sandy clay $\ldots$ & 6 & 666 & 672 \\
\hline 29 & Very fine light-blue sand ........ & 13 & 672 & 685 \\
\hline 30 & Light-blue rock $\ldots \ldots \ldots$ & 43 & 685 & 728 \\
\hline 31 & Bluish-gray sand ................. & 8 & 728 & 736 \\
\hline 32 & Light-gray sand with shells $\ldots$ & 14 & 736 & 750 \\
\hline 33 & Marl with small shells $\ldots \ldots$ & 6 & 750 & 756 \\
\hline 34 & Light bluish-gray sand and shells ... & 5 & 756 & 761 \\
\hline 35 & Fine sand and shells..... & 64 & 761 & 825 \\
\hline 36 & Very fine dark brownish-gray sand. . . & 49 & 825 & 874 \\
\hline 37 & $\begin{array}{l}\text { Hard grayish-blue sandy clay, with shells and } \\
\text { heavy indications of oil ... }\end{array}$ & 26 & 874 & $\mathbf{9 0 0}$ \\
\hline 38 & Dark rock 2 feet, shells 1 foot & 3 & 900 & 903 \\
\hline 39 & Dark grayish-blue sand with some clay $\ldots$ & 12 & 903 & 915 \\
\hline 40 & Lignite .... & 5 & 915 & 920 \\
\hline
\end{tabular}


Log of Higgius well No. , near southem margin of Spindletop pool-Continued.

\begin{tabular}{|c|c|c|c|c|}
\hline & Character of strata. & Thickness. ! & From- & To- \\
\hline 41 & Bluish-gray sand with shells & $\begin{array}{l}\text { Feet. } \\
\qquad 34\end{array}$ & $\begin{array}{l}\text { Feet. } \\
\quad 920\end{array}$ & $\begin{array}{l}\text { Feet. } \\
954\end{array}$ \\
\hline 42 & Bluish-gray rock. & 4 & 954 & 958 \\
\hline 43 & Very fine grayish-brown sand with shells & 24 & 958 & 982 \\
\hline 44 & Very fine sand with shells . . . . . . & 13 & 982 & 995 \\
\hline 45 & Dark gray rock, "cap rock". . & 5 & 995 & 1,000 \\
\hline 46 & Coarse dark gray sand with oil. & 6 & 1,000 & 1,006 \\
\hline
\end{tabular}

LIST OF PRODUCING WELLS IN SPINDLETOP POOL.

The following list gives the names of the wells in the Spindletop pool which have shown a yield of oil sufficient to be considered of commercial importance. It is as complete up to June 15,1902 , as it has been possible to make it by consulting numerous sources of information, although there are doubtless some omissions and inaccuracies. This is especially the case with the ownership of the wells, which is subject to frequent changes, and is sometimes difficult to determine. The size of the bottom or inner casing and the depth of the well have been given wherever ascertained. Not all of these wells are to be credited with actual commercial production, since many of them, after having been "brought in" and allowed to flow long enough to free themselves of any obstructions, have been closed up and never connected with a tank or pipe line. They have been potentially productive but actually dead. The reason for this has been the lack of facilities for storing or transporting the oil.

Producing wells in Spindletop pool.

\begin{tabular}{|c|c|c|c|c|}
\hline $\begin{array}{c}\text { No. } \\
\text { on } \\
\text { map. }\end{array}$ & Name of well. & Name of owner. & $\begin{array}{l}\text { Size of } \\
\text { casing. }\end{array}$ & $\begin{array}{l}\text { Depth of } \\
\text { well. }\end{array}$ \\
\hline & & & Inches. & Feet. \\
\hline 1 & McFadden No. 1 . & J. M. Guffey Petroleum Co. & 6 & 1,139 \\
\hline 2 & National No. 1 & National Oil and Pipe Line Co. & 6 & 1,018 \\
\hline 3 & Gladys No. 1 .. & J.M. Guffey Petroleum Co & 4 & 1,070 \\
\hline 4 & Higgins No. 1 . & Higgins Oil and Fuel Co... & 4 & 1,040 \\
\hline 5 & Gladys No. 2... & J.M. Guffey Petroleum Co & 6 & 1,092 \\
\hline 6 & Heywood No. 1 . & Heywood Oil Co $\ldots \ldots \ldots$ & 4 & 925 \\
\hline 7 & Gladys No. $3 \ldots$ & J.M. Guffey Petroleum Co & 6 & 769 \\
\hline 8 & Star and Crescent No. 1 . & Star and Crescent Oil Co & 6 & $93 \tilde{5}$ \\
\hline 9 & Gladys No. 4 .. & J.M. Guffey Petroleum Co ... & 6 & 765 \\
\hline 10 & Heywood No. 2 & Heywood Oil Co .. & 6 & 967 \\
\hline 11 & McFadden No. 3 & J. M. Guffey Petroleum Co & 6 & 1,028 \\
\hline 12 & McFadden No. 2 & $\ldots$. . do .... & 6 & 976 \\
\hline
\end{tabular}


Producing wells in Spindletop pool-Continued.

\begin{tabular}{|c|c|c|c|c|}
\hline $\begin{array}{c}\text { No. } \\
\text { on } \\
m g=0\end{array}$ & Name of well. & Name of owner. & $\begin{array}{l}\text { Size of } \\
\text { casing. }\end{array}$ & $\begin{array}{c}\text { Depth of } \\
\text { well. }\end{array}$ \\
\hline & & & Inches. & Feet. \\
\hline 13 & Heywood No. 3. & Heywood Oil Co ....... & 6 & 950 \\
\hline 14 & Hogg Swayne No. & Hogg Swayne Syndicate & 2 & 1,006 \\
\hline 15 & Higgins No. 2 & Higgins Oil and Fuel Co. & 6 & 1,006 \\
\hline 16 & Columbia No. 1 & Columbia Oil Co....... & 8 & 796 \\
\hline 17 & National No. 2 & National Oil and Pipe Line Co & 6 & 974 \\
\hline 18 & Spindle Top No. 1 & Spindle Top Oil Co & 4 & 940 \\
\hline 19 & Ground Floor No. 1 & Ground Floor Oil Co & 6 & 971 \\
\hline 20 & Glayds No. 5 & J. M. Guffey Petroleum Co & 8 & 830 \\
\hline 21 & Yellow Pine No. 1 & Yellow Pine Oil Co & 6 & 957 \\
\hline 22 & Cox Josey & Alamo City & 6 & $\cdots$ \\
\hline 23 & Manhattan No. 1 & Manhattan Oil Co & 4 & 937 \\
\hline 24 & Darragh & St. Marys Oil Co..... & 6 & 970 \\
\hline 25 & Cattlemen's & Cattlemen's Oil Co & 6 & 985 \\
\hline 26 & Alamo & Ala & 6 & 960 \\
\hline 27 & Bes & Ber & 6 & 1,017 \\
\hline 28 & Export No. 1 & Export Oil and Pipe Line Co & 6 & 1,060 \\
\hline 29 & El Beaumont . & El Beaumont Oil Co . . . . . . & 6 & 920 \\
\hline 30 & To. $3 \ldots$ & Pipe Line Co. & 6 & 965 \\
\hline 31 & Fountain .... & in Oil and Fuel Co. & 6 & 938 \\
\hline 32 & El Paso ..... & so Oil Co & 6 & 1,025 \\
\hline 33 & Spa & lechanics & 6 & $\ldots$ \\
\hline 34 & Palestine and Brut . & Palestine and Brut Oil Co. & 8 & 924 \\
\hline 35 & Mississippi and Texas.. & Mississippi and Texas Oil Co _. . & 6 & $\ldots$ \\
\hline 36 & Federal Crude (Grace) & $\begin{array}{l}\text { Federal Crude and Grace Oil } \\
\text { Companies. }\end{array}$ & 6 & 1,025 \\
\hline 37 & $\begin{array}{l}\text { Missouri, Kansas and } \\
\text { Texas. }\end{array}$ & $\begin{array}{l}\text { Missouri, Kansas and Texas } \\
\text { Oil Co. }\end{array}$ & 6 & 1,027 \\
\hline 38 & Gober No. $2 .$. & Gober Oil Co .... & 6 & 840 \\
\hline 39 & Dri & Oil Co. & 6 & 1,020 \\
\hline 40 & Fort & h Oil Co... & 6 & \\
\hline 41 & Gladys No. 6 . & J. M. Guffey Petroleum Co. & 6 & 1,028 \\
\hline 42 & $\begin{array}{l}\text { Beaumont Confederated } \\
\text { No. } 1 .\end{array}$ & Beaumont Confederated Oil Co. & 6 & 975 \\
\hline 43 & Buffalo & $\mathrm{Bu}$ & 6 & 960 \\
\hline 44 & Enterprise & Moore Skinner Com. Co $\ldots$ & 6 & \\
\hline 45 & Georgetown Waco & Georgetown and Waco Oil Co. & 6 & 950 \\
\hline 46 & Oteri No. 1 & Oteri Syndicate... & 6 & \\
\hline 47 & Geyser-Kallenbac & $\left\{\begin{array}{l}\text { Geyser Oil Development Co.. } \\
\text { Kallenbach Oil Co } \ldots \ldots \ldots\end{array}\right.$ & 6 & 930 \\
\hline 48 & & Eureka Oil Co........... & 6 & 920 \\
\hline 49 & Trenton Rock & Trenton Rock Oil Co. & 6 & 1,044 \\
\hline
\end{tabular}


Producing wells in Spindletop pool-Continued.

\begin{tabular}{|c|c|c|c|c|}
\hline $\begin{array}{c}\text { No. } \\
\text { on } \\
\text { msp. }\end{array}$ & Name of well. & Name of owner. & $\begin{array}{l}\text { Size of } \\
\text { casing. }\end{array}$ & $\begin{array}{l}\text { Depth of } \\
\text { well. }\end{array}$ \\
\hline & & & Inches. & Feet. \\
\hline 50 & Queen of Waco & Queen of Waco Oil Co. & 6 & \\
\hline 51 & Star and Crescent No. 2 & Star and Crescent Oil Co. & 6 & $\ldots$ \\
\hline 52 & $\begin{array}{l}\text { German-American No. } \\
\quad 2 .\end{array}$ & German-American Oil Co.. & 6 & 956 \\
\hline 53 & Paragon & Paragon Oil Co.. & 6 & 914 \\
\hline 54 & Cincinnati-Beaumont.. & $\begin{array}{l}\text { Cincinnati and Beaumont Oil } \\
\text { Co. }\end{array}$ & 6 & 925 \\
\hline 55 & King & King Oil Co. & 6 & 960 \\
\hline 56 & $\begin{array}{l}\text { Detroit, Beaumont and } \\
\text { Home. }\end{array}$ & $\begin{array}{l}\text { Detroit, Beaumont and Home } \\
\text { Oil Co. }\end{array}$ & 6 & 937 \\
\hline 57 & Alabama . & Alabama Oil and Pipe Co... & 6 & \\
\hline 58 & Hogg-Swayne No. 2... & Hogg-Swayne Syndicate . . . & 6 & \\
\hline 59 & Commonwealth ...... & Commonwealth Oil Co..... & 6 & \\
\hline 60 & $\begin{array}{l}\text { Twentieth Century } \\
\text { No. } 1 .\end{array}$ & Twentieth Century Oil Co & 6 & \\
\hline 61 & Manhattan No. 2 & Manhattan Oil C & 8 & 1,009 \\
\hline 62 & Hogg-Swayne No. 3 _ & Hogg-Swayne Syndicate _ _ & 6 & \\
\hline 63 & Geyser ...... & Geyser Oil Co & 6 & 1,023 \\
\hline 64 & Gladys of Beaumont. & Gladys Oil & 6 & 1,025 \\
\hline 65 & Saratoga & Saratoga Oil and Pipe Line Co. & 6 & \\
\hline 66 & $\begin{array}{l}\text { German - American } \\
\text { No. } 1 .\end{array}$ & German-American Oil Co.. & 8 & 920 \\
\hline 67 & Hogg-Swayne No. $4 \ldots$ & Hogg-Swayne Syndicate & 6 & 1,060 \\
\hline 68 & Houston-Beaumont .... & $\begin{array}{l}\text { Houston-Beaumont Oil and } \mathrm{Re}- \\
\text { fining Co. }\end{array}$ & 6 & 1,000 \\
\hline 69 & $\begin{array}{l}\text { American Oil and Re- } \\
\text { fining Co. }\end{array}$ & American Oil and Refining Co & 8 & \\
\hline 70 & $\begin{array}{c}\text { Greater New York } \\
\text { Home. }\end{array}$ & Greater New York Home Oil Co_ & 4 & 986 \\
\hline 71 & Cartwright........ & $\begin{array}{l}\text { Cartwright Oil and Develop- } \\
\text { ment Co. }\end{array}$ & 6 & 941 \\
\hline 72 & Oteri No. 2 & Oteri Syndicate & 6 & \\
\hline 73 & McFadden No. 8. . . . . & J. M. Guffey Petroleum Co & 6 & 860 \\
\hline 74 & Anglo-American No. 2. & Anglo-American Oil Co. . . & 6 & . . . . . \\
\hline 75 & $\begin{array}{l}\text { Twentieth Century } \\
\text { No. } 2 .\end{array}$ & Twentieth Century Oil Co. & 6 & 1,051 \\
\hline 76 & Finlay $\ldots \ldots \ldots$ & Apex & 8 & 976 \\
\hline 77 & San Jacinto No. 2 & San Jacinto Oil Co & 6 & 1,059 \\
\hline 78 & Trans-Mississippi . . & Trans-Mississippi Oil Co. & 4 & \\
\hline 79 & Spindle Top No. 2 & Spindle Top Oil Co & 6 & \\
\hline 80 & Stribling Cox No. 1... & Stribling \& Cox . . & 6 & 1,015 \\
\hline 81 & Hogg-Swayne No. 5 . & Hogg-Swayne Syndicate _ & 6 & 1,003 \\
\hline 82 & Plunger. & Texas Oil and Pipe Line Co. & 8 & 1,036 \\
\hline 83 & Ira 0. Wise - & Ira O. Wise Beaumont Oil Co.. & 6 & \\
\hline
\end{tabular}


Producing wells in Spindletop pool-Continued.

\begin{tabular}{|c|c|c|c|c|}
\hline $\begin{array}{c}\text { No. } \\
\text { on } \\
\text { map. }\end{array}$ & Name of well. & Name of owner. & $\begin{array}{l}\text { Size of } \\
\text { casing. }\end{array}$ & $\begin{array}{l}\text { Depth of } \\
\text { well. }\end{array}$ \\
\hline & & & Inches. & Feet. \\
\hline 84 & Kiser & Hayne \& Bro & 6 & \\
\hline 85 & Keith Ward No. 1. & Keith Ward Oil Co... & 6 & 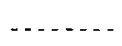 \\
\hline 86 & Citizens' Consolidated & Citizens' Consolidated Oil Co & 6 & \\
\hline 87 & $\begin{array}{l}\text { Beaumont Confeder- } \\
\text { ated No. } 2 .\end{array}$ & Beaumont Confederated Oil Co & 6 & 975 \\
\hline 88 & Tri-City No. 1 & Tri-City Oil Co. & 6 & \\
\hline 89 & $\begin{array}{l}\text { Cincinnati-Beanmon t } \\
\text { No. } 2 .\end{array}$ & Cincinnati-Beaumont Oil & 6 & 986 \\
\hline 90 & Old Reliable. . & Cronin Land and Oil Co & 6 & \\
\hline 91 & Two Republics & Two Republics Oil Co .... & 6 & \\
\hline 92 & $\begin{array}{l}\text { Beaumont Confeder- } \\
\text { ated No. } 3 .\end{array}$ & Beaumont Confederated Oil Co. & 6 & \\
\hline 93 & Gladys No. $7 \ldots$ & J. M. Guffey Petroleum Co & 6 & \\
\hline 94 & Lone & Star and Crescent Oil Co & 6 & \\
\hline 95 & Guarantee & Guarantee Oil Co...... & 6 & \\
\hline 96 & Arkadelphia & Arkadelphia Oil Co & 8 & 1,025 \\
\hline 97 & ayne No. & Hogg-Swayne Syndicate & 6 & \\
\hline 98 & Mercer Co. & Mercer County Oil Co. & 6 & 996 \\
\hline 99 & Yellow Pine No. 2 & Yellow Pine Oil Co .... & 6 & \\
\hline 100 & Caldwell No. 1 & Caldwell Oil Co ........ & 6 & - . . n \\
\hline 101 & Anglo-American No. 1. & Anglo-American Oil Co.. & 6 & 1,053 \\
\hline 102 & Texas Standard No. 1. & Texas Standard Oil Co... & 6 & 1,078 \\
\hline 103 & City & Mound City Oil Co...... & 6 & 977 \\
\hline 104 & Brooks & R. E. Brooks $\ldots \ldots$ & 6 & 1,090 \\
\hline 105 & Cronin & Cronin Land and Oil Co. & 6 & 940 \\
\hline 106 & $\begin{array}{l}\text { Federal Crude, Grace } \\
\text { No. } 2 .\end{array}$ & Federal Crude Oil Co ..... & 8 & 1,025 \\
\hline 107 & $\begin{array}{l}\text { Beaumont and Damon } \\
\text { Mound. }\end{array}$ & $\begin{array}{l}\text { Beaumont and Damon Mound } \\
\text { Oil Co. }\end{array}$ & 6 & 977 \\
\hline 108 & Madeline Consolidated_ & Madeline Consolidated Oil Co. & 6 & 990 \\
\hline 109 & Knickerbocker .... & Josey Investment Co..... & 6 & - - - \\
\hline 110 & San Jacinto No. 1 . & San Jacinto Oil Co. ... & 6 & 934 \\
\hline 111 & Globe & Globe Oil Co & 8 & 1,040 \\
\hline 112 & Granite Mountain .. & Granite Mountain Oil Co. & 6 & \\
\hline 113 & Fort Worth No. $2 \ldots$ & Fort Worth Oil Co & 6 & \\
\hline 114 & Keith Ward No. 2 & Keith Ward Oil Co.... & 6 & \\
\hline 115 & Hogg-Swayne No. 6 & Hogg-Swayne Syndicate & 6 & -1 \\
\hline 116 & Calloway Oil ........ & Calloway Oil Co...... & 6 & $\ldots$ \\
\hline 117 & Anglo-American No. 3. & Anglo-American Oil Co & 6 & 1,072 \\
\hline 118 & Diamond Crude & Diamond Crude Oil Co & 6 & 1,028 \\
\hline 119 & R. A. Josey - & R.A. Aosey & 6 & - \\
\hline 120 & H. M. Mitchell _ & Mitchell Oil Co. & 6 & \\
\hline
\end{tabular}


Producing wells in Spindletop pool-Continued.

\begin{tabular}{|c|c|c|c|c|}
\hline $\begin{array}{l}\text { No. } \\
\text { on } \\
\text { map. }\end{array}$ & Name of well. & Name of owner. & $\begin{array}{l}\text { Size of } \\
\text { casing. }\end{array}$ & $\begin{array}{l}\text { Depth of } \\
\text { well. }\end{array}$ \\
\hline & & & Inches. & Feet. \\
\hline 121 & Hansen & New York Oil Co. & 6 & \\
\hline 122 & McFadden No. 7 & J. M. Guffey Petroleum Co & 6 & 1,030 \\
\hline 123 & Equitable ... & Equitable Oil Co ...... & 6 & \\
\hline 124 & Simms Bartlett. . & Simms Bartlett \& Harrison & 6 & \\
\hline 125 & McFadden No. 9 & J. M. Guffey Petwoleum Co & 6 & 1,042 \\
\hline 126 & Bunns Bluff. & Bunns Bluff Oil Co .. & 6 & \\
\hline 127 & Independence & Independence Oil Co.. & 6 & \\
\hline 128 & Godcheux . & & 6 & \\
\hline 129 & Beaumont. & Beaumont Oil Co ... & 6 & \\
\hline 130 & Seaboard No. 2 & Seaboard Oil Co $\ldots \ldots \ldots$ & 6 & \\
\hline 131 & Texas Geyser .... & Texas Geyser Oil Co. & 6 & \\
\hline 132 & Lumberman . . & Lumberman's Oil Co . & 6 & \\
\hline 133 & $\begin{array}{l}\text { Texas Oil and Pipe } \\
\text { Line No. } 2 .\end{array}$ & Texas Oil and Pipe Line Co & 8 & 1,098 \\
\hline 134 & Peoria Crude. & Peoria Crude Oil Co & 6 & 948 \\
\hline 135 & Becky Sharp & Becky Sharp Oil Co ... & 6 & \\
\hline 136 & Jones Development & C. E. Jones and others. . & 6 & 1,034 \\
\hline 137 & $\begin{array}{l}\text { Beaumont Petroleum } \\
\text { and Gas. }\end{array}$ & $\begin{array}{l}\text { Beaumont Petroleum and Gas } \\
\text { Ca. }\end{array}$ & 6 & 1,075 \\
\hline 138 & Silver Dime No. 1 & Silver Dime Oil Co & 6 & \\
\hline 139 & Silver Dime No. 2 & - & 6 & \\
\hline 140 & Chicago-Texas No. 1 . & Chicago-Texas Syndicate - & 6 & 950 \\
\hline 141 & Hogg-Swayne No. 7. & Hogg-Swayne Syndicate. & 6 & \\
\hline 142 & Chicago-Texas No. 2... & Chicago-Texas Syndicate & 9 & 1,055 \\
\hline 143 & The Mercantile . & $\begin{array}{l}\text { The Mercantile Oil and Refin- } \\
\text { ing Co. }\end{array}$ & 6 & 914 \\
\hline 144 & $\begin{array}{l}\text { German - American } \\
\text { No. } 3 .\end{array}$ & German-American Oil Co ... & 6 & 932 \\
\hline 145 & Queen of Beaumont & Queen of Beaumont Oil Co & 6 & $\cdots$ \\
\hline 146 & Paulhamus . - & I. A. Paulhamus & 6 & 1,018 \\
\hline 147 & Beaumont Associated. & $\begin{array}{l}\text { Beaumont Associated Oil Wells } \\
\text { Co. }\end{array}$ & 6 & \\
\hline 148 & R. L. $\operatorname{Cox}$ & R. L. $\operatorname{Cox} \mathrm{Co}$ & 6 & 1,050 \\
\hline 149 & Alabama-Texas - & $\begin{array}{l}\text { Alabama-Texas Oil and Trans- } \\
\text { portation Co. }\end{array}$ & 6 & \\
\hline 150 & $\begin{array}{l}\text { Beaumont and Pacific } \\
\text { Slope. }\end{array}$ & $\begin{array}{l}\text { Beaumont and Pacific Slope Oil } \\
\text { Co. }\end{array}$ & 6 & \\
\hline 151 & Illinois Oil Co. No. 1 _. & חlinois Oil Co. . . . . . . . . & 6 & \\
\hline 152 & Rex Petroleum & Rex Petroleum Oil Co . & 6 & \\
\hline 153 & Gladys No. 8 & J. M. Guffey Petrolenm Co.... & 6 & \\
\hline 154 & $\begin{array}{l}\text { Birmingham - B e a u - } \\
\text { mont. }\end{array}$ & $\begin{array}{l}\text { Birmingham - Beaumont Oil } \\
\text { and Transportation. }\end{array}$ & 6 & \\
\hline
\end{tabular}

Bull. 212-03-6 
OIL FIELDS OF TEXAS-LOUISIANA COASTAL PLAIN. [BULL.212.

Producing wells in Spindletop pool-Continued.

\begin{tabular}{|c|c|c|c|c|}
\hline $\begin{array}{c}\text { No. } \\
\text { on } \\
\text { map. }\end{array}$ & f well. & Name of owner. & $\begin{array}{l}\text { Size of } \\
\text { casing. }\end{array}$ & $\begin{array}{c}\text { Depth of } \\
\text { well. }\end{array}$ \\
\hline & & & Inches. & Fee \\
\hline 155 & Adams . . . . & Adams Oil Co. & 6 & \\
\hline 156 & Chicago-Texas No. 1 . & & 6 & \\
\hline 157 & Chicago-Texas Export_- & & 6 & \\
\hline 158 & $\begin{array}{l}\text { Chicago-Texas Syndi- } \\
\text { cate. }\end{array}$ & & 6 & \\
\hline 159 & Mercer County No. 2 . & Mercer County Oil Co. & 6 & \\
\hline 160 & Forward Reduction & Forward Reduction Co & 6 & $\ldots \ldots$ \\
\hline 161 & Robertson & J. Robertson & 6 & 1,056 \\
\hline 162 & Oklahoma and $\mathrm{Te}$ & & 6 & 1,085 \\
\hline 163 & Heywood No. 4. & Heywood Oil Co.. & & \\
\hline 164 & Higgin & Higgins Oil and Fue & & \\
\hline 165 & Hogg-Swayne No. 8 & Hogg-Swayne Syndicate. . & & \\
\hline 166 & Ground Floor No. 2... & Ground Floor Oil Co . . . . . & & \\
\hline 167 & $\begin{array}{l}\text { i, Kansas and } \\
\text { No. } 2 .\end{array}$ & $\begin{array}{l}\text { Missouri, Kansas and Texas } \\
\text { Oil Co. }\end{array}$ & & \\
\hline 168 & $\begin{array}{l}\text { Georgetown-Waco No. } \\
\quad 2 .\end{array}$ & Georgetown-Waco Oil Co & & \\
\hline 169 & $\begin{array}{l}\text { Beaumont and Damon } \\
\text { Mound No. } 2 \text {. }\end{array}$ & $\begin{array}{l}\text { Beaumont and Damon Mound } \\
\text { Oil Co. }\end{array}$ & & \\
\hline 170 & Reduction No. & Forward Reduction Co & & \\
\hline 171 & Denver-Beaumont No. 1 & ont Oil Co & 6 & 1,088 \\
\hline 172 & Lucky Dime & Lucky Dime Oil Co........ & & \\
\hline 173 & $\mathrm{Em}$ & $\begin{array}{l}\text { Empire State Coal, Iron and } \\
\text { Oil Co. }\end{array}$ & & \\
\hline 174 & Hatresoun- & Gla & & \\
\hline 175 & $\mathrm{Hu}$ & y Oil and Refining Co & & \\
\hline 176 & Tri-City No. 2 & Tri-City Oil Co..... & & \\
\hline 177 & Guffey & J. M. Guffey Petroleum Co & & \\
\hline 178 & Do & $\ldots$ & & \\
\hline 179 & Spind & Spir & & \\
\hline 180 & Bor & Oil Co & & \\
\hline 181 & Geyser of Galveston. . & Geyser Oil Co. of Galveston & & \\
\hline 182 & Lones & Lone & & \\
\hline 183 & Lone & Lone & & \\
\hline 184 & Lone $A$ & $\ldots$ do & & \\
\hline 185 & Lone A & ..... do & & \\
\hline 186 & Ma & Maskemp Oil Co & & \\
\hline 187 & Sunset No. 2 & Sunset Oil Co & & \\
\hline 188 & St. Louis-Spindle Top - . & St. Louis-Spindle Top Oil Co & & \\
\hline 189 & Drummond & Drummond Oil Co & & \\
\hline 190 & Texas Live Oak & Texas Live Oak Oil C & & \\
\hline
\end{tabular}


Producing wells in Spindletop pool-Continued.

\begin{tabular}{|c|c|c|c|c|}
\hline $\begin{array}{c}\text { No. } \\
\text { on } \\
\text { map. }\end{array}$ & Name of well. & Name of owner. & $\begin{array}{l}\text { Size of } \\
\text { casing. }\end{array}$ & $\begin{array}{l}\text { Depth of } \\
\text { well. }\end{array}$ \\
\hline & & & $s$. & Feet. \\
\hline 191 & Zenith & Zenith Oil Co & & \\
\hline 192 & United States No. 1. & United States Oil and Fuel Co & & \\
\hline 193 & United States No. 2 . & do & & \\
\hline 194 & United States No. 3 & . do ......... & & \\
\hline 195 & United States No. 4 & $\ldots$.... do ... & & \\
\hline 196 & Babbit Syndicate & Babbit Syndicate Oil Co & & \\
\hline 197 & British American & British American Oil $\mathrm{Co}_{-}$ & & \\
\hline 198 & Bayou City No. 2 & Bayou City Oil Co . . . . . . & & \\
\hline 199 & Mound City & Pittsburg Mound City . & & \\
\hline 200 & Magnolia & Magnolia Oil Co. & & \\
\hline 201 & Sam Houston ..... & Sam Houston Oil Co ...... & & \\
\hline 202 & $\begin{array}{l}\text { Chicago-Texas Syndi- } \\
\text { cate. }\end{array}$ & Chicago-Texas Syndicate & & \\
\hline 203 & Higgins No. 4 & Higgins Oil and Fuel $\mathrm{Co}_{-}$ & & \\
\hline 204 & Kansas City. - & $\begin{array}{l}\text { Kansas City Oil and Refining } \\
\text { Co. }\end{array}$ & & \\
\hline 205 & Iowa-Nebr & $\begin{array}{l}\text { Iowa-Nebraska-Beaumont Oil } \\
\text { Co. }\end{array}$ & & \\
\hline 206 & Imperial & Imperial Oil Co $\ldots . . . . .$. & & \\
\hline 207 & $\begin{array}{l}\text { Beaumont and Spindle- } \\
\text { top. }\end{array}$ & $\begin{array}{l}\text { Beaumont and Spindletop Oil } \\
\text { Co. }\end{array}$ & & \\
\hline 208 & Black Hawk ... & Hawk Oil Co ......... & & \\
\hline 209 & Burlington .. & Burlington Oil Co & & 942 \\
\hline 210 & Buckeye ..... & Buckeye Oil Co....... & & \\
\hline 211 & Big & Big & & \\
\hline 212 & Burt-Missouri & Burt-Missouri Oil Co .. & & \\
\hline 213 & Cascade ...... & Cascade Oil Co & & \\
\hline 214 & Che & Che & & \\
\hline 215 & Blue Grass & Blue Grass Oil Co & & \\
\hline 216 & Drummers ..... & Drummers Oil Co $\ldots . . .$. & & \\
\hline 217 & Continental & Continental Oil Co. & & \\
\hline 218 & Cedar Rapids . . . & Cedar Rapids Mission Oil Co. & & \\
\hline 219 & Call \& Polk & D. Call and I. D. Polk & & \\
\hline 220 & R. L. Cox No. $1 \ldots$ & R. L. $\operatorname{Cox}$ & & \\
\hline 221 & $\begin{array}{l}\text { Lake Superior and } \\
\text { Beaumont. }\end{array}$ & $\begin{array}{l}\text { Lake Superior and Beaumont } \\
\text { Oil Co. }\end{array}$ & & \\
\hline 222 & R. L. Cox No. 2 .. & R. L. Cox & & \\
\hline 223 & New England ... & $\begin{array}{l}\text { New England and Beaumont } \\
\text { Oil Co. }\end{array}$ & & \\
\hline 224 & North American Crude & North American Crude Oil Co. & & \\
\hline 225 & Crescent & Crescent Oil Co..... & & \\
\hline 226 & Omaha and Texas & Omaha and Texas Oil Co & & \\
\hline
\end{tabular}


OIL HIELDS OF TEXAS-LOUISIANA COASTAL PLAIN. [BULl.212.

Producing wells in Spindletop pool--Continued.

\begin{tabular}{|c|c|c|c|c|}
\hline $\begin{array}{c}\text { No. } \\
\text { on } \\
\text { map. }\end{array}$ & Name of well. & Name of owner. & $\begin{array}{l}\text { Size of } \\
\text { casing. }\end{array}$ & $\begin{array}{c}\text { Depth of } \\
\text { well. }\end{array}$ \\
\hline & & & & Feet. \\
\hline 227 & Cotton Oil. & Cotton Oil and Pipe Line Co. & & \\
\hline 228 & Sutchliffe & Sutchliffe Oil Co_... & & \\
\hline 229 & Minnesota No. 1 & Minnesota Oil Co & & \\
\hline 230 & Minnesota No. 2 . & -. do - & & \\
\hline 231 & Carroll \& Co & F. L. Carroll _. . . & & \\
\hline 232 & & & & \\
\hline 233 & Consolidated & $\begin{array}{l}\text { Consolidated Oil and Pipe Line } \\
\text { Co. }\end{array}$ & & \\
\hline 234 & Consumers & Consumers' Oil and Pipe Line Co & & \\
\hline 235 & Detroit-Saginaw & Detroit-Saginaw Valley Oil Co & & \\
\hline 236 & Empire No. 2... & $\begin{array}{l}\text { Empire State Oil, Iron and } \\
\text { Coal Co. }\end{array}$ & & \\
\hline 237 & Eastern Texas & $\begin{array}{l}\text { Eastern Texas Oil and Develop- } \\
\text { ment Co. }\end{array}$ & & \\
\hline 238 & Equitable No. 2 & Equitable Land and Oil Co & & \\
\hline 239 & El Beaumont No. 2 & El Beaumont Oil Co...... & & \\
\hline 240 & Flora Oil Co & Flora Oil Co .... & & \\
\hline 241 & Fairfield & Clarke Fairfield & & \\
\hline 242 & Fairchild . & L. H. Fairchild. . & & \\
\hline 243 & Galveston and Burt & Galveston and Burt Oil Co & & \\
\hline 244 & Good Luck. & Good Luck Oil Co . . . . . & & \\
\hline 245 & Greater New York No.2 & Greater New York Oil Co. & & \\
\hline 246 & Greater New York No.3 & $\ldots$ do $\ldots \ldots$ & & \\
\hline 247 & Home & Home Oil Co ....... & & \\
\hline 248 & Interstate $\ldots$ & Interstate Oil Co $\ldots . . .$. & & \\
\hline 249 & $\mathrm{Lib}$ & (n) & & \\
\hline 250 & Louisiana Purchase & Louisiana Purchase Oil Co. & & \\
\hline 251 & Midland & Midland Oil Co $\ldots . . . . . . .$. & & \\
\hline 252 & Minnesota Oil No. 3 & Minnesota Oil Co ......... & & \\
\hline 253 & Michigan-Burt _ & $\begin{array}{l}\text { Michigan-Burt Oil and Refining } \\
\text { Co. }\end{array}$ & & \\
\hline 254 & Mississippi-Texas . & Mississippi-Texas Oil Co . & & \\
\hline 255 & Nickel Plate No. 1. & Nickel Plate Oil Co. & & \\
\hline 256 & Nickel Plate No. 2 & . do $\ldots$ & & \\
\hline 257 & People's. ... & People's Oil Co $\ldots . . . . .$. & & \\
\hline 258 & Pittsburg & Pittsburg-Texas Oil Co & & \\
\hline 259 & Rock River & Rock River Oil and Pipe Line Co & & \\
\hline 260 & Reed & N. Cabell Reed & & \\
\hline 261 & Sun Oil & Sun Oil Refining Co ... & & \\
\hline 262 & Sabine & Sabine Oil and Pipe Line Co & & \\
\hline 263 & Sacramento & $\begin{array}{l}\text { Sacramento Oil and Pipe Line } \\
\text { Co. }\end{array}$ & & \\
\hline
\end{tabular}


Producing wells in Spindletop pool-Continued.

\begin{tabular}{|c|c|c|c|c|}
\hline $\begin{array}{l}\text { No. } \\
\text { on } \\
\text { map. }\end{array}$ & Name of well. & Name of owner. & $\begin{array}{l}\text { Size of } \\
\text { casing. }\end{array}$ & $\begin{array}{l}\text { Depth of } \\
\text { well. }\end{array}$ \\
\hline & & & Inches. & Feet. \\
\hline 264 & Springfield _ & Springfield-Beanmont Oil Co . & & \\
\hline 265 & Sterling - & Sterling Oil Co & & \\
\hline 266 & Spindletop No. 3 & Spindletop Oil Co.... & & \\
\hline 267 & Sabine ......... & Sabine Oil and Marketing Co & & \\
\hline 268 & St. Marys ... & St. Marys Oil Co $\ldots . .$. & & \\
\hline 269 & Sarpy - & $\begin{array}{l}\text { Sarpy Oil and Transportation } \\
\text { Co. }\end{array}$ & & \\
\hline 270 & St. Louis-Spindletop _. & St. Louis-Spindletop Oil Co & & \\
\hline 271 & Texas Fuel Oil Co & Texas Fuel Oil Co . .... & & \\
\hline 272 & Thompson Hill No. 1 .. & Thompson Hill Development Co & & \\
\hline 273 & Thompson Hill No. 2 & do & & \\
\hline 274 & Texas-American & Texas-American Oil Co & & \\
\hline 275 & The Fifteen & The Fifteen Oil Co........ & & \\
\hline 276 & Union $\ldots \ldots \ldots$ & Union Oil Co & & \\
\hline 277 & Union Oil and Refining & Union Oil and Refining $\mathrm{Co}_{-}$ & & \\
\hline 278 & Waco-Burt $\ldots$ & Waco-Beaumont Oil Co . . . & & \\
\hline 279 & White King . . . . & White King Oil Co ...... & & $\ldots$ \\
\hline 280 & Ward & W. K. Ward & & \\
\hline
\end{tabular}

\section{REGION SURROUNDING SPINDLETOP POOL.}

In the region surrounding the Spindletop pool a large amount of prospecting has been done, but up to the present time no productive territory has been developed. This region is a very level plain, for the most part treeless prairie, but with some considerable timbered areas. The monotony of the surface is relieved only by the broad flood plain of the Neches River, which is but slightly above tide level and generally occupied by cypress and other swamps.

The wells, whose locations are shown on the accompanying map, fig. 3, vary in depth from 1,200 to 2,400 feet. Although none of them are productive, most have shown some signs of oil, probably derived from beds corresponding to those which yield small quantities of oil over the main oil rock in the Spindletop pool. They furnish considerable information regarding the character of the beds underlying the Coastal Plain, and a number of the logs are here given in order that they may be on record.

From what has already been said concerning the normal thickness of the Gulf Coastal Plain formations and the structure of the Spindletop pool, it is evident that a well in this region less than 3,000 feet in depth does not reach the oil-bearing horizon anywhere except upon the Spindletop dome. It can not be said, therefore, that the possi- 
bilities of finding oil in this region have been exhausted by the relatively shallow wells thus far drilled. On the other hand, it can not be said that the probabilities of finding oil in paying quantities at greater depth are sufficient to warrant the great expense of prospecting. It might, however, be expedient to put down a cooperative test well, at some carefully selected locality, sufficiently deep to exhaust

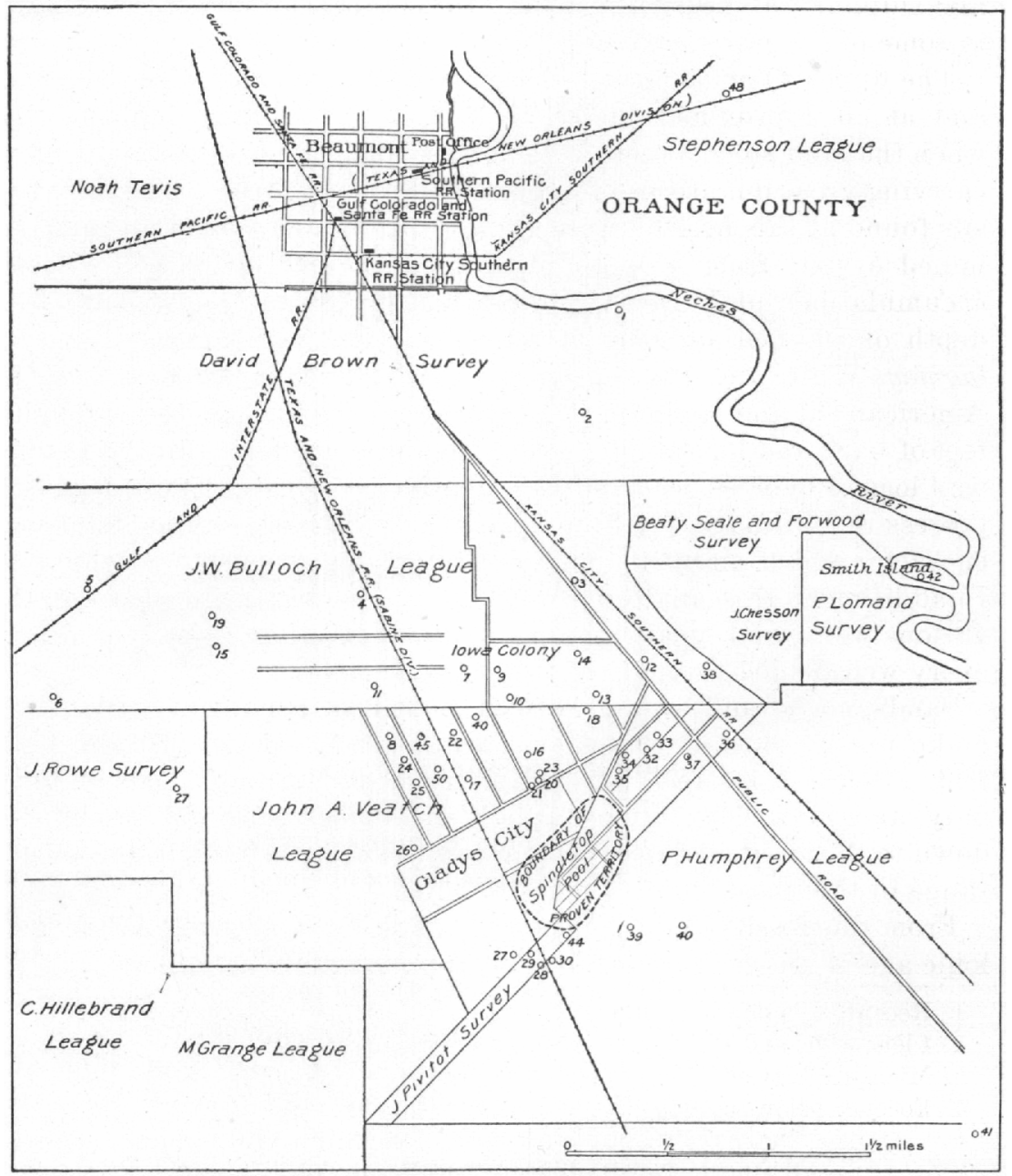

FIG. 3.-Map of region surrounding the Spindletop oil pool.

the possibilities. One such well put down to a depth of 3,000 or 3,500 feet would be of much more value than any number of wells half those depths.

The well records available in this region show the underlying formations to be largely heavy beds of blue clay and blue and gray sands, the latter being generally denominated quicksands by the drillers. 
Occasional thin beds of sandstone, with infrequent heavier beds and thin layers of limestone interstratified with sands and clays, also occur. In several of the wells many small fossils of Miocene age appear, usually associated with a bed of grayish-blue sand. A number of the sand beds are water bearing, and might form a fairly good source of water supply for the Beaumont district, if properly exploited. Salt and sulphur water also accompany these sands at, varions levels, and in some of the wells have developed considerable flows.

The upper 40 or 50 feet of these beds contain much recayed wood, and at an approximate depth of 45 feet the drillings indicate that when the land stood at that level it was subject to overflow by streams carrying great quantities of cypress and other timber. The only fossils found at this horizon were Rangia cuneata Gray and an undetermined oyster, from a depth of 45 feet, in the Harby well. These accumulations of buried vegetable matter continue downward to a depth of 800 feet in some of the wells. In the Island well Natica tuomeyi Whit. and Crassatella sp. were found at 800 feet. In the American Oil and Refining Company's well the drill passed through 8 feet of bark and $\operatorname{logs}$ at 892 feet and again at 994 feet. In the Decker well logs of cypress occurred at a depth of 800 feet. These logs still possess the ordinary woody texture, while the bark retains its fibrous character and often by its toughness interferes seriously with the drill. In addition to this unaltered wood, more or less lignite occurs in the various wells, and small seeps or deposits of oil are found in nearly every well drilled throughout this area.

Sands, clays, and even fair-sized bodies of sandstone and gravel make up the most of the strata encountered between 900 and 1,500 feet. Below 1,500 feet the drilling is mostly through beds of blue, gray, and pink clays interstratified with limestones and sandstones down to the greatest depth yet reached. The limestones in these beds range in thickness from 2 inches to 2 feet.

From the fossils found in the various wells in this region the geologic age of the beds appears to be approximately as follows

1. Recent; to a depth of 45 feet.

2. Pleistocene and Pliocene; between 45 feet and 800 feet.

3. Miocene; between 800 feet and 2,200 feet.

4. Eocene; below 2,200 feet.

WELL RECORDS.

The following well logs have been furnished, in all cases, by the owners of the wells or by the contractors with the owner's permission:

Beginning at the northern end of the field, two wells have been drilled on the D. Easley survey near Pine Island Bayou, about 9 miles north of Beaumont. These are known as the Sanger and Walker wells. Both are dry and have been abandoned. In drilling the Sanger 
well considerable trouble was experienced with water, especially in the first 600 feet. The following log is furnished by the contractors:

Log of Sanger well on D. Easley survey.

[Elevation, 25 feet.]

\begin{tabular}{|c|c|c|c|c|}
\hline No. & Character of strata. & Thickness. & From-- & To- \\
\hline 1 & Clay & $\begin{array}{l}\text { Feet. } \\
6\end{array}$ & $\begin{array}{l}\text { Feet. } \\
\quad 0\end{array}$ & $\begin{array}{l}\text { Feet. } \\
6\end{array}$ \\
\hline 2 & Coarse water sand. . & 150 & 6 & 156 \\
\hline 3 & Blue clay ............... & 6 & 156 & 162 \\
\hline 4 & $\begin{array}{l}\text { Alernate layers of clay and coarse white } \\
\text { sand, clay blue }\end{array}$ & 438 & 162 & 600 \\
\hline 5 & Shell rock . . & $\frac{1}{2}$ & 600 & $600 \frac{1}{2}$ \\
\hline 6 & Sand $\ldots \ldots \ldots \ldots$ & $40 \frac{1}{2}$ & $600 \frac{1}{2}$ & 641 \\
\hline 7 & Blue clay and sand, more clay than sand & 260 & 641 & 901 \\
\hline 8 & Shell rock . & 1 & 901 & 902 \\
\hline 9 & Sand....... & 30 & 902 & 932 \\
\hline 10 & Blue and red clay -- & 60 & 932 & 992 \\
\hline 11 & Sand and clay & 239 & 992 & 1,231 \\
\hline 12 & Shells_ & 1 & 1,231 & 1,232 \\
\hline 13 & Sand and clay . . . . & 27 & 1,232 & 1,259 \\
\hline 14 & Sand.... & 30 & 1,259 & 1,289 \\
\hline 15 & Clay ... & 20 & 1,289 & 1,309 \\
\hline 16 & Sand and shells . & 25 & 1,309 & 1,334 \\
\hline 17 & Clay ............ & 85 & 1,334 & 1,419 \\
\hline
\end{tabular}

Five miles west of Beaumont the American Oil Company's well shows a section consisting almost exclusively of clays and sands.

Log of American Oil Company's well in sec. 101, Texas and New Orleans Railway land.

[Elevation, 50 feet.]

\begin{tabular}{|c|c|c|c|c|}
\hline No. & Character of strata. & Thickness. & From- & To- \\
\hline & & Feet. & Feet. & Feet. \\
\hline 1 & Sand ... & 3 & 0 & 3 \\
\hline 2 & Yellow clay & 5 & 3 & 8 \\
\hline $\mathbf{3}$ & Quicksand & 10 & 8 & 18 \\
\hline 4 & Yellow clay _. . & 11 & 18 & 29 \\
\hline $\mathbf{5}$ & Fine sand and shells. & 3 & 29 & 32 \\
\hline 6 & Blue clay .... & 16 & 32 & 48 \\
\hline 7 & Sand ..... & 18 & 48 & 66 \\
\hline 8 & Blue clay & 12 & 66 & 78 \\
\hline $\mathbf{9}$ & Sand $\ldots$ & 10 & 78 & 88 \\
\hline 10 & Blue clay - . . . & 32 & 88 & 120 \\
\hline
\end{tabular}


Log of American Oil Company's well in sec. 101, etc.-Continued.

\begin{tabular}{|c|c|c|c|c|}
\hline No. & Character of strata. & Thickness. & From- & To- \\
\hline 11 & Fine sand and shells & $\begin{array}{l}\text { Feet. } \\
6\end{array}$ & $\begin{array}{l}\text { Feet. } \\
\quad 120\end{array}$ & $\begin{array}{l}\text { Feet. } \\
\quad 126\end{array}$ \\
\hline 12 & Blue clay .. & 20 & 126 & 146 \\
\hline 13 & Sand ..... & 28 & 146 & 174 \\
\hline 14 & Blue clay .. & 35 & 174 & 209 \\
\hline 15 & Sand ....... & 21 & 209 & 230 \\
\hline 16 & Blue clay . . . . . . . . . . . & 11 & 230 & 241 \\
\hline 17 & Blue clay & 23 & 241 & 264 \\
\hline 18 & Sand . & 8 & 264 & 272 \\
\hline 19 & Blue clay .... & 22 & 272 & 294 \\
\hline 20 & Sand $\ldots$ & 26 & 294 & 320 \\
\hline 21 & Blue clay & 19 & 320 & 339 \\
\hline 22 & Sand ........ & 64 & 339 & 403 \\
\hline 23 & Blue clay - . - & 37 & 403 & 440 \\
\hline 24 & Sand & 13 & 440 & 453 \\
\hline 25 & Blue clay & 31 & 453 & 484 \\
\hline 26 & Sand . & 6 & 484 & 490 \\
\hline 27 & Blue clay & 46 & 490 & 536 \\
\hline 28 & Sand ......... & 24 & 536 & 560 \\
\hline 29 & Blue clay .............. & 17 & 560 & 577 \\
\hline 30 & Sand with hard streaks & 13 & 577 & 590 \\
\hline 31 & Red clay $\ldots \ldots$ & 15 & 590 & 605 \\
\hline 32 & Soft sandstone & 2 & 605 & 607 \\
\hline $\mathbf{3 3}$ & Sand . ..... & 30 & 607 & 637 \\
\hline 34 & Sand with hard streaks & 3 & 637 & 640 \\
\hline 35 & Blue clay ... & 15 & 640 & 655 \\
\hline 36 & Sand ..... & 20 & 655 & 675 \\
\hline 37 & Blue clay..... & 17 & 675 & 692 \\
\hline 38 & $\ldots$.... do $\ldots . .$. & 8 & 692 & 700 \\
\hline 39 & Sand . . . . . & 65 & 700 & 765 \\
\hline 40 & $\begin{array}{l}\text { Fine quartz gravel from pea to marble size, } \\
\text { smooth, and varions colors }\end{array}$ & 10 & 765 & 775 \\
\hline 41 & Sand ............ & 65 & 775 & 840 \\
\hline 42 & Blue clay ... & 13 & 840 & 853 \\
\hline 43 & Sand ....... & 11 & 853 & 864 \\
\hline .44 & Red clay .... & 6 & 864 & 870 \\
\hline 45 & Sand $\ldots \ldots$ & 22 & 870 & 892 \\
\hline 46 & Bark and logs . . . . . . & 8 & 892 & 900 \\
\hline 47 & Blue clay ....... & 16 & 900 & 916 \\
\hline 48 & Sand and shells... & 10 & 916 & 926 \\
\hline 49 & Blue clay ... & 8 & 926 & 934 \\
\hline 50 & Sand $\ldots \ldots$ & 56 & 934 & 990 \\
\hline
\end{tabular}


OIL FIEI,DS OF TEXAS-LIOUISIANA COASTAL PLAIN. [BULL.212.

Log of American Oil Company's well in sec. 101, etc.-Continued.

\begin{tabular}{|c|c|c|c|c|}
\hline No. & Character of strata. & Thickness. & From- & To- \\
\hline 51 & Hard sand & $\begin{array}{l}\text { Feet. } \\
4\end{array}$ & $\begin{array}{l}\text { Feet. } \\
\quad 990\end{array}$ & $\begin{array}{l}\text { Feet. } \\
994\end{array}$ \\
\hline 52 & Bark and logs & 16 & 994 & 1,010 \\
\hline 53 & Blue clay & 11 & 1,010 & 1,021 \\
\hline 54 & Sand $\ldots \ldots$ & 25) & 1,021 & 1,046 \\
\hline 55 & Red clay & 9 & 1,046 & 1,055 \\
\hline 56 & Sand, clay, and bark & 15 & 1,055 & 1,070 \\
\hline 57 & Blue clay ... & 12 & 1,070 & 1,082 \\
\hline 58 & Sand ...... & 23 & 1,082 & 1,105 \\
\hline 59 & Blue clay & 27 & 1,105 & 1,132 \\
\hline 60 & Sand ............ & 21 & 1,132 & 1,153 \\
\hline 61 & Sand and gravel. & 11 & 1,153 & 1,164 \\
\hline 62 & Blue clay & 35 & 1,164 & 1,199 \\
\hline 63 & _....do _... & 4 & 1,199 & 1,203 \\
\hline 64 & Sand . . . . . & 30 & 1,203 & 1,233 \\
\hline 65 & Sand and fine gravel. & 16 & 1,233 & 1,249 \\
\hline 66 & Sand ......... & 55 & 1,249 & 1,304 \\
\hline 67 & Sand and shells . . . & 12 & 1,304 & 1,316 \\
\hline 68 & Blue clay . . . . . . . . & 7 & 1,316 & 1,323 \\
\hline 69 & Soft limestone.... & 2 & 1,323 & 1,325 \\
\hline 70 & Yellow clay . . . . . & 4 & 1,325 & 1,329 \\
\hline 71 & Sand & 30 & 1,329 & 1,359 \\
\hline 72 & Red clay & 12 & 1,359 & 1,371 \\
\hline 73 & Sand and shells ... & $\mathbf{5}$ & 1,371 & 1,376 \\
\hline 74 & Blue clay & 41 & 1,376 & 1,417 \\
\hline 75 & Sand $\ldots . .$. & 37 & 1,417 & 1,454 \\
\hline 76 & Blue clay -.. & 10 & 1,454 & 1,464 \\
\hline 77 & .....do _. & 25) & 1,464 & 1,489 \\
\hline 78 & $\ldots$. $d o \ldots$ & 19 & 1,489 & 1,508 \\
\hline 79 & $\ldots$...do ...... & 23 & 1,508 & 1,531 \\
\hline 80 & Sand . . . . . & 6 & 1,531 & 1,587 \\
\hline 81 & Blue clay .... & 12 & 1,537 & 1,549 \\
\hline 82 & Sand $\ldots \ldots$ & 10 & 1,549 & 1,559 \\
\hline
\end{tabular}

This well has been abandoned as dry. 
Another well in the same vicinity was drilled to a depth of 770 feet and abandoned.

In the sonthwest corner of the Bullock league a well drilled for the Almaden Oil Company to a depth of 1,400 feet gives the following section :

Log of Almaden well in southwest corner of Bullock league, Jefferson County, Tex.

[Elevation, 25 feet.]

\begin{tabular}{|c|c|c|c|c|}
\hline & Character of strata. & Thickness. & From- & To- \\
\hline 1 & Surface clay . . & $\begin{array}{l}\text { Feet. } \\
\qquad 10\end{array}$ & $\begin{array}{l}\text { Feet. } \\
\end{array}$ & $\begin{array}{l}\text { Feet. } \\
\qquad 10\end{array}$ \\
\hline 2 & Orange sand .... & 65 & 10 & 75 \\
\hline 3 & Blue clay ...... & 100 & 75 & 175 \\
\hline 4 & Dark-gray sand & 25 & 175 & 200 \\
\hline 5 & Blue clay ......... . . & 100 & 200 & 300 \\
\hline 6 & Clay and bark. . & 53 & 300 & 353 \\
\hline 7 & Heavy dark-blue clay & 47 & 353 & 400 \\
\hline 8 & Fine sand with wood & 152 & 400 & 552 \\
\hline 9 & Clay & 5 & 552 & 557 \\
\hline 10 & Fine gray sand & 48 & 557 & 605 \\
\hline 11 & Clay ............... & 18 & 605 & 623 \\
\hline 12 & Sand with slight showing of oil & 20 & 623 & 643 \\
\hline 13 & Sandy clay & 82 & 643 & 725 \\
\hline 14 & Fine gray sand ..... & 140 & 725 & 865 \\
\hline 15 & Sandy clay with broken shells . . . . & 130 & 865 & 995 \\
\hline 16 & Fine dark sand & 75 & 995 & 1,070 \\
\hline 17 & Blue sandy clay with broken shells . ..... & 65 & $1,0 \pi 0$ & 1,135 \\
\hline 18 & Fine gray sand ..... & 20 & $1,13 \pi$ & 1,155 \\
\hline 19 & Blue clay and sand & 15 & $1,15 \pi$ & 1,170 \\
\hline 20 & Clay $\ldots \ldots \ldots \ldots$ & 90 & 1,170 & 1,260 \\
\hline 21 & Sand $\ldots \ldots \ldots$ & 140 & 1,260 & 1,400 \\
\hline
\end{tabular}

This well has been abandoned as dry.

South of the Texas and New Orleans Railway (Southern Pacific), in sec. 11, International and Great Northern Railroad lands, the Gulf Coast Oil and Iand Company has drilled a well about 1,500 feet in depth, which gives the following section. 
Log of Gulf Coast Oil and Land Company well in sec. 11, International and Great Northern Railroad Company lands, Jefferson County, Tex.

[Elevation, 25 feet.]

\begin{tabular}{|c|c|c|c|c|}
\hline & Character of strata. & Thickness. & From- & To- \\
\hline & & Feet. & Freet. & Feet. \\
\hline 1 & Red clay & 20 & 0 & 20 \\
\hline 2 & Quicksand ........ & 30 & 20 & 50 \\
\hline 3 & Alternate strata of sand and clay. & 70 & 50 & 120 \\
\hline 4 & Hard blue clay .... & 50 & 120 & 170 \\
\hline 5 & Sand and clay - & 110 & 170 & 280 \\
\hline 6 & Shale $\ldots .$. & 30 & 280 & $\mathbf{3 1 0}$ \\
\hline 7 & Blue clay ......... & 50 & 310 & 360 \\
\hline 8 & Hardpan, traces of oil & 40 & 360 & 400 \\
\hline 9 & Sand and shale & 40 & 400 & 440 \\
\hline 10 & Sand rock. & 1 & 440 & 441 \\
\hline 11 & Red marl shale . & 30 & 441 & 471 \\
\hline 12 & Sand rock & 1 & 471 & 472 \\
\hline 13 & Sand and shale. & 68 & 472 & 540 \\
\hline 14 & Blue clay with cypress $\log s_{-}$ & 40 & 540 & 580 \\
\hline 15 & Rock in thin layers with gravel $\ldots . .$. & 120 & 580 & 700 \\
\hline 16 & $\begin{array}{l}\text { Limestone and sandstone with traces of sul- } \\
\text { phur }\end{array}$ & 80 & 700 & 780 \\
\hline 17 & Hard blue clay . . . . & 50 & 780 & 830 \\
\hline 18 & Rock in thin layers with sand and clay - & 70 & 830 & 900 \\
\hline 19 & Shells and gravel $\ldots$ & 10 & 900 & 910 \\
\hline 20 & Blue clay with small lumps of limestone & 80 & 910 & 990 \\
\hline 21 & Hard blue clay and shell & 10 & 990 & 1,000 \\
\hline 22 & Blue and red clay mixed with shells and gravel & 60 & 1,000 & 1,060 \\
\hline 23 & Thin rock, blue and red clay in layers & ro & 1,060 & 1,130 \\
\hline 24 & Shells and clay ....... & 60 & 1,130 & 1,190 \\
\hline 25 & Clay and shells . . . . . . & 10 & 1,190 & 1,200 \\
\hline 26 & Thin rock and gravel ........ & 50 & 1,200 & 1,250 \\
\hline 27 & Black shale and traces of oil & 30 & 1,250 & 1,280 \\
\hline 28 & Yellow sand . . . . . . . & 20 & 1,280 & 1,300 \\
\hline 29 & Red and blue clay and shells. .. . & 40 & 1,300 & 1,340 \\
\hline 30 & Sharp, coarse sand ... & 20 & 1,340 & 1,360 \\
\hline 31 & Hard blue clay with limestone in hard lumps & 50 & 1,360 & 1,410 \\
\hline 32 & Soft blue clay $\ldots . . .$. & 20 & 1,410 & 1,430 \\
\hline 33 & Sand and clay . . . . . . . . & 20 & 1,430 & 1,450 \\
\hline 34 & Thin rock and gravel .. & 20 & 1,450 & 1,470 \\
\hline 35 & Sharp sand . - & 10 & 1,470 & 1,480 \\
\hline 36 & Hard blue clay ....... & 20 & 1,480 & 1,500 \\
\hline 37 & Gravel and limestone & 16 & 1,500 & 1,516 \\
\hline
\end{tabular}

This well was abandoned as dry. 
On the Caswell tract in the immediate vicinity of Beaumont a well drilled to a depth of 1,518 feet gave the following:

Log of "Caswell well," on Caswell tract, Beaumont, Tex.

[Elevation, 30 feet.]

\begin{tabular}{|c|c|c|c|c|}
\hline & Character of strata. & Thickness. & From- & To- \\
\hline 1 & Clay & \begin{tabular}{l|l} 
Feet. \\
45
\end{tabular} & Fieel. & $\begin{array}{l}\text { Feet. } \\
45\end{array}$ \\
\hline 2 & White sand & 65 & 45 & 110 \\
\hline 3 & Blue clay . . . & 215 & 110 & 325 \\
\hline 4 & Sand $\ldots \ldots \ldots$ & 165 & 325 & 490 \\
\hline 5 & Clay ...... & $185 \frac{1}{2}$ & 490 & $675 \frac{1}{2}$ \\
\hline 6 & Rock showing oil & $\frac{1}{2}$ & $675 \frac{1}{2}$ & 676 \\
\hline 7 & Clay . . . . . & 5 & 676 & 681 \\
\hline 8 & Rock showing oil . . & 1 & 681 & 682 \\
\hline 9 & White quicksand with black specks & 128 & 682 & 810 \\
\hline 10 & Blue clay . . . . & 20 & 810 & 830 \\
\hline 11 & Sand ....... & 40 & 830 & 870 \\
\hline 12 & Blue clay $\ldots \ldots \ldots \ldots$ & 20 & 870 & 890 \\
\hline 13 & Sand, salt water at 930 feet . . . . & 60 & 890 & 950 \\
\hline 14 & Clay and coarse brown sand showing oil & 20 & 950 & 970 \\
\hline 15 & Hard blue clay ... & 30 & 970 & 1,000 \\
\hline 16 & Sand $\ldots \ldots \ldots$ & 50 & 1,000 & 1,050 \\
\hline 17 & Clay and shells. .... & 134 & 1,050 & 1,184 \\
\hline 18 & Hard white clay .... & 13 & 1,184 & 1,197 \\
\hline 19 & Sand showing oil ...... & 6 & 1,197 & 1,203 \\
\hline 20 & $\begin{array}{l}\text { Three beds of limestone with } 1 \text { foot of oil and } \\
\text { asphalt (?) }\end{array}$ & 37 & 1,203 & 1,240 \\
\hline 21 & Oil sand $\ldots \ldots$ & 3 & 1,240 & 1,243 \\
\hline 22 & Clay & 32 & 1,243 & 1,275 \\
\hline 23 & Sand .... & 7 & 1,275 & 1,282 \\
\hline 24 & Clay & 104 & 1,282 & 1,386 \\
\hline 25 & Thin bed of sandstone ... & 2 & 1,386 & 1,388 \\
\hline 26 & Clay ...... & 1 & 1,388 & 1,389 \\
\hline 27 & Sand $\ldots \ldots$ & 17 & 1,389 & 1,406 \\
\hline 28 & Hard red clay drying to light pink & 112 & 1,406 & 1,518 \\
\hline
\end{tabular}

This well was abandoned on account of caving when setting the casing.

South of the above the Bayou City well was drilled on the eastern end of the Iowa Colony lands and east of the Beaumont and Port Arthur public road. This well has a depth of 2,009 feet. No traces whatever of oil have been recorded from the Bayou City well. 
Log of Bayou City well, eastern side of Iowa Colony lands, Jefferson County, Tex.

[Elevation, 25 foot.]

\begin{tabular}{|c|c|c|c|c|}
\hline & Character of strata. & Thicknesss. & From- & To- ! \\
\hline 1 & Red clay ... & $\begin{array}{l}\text { Feet. } \\
\\
18\end{array}$ & $\begin{array}{l}\text { Feet. } \\
\\
\end{array}$ & $\begin{array}{r}\text { Feet. } \\
18\end{array}$ \\
\hline 2 & Red sand & 23 & 18 & 41 \\
\hline 3 & Blue clay & 17 & 41 & 58 \\
\hline 4 & Sand ..... & 20 & 58 & 78 \\
\hline 5 & Clay & 13 & 78 & 91 \\
\hline 6 & Red sand & 2 & 91 & 93 \\
\hline 7 & Blue clay & 8 & 93 & 101 \\
\hline 8 & Sand .... & 1 & 101 & 102 \\
\hline 9 & Blue clay with hard shaly streaks & 128 & 102 & 230 \\
\hline 10 & Blue sand. & 15 & 230 & 245 \\
\hline 11 & White sand . ..... & 11 & 245 & 256 \\
\hline 12 & Blue clay - & 11 & 256 & 267 \\
\hline 13 & Greasy blue clay (called soapstone) & 39 & 267 & 306 \\
\hline 14 & Hard sand .......... & 15 & 306 & 321 \\
\hline 15 & Blue clay same as No. 13 & 9 & 321 & 330 \\
\hline 16 & Gray indurated sand & 16 & 330 & 346 \\
\hline 17 & Blue clay ... & 10 & 346 & 356 \\
\hline 18 & White sandstone & 10 & $35 \mathbf{6}$ & 366 \\
\hline 19 & Indurated sand & 5 & 366 & 371 \\
\hline 20 & Tough red clay .... . & 4 & 371 & 375 \\
\hline 21 & Indurated sand . .... . & 17 & 375 & 392 \\
\hline 22 & Broken shells . & 1 & 392 & 393 \\
\hline 23 & Blue clay . .... & 27 & 393 & 420 \\
\hline 24 & Sand and clay mixed & 13 & 420 & 433 \\
\hline 25 & Fine white sand . . . . & 25 & 433 & 458 \\
\hline 26 & Blue clay - & 66 & 458 & 524 \\
\hline 27 & Blue sand and small gravel. & 55 & 524 & 579 \\
\hline 28 & Shale . & 31 & 579 & 610 \\
\hline 29 & Brown oily clay & 1 & 610 & 611 \\
\hline 30 & Quicksand & 4 & 611 & 615 \\
\hline 31 & Coarse crystalline sand . & 24 & 615 & 639 \\
\hline 32 & Blue clay ... & 41 & 639 & 680 \\
\hline 33 & Clay and sand & 55 & 680 & 735 \\
\hline 34 & Gravel .... . & 35 & 735 & 770 \\
\hline 35 & White sand & 188 & 770 & 958. \\
\hline 36 & Blue clay ... & 409 & 958 & 1,367 \\
\hline 37 & Rock $\ldots \ldots \ldots$ & $\frac{1}{2}$ & 1,367 & $1,367 \frac{1}{2}$ \\
\hline 38 & Sand with salt water. & $92 \frac{7}{2}$ & $1,367 \frac{1}{2}$ & 1,460 \\
\hline 39 & Blue clay - & 51 & 1,460 & 1,511 \\
\hline 40 & White sand & 180 & 1,511 & 1,691 \\
\hline
\end{tabular}


Log of Bayou City well, eastern side of Iowa colony lands, etc.-Continued.

\begin{tabular}{|c|c|c|c|c|}
\hline & Character of strata. & Thickness. & From-- & To-- \\
\hline 41 & Sandstone showing clay. & $\begin{array}{l}\text { Feet. } \\
40\end{array}$ & $\begin{array}{l}\text { Feet. } \\
1,691\end{array}$ & $\begin{array}{l}\text { Feet. } \\
1,731\end{array}$ \\
\hline 42 & Red clay $\ldots \ldots \ldots$ & 26 & 1,731 & 1,757 \\
\hline 43 & Coarse sand with salt water & 9 & 1,757 & 1,766 \\
\hline 44 & Very fine white sand . & 14 & 1,766 & 1,780 \\
\hline 45 & White clay and blue sand & 3 & 1,780 & 1,783 \\
\hline 46 & Sand with broken shells. & 28 & 1,783 & 1,811 \\
\hline 47 & Compact white sand & 14 & 1,811 & 1,825 \\
\hline 48 & Sand and clay $\ldots \ldots$ & 27 & 1,825 & 1,852 \\
\hline 49 & $\begin{array}{l}\text { Coarse white sand with shells and wood, } \\
\text { Mulinea balanus sp., and fish bones }\end{array}$ & 18 & 1,852 & 1,870 \\
\hline 50 & Coarse sand, shells, and wood $\ldots \ldots$ & 30 & $1,8 \% 0$ & 1,900 \\
\hline 51 & 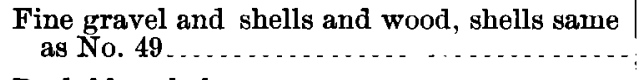 & 10 & 1,900 & 1,910 \\
\hline 52 & Dark-blue shale $\ldots \ldots \ldots$ & 7 & 1,910 & 1,917 \\
\hline 53 & Blue clay $\ldots \ldots \ldots \ldots$ & 18 & $1,91 \%$ & 1,935 \\
\hline 54 & Red clay & 16 & $1,93 \overline{5}$ & 1,951 \\
\hline 55 & Blue clay with pockets of soft white sand & 58 & 1,951 & 2,009 \\
\hline
\end{tabular}

Northwest of Spindletop the character of the beds underlying this portion of the field is well shown in the records of the Harby well on the Chaison tract, elose to the Texas and New Orleans Railway line. This well has been drilled to a depth of 1,840 feet and the drill is still at work (June, 1902).

Log of Harby well, Jeff Chaison tract, Jefferson County, Tex.

[Elevation, 30 feet.]

\begin{tabular}{|c|c|c|c|c|}
\hline & Character of strata. & Thickness. & From- & To- \\
\hline 1 & Clay & $\begin{array}{l}\text { Feet. } \\
\quad 34\end{array}$ & $\begin{array}{l}\text { Feet. } \\
\\
0\end{array}$ & $\begin{array}{l}\text { Feet. } \\
\quad 34\end{array}$ \\
\hline 2 & Sand . . . & 4 & 34 & 38 \\
\hline 3 & Clay & $\gamma$ & 38 & 45 \\
\hline 4 & Sand with shells and wood & $\tilde{\mathbf{5}}$ & 45 & 50 \\
\hline 5 & Clay ..................... & 20 & 50 & 70 \\
\hline 6 & Clean white sand & $\overline{5}$ & 70 & 75 \\
\hline 7 & Clay .... & 25 & 75 & 100 \\
\hline 8 & Sand & 68 & 100 & 168 \\
\hline 9 & Shale $\ldots \ldots$ & 14 & 168 & 182 \\
\hline 10 & Blue clay ..... & 46 & 182 & 228 \\
\hline 11 & Rock $\ldots \ldots \ldots$ & 2 & 228 & 230 \\
\hline 12 & Blue clay ...... & 26 & 230 & 256 \\
\hline
\end{tabular}


Log of Harley well, Jeff Chaison tract, Jefferson County, Tex.-Continued.

\begin{tabular}{|c|c|c|c|c|}
\hline & Character of strate. & Thickness. & From- & To- \\
\hline 13 & Rock & $\begin{array}{l}\text { Feet. } \\
4\end{array}$ & $\begin{array}{l}\text { Feet. } \\
\quad 256\end{array}$ & $\begin{array}{l}\text { Feet. } \\
\quad 260\end{array}$ \\
\hline 14 & $\begin{array}{l}\text { Soft blue clay with } \log \text { at } 290 \text { feet; yellow } \\
\text { streaks and some shells }\end{array}$ & 30 & 260 & 290 \\
\hline 15 & Yellow clay with log at 340 feet & 50 & 290 & 340 \\
\hline 16 & Sand ...... & 65 & 340 & 405 \\
\hline 17 & Blue clay . . . . . . & 77 & 405 & 482 \\
\hline 18 & Hard rock $\ldots . . . .$. & 1 & 482 & 483 \\
\hline 19 & Soft blue clay & 9 & 483 & 492 \\
\hline 20 & Sand & 16 & 492 & 508 \\
\hline 21 & Blue clay . . . . & 42 & 508 & 550 \\
\hline 22 & Sand . . . . . . & $\mathbf{5}$ & 550 & 555 \\
\hline 23 & Yellow clay . ... & 15 & 555 & 570 \\
\hline 24 & Lignite & 1 & 570 & 571 \\
\hline 25 & Sand & 4 & 571 & 575 \\
\hline 26 & Clay ............. & 29 & 575 & 604 \\
\hline 27 & Hard rock. .... & 8 & 604 & 612 \\
\hline 28 & Soft blue clay ... & 12 & 612 & 624 \\
\hline 29 & Shale rock $\ldots \ldots \ldots \ldots$ & 24 & 624 & 648 \\
\hline 30 & Blue clay and shale, very hard in streaks & 50 & 648 & 698 \\
\hline 31 & Fine white sand & 18 & 698 & 716 \\
\hline 32 & Hard blue shale with thin layers of sand & 19 & 716 & 735 \\
\hline 33 & $\begin{array}{l}\text { Shale mixed with coarse sand; sand sharp } \\
\text { with black and yellow specks }\end{array}$ & 29 & 735 & 764 \\
\hline 34 & $\begin{array}{l}\text { White sand; upper } 30 \text { feet hard in streak, } \\
\text { last } 30 \text { feet showing black specks....... }\end{array}$ & 110 & 764 & 874 \\
\hline 35 & Blue clay . . . ... & 2 & 874 & 876 \\
\hline 36 & Coarse sand & 10 & 876 & 886 \\
\hline 37 & Blue clay with some shale & 56 & 886 & 942 \\
\hline 38 & Sand $\ldots . .$. & 8 & 942 & 950 \\
\hline 39 & Blue shale with shells $\ldots \ldots$ & 10 & 950 & 960 \\
\hline 40 & Sand with indications of oil. & 4 & 960 & 964 \\
\hline 41 & Blue shale $\ldots \ldots \ldots$ & 3 & 964 & 967 \\
\hline 42 & Hard white rock &  & 967 & $967 \frac{1}{4}$ \\
\hline 43 & Soft blue clay and shells & $35 \frac{8}{4}$ & $967 \pm$ & 1,003 \\
\hline 44 & Sand $\ldots$ & 10 & 1,003 & 1,013 \\
\hline 45 & $\begin{array}{l}\text { Soft blue clay, with yellowish sand and lig- } \\
\text { nite and shells, indications of oil at } 1,065- \\
1,071 \ldots \ldots\end{array}$ & 199 & 1,013 & 1,212 \\
\hline 46 & Rock $\ldots$ & 1 & 1,212 & $1,212 \frac{1}{4}$ \\
\hline 47 & Fine white sand & $5 \frac{8}{4}$ & 1,2127 & 1,218 \\
\hline 48 & Blue clay & 46 & 1,218 & 1,264 \\
\hline 49 & Fine white sand & 3 & 1,264 & 1,267 \\
\hline
\end{tabular}


Log of Harley well, Jeff Chaison tract, Jefferson County, Tex.-Continued.

\begin{tabular}{|c|c|c|c|c|}
\hline & Character of strata. & Thickness. & From-- & $T w-$ \\
\hline 50 & Hard blue clay with some shells & Feet. & $\begin{array}{l}\text { Feet. } \\
1, \mathfrak{2 6} \%\end{array}$ & $\begin{array}{l}\text { Feet. } \\
1,280\end{array}$ \\
\hline 51 & Red clay ........ & 37 & 1,280 & 1,317 \\
\hline 52 & Fine gray sand . . . . . . . . & 40 & 1,317 & 1,357 \\
\hline 53 & Red and blue clay .... & 23 & $1,35 \pi$ & 1,380 \\
\hline 54 & Fine white sand $\ldots \ldots \ldots$ & 10 & 1,380 & 1,390 \\
\hline 55 & Blue, red, and brownish clay & 4 & 1,390 & 1,394 \\
\hline 56 & $\begin{array}{l}\text { Blue and red hard clay, with streaks of rock } \\
\text { from a few inches to } 2 \text { feet, mostly lime- } \\
\text { stones. Strong indications of oil between } \\
1,450 \text { and } 1,460\end{array}$ & $20 \overline{5}$ & 1,394 & $1, \tilde{599}$ \\
\hline 57 & $\begin{array}{l}\text { Blue clay with streaks of limestone from } 2 \\
\text { inches to } 2 \text { feet }\end{array}$ & 15 & 1,599 & 1,614 \\
\hline 58 & $\begin{array}{l}\text { Red, blue, and brown clay with limestone } \\
\text { rock; mostly rock }\end{array}$ & 9 & 1,614 & 1,623 \\
\hline 59 & Light-blue clay $\ldots \ldots \ldots \ldots \ldots \ldots$ & 2 & 1,623 & 1,625 \\
\hline 60 & $\begin{array}{l}\text { Limestones in thin layers with a few inches } \\
\text { of mud between }\end{array}$ & 24 & 1,625 & 1,649 \\
\hline 61 & Fine white sand with blue clay and limestone. & 12 & 1,649 & 1,661 \\
\hline 62 & $\begin{array}{l}\text { Blue clay mixed with some limestone and } \\
\text { sandstone } \ldots\end{array}$ & 8 & 1,661 & 1,669 \\
\hline 63 & Sandstone with thin deposits of clay & 31 & 1,669 & 1,700 \\
\hline 64 & Blue clay with streaks of limestone and pyrites & 5 & 1,700 & 1,705 \\
\hline 65 & $\begin{array}{l}\text { Sandstone with small quartz crystals and } \\
\text { black specks and indications of oil at } 1,735 .\end{array}$ & 38 & $1,70 \pi$ & 1.743 \\
\hline 66 & Fine white sand with indications of oil at 1,761 & 20 & 1,743 & 1,763 \\
\hline 67 & Blue and red clay and shale and mud & 31 & 1,763 & 1,794 \\
\hline 68 & $\begin{array}{l}\text { Limestone with some very dark-red and blue } \\
\text { clay } \ldots\end{array}$ & 41 & 1,794 & 1,835 \\
\hline 69 & Limestone $\ldots . . . . . . . .$. & 2 & 1,835 & 1,837 \\
\hline 70 & Limestone and clay ... & 3 & $1,83 \pi$ & 1,840 \\
\hline
\end{tabular}

In this well small seeps or pockets of petroleum were found at several depths between 805 and 1,761. Fairly strong indications of oil appeared between 1,450 and 1,460 , and again between 1,743 and 1,761. Salt water having a strong flow also appeared at 1,830 feet, and small flows of gas were found.

The Slaughter-Masterson well located on Lot 2 of the Veatch survey is one of the deepest wells. in the field, having reached a depth of 2,250 feet. From its location as well as depth it is one of the most important holes drilled in this section. The following log has been supplied by Mr. Andrews, manager of the company. Owing to the death of the driller who was in charge at the beginning, the log of the first 360 feet can not be given.

Bull. 212-03-7 
The well is about midway between the Harby well and the Jones Development Company's producing well on lot 44 of Gladys City, and the producing well of the Denver-Beaumont Company on lot No. 5 of Spindletop Heights. The Denver well flows at 1,108 feet. Comparison and correlation of these well records should afford a fair knowledge of the structure of that portion of the plain lying to the northwest of the producing field at Spindletop.

Log of Slaughter-Nasterson well on lot 2 of Veatch survey.

[Elevation, 25 feet.]

\begin{tabular}{|c|c|c|c|c|}
\hline & Character of strata. & Thickness. & From- & To- \\
\hline 1 & From surface to 360 feet lost. & $\begin{array}{l}\text { Feet. } \\
\qquad 360\end{array}$ & $\begin{array}{c}\text { Feet. } \\
0\end{array}$ & $\begin{array}{l}\text { Feet. } \\
\quad 360\end{array}$ \\
\hline 2 & Tough blue clay .......... & 40 & 360 & 400 \\
\hline 3 & Alternate layers of gray clay and sandstone & 20 & 400 & 420 \\
\hline 4 & Gray clay . & 131 & 420 & 551 \\
\hline 5 & Shelly rock ..... & 47 & 551 & 598 \\
\hline 6 & Bowlders . . . . . . . . & 5 & 598 & 608 \\
\hline 7 & Gray clay and sand & 2 & 603 & 605 \\
\hline 8 & Hard gray sand & 32 & 605 & 637 \\
\hline 9 & Gray clay $\ldots \ldots \ldots \ldots$ & 33 & 637 & 670 \\
\hline 10 & Limestone ............ & 1 & 670 & 671 \\
\hline 11 & Gray clay with sandstone. & 27 & 671 & 698 \\
\hline 12 & Hard sand; show of oil & 3 & 698 & 701 \\
\hline 13 & Gray clay . .... & 30 & 701 & 731 \\
\hline 14 & Gray sand with show of oil and gas & 59 & 731 & 790 \\
\hline 15 & Clay and sand $\ldots \ldots \ldots$ & 11 & 790 & 801 \\
\hline 16 & $\begin{array}{c}\text { Coarse pebbly sand with sandstone and some } \\
\text { gas }\end{array}$ & 45 & 801 & 846 \\
\hline 17 & Hard sandstone ..... & 2 & 846 & 848 \\
\hline 18 & Soft gray clay $\ldots \ldots \ldots \ldots$ & 16 & 848 & 864 \\
\hline 19 & Hard gray sandstone with marl & 9 & 864 & 873 \\
\hline 20 & Gumbo (blue clay) & 14 & 873 & 887 \\
\hline 21 & Soft gray sand & 13 & 887 & 900 \\
\hline 22 & Soft blue clay showing oil & 22 & 900 & 922 \\
\hline 23 & White sand showing gas. & 8 & 922 & 930 \\
\hline 24 & Blue clay with shells & 11 & 930 & 941 \\
\hline 25 & Hard gray sandstone & 12 & 941 & 953 \\
\hline 26 & Soft fine sand - & 41 & 953 & 994 \\
\hline 27 & Shells ............ & 7 & 994 & 1,001 \\
\hline 28 & Clay with shells . . . . & 19 & 1,001 & 1,020 \\
\hline 29 & Shells with a little limestone... & 28 & 1,020 & 1,048 \\
\hline 30 & Hard gray sand ..... & 13 & 1,048 & 1,061 \\
\hline 31 & Blue clay with hard streaks and shells. & 108 & 1,061 & 1,169 \\
\hline 32 & Hard sand & 4 & 1,169 & 1,173 \\
\hline
\end{tabular}


Log of Slaughter-Masterson well on lot \& of Veateh survey-Continued.

\begin{tabular}{|c|c|c|c|c|}
\hline & Character of strata. & Thickness. & From- & To- \\
\hline 33 & Soft gray clay & Feet. 7 & $\begin{array}{l}\text { Feet. } \\
1,173\end{array}$ & $\begin{array}{l}\text { Feet. } \\
1,180\end{array}$ \\
\hline 34 & Hard blue clay & 14 & 1,180 & 1,194 \\
\hline 35 & Limestone with thin layers of clay & 29 & 1,194 & 1,223 \\
\hline 36 & Clay ... & 47 & 1,223 & 1,270 \\
\hline 37 & $\begin{array}{l}\text { Thin layers of limestone with some gas, hard } \\
\text { in lower division }\end{array}$ & 58 & 1,270 & 1,328 \\
\hline 38 & Gray sand showing oil and gas. & 57 & 1,328 & 1,385 \\
\hline 39 & Hard limestone. - & 2 & 1,385 & 1,387 \\
\hline 40 & Hard clay . . . . . . . . & 10 & 1,387 & 1,397 \\
\hline 41 & Hard blue limestone. .... . . & 1 & 1,397 & 1,398 \\
\hline 42 & Pebbly concrete & 2 & 1,398 & 1,400 \\
\hline 43 & Soft white lime with iron pellets & 12 & $1,400^{\circ}$ & 1,412 \\
\hline 44 & Coarse gray sand $\ldots . .$. & 5 & 1,412 & 1,417 \\
\hline 45 & $\begin{array}{l}\text { Limestones interstratified with blue and red } \\
\text { clays and sand with pyrites................... }\end{array}$ & 135 & 1,417 & 1,552 \\
\hline 46 & Conglomerate . . . . . . . . . & 18 & 1,552 & 1,570 \\
\hline 47 & Clay with thin layers of limestone & 30 & 1,570 & 1,600 \\
\hline 48 & Very hard bed of limestone & 8 & 1,600 & 1,608 \\
\hline 49 & Yellow sand . & 10 & 1,608 & 1,618 \\
\hline 50 & Soft limestone & 17 & 1,618 & 1,635 \\
\hline 51 & ood and iron pyrites. & 30 & 1,635 & 1,665 \\
\hline 52 & Soft reddish clay . . . . . . . . & 15 & 1,665 & 1,680 \\
\hline 53 & Blue limestone with sand and pebbles & 21 & 1,680 & 1,701 \\
\hline 54 & Soft & 55 & 1,701 & 1,756 \\
\hline 55 & White sandstone $\ldots \ldots \ldots$ & 11 & 1,756 & 1,767 \\
\hline 56 & Limestone with pink pebbles .... & 8 & 1,767 & 1,775 \\
\hline 57 & $\begin{array}{l}\text { Coarse gray sandstone with some lime in } \\
\text { lower division }\end{array}$ & 69 & 1,775 & 1,844 \\
\hline 58 & Gray c & 24 & 1,844 & 1,868 \\
\hline 59 & Sandstone with lime. & 27 & 1,868 & 1,895 \\
\hline 60 & Tough red clay $\ldots \ldots \ldots$ & 14 & 1,895 & 1,909 \\
\hline 61 & Gray and pink limestone & 5 & 1,909 & 1,914 \\
\hline 62 & Blue clay and red clay $\ldots$ & 20 & 1,914 & 1,934 \\
\hline 63 & Sandstone . . . . . . . . . . . & 11 & 1,934 & 1,945 \\
\hline 64 & White limestone with iron pyrites & 20 & 1,945 & 1,997 \\
\hline 65 & Limestone & 35 & 1,997 & 2,032 \\
\hline
\end{tabular}

In the same belt, along the northern side of the hill, are the Treadway and Allyne wells, which have been drilled to depths exceeding 1,800 and 2,000 feet. In the Treadway the general series of sands, clays, and sandstones occurs, with occasional seeps of oil and proba- 
bly gas, although none of the latter has been reported. A condensed $\log$ of the Treadway shows the following section:

Log of Treaduay well, on lot st, Gladys City.

[Elevation, 25 feet.]

\begin{tabular}{|c|c|c|c|c|}
\hline & rata. & Thickness. & From- & To- \\
\hline 1 & Blue and yellow clay and sand . & $\begin{array}{l}\text { Feet. } \\
\quad 269\end{array}$ & $\begin{array}{l}\text { Feet. } \\
\quad 0\end{array}$ & $\begin{array}{l}\text { Feet. } \\
\quad 269\end{array}$ \\
\hline 2 & Sand rock and shells . . . . . . . . & 22 & 269 & 291 \\
\hline 3 & $\begin{array}{l}\text { Blue clay with shells and occasional thin } \\
\text { layers of sandstone }\end{array}$ & 102 & 291 & 393 \\
\hline 4 & Sandstone . . & 14 & 393 & 407 \\
\hline 5 & Blue clay with indications of oil at 413 feet & 25 & 407 & 432 \\
\hline 6 & gray sand with gravel in last 18 feet & 40 & 432 & 472 \\
\hline 7 & nd and shells . & 21 & 472 & 493 \\
\hline 8 & ndstone & $\mathfrak{2} 2$ & 493 & 515 \\
\hline 9 & Blue & 10 & 515 & 525 \\
\hline 10 & Blue & 64 & 525 & 589 \\
\hline 11 & Sandstones, gray, with brown gravel. ... & 30 & 589 & 619 \\
\hline 12 & Sand & 21 & 619 & 640 \\
\hline 13 & le and clay & 42 & 640 & 682 \\
\hline 14 & Soft white rock $\ldots .$. & 21 & 682 & 803 \\
\hline 15 & Gray quicksand $\ldots \ldots \ldots \ldots \ldots$ & 151 & 703 & 854 \\
\hline 16 & Brown sandstone with gray and white sand & 70 & 854 & 924 \\
\hline 17 & Blue clay & $\ldots$ & 924 & \\
\hline 18 & Strata of limestones, sands, and clays & 300 & 1,500 & 1,800 \\
\hline
\end{tabular}

'This well has been abandoned as dry at 2,250 feet.

The $\log$ of the Allyne shows a somewhat similar series of beds. However, in this well much more gravel appears to have been encountered than in any other well in this district the record of which is available.

Log of Allyne well, on lot 28, Iowa Colony, Jefferson County, Tex.

[Elevation, $\approx 2$ feet.]

\begin{tabular}{|c|c|c|c|c|}
\hline & Character of strata. & Thickness. & From-- & To- \\
\hline & & Feet. & Feet. & Feet. \\
\hline 1 & Sands and clays & 800 & 0 & 800 \\
\hline 2 & $\begin{array}{l}\text { Clear fine gravel or coarse sand with strata of } \\
\text { limestone }\end{array}$ & 50 & 800 & 850 \\
\hline 3 & Very fine quicksand with artesian water $\ldots . .$. & 32 & 850 & 882 \\
\hline 4 & Wanting .................... & 118 & 882 & 1,000 \\
\hline
\end{tabular}


Log of Allyne well, on lot 28, Iowa Colony, Jefferson County, Tex.-Continued.

\begin{tabular}{|c|c|c|c|c|}
\hline & Character of strata. & Thickness. & From- & To- \\
\hline 5 & $\begin{array}{l}\text { Sand, sandstone with gravel and shells; salt } \\
\text { water at } 1,050\end{array}$ & $\begin{array}{l}\text { Feet. } \\
\text { ii) }\end{array}$ & $\begin{array}{l}\text { Feet. } \\
\qquad 1,000\end{array}$ & $\begin{array}{l}\text { Feet. } \\
\qquad 1,075\end{array}$ \\
\hline 6 & $\begin{array}{l}\text { Blue clay with occasional beds of gravel and } \\
\text { sand }\end{array}$ & 470 & 1,075 & 1,545 \\
\hline$\tau$ & $\begin{array}{l}\text { Pinkish-colored limestone with clays inter- } \\
\text { stratified }\end{array}$ & 180 & $1, \overline{5} 45$ & 1,725 \\
\hline 8 & Gravel with a thin bed of blue clay $\ldots$ & 30 & 1,725 & 1,755 \\
\hline 9 & $\begin{array}{l}\text { Thin limestone beds with gravel, sand, and } \\
\text { some clay }\end{array}$ & 145 & 1,755 & 1,900 \\
\hline 10 & Sand $\ldots \ldots$ & 55 & 1,900 & 1,955 \\
\hline 11 & $\begin{array}{l}\text { Blue, red, and chocolate-colored clay with } \\
\text { thin streaks of rock }\end{array}$ & 60 & $1,95 \overline{3}$ & 2,015 \\
\hline
\end{tabular}

This well has been abandoned as dry.

On the eastern side of the field and in a position that might lie directly in the eastern extension of the Spindletop field is the United States well. This well has been drilled to a depth of 2,075 feet and abandoned as dry. Oil seeps of considerable size occurred at various levels.

Log of United States well east of Spindletop, on Bullock league.

[Elevation, 24 feet.]

\begin{tabular}{|c|c|c|c|c|}
\hline & Character of strata. & Thickness. & From- & To- \\
\hline 1 & Clay and sand . & $\begin{array}{l}\text { Fret. } \\
\qquad 180\end{array}$ & $\begin{array}{l}\text { Feet. } \\
\\
0\end{array}$ & $\begin{array}{l}\text { Feet. } \\
180\end{array}$ \\
\hline 2 & Sandstone & 66 & 180 & 246 \\
\hline 3 & Clay & 4 & 246 & 250 \\
\hline 4 & Sandstone $\ldots . . . . . .$. & 10 & 250 & 260 \\
\hline 5 & Hard blue clay & 114 & 260 & 374 \\
\hline 6 & Rock with thin stratum of sand & $10 \pi$ & 374 & 481 \\
\hline 7 & Sand with slight traces of oil at 500 feet. & 49 & 481 & 530 \\
\hline 8 & Hard rock & 30 & 530 & 560 \\
\hline 9 & Record wanting & 50 & 560 & 610 \\
\hline 10 & Blue clay $\ldots \ldots$ & 70 & 610 & 680 \\
\hline 11 & Sand and gravel with gas at $724 \ldots$ & 161 & 680 & 841 \\
\hline 12 & Blue clay . ... & 9 & 841 & 850 \\
\hline 13 & Blue sand with traces of oil at 860 & 30 & 850 & 880 \\
\hline 14 & Blue clay with traces of oil & 20 & 880 & 900 \\
\hline 15 & Sand ........ & 21 & 900 & 921 \\
\hline 16 & Blue clay with loose rock and traces of oi & 116 & 921 & 1,037 \\
\hline
\end{tabular}


Log of United States well east of Spindletop, on Bullock league-Continued.

\begin{tabular}{|c|c|c|c|c|}
\hline & Character of strata. & Thickness. & From- & To- \\
\hline & & Feet. & Feet. & Feet, \\
\hline 17 & Gray sand with indications of oil at $1,15,5$ feet. & 199 & 1,037 & 1,236 \\
\hline 18 & Blue clay . . . . . . . . . . & 4 & 1,236 & 1,240 \\
\hline 19 & Sand with shells......... & 108 & 1,240 & 1,348 \\
\hline 20 & Hard rock $\ldots \ldots \ldots \ldots \ldots$ & 4 & 1,348 & 1,352 \\
\hline 21 & Sand with shells . ... . . . . . . . & 23 & 1,352 & 1,375 \\
\hline 22 & Blue and red clays ....... & 35 & 1,375 & 1,410 \\
\hline 23 & Sandstone with oil indications below . & 90 & 1,410 & 1,500 \\
\hline 24 & Sand with strong indications of oil. .... & 30 & 1,500 & 1,530 \\
\hline 25 & Soft mud. & 53 & 1,530 & 1,583 \\
\hline 26 & Sand with shells and indications of oil & 107 & 1,583 & 1,690 \\
\hline 27 & Soft sand with indications of oil & 30 & 1,690 & 1,720 \\
\hline 28 & Sandstone and sand with oil in sand .... & 80 & 1,720 & 1,800 \\
\hline 29 & $\begin{array}{l}\text { Red and blue clay with slight indications of } \\
\text { oil }\end{array}$ & 15 & 1,800 & 1,815 \\
\hline 30 & Soft mul ..... & 20 & 1,815 & 1,835 \\
\hline 31 & Sand. & 65 & 1,835 & 1,900 \\
\hline 32 & Soft mud . . . . . & 50 & 1,900 & 1,950 \\
\hline 33 & Sand ......... & 50 & 1,950 & 2,000 \\
\hline 34 & Blue clay . ...... & 50 & 2,000 & 2,050 \\
\hline 35 & Coarse sand and shells. . - & 25 & 2,050 & 2,075 \\
\hline
\end{tabular}

West and south of Spindletop wells have been drilled to depths ranging from 1,200 to 2,400 feet. None of these records are available, but in general the deposits drilled through were similar in character to those found in the wells along the north and northwestern edges of this lower field. All these wells have been abandoned, with the exception of the Federal Crude. This latter well, which in June, 1902, reached a depth of 2,350 feet, passed through considerable quantities of gas between 2,000 and 2,100 feet. Between 2,200 and 2,350 the drill was in gray sandstone with shells and pyrites, with considerable gas. These clays and sandstones may possibly be an extension of the clays and sandstones found at Rockland and westward along the Neches River to Corrigan, in Polk County, and form the floor on which the beds grouped as the Coastal Plain formations were laid down.

This well is the most important one drilling on the western side of the field. It is located in an almost direct line along the course of the Spindletop anticline and may be expected to decide the question as to the conditions under which the oil-bearing rocks occur in their westward extension. 
LIST OF WELLS.

Dry and abandoned wells in region surrounding Spindletop pool.

[May 31, 1902.]

\begin{tabular}{|c|c|c|c|}
\hline $\begin{array}{c}\text { No. } \\
\text { on } \\
\text { map. }\end{array}$ & Name. & Locration. & Depth. \\
\hline & & & Fret. \\
\hline 1 & Carroll. & Beaumont..... & 800 \\
\hline 2 & Caswell & Caswell tract ... & 1,518 \\
\hline 3 & Pear Orchard & J. Garrison tract $\ldots$ & 1,460 \\
\hline 4 & Harby & Jas. Chaison tract & 1,900 \\
\hline 5 & Swartz _ & J. D. Polk, Bullock league & 2,300 \\
\hline 6 & Almaden . & Henry Lewis, Bullock league. & 1,400 \\
\hline 7 & El Beaumont . . & Iowa Colony & 1,600 \\
\hline 8 & Texas and California & _. _ do & - \\
\hline 9 & Temple-Beaumont. & _....do - - & 1,200 \\
\hline 10 & Texas Western & . _ do . _. & 1,500 \\
\hline 11 & & Block 15, Bullock league & 1,200 \\
\hline 12 & Bayou City - & East side of Bullock league & 2,000 \\
\hline 13 & Allyne & Block 28, Bullock league & 2,015 \\
\hline 14 & Texas and Pacific & Iowa Colony . . . . . . & 1,513 \\
\hline 15 & Maskamp & Block 33, Bullock league & 1,200 \\
\hline 16 & Garrick . & Block 15, Veatch league & 1,135 \\
\hline 17 & Kiser-Kelly & Block 6, Veatch league & 1,860 \\
\hline 18 & Treadway ... & Block 36, Veatch league .. & 2,414 \\
\hline 19 & West Texas & Block 31, Bullock leagne & 1,527 \\
\hline 20 & Warren .... & do & 1,200 \\
\hline 21 & Chicago Crude & Block 21, Veatch league. - & 2,160 \\
\hline 22 & Slaughter-Masterson & Block 2, Veatch league . & 2,250 \\
\hline 23 & Beaumont and Los Angeles & Block 21, Veatch league & 1,200 \\
\hline 24 & Beaumont and El Paso & Block 113, Veatch league & \\
\hline 25 & Beaumont and Pacific Slope & Block 111, Veatch league. & \\
\hline 26 & Grace .... & Block 132, Veatch league. . & $\ldots$ \\
\hline 27 & Bryan Heard . & James Rowe tract. & 1,280 \\
\hline 28 & Buffalo - & J. Douthet survey & 1,400 \\
\hline 29 & Federal Crude & .... do & 2,400 \\
\hline 30 & Trenton Rock & .....do _. & 1,500 \\
\hline 31 & Southern Pacific. & Railroad right of way & $\ldots$. \\
\hline 32 & Neches _. & Block 9, Spindletop & 1,200 \\
\hline 33 & Spangler & Block 10, Spindletop . . & 1,500 \\
\hline 34 & Roby & Block 8, Spindletop ...... & 1,135 \\
\hline 35 & Big Jumbo & Block $\%$, Spindletop & 2,000 \\
\hline 36 & Stribling . & Block 44, Spindletop & 1,510 \\
\hline 37 & Gober No. 1 & Block 42, Spindletop & 1,840 \\
\hline
\end{tabular}


Dryand abandoned wells in region surrounding Spindletop pool-Continued.

\begin{tabular}{|c|c|c|c|}
\hline $\begin{array}{c}\text { No. } \\
\text { on } \\
\text { map. }\end{array}$ & Name. & Location. & Depth. \\
\hline & & & Feet. \\
\hline 38 & United States. & East end of Spindletop...... & 2,100 \\
\hline 39 & Hebert $\ldots .$. & Humphrey's leagne ... _ & 2,000 \\
\hline 40) & MeFaddin Oil and Gas & Lot 144, Hnmphrey's leagne & 1,500 \\
\hline 41 & $\ldots d o$ & Block 31, W. Carrol league. & 1,500 \\
\hline 42 & Island . . . & Smith Island & 1,500 \\
\hline 43 & McClner No. 1 & Humphrey's leagne . . . & 1,170 \\
\hline 44 & McCluer No. $2 \ldots$ & $\ldots$ do $\ldots$......... & 1,878 \\
\hline 45 & Acme Oil and Fuel Co & Veatch leagne . . . . . . . . & 2,160 \\
\hline 46 & Queen of Waco & Block 11, Veatch leagne ...... & $\ldots$ \\
\hline $4 \pi$ & Madeline ... & Block 108, Gladys. . . . . . . . . . & $\ldots$ \\
\hline 48 & Gravier & Stephenson league, Orange County & 1,500 \\
\hline 49 & Sanger .. & D. Easley ... & 1,500 \\
\hline 5) & Walker - - & $\ldots$. . do $\ldots . .$. & $\ldots$ \\
\hline 51 & Decker . & $\begin{array}{l}\text { South half Stephenson league, Or- } \\
\text { ange County. }\end{array}$ & 1,200 \\
\hline 52 & Central & 3 miles south of Lucas ... & 2,315 \\
\hline
\end{tabular}

PORT ARTHUR-SABINE PASS DISTRICT.

This district includes an ill-defined region on the Gulf coast around and between the two towns named and extending some distance into the Gulf. Although several test wells have been put down to moderate depths, no producing territory has yet been developed, and the chief promise in the district is afforted by the so-called "oil ponds" in the Gulf and the undoubted presence of oil in the mud at the mouth of the Sabine River.

\section{OIL PONDS.}

Situated a short distance offshore and within :3 miles west of the mouth of the Sabine are two small oval areas less than a mile in longer diameter, in which the water is always relatively smooth. The approximate size and location of these areas are shown on the accompanying map, fig. 4. This peculiarity of the water in these areas, but particularly the westernmost of the two, has been known to local pilots, fishermen, and others for many years. It is stated on reliable authority that no matter how havy the sea may be on surrounding portions of the Gulf, within these restricted areas it never breaks, and this fact is constantly taken advantage of by coasting vessels, which find here a safe anchorage during storms. The commonly accepted explanation of this peculiarity, among sailors and others, is that oil 
coming from submarine springs spreads over the surface of the water for a short distance around the vents, and thus prevents the waves breaking. So widespread is this view that accounts of these "oil ponds" are common in the literature relating to the use of oil on the water during storms at sea. It does not appear, however, that any oil film has ever been observed on the surface of these portions of the Gulf, and the commonly accepted explanation merely rests on an inference from the observed effect of oil artificially applied.

Dr. W. B. Phillips ${ }^{a}$ accepts the facts above stated, but offers another explanation, namely, that the quiet water is due not to oil, but to the presence upon the Gulf bottom of very fine mud containing a large amount of decayed organic matter which is stirred up by the waves

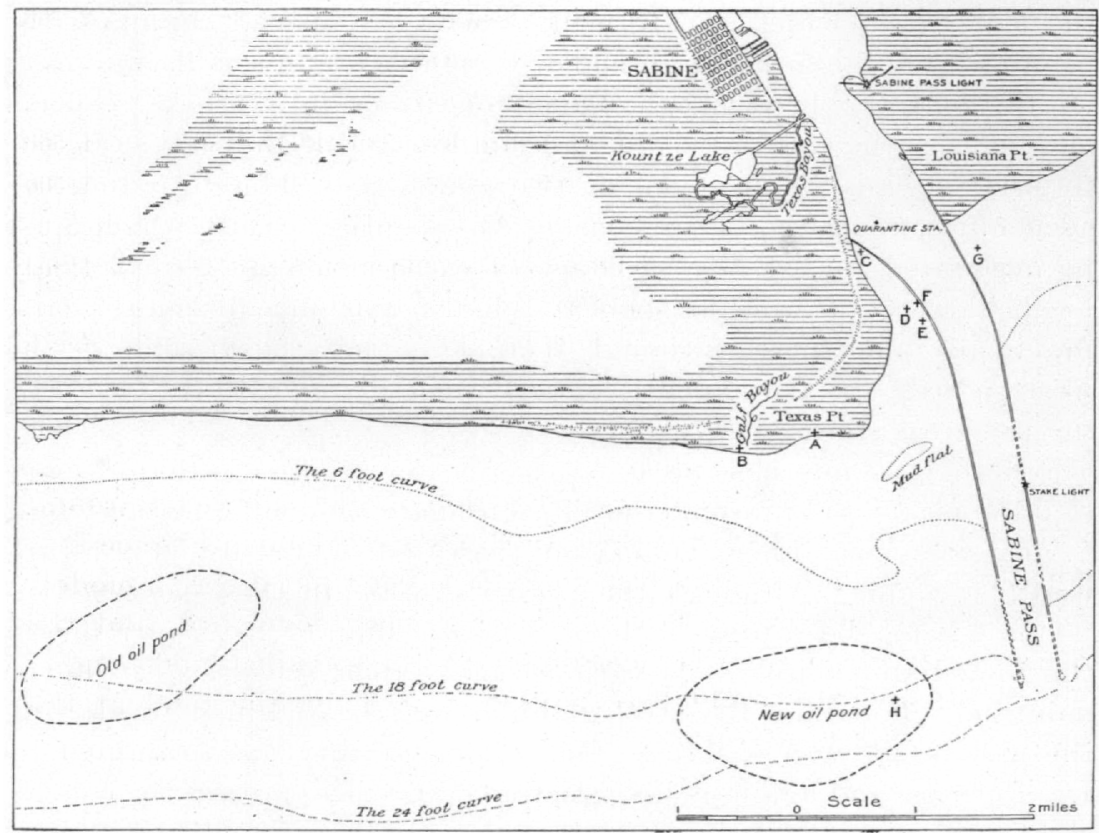

FIG. 4.-Map of Sabine Pass, showing location of so-called oil ponds.

and produces the same effect as oil spread upon the surface. Quoting Dr. Phillips's words:

The true explanation of the so-called oil pond appears to be as follows: The bottom of the sea there is composed, for the most part, of a thick black mud in which are embedded various animal and vegetable remains. . Under the incipient decomposition that is nearly always in progress in such material, substances of a more or less oily nature are formed. The absorption or segregation of oil by means of certain diatoms may also have contributed to the presence of oily substances in the ooze. When this mass becomes stirred up by wave action and diffuses itself through the water, rising even to the surface, the roughness of the water is affected 
in a manner comparable with the action of oil. The soundings in the so-called oil pond, according to Chart No. 203 of the United States Coast and Geodetic Survey, vary from 4 to 16 feet, while outside of the shallow water the depth increases to 20 and 25 feet, the 5 -fathom curve lying about a mile to the south. The oil-pond area is then a sort of terrace, the bottom of which is soft black mud and ooze. At one place on the chart a rocky bottom is marked, but this lies outside the area known as "the pond" and is between the present pond and the site of the old pond. Waves beating upon a terrace laid in material which from its very nature is more or less oily, or contains substances which would act in a manner comparable with that of oil, would seem to present the true explanation of the calmness of the area under discussion.

It may be said in objection to this explanation that these areas of calm water do not appear to be intimately connected with any peculiarity in the topography of the Gulf bottom, or with the character of the material of which it is formed, or with the special abundance or peculiarity in the forms of animal or vegetable organisms living there. On the contrary, precisely the same conditions in all these respects characterize the Gulf coast for many miles, and if they are sufficient to produce calm water at one or two points they should produce the same effect along the entire coast. An essential feature which must be accounted for by any satisfactory explanation is the extremely local character of the quiet spots and their persistence for many years, practically unchanged, although it appears that the location of the western area was permanently shifted some distance to the east during the great storm of 1878 .

Whether or not these areas of calm water are due to the presence of oil must for the present, therefore, remain an open question; but, at any rate, some other explanation than that offered by Dr. Phillips must be found. Although the presence of oil in these so-called oil ponds has not been proved, there is no question of its occurrence in the immediate vicinity. At various points along the west jetty at the mouth of the Sabine River oil globules may be obtained by stirring the mud to a depth of 6 to 10 feet. This locality was examined by Dr. Phillips, and again by his assistants, and he expresses the conclusion in the report above quoted that the oil there found was derived from the Beaumont field; that it had been carried down the Neches River, or Hildebrands Bayou, and had accumulated in the angle between the west jetty and the shore, becoming finally entangled with the mud. The possibility of this origin for the oil at the mouth of the Sabine was thoroughly examined by the writers, and it is not believed possible that it could have been derived from such a source.

Anyone familiar with the behavior of oil upon the surface of water will appreciate the difficulties of the explanation given by Dr. Phillips. Oil tends to spread out in a thin film, in which condition it is subject to rapid evaporation, and is thus quickly dissipated. Moreover, being lighter than water, and having the tendency, owing to its surface ten- 
sion, of spreading in a thin film, it could scarcely sink to the bottom and become entangled in mud to the depth at which it is now found. Again, the oil is found only along the west jetty, whereas, if it had floated down the river it should be found in equal or greater quantities along the east jetty, owing to the direction of the prevailing winds and currents. Finally, while the chief attention has been attracted to it sinee the discovery of the Beaumont field, it is reported on good authority that the oil was observed while the jetties were heing constructed, many years before it could possibly have been derived from Beaumont.

The conclusion appears inevitable, therefore, that the oil is either indigenous in the mud forming the Gulf bottom, or, if derived from any extraneous source, that this source is the underlying beds. It is of course possible that it has been formed in place, through chemical or organic agencies, chiefly by living diatoms, as suggested by Dr. Phillips in the report above quoted. While he does not state his conclusion explicitly, he apparently inclines to the view that while the oil actually found is derived from the Beaumont field, oil of similar character may be secreted by the diatoms living in the mud. In order to determine this point numerous samples of mud were collected at various places in the vicinity, from the surface, at different depths of water, and from a considerable depth below the surface. These were submitted for chemical and microscopical study to Dr. Harold J. Turner, of Johns IIopkins University. Dr. 'Turner's results are here given in full:

EXAMINATION OF MUD FROM GUI,F OF MFXICO.

By H. .т. TинNkк.

"In the plasma" of certain species of diatoms numerous minute globules of oil are contained. They are distributed irregularly through the body. In the genera Navicula and Pleurosigma the globules are relatively large, and in Navicula most numerous. Under the microscope the globules of oil in the body of the diatom strike the eye at once by their great refraction of the light. The fatty nature of the globule is shown by its immediately turning dark upon staining with osmic acid, as was first pointed out by Schultze. ${ }^{b}$ Diatoms are plants, and build up their organic structure under the influence of light from carbon dioxide and water. Starch and sugar are not formed, and it may well be that the oil is the first product of assimilation. Both Lïders ${ }^{c}$ and Pfitzer ${ }^{\prime l}$ have observed that the fatty oil is

\footnotetext{
a E. Pfitzer. Bau und Entwicklung der Bacillariaceen, in J. Hanstein'ł Botanische Abhand lung, 1871, p. 33.

b Schultze, Bewegung der Diatomen, p. $3 i 4$

$c$ Lüders, Beobachtung, u. s. w., p. 42.

$d$ Pftzer, Hanstein's Botanische A hhandlung, p. 34 .
} 
accumulated especially at the time when the cells are existing under unfavorable conditions, as when they are contained in a basin of water in a room. When the water in the basin is renewed, and consequently the oxygen also, the oil is largely reabsorbed in the plasma of the diatom.

"In a recent investigation Kraemer and Spilker" have suggested that in the oil of diatoms petroleum may have its origin. 'They worked upon some material to which the name 'Seeschilck' (sea slime, ooze) has been applied. The material oceurs in Uckermark, a subdivision of Prussia, north of Berlin. It underlies a peat bog and reaches the depth of more than 40 feet. To the hand it has a somewhat fatty feel. The mass contains 90 per cent water, which dries out slowly in the air. The material is rich in nitrogen, containing more than 3 per cent; and it is used both for fertilizing purposes and for the extraction of ammonia on a large scale. Under the microscope the ooze is seen to consist principally of diatoms, such, for example, as species of Navicula, Melosira, and Pleurosigma. Upon extracting the dried mass with hot benzine and erystallizing the material obtained from alcohol, a crystalline product melting at $75^{\circ} \mathrm{C}$. is obtained. The residue, insoluble in alcohol, closely resembles paraffin oil obtained from certain petroleums.

"By treating the ooze with 5 per cent hydrochloric acid (by which operation about one-half of the weight is lost as hydrocarbons, organic acids, etc.) and drying the insoluble portion, there was obtained on the average 3.6 per cent of diatom wax which could hardly be distinguished from ozocerite. It had a black color, a fatty luster, an asphalt fracture, melted between $50^{\circ}$ and $70^{\circ} \mathrm{C}$, and contained 0.97 per cent sulphur. Upon combustion it yielded 73.5 per cent carbon, 11.2 per cent hydrogen, and some oxygen. By investigating various specimens of ozocerite Kraemer and Spilker found that the diatom wax had closely similar properties and they argue a common origin of the two. They suggest that the diatom is an agency in the formation of petroleum. The minute oil globules contained in the plasma of the diatom may be the origin of some petroleum.

"The region where is found the mud yielding the oil is on the margin of the Gulf of Mexico near Sabine Pass, immediately west of the west jetty and about 3,200 feet from its landward end, at the point marked ' $\mathrm{F}$ ' on the accompanying map. 'The mud is thick and black. It appears to be composed of thoroughly macerated organic matter mixed with grains of silica. The shells form only a very small part of the whole. By stirring the mud to a depth of 3 to 4 feet abundant globules of oil, 1 to $4 \mathrm{~mm}$. in diameter, rise to the surface and there break. It appears that the number of globules increases as the depth of the mud which is stirred becomes greater. The strata of mud 
upon which rests the mat upon which the jetty is constructed yield the most oil. The oil is not equally distributed, but is more abundant at some points than at others, being most abundant at the edge of the mat. It is reported that the workmen observed oil in the mud at the time the jetty was constructed.

"A sample of 2 ec. of this oil was collected under great difficulties, as the globules break on reaching the surface of the water. From it the oil was extracted with ether. Upon evaporation of the ether a thick black oil was obtained, possessing not a disagreeable odor, and much thicker than crude Beaumont oil. An attempt was made to compare it with Beaumont oil by violently shaking a sample of the latter with mud and sea water at intervals for three days, distilling with steam for two hours, and extracting with ether. The residual oil still possessed its characteristic odor, though not so marked, and it was not as thick as the oil collected from the mud. It did not seem possible to identify other oil from the mud with the Beaumont oil.

"The various samples of mud were carefully examined for oil. Each sample was repeatedly extracted with redistilled ether. The extracts, after evaporation of the ether, yielded a very thin film of a greenish-yellow residue containing sulphur. A blank determination showed that the method was capable of extracting a globule of oil about $3 \mathrm{~mm}$. in diameter after it had been thoroughly worked into the mud. Two samples, Nos. 109 and 114, yielded trace of oil. The other samples were free of oil. The presence of sulphur is not unusual in darkcolored muds, arising as it does from the decomposition of organic material.

"The salt-water diatoms multiply very rapidly, and their shells would in time fill up the tropical seas were in not for their enemies, which devour them in enormous numbers. The region in the Gulf of Mexico, whence were obtained the samples of muds, is not especially favorable for the accumulation of diatoms, judging from the number of diatoms actually found in the mud. Many species of diatoms belonging to the various genera, namely Navicula, Pleurosigma, Rhoicosigma, Mellosira, and Coscinodiscus, were found in the samples. The species of Navicula and Pleurosigma are the most numerous. Of the entire mass only a very small fraction consists of diatom shells. The mud consists largely of thoroughly macerated organic material mixed with grains of silica. A 10 per cent hydrochloric acid produced just a slight effervescence.

"The microscopical and chemical examination of the samples of mud gave the following results:

No. 105. Collected 6 feet below the surface, which was covered by $t$ feet of water at mean tide, on beach, at point marked "A" on map. Few whole diatom shells; no living diatoms; no oil.

No. 106. Collected 30 feet below surface at same place as No. 105. Few pieces of broken shells. No living diatoms; no oil. 
No. 10\%. Collected 18 feet below surface and 17! feet below tide level, on beach, at "B." Sume as No. 106 .

No. 108. Collected 30 feet below surface, at same place as No. 107. Same as No. 107.

No. 109. Collected from surface, uncovered at low tide, west of west jetty, Sabine Pass, about 600 feet from landward end, at "C." This sample consists of two kinds of mud, one black, the other greenish-yellow in color. In the dark-colored mud the shells were numerous. The greenish-yellow mud was plentifully supplied with diatom shells and contained living diatoms of the species Navicula and Pleurosigma. The entire sample of 115 grams yielded a trace of oil. The sample was from mud showing oily film on surface.

No. 110. Collected 5 feet below surface, in same place as No. 109. Many shells; no living diatoms; no oil.

No. 111. Collected 6.8 feet below surface, exposed at extremely low tide, 200 feet west of west jetty, 3,500 feet from its landward end, at "D." Few shells: no diatoms; no oil.

No.112. Collected 6 feet below surface, which is covered at mean low tide, 300 feet west of west jetty, 5,500 feet from its landward end, at "E." Same as No. 111.

No. 114. Collected 4 feet below surface, covered by 2 feat of water, at mean low tide, west of west jetty, 3,200 feet from its landward end, at "F." Shells no more numerous than in No. 111. 100 grams of mud yielded a trace of oil.

No. 115. Collected 10 feet below the surface, which is covered by a few inches of water at low tide, 250 feet east of east jetty, 50 feet from edge of marsh, at "G." Few whole shells; no living diatoms; no oil.

No. 116. Collected at surface, same place as No. 115. Few shells; living diatoms - present; no oil.

No. 11\%. Collected 2 feet below surface covered by $9 \frac{1}{2}$ feet of water, 6,000 feet west of west jetty, at "H." No living diatoms; some shells; no oil.

"Diatom shells are found in all the samples, but they are not abundant in a single one. They are, however, more abundant in samples Nos. 109 and 116 than in any of the others. Beth of these samples were collected from the surface of the mud, while all the others were collected from below it. In each of the samples collected from 2 to 8 feet below the surface, i. e., Nos. 111, 112, 114, 115, and 117, a few shells are found. The shells are least abundant in samples Nos. 106, 107 , and 108, which were collected from 18 to 30 feet below the surface along the shore.

"Living diatoms were found in the two samples taken at the surface, Nos. 109 and 116, but they were absent from all the samples which had been collected below the surface of the mud. The compact nature of the mud, which prevents free circulation of water and consequent renewal of the oxygen, is inimical to the existence of the diatoms.

" The samples of mud were free of oil, except samples Nos. 109 and 114. The latter is the mud from which the oil globules rise when stirred, and the occurrence of the oil in No. 109 is doubtless to be attributed to the same cause as will account for that in No. 114. The 
samples of mud which were collected 2 and 9 feet below the surface were free of living diatoms. The quantity of shells contained in the mud was small in comparison with the total contents of the mud.

"With these facts before us it does not seem possible to explain the occurrence of the oil in the black mud as arising from the action of diatoms. It can not be attributed to the segregation of oil by living diatoms, because of their entire absence from the mud; nor can it have its origin in diatoms buried in the mud in the past, because of the small number of shells present; and, lastly, as regards its contents of diatoms, the mud from which the oil rises is not different from the mud at various places near by, which show no traces of oil."

The results of this investigation by Dr. Turner, while not absolutely conclusive, indicate that some other source for this oil must be sought than the diatoms. Since, as shown above, it is entirely improbable that the oil was derived from Beaumont by floating upon the surface of the water, the only other source assignable is from the underlying strata. - It does not necessarily follow, even if this is the case, that this region is underlain by a commercial deposit of petroleum, but the indications are sufficiently favorable to warrant thorough exploration by means of the drill. The most favorable indications are afforded within the region lying between the quarantine station and the outer end of the west jetty and thence westward for a quarter of a mile.

It is a fact which may be worthy of note that this locality is intersected by a straight line passing through the Vinton and Sulphur districts in Louisiana, both of which, as will be described later, show favorable indications of oil. The relations of these several localities are shown on the map, Pl. VII (p. 144).

SEA WAX.

In connection with the so-called oil ponds may be mentioned a peculial substance called sea wax, which is frequently found along the Gulf beach from the Sabine to Corpus Christi. This sea wax is reported to have been found in cakes as large as 6 or 8 feet in length and an inch or two in thickness. The chemical composition of this material has been determined by Dr. A. I. Watz, of Tulane University, his results being given in full by Dr. Phillips in the report above cited. This sea wax is undoubtedly a petroleum residuum or an asphaltum. The cakes have traces of concentric structure, as though the material had spread out in all directions from the source of supply at the center, where it is slightly thicker than elsewhere. The source of this material is not known, and it may have nothing whatever to do with the oil ponds, but its presence is at least suggestive and points to the existence of springs of liquid bitumen somewhere in the Gulf, and to that extent supports the theory that the oil ponds are actually 
due to the escape at these points of petroleum from the underlying beds.

WELL RECORDS.

Some prospecting has been done in this district, but thus far no producing territory has been developed, although traces of oil have been found. All the wells thus far drilled have been relatively shallow, and they have not exhausted the possibilities even in their immediate vicinity. Owing to the southeastward dip of the Coastal Plain formations the oil-bearing horizons must be sought at considerably greater depth in this district than at Beaumont.

Two wells have been drilled on Hildebrands Bayou, on the Grange league, one at Nederland, one at Port Arthur, and three at Sabine Pass, all of which have been abandoned. The sections shown by these wells are more uniform than is usually the case in the Coastal Plain formations. The following may be taken as typical:

Log of Port Arthm. Oil ('ompany's well, : $\frac{1}{2}$ miles west of Port Arthur.

[Elevation, about 25 feet.]

\begin{tabular}{|c|c|c|c|c|}
\hline & Character of strata. & Thickness. & From-. & To- \\
\hline & & Feet. & Feet. & Feet. \\
\hline 1 & Blue surface clay . . . & $8 \pi$ & 0 & $8 \gamma$ \\
\hline 2 & Wet blue sand $\ldots \ldots$ & 22 & 87 & 109 \\
\hline 3 & Dry white sand $\ldots \ldots \ldots$ & 182 & 109 & 291 \\
\hline 4 & Blue clay . . . . . . . . & 40 & 291 & 331 \\
\hline 5 & Dry sand . . . . . . . & 70 & 331 & 401 \\
\hline 6 & Blue clay $\ldots \ldots \ldots \ldots$ & 40 & 401 & 441 \\
\hline 7 & Whitish-yellow wet sand & 25 & 441 & 466 \\
\hline 8 & Dry sand . . . . . . & 30 & 466 & 496 \\
\hline 9 & Hard blue clay . . . . . . & $22 \pi$ & 496 & 723 \\
\hline 10 & Sand with a little oil... & $1 \frac{1}{2}$ & 723 & $724 \frac{1}{2}$ \\
\hline 11 & Hard blue clay . . . . . & $5: 3 \frac{9}{4}$ & $724 \frac{1}{2}$ & 778 \\
\hline 12 & Bluish wet sand . . & 148 & $\tau \% 8$ & 926 \\
\hline 13 & Blue clay $\ldots \ldots \ldots$ & $4 \overline{3}$ & 926 & $9 \tau 1$ \\
\hline 14 & Wet sand ...... & 30 & $9 \pi 1$ & 1,001 \\
\hline 15 & Sand and clay . . . . . . . . & 119 & 1,001 & 1,120 \\
\hline 16 & Conglomerate of sand, mud, and clay . . . . & 140 & 1,120 & 1,260 \\
\hline
\end{tabular}

At Sabine Pass four wells have been drilled within a radius of 5 miles. In general the section shown by these wells consists of alternate beds of blue clay and sand, the heavy blue clays predominating. Three were drilled in prospecting for petroleum and the fourth for the purpose of supplying water to the hotel at Sabine Pass. The following section may be taken as typical of the four: 
Log of Texas Oil Company's well on the B. F. Howard league, Jefferson County, Tex., 3 miles west of Sabine Pass.

[Elevation, about 15 feet.]

\begin{tabular}{|c|c|c|c|c|}
\hline & Character of strate. & Thickness. & From- & To- \\
\hline 1 & Blue and yellow clay .... & $\begin{array}{l}\text { Feet. } \\
\qquad 170\end{array}$ & $\begin{array}{l}\text { Feet. } \\
\\
\end{array}$ & $\begin{array}{l}\text { Feet. } \\
\qquad 170\end{array}$ \\
\hline 2 & Dark quicksand & 130 & 170 & 300 \\
\hline 3 & .............. & 430 & 300 & 730 \\
\hline 4 & y with asphalt $\ldots$ & 33 & 730 & 763 \\
\hline 5 & Blue and yellow clay with oil at bottom. & 236 & 763 & 999 \\
\hline 6 & Säd & 2 & 999 & 1,001 \\
\hline 7 & Blne clay & 38 & 1,001 & 1,039 \\
\hline 8 & Bluish-black sand & 17 & 1,039 & 1,056 \\
\hline 9 & Blue clay .. & 2 & 1,056 & 1,058 \\
\hline 10 & Coarse white sand . . & 77 & 1,058 & 1,135 \\
\hline 11 & Blue clay and sand ...... & 155 & 1,135 & 1,390 \\
\hline 12 & Sand, clay, and shells . . . . . . & 96 & 1,390 & 1,486 \\
\hline
\end{tabular}

Petroleum in small quantities showed in the sand No. 12, and it is claimed there was enough gas to lift the casing a few inches. The sand was very fine and flowed easily. It filled the well casing in a few hours to a height of 300 feet.

In the German-American Oil Company's well the sand No. 12 of above section was underlain by yellow clay and gravel to a depth of 60 feet. In the Coast Ridge well wood was found in the sand No. 10 at a depth of 1,120 feet. The hotel well gave abundance of salt water at 1,061 feet.

The limestone and sandstones so prevalent in the upper portion of the section in the Beaumont district do not appear in any of these wells. It may be inferred from this either that the sandstones have a dip sufficiently steep to carry them below the bottom of these wells, or that they thin out toward the southeast and are replaced by unconsolidated sands. The differences in the sections at Beaumont and Sabine are probably due to both of these causes.

\section{SOUR LAKE DISTRICT.}

\section{LOCATION AND HISTORY.}

This district is located in Hardin County, about 8 miles north of the Southern Pacific Railroad station Sour Lake, and about 20 miles a little north of west from Beaumont. The occurrence of oil and asphalt in this district has been known since the earliest settlement of the country. The first published account is in Wall's work on the asphalt deposits of Trinidad. At several points the surface of the ground is covered with asphaltum, evidently a residuum from petroleum, which in small quantities still reaches the surface. Considerable quantities of inflammable gas also reach the surface along with the oil and with the sulphur water which supplies the lake.

Bull. 212-03-8 
Practically nothing was done looking to the development of this district until 18:13, when the prospecting for oil then in progress at Benumont induced several parties to prospect this field, without, however, discovering any commercial deposits of oil. In 1895 the Savage Brothers drilled several small wells which gave so much promise that in the following year W. B. Sharp put down a well for the Trinity Lubricating Company, of Dallas. This company also commenced the erection of a sinall refinery, but the well not producing sufficient oil and there being no prospect of purchasing any from other sources, the work was abandoned.

In 1898 a Galveston company, known as the Gulf Coast Refining Company, with a capital of $\$ 25,000$, was formed for the purpose if

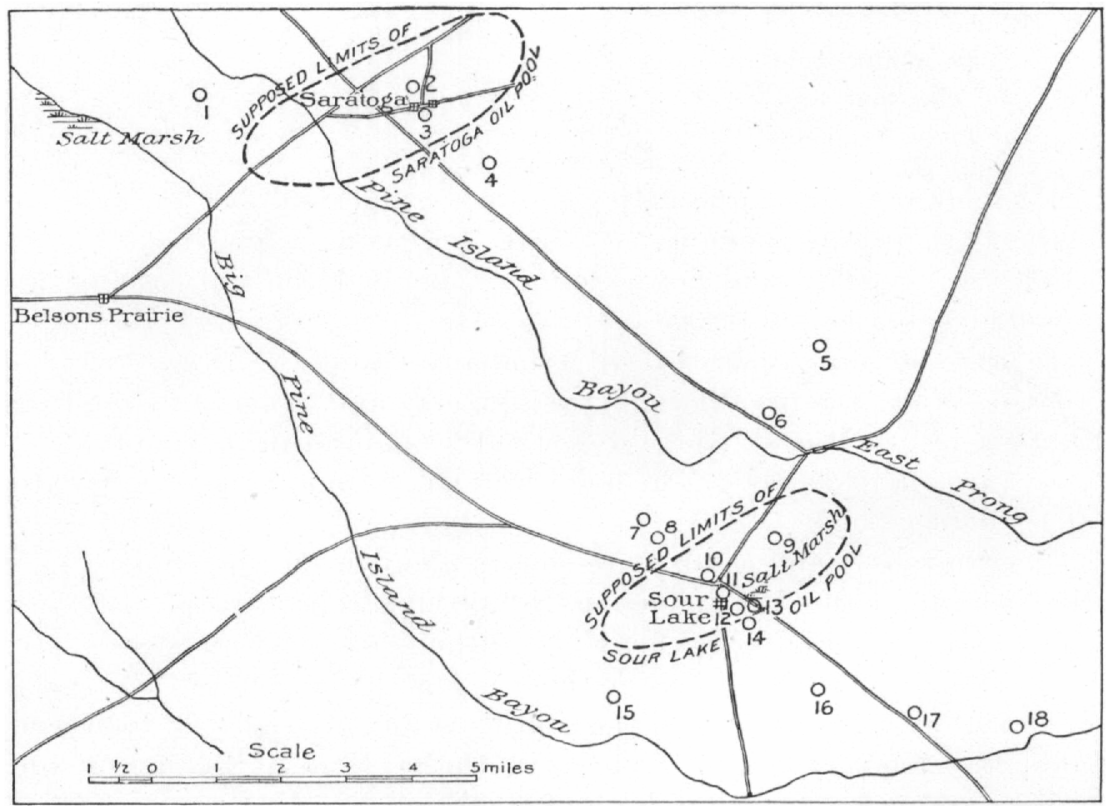

FIG. 5.-Index map showing location of Sour Lake and Saratoga oil pools.

operating in the Sour Lake district. A refinery having a daily capacity of 100 barrels was erected and a contract entered into with the Savage Brothers by which they were to supply the crude petroleum at the rate of not less than 100 barrels daily. A 2-inch pipe line a half mile in length was laid to connect the wells with the refinery. It was the intention of the company to manufacture lubricating oil only. After about 500 barrels of crude oil had been produced and shipped in that condition, chiefly for experimental work, the Savage Brothers defanlted in their contract and the works of the company, including a completed refinery, were abandoned. The Savage and Sharp wells were drilled only to a depth of about 250 feet, and, although they yielded sminll quantities of petroleum, were not considered successful or sufficiently promising to warrant further pros- 
pecting. With the discovery of the Beaumont oil pool in 1901 there was renewed activity in prospecting in the Sour Lake district. Ten companies have put down wells in this district, of which three have been successful in obtaining petroleum in commercial quantities. The Sour Lake district, as shown on the map (fig. 5), includes an oval area measuring abont 6 miles in length and 4 to 5 miles in width.

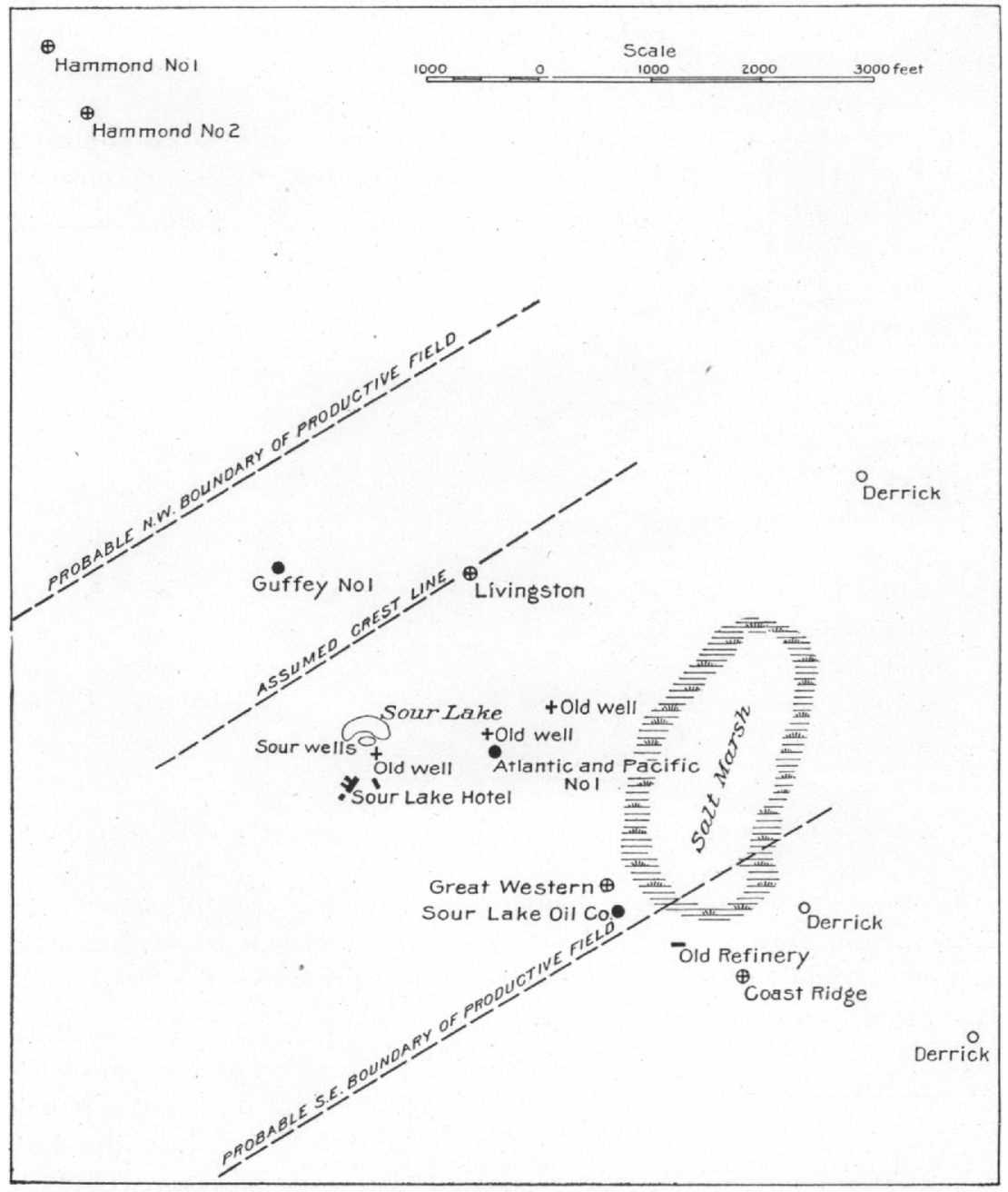

FIG. 6.-Map of Sour Lake district.

The general course of its longer axis is approximately southwest and northeast. This territory has been as yet very imperfectly explored, but from indications afforded by the wells thus far drilled it is altogether probable that the productive territory will be greatly resiricted and found to form a pool similar in form and extent to the Spindletop pool. The limits given on the accompanying map are very largely hypothetical. 
WELL RECORDS.

The first deep well drilled in this field was the Guffey No. 1, located on the Stephen Jackson league, about 2,000 feet north of the hotel and lake. This well was drilled to a depth of 1,400 feet, and yields the following section:

Log of Guffey well No. 1, Sour Lake, Hardin County, Tex.

[Elevation, 90 feet.]

\begin{tabular}{|c|c|c|c|c|}
\hline & Character of strata. & Thickness. & From- & To- \\
\hline & & Feet. & Feet. & Feet. \\
\hline 1 & Yellow sand. & 40 & 0 & 40 \\
\hline 2 & Oil in clay ... & 10 & 40 & 50 \\
\hline 3 & Clay .... & 100 & 50 & 150 \\
\hline 4 & Sand & 125 & 150 & 275 \\
\hline 5 & Shale............. & 4 & 275 & 279 \\
\hline 6 & Oil sand .... & 21 & 279 & 300 \\
\hline$\tau$ & Shale _ & 330 & 300 & 630 \\
\hline 8 & Rock & 35 & 630 & 665 \\
\hline 9 & Rock, shale, and gumbo & 125 & 665 & 790 \\
\hline 10 & Oil sand . . . . & 20 & 790 & 810 \\
\hline 11 & Gumbo $\ldots \ldots$ & 6 & 810 & 816 \\
\hline 12 & 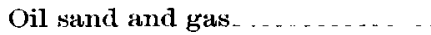 & 6 & 816 & 822 \\
\hline 13 & Sand and gas . . . . . . & 2 & 822 & 824 \\
\hline 14 & Third gas sand .... & 40 & 824 & 864 \\
\hline 15 & Sand and oil & 36 & 864 & 900 \\
\hline
\end{tabular}

The $\log$ is not complete, the well having reached a depth of 1,400 feet.

This well encountered considerable quantities of oil at various horizons, notably at $1,100,1,250$, and 1,400 feet, where drilling was stopped. Small quantities of salt water were also encountered at various levels, and at 822 feet gas was met with in such quantities as to blow out the drill and a large quantity of sand, mud, rock, and water, which seriously delayed the drilling operations. This well has a strong flow of oil from the fine sand at a depth of 1,400 feet.

Twenty-five hundred feet southeast of this well, and close to the location of one of the old Savage wells, the Atlantic and Pacific Oil Company has drilled two wells about 700 feet in depth which have developed a strong flow of oil. Several oil-bearing horizons were found in the drilling, some of which are doubtless of commercial importance.

The following logs of the Atlantic and Pacific well No. 2 and of the Sour Lake Springs Company well No. 1 were supplied by the driller, Mr. N. Sinclair. These logs are interesting and valuable from the 
fact that both have been drilled near the center of this field and almost directly between the Guffey No. 1 and Sour Lake Oil Company's well No. 1.

Condensed log of Atlantic and Pacific well No. 2

[Elevation, 100 feet.]

\begin{tabular}{|c|c|c|c|c|}
\hline & Character of strata. & Thickness. & From- & To- \\
\hline 1 & Mostly sand with gravel and bowlders & $\begin{array}{l}\text { Feet. } \\
\qquad 170\end{array}$ & Feet. & $\begin{array}{l}\text { Feet. } \\
170\end{array}$ \\
\hline 2 & $\begin{array}{l}\text { Hard clay with beds of stones at intervals of } \\
\text { about } 6 \text { feet; some oil in hard strata. }\end{array}$ & 280 & $1 \% 0$ & 450 \\
\hline 3 & Hard clay & 110 & 450 & 560 \\
\hline 4 & $\begin{array}{l}\text { Principally gumbo clay and hard limestone } \\
\text { streaks about } 5 \text { feet thick }\end{array}$ & 40 & 560 & 600 \\
\hline 5 & $\begin{array}{l}\text { Blue clay and gumbo with some hard strata } \\
\text { of lime rocks and some gravel beds. }\end{array}$ & 80 & 600 & 680 \\
\hline 6 & $\begin{array}{l}\text { Streaks of oil sand and streaks of hard clay } \\
\text { between }\end{array}$ & 45 & 680 & 725 \\
\hline
\end{tabular}

Log of the Sour Lake Springs Company's well No. 1.

\begin{tabular}{|c|c|c|c|c|}
\hline & Character of strata. & Thickness. & From- & To- \\
\hline 1 & Coarse sand. & $\begin{array}{l}\text { Feet. } \\
\qquad 90\end{array}$ & Feet. & $\begin{array}{l}\text { Feet. } \\
\quad 90\end{array}$ \\
\hline 2 & Clay and stones. & 50 & 90 & 140 \\
\hline 3 & Sand . . . . & 20 & 140 & 160 \\
\hline 4 & Hard clay, stone beds, and gravel $\ldots \ldots$ & 140 & 160 & 300 \\
\hline $\mathbf{5}$ & $\begin{array}{l}\text { Hard clay, gumbo strata of stones and gravel } \\
\text { with gas and some oil }\end{array}$ & 256 & 300 & 556 \\
\hline 6 & $\begin{array}{l}\text { Hard sandstone with good show of oil and } \\
\text { gas; 8-inch casing on hard streak; oil from } \\
\text { which would produce about } 100 \text { barrels per } \\
\text { day (estimated) }\end{array}$ & 14 & 556 & 570 \\
\hline 7 & Blue clay and gumbo & 44 & $5 \% 0$ & 614 \\
\hline 8 & $\begin{array}{l}\text { Oil sand and conglomerate rock of all kinds } \\
\text { from the above depth. Well flowed out all } \\
\text { the water and commenced flowing oil } \\
\text { through 8-inch pipe, but choked }\end{array}$ & 16 & 614 & 630 \\
\hline 9 & Sand with strong gas flow $\ldots \ldots \ldots \ldots$ & 50 & 630 & 680 \\
\hline
\end{tabular}

This well choked at 630 feet, and although cleaned out and deepened to 680 feet does not now flow.

The Sour Lake Oil Company's well is located about 1,800 feet southeast of the Atlantic and Pacific Company's well. 'This well is 1,500 feet in depth, and during the course of the drilling hot sulphur water was encountered at several levels, the strongest flow being between 900 and 960 feet. At 960 feet an oil-bearing horizon was encountered, and another one was found at 1,460 feet. Rock was drilled through 
between 900 and 1,000 feet and between 1,400 and 1,490 feet, the strata comprising a series of rock beds with seams of clay and bowlders. This well does not flow, but will supply a considerable quantity of oil under the pump.

These are the only wells in the Sour Iake field showing oil in commercial quantities. A number of others have been drilled to depths between 1,000 and 2,000 feet and abandoned. About three-quarters of a mile northwest of the Guffey well the IIammond Oil Company drilled two wells, No. 1 to a depth of 1,860 and the No. 2 to a depth of 1,000 feet. Neither of these wells found oil of any kind and both finished in clay. In the same region, on the Bridges survey, the Empire State Coal, Oil, and Iron Company abandoned its well at 1,284 feet in a blue clay: About 4 miles southeasti of the Sour Lake wells the Byrd syndicate found small seeps of oil at $1,370,1,500$, and 1,620 feet, and developed a strong artesian water flow at 1,900 feet, causing an abandonment of this well. Not more than 1,000 feet south of east from the Sour Lake Oil Company the Coast Ridge Oil Company abandoned its well in a heavy sand at 600 feet, and on the southeast corner of the William Young league the Gold Thread Oil Company has suspended operations in a heavy blue clay at 450 feet.

The Great Western Company is located not more than 300 feet north of the Sour Lake Oil Company's well, and the well has been abandoned at a depth of about 600 feet. In drilling, heavy beds of a gray quicksand were encountered, together with strong flows of hot sulphur water. This water is stated to have a temperature of $100^{\circ} \mathrm{F}$. when issuing from the casing.

\section{GEOLOGIC STRUCTURE.}

The Sour Lake district, as shown on the geologic map, Pl. I, is located on the outcrop of the Village Creek sands. No fossils have been obtained from any of the wells thus far drilled, and it is therefore impossible to make definite statements regarding the geologic horizon of the oil-bearing sands. It appears probable, however, that the principal productive horizon is the same as that at the Spindletop pool, although the character of the beds is different. Not enough drilling has yet been done in this district to determine its limits or its structure except in a very general way. The indications point very strongly to an anticlinal or dome structure, similar to that of the Spindletop pool. The deformation appears to be less abrupt in this case, and it has influenced the surface contours only to a very slight extent. There is, however, a slight elevation of the surface, but the plain is here less perfectly preserved than at Beaumont, and the presence of considerable timbered areas conceals to a large extent the surface elevation.

On the whole the indications may be regarded as fairly favorable 
for the development of a productive pool in this district. Since the oil-bearing beds consist of fine, unconsolidated sand, instead of porous dolomite, as at Spindletop, the free flow of the latter pool need not be expected, but more or less difficulty will be experienced from the choking of the casing by sand. Some device for straining the oil as it enters the casing will doubtless be necessary. The chief unfavorable feature of the district is the abundance of salt water encountered in several of the wells at various depths. Salt water may be expected beneath the oil in all the pools of this Coastal Plain region, and it will probably in every case invade the oil-bearing stratum as the oil is exhausted. Oil need not be looked for, however, in any bed at a lower level than it is found saturated with salt water. If it is found in a well which has previously passed through a salt-water horizon the two must be separated by an impervious stratum. In other words, wherever there is free circulation the oil will always be found above the salt water.

\section{SARATOGA DISTRICT.}

\section{LOCATION AND HISTORY.}

This district is also located in Hardin County, about 12 miles nearly north of Sour Lake. The surface rocks are the Columbia beds, generally soft sands, but containing also indurated sandstones, which outerop in the yicinity of the hotel. This region is generally heavily timbered, and its surface forms a much less perfect plain than that underlain by the Beaumont clays, farther south. Hence if the district contains a dome-like elevation it can not be readily detected. The details of the topography are erosional rather than constructional.

The surface indications are here similar to those at Sour Iake, viz, oil springs giving rise to local accumulations of petroleum residuum or asphalt, and the escape of inflammable gases, associated with sulphur waters.

On the strength of these surface inclications the Savage brothers in 1896 put down a well to a depth of about, 250 feet, and obtained a small flow of oil, associated with water and gas. Although this well was abandoned as unsuccessful after collecting a few barrels of oil, it is still flowing small quantities of oil and water. A short time after this a second well was begum by W. P. Conroy, about half a mile south of the Savage well, at a locality where oil appears at the surface in several shallow holes, associated with sulphur water. After reaching a depth of about 120 feet the tools became stuck, and the well was abandoned.

\section{WELL RECORDS.}

Shortly after the development of the Beaumont field the prospecting in the district was renewed. The Saratoga Oil and Pipe Line Com- 
pany located a well known as the Hooks No. 1 on the J. F. Oliver tract of the Maria Ximenes league-2 on accompanying map, fig. 5, p. 114. This well gives the following section:

Log of Hooks well No. 1, Saratoga, Hardin County, Tex.

[Elevation, 100 feet.]

\begin{tabular}{|c|c|c|c|c|}
\hline & Character of strata. & Thickness. & From-- & To- \\
\hline & & Feet. & Feet. & Feet. \\
\hline 1 & Sand & 78 & 0 & 78 \\
\hline 2 & Sand, oil, and water & 95 & 78 & 173 \\
\hline 3 & Hard blue and white clay & 32 & $1 \% 3$ & 205 \\
\hline 4 & Sand and oil $\ldots \ldots$ & 53 & 205 & 258 \\
\hline 5 & White clay ... & $\tau$ & 258 & 265 \\
\hline 6 & Soft blue clay & 40 & 265 & 305 \\
\hline 7 & Rock $\ldots \ldots$ & 3 & 305 & 308 \\
\hline 8 & Sand or soft rock $\ldots . .$. & 8 & 308 & 316 \\
\hline 9 & Rock, with gas at 325 & 9 & 316 & 325 \\
\hline 10 & Hard rock . ... & 2 & 325 & 327 \\
\hline 11 & Gumbo & 8 & 327 & 335 \\
\hline 12 & Sand rock & 15 & 335 & 350 \\
\hline 13 & Blue clay and shale $\ldots . . . . . . . . .$. & 5 & 350 & 355 \\
\hline 14 & $\begin{array}{l}\text { Sand cement; small streams of oil, first after } \\
325 \text {. Oil shows in all formations to this } \\
\text { depth }\end{array}$ & 23 & 355 & 378 \\
\hline 15 & $\begin{array}{l}\text { Gravel, becoming coarser and changing from } \\
\text { white to black toward bottom, and gumbo }\end{array}$ & 51 & $3 \pi 8$ & 429 \\
\hline 16 & $\begin{array}{l}\text { Mostly gumbo, with small layers of very hard } \\
\text { material, but no oil } \ldots\end{array}$ & 45 & 429 & 474 \\
\hline 17 & Blue clay $\ldots \ldots \ldots$ & 4 & 474 & 478 \\
\hline 18 & $\begin{array}{l}\text { Sandstone, with oil of golden color; rock be- } \\
\text { comes softer and gradually turns to sand }\end{array}$ & 6 & 478 & 484 \\
\hline 19 & Sand; oil flows between 478 and $488 \ldots$ & 4 & 484 & 488 \\
\hline 20 & Sandstone and blue clay in thin layers........ & $4 \mathfrak{2}$ & 488 & 530 \\
\hline 21 & $\begin{array}{l}\text { Blue clay; water from } 475 \text { and oil from } 500 \\
\text { feet, but not in large quantities. No gas } \\
\text { below } 500 \text { feet }\end{array}$ & 15 & 530 & 545 \\
\hline 22 & Hard clay or soft rock . . . . . . . & 12 & 545 & 557 \\
\hline 23 & Hard rock . . . . & 8 & 55 & 565 \\
\hline 24 & Streaks of clay and rock ...... & 78 & 565 & 643 \\
\hline 25 & Very hard rock, with som $\Rightarrow$ oil & 2 & 643 & 645 \\
\hline 26 & Clay .... & $2 \tau$ & 645 & $6 \pi 2$ \\
\hline 27 & Sand rock, with oil $\ldots \ldots$ & 8 & 672 & 680 \\
\hline 28 & Blue clay, with bowlders .... & 101 & 680 & 781 \\
\hline 29 & Lime rock . . . . . & 3 & 781. & 784 \\
\hline 30 & Blue clay -. & 7 & 784 & 791 \\
\hline
\end{tabular}


Log of Hooks well No. 1, Saratoga, Hardin County, Tex.-Continued.

\begin{tabular}{|c|c|c|c|c|}
\hline & Character of strata. & Thickness. & From- & To- \\
\hline 31 & Lime rock, with gas under rock & Feet. & $\begin{array}{l}\text { Feet. } \\
\quad 791\end{array}$ & $\begin{array}{l}\text { Feet. } \\
\quad 794\end{array}$ \\
\hline 32 & Blue clay . . . . . . . & 46 & 794 & 840 \\
\hline 33 & Hard shale with oil. & 30 & 840 & 870 \\
\hline 34 & Hard shale & 22 & 870 & 892 \\
\hline 35 & Shale and bowlders . . . . . . & 8 & 892 & 900 \\
\hline 36 & Clay $\ldots \ldots \ldots$ & 8 & 900 & 908 \\
\hline 37 & Hard rock. ... & 7 & 908 & 915 \\
\hline 38 & Soft blue clay & 5 & 915 & 920 \\
\hline 39 & Hard lime rock $\ldots \ldots \ldots$ & 1 & 920 & 921 \\
\hline 40 & Solid rock . . . . . . . . & $1 \stackrel{2}{\sim}$ & 921 & 933 \\
\hline 41 & Soft blue shale ... & $\tau$ & 933 & 940 \\
\hline 42 & Limestone ............. & 3 & 940 & 943 \\
\hline 43 & Shale and loose rock . . . . & $1 \tau$ & 943 & 960 \\
\hline 44 & Hard rock & 5 & 960 & 965 \\
\hline 45 & Oil, sand, loose rock, and shells & 29 & 965 & 994 \\
\hline 46 & Rock to bottom not penetrated. & & 994 & 995 \\
\hline
\end{tabular}

As will be observed from the above $\log$, this well encountered oilbearing beds at frequent intervals almost from the surface. Some of these undoubtedly contain oil in sufficient quantity to be of commercial importance. The last bed passed through consists of soft sand, with hard rock above and below. A $4 \frac{1}{2}$-inch strainer is used to keep the sand from flowing in and choking the well. When first closed off the gage shows a pressure of 83 pounds, which gradually rises to 127 pounds, where it remains stationary. The flow of oil is intermittent, and is estimated at about 500 barrels daily.

The same company has another well drilling-Hooks No. 2-about half a mile south of well No. 1 and within a short distance of the old Conroy well. In this well, No. 2, the gas pressure is much heavier than in No. 1, and one blowout has already taken place. A fair showing of oil was encountered at a depth of 600 feet, accompanied by much gas.

The Libbie well is located about 3 miles to the west of the two Hooks wells, in the Pine Islands Bayou flats. To a depth of something over 700 feet it has shown no indications of oil.

About $1 \frac{1}{2}$ miles southeast of the Hooks No. 2 is the Texas Geyser well. No $\log$ is obtainable, but it is reported to have reached a depth of 1,700 feet without finding any indications of oil.

The four wells above noted are not sufficient to define the limits of the Saratoga oil pool, and the limits given on the accompanying map 
are largely hypothetical. The limits will, however, probably fall somewhere within those given. Also nothing can be stated regarding the structure of the field, except that in all probability it is similar to that in other parts of this region which are better known.

The indications are that a highly productive pool will be developed, in which the conditions will be very similar to those in the Sour Lake district.

\section{HIGH ISLAND DISTRICT.}

\section{LOCATION AND TOPOGRAPHY.}

This district is located about midway between Sabine Pass and Galveston, on the Gulf shore. The so-called island is a small elevated area entirely surrounded by the coast marsh. As shown on the accompanying map (fig. 7), its outline is nearly circular except for an embayment on its southern margin. It is about $1 \frac{1}{4}$ miles in diameter and contains somewhat over 2,000 acres. The surface of the island is slightly undulating and its highest portion has an elevation of 48 feet above tide. At the base of the rather abrupt slopes around the eastern and northern portions of the island is a belt of firm ground called the "second bench," whose surface is only a few feet above the surrounding marsh.

High Island has for many years been noted as a summer resort, and its mineral waters have considerable local reputation. No fresh water occurs on the island and the supplies for drinking purposes are derived from the rainfall. No fewer than twelve wells, distributed over the island and around its base, were drilled some years ago in an unsuccessful attempt to obtain a supply of fresh water. These wells vary in depth from 120 to 350 feet. The materials encountered consist of clay, sand, and fine gravel, with logs of cypress wood and in one case a few inches of limestone, at 275 feet in well No. 4 . Either rock salt or strong brine was found at the following depths: In No. 4 at 260 feet, in No. 7 at 203 feet, in No. 8 at 142 feet, in No. 9 at 193 feet, in No. 10 at 170 feet, in No. 11 at 193 feet, and in No. 12 at 165 feet. These wells are located in the central and southwestern portions of the island. In the northeastern portion the wells are shallower, and instead of striking brine or salt, found sulphur water, with large quantities of hydrogen-sulphide gas. Sulphur is deposited by the decomposition of escaping gas, sometimes in considerable abundance.

Several of these wells still have a strong artesian flow of salt water with a temperature somewhat above $100^{\circ} \mathrm{F}$.

At various points about the margin of the island are salt springs, which give rise to the trembling marshes. The water contains much calcium carbonate in solution, which is precipitated by evaporation about the spring vents and forms a crust over the surface of low 
mounds, being held together by the coarse marsh grasses. Much inflammable gas escapes with the water of these springs.



FIG. 7.-Sketch contour map of High Island. 
WELI RECORDS.

Oil prospectors were attracted to High Island by the similarity of its surface conditions to those at Spindletop, especially the sulphur and gas springs, and some drilling has already been done.

Four companies owning land or having leases on the island combined their interests and put down a well in common. This is called the Big Four No. 1, located near the Smith mineral springs. When the well had reached a depth of 610 feet, the bit with a section of the drill rod was lost, and the well was abandoned. A new well, Big Four No. 2, was located in the immediate vicinity.

The first well gave the following section:

Log of Big Four well at High Island, Chambers County, Tex.

[Elevation, 40 feet.]

\begin{tabular}{|c|c|c|c|c|}
\hline & Character of strata. & Thickness. & From- & To- \\
\hline 1 & Yellow clay $\ldots \ldots$ & $\begin{array}{l}\text { Feet. } \\
\qquad 20\end{array}$ & Feet. & $\begin{array}{l}\text { Feet. } \\
\quad 20\end{array}$ \\
\hline 2 & Sand. & 20 & 20 & 40 \\
\hline 3 & Blue clay ................... & 60 & 40 & 100 \\
\hline 4 & $\begin{array}{l}\text { Clay, sand, and shells. Fresh water at } 180 \\
\text { feet }\end{array}$ & 80 & 100 & 180 \\
\hline 5 & Conglomerate rock .... & 4 & 180 & 184 \\
\hline 6 & Sulphur and clay .... & 23 & 184 & 207 \\
\hline 7 & Hard siliceous rock & 4 & $20 \%$ & 211 \\
\hline 8 & Quicksand and salt water. & 50 & 211 & 261 \\
\hline 9 & Siliceous rock & 5 & 261 & 266 \\
\hline 10 & Brown clay .... & 44 & 266 & 310 \\
\hline 11 & Siliceous rock & 4 & 310 & 314 \\
\hline 12 & Clay ......... & 55 & 314 & 369 \\
\hline 13 & Siliceous rock & 4 & 369 & 373 \\
\hline 14 & Clay ........ & 36 & 373 & 409 \\
\hline 15 & Siliceous rock & 3 & 409 & 412 \\
\hline 16 & Clay & 91 & 412 & 503 \\
\hline 17 & Siliceous rock & 2 & 503 & 505 \\
\hline 18 & Oil sand. & 4 & 505 & 509 \\
\hline
\end{tabular}

Between 509 and 610 feet in depth, where the well was abandoned, is a series of sands and limestones, with much gypsum. The limestone is reported to contain many cavities lined with calcite crystals.

The Big Four well No. 2 at last reports had been drilled to a depth of over 1,000 feet, and after passing the sands and limestones found in Well No. 1, between 500 and 600 feet, continued in limestone or dolomite and gypsum to the bottom. A small quantity of oil was 
found at a depth of 504 feet, but no other indication of oil to the depth thus far reached.

The J. M. Guffey Petroleum Company is drilling four wells on High Island, and the Bolivar and High Island Oil Company has a derrick erected, but has as yet (June, 1902) done no drilling.

\section{GEOLOGIC STRUCTURE.}

Too little is known regarding the stratigraphy and structure of High Island to make definite statements. It is probable that the first 20 to 30 feet of yellow clay should be correlated with the Beaumont clays, which division may also include a portion of the underlying sands and clays. Below these beds are sands and gravels to a depth of somewhat over 100 feet, which may be the equivalents of the Columbia and Lafayette. These gravels are followed by sands, clays, and salt in the southwestern portion of the island, and by clays with limestone and gypsum in the northeastern portion.

That the underground structure of the island is anticlinal, or domeshaped, may be safely inferred from analogy with other districts in the coastal region. The data at present available are not, however, sufficient to determine the extent of the dome or the direction of its axes.

\section{KISER HILL DISTRICT.}

This district is located immediately west of the Brazos River, near the town of Columbia, and about 12 miles southeast of Damon Mound. Kiser Hill has an elevation of from 25 to 30 feet above the level of the river at Columbia, and from 60 to 65 feet above sea level. The surface is underlain by brown sand or sandy loam, probably for the most part river alluvium. The surface of the hill differs slightly from that of the surrounding region, containing much more clay. The limits of this district are not yet determined, since only a single well has been drilled. 'This is the Equitable Mining Company's well, which has reached a depth of only 600 feet. At a depth of 360 feet a small quantity of petroleum was obtained from a bed of sand. At 600 feet a strong flow of gas was encountered, with sufficient pressure to blow out the drilling tools from the well. Great quantities of water and sand, with a small amount of petroleum, were brought out by the gas. The flow of gas was controlled after much difficulty and cased off. It is the intention to drill this well deeper, and the prospects appear to be favorable for obtaining oil in commercial quantities.

\section{MINOR TEXAS DISTRICTS.}

At several other localities in the Gulf Coastal Plain of Texas prospecting for oil has been carried on to some extent. In some cases the location of the wells was determined by certain supposed surface 
indications, such as the presence of sulphur or salt-water springs, the escape of inflammable gas, or the topographic configuration of the surface. In other cases no such surface indications were present, and the wells were located apparently at random on the prairie.

\section{BIG HILL, JEFFERSON COUNTY.}

Big Hill is located about midway between Beaumont and High Island. It has an elevation containing several thousand acres, rising in a gentle swell above the surrounding level prairie. It has a somewhat irregularly crescentic outline. One well has been drilled on the slope of the hill at its eastern extremity. A detailed log of this well is not available, but it is known that at a depth of 350 feet rock was encountered which continued to a depth of 1,400 feet, where drilling was discontinued. 'This rock, which is remarkably uniform throughout its 1,050 feet, is a light-gray crystalline dolomite. The rock is massive, but contains parallel seams which may represent bedding planes. These have an inclination of about $7^{\circ}$, indicating a decided dip in the beds. Since the angle of dip is obtained from cores, its direction can not be determined, but it is assumed to be toward the east, with the surface slope on which the well is located. The dolomite contains much gypsum, and in places is cavernous. A few small pockets of oil were found, but for the most part the rock removed in the form of cores was entirely free from any stain or other indication of oil.

While it can not be stated definitely from data at present available, it appears probable that this locality is upon a dome similar to those at Spindletop and High Island. A well at Winnie, only a few miles to the west, found no rock whatever to a depth of 1,600 feet.

\section{DAYTON HILL.}

In the vicinity of Dayton, in Liberty County, there is a considerable area having an elevation of 90 to 100 feet above sea level and 25 to 30 feet above the level of the surrounding plain. This is generally known as Dayton Hill. It extends westward from the Trinity about 10 miles and has an approximate width of 6 miles. Considerable quantities of gas occur at various localities throughout this whole district, chiefly in small springs and shallow wells. Up to the present time, however, no oil of commercial importance has been found. Two companies are prospecting in this field. The Taylor-Dayton Company is drilling on the northern side of the district and the J. M. Guffey Petroleum Company has put down one well on the southern side. The Taylor-Dayton well, located a short distance from the town of Dayton, is 1,200 feet in depth. Limestone was encountered at 600 feet, and continued to a depth of 800 feet, where rock salt, was encountered, and the latter continued to the bottom of the well. The Guffey 
well reached a depth of 1,900 feet, but no record of the strata passed through is available.

\section{BARBER HILL.}

About 16 miles to the southwest of the Dayton Hill is another elevated region, known as Barber Hill. This is in Chambers County. Some prospecting is being done at this locality, and apppearances are reported to be favorable, but nothing definite is known regarding it.

\section{DAVIS HILL.}

This is an elevation located about 20 miles north of Dayton. Considerable quantities of sulphur water and inflammable gas are reported as occurring, but no prospecting or drilling has yet been done. The surface formations of this locality are mostly sands and soft sandstones.

\section{BRYAN HEIGHTS.}

Small quantities of petroleum have been found in the district known as Bryan Heights, near Velasco, in Brazoria County, in association with great volumes of gas. This is one of the Texas localities recorded by Peckham in the Tenth Census Report as producing asphaltum, although not in commercial quantities. As a result of recent drilling a very large amount of gas has been encountered. When the gas was first struck its pressure was sufficient to lift the 12-inch casing in the well and destroy the derrick. The gas is largely hydrogen sulphide, and flowed at the rate of about $6,000,000$ cubic feet daily. Attempts to shut it off failed and the well was abandoned. A new well is now being drilled near by.

\section{BIG HILL, MATAGORDA COUNTY.}

Another locality of a similar nature occurs at Big Hill, in Matagorda County, about 10 miles east of Bay City. Small quantities of petroleum have been found, and at a depth of 900 feet the gas became unmanageable and blew ont the well tools. This well has been abandoned and a new one commenced. The well flows about 5,000,000 cubic feet of gas, chiefly hydrogen sulphide, daily. No attempts are being made to utilize the gas from either of these wells.

\section{JENNINGS DISTRICT.}

\section{LOCATION AND DEVELOPMENT.}

This district, fig. 8, is confined chiefly to the narrow strip of country lying between the Bayou Nezpique and the Bayou de Cannes, in Acadia Parish, La., and while probably not more than a mile in width, 
extends in a southwest-northeast direction for a aistance of about 3 miles. The Jennings Oil Company's well No. 1 is located in sec. 46, T. 2 W., R. 9 S., and most of the drilling has been confined to that and the adjoining section 47 . Wells are in course of drilling toward the southwest along the supposed line of the anticline in secs. 42 and 63 in the same township and range, No. 63 being a watered section of the older French method of surveys. Another well, that of the Home Oil and Development Company, has been drilled in sec. 44, T. $3 \mathrm{~W}$., R. 9 S., about a mile and a half east of Jennings. Some oil has been reported from this well, but whether in commercial quantities has not been determined. In sec. 1, 'T. 3 W., R. 10 S., the Union Oil and Development Company has commencel to drill, and the Southern Oil Company's wells Nos. 1 and 2 are located in the lower grounds, near the confluence of the two bayous, in secs. 33 and 34, T. 2 W., R. 9 S. Wells Nos. 3 and 4 of this company are located near the Jennings No. 1.

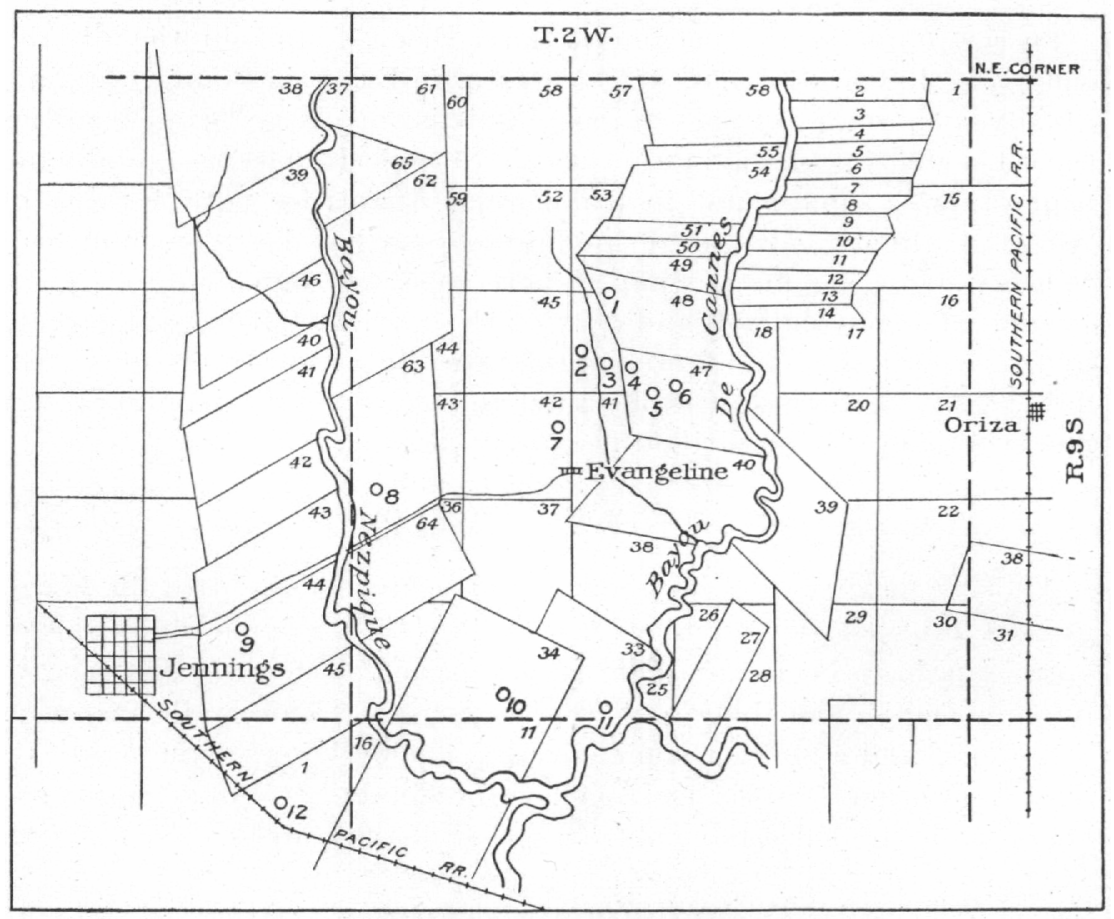

FIG. 8.-Map of Jennings oil field. For list of wells see top of p. 130.

Although no logs of these wells have thus far been obtained with any degree of definiteness, the statements made by Mr. Heywood, of the Jennings-Heywood syndicate, one of the earliest drillers in this field, appear to show that the Jennings field is also situated upon the crest, or nearly so, of a deeply buried anticline. 




INDEX MAP, SHOWING LOCATION OF LOUISIANA OIL DISTRICTS. 

OIL SAND,

The oil-bearing bed in this district is an unconsolidated coarsegrained sand. It lies at a depth of 1,800 feet in the Jennings No. 1 and 1,635 in the Southern No. 1 . In the Southern No. 3 the sand is found at 1,850 feet, and in the same company's well No. 4 it occurs at 1,840 feet. In the Prairie Mamou well, half a mile to the southeast of the Jennings No. 1, a bed supposed to be the oil-bearing sand appears at a depth of 2,200 feet. In the Southern No. 2 an oil sand was found at a little over 2,000 feet. This, from the location of the well, is in all probability the same bed as found in the Prairie Mamou well. The thickness of the oil-bearing sand is not known, but it is at least 50 feet, since it has been penetrated to that depth in the Jennings No. 1. No well has as yet passed entirely throngh to the underlying beds. In the Jennings No. 1, Home Oil and Development Company's well, and in the Southern Company's wells Nos. 2, 3, and 4, the sand has proved to be oil bearing, but in the Prairie Mamou it is dry. The Pelican well No. 1 , in sec. 63 , T. 2 S., R. 9 W., is also dry, and these two wells have been abandoned. The Crowley Oil Company is drilling a well in close proximity to the Prairie Mamou, and claims to have reached a depth of 1,700 feet. The Home Oil and Development Company's well is over 1,700 feet in depth.

Considerable quantities of petroleum have been found in the Southern Oil Company's wells Nos. 3 and 4. The same company's well No. 2 supplies a fair pumping quantity, and the Jennings No. 1 flows somewhat spasmodically. These, with the small quantity already mentioned from the Home Company's well, are the only producing wells in the field at the present time (June, 1902).

More or less gas accompanies these oils, but this has no such pressure as that found at Spindletop or at several other places in the Texas field. A considerable flow of gas occurred in the Pelican No. 2 , but this is the only strong flow recorded.

These wells are about the same in size as those at $\mathbf{S p i n d l e t o p . ~ T h e ~}$ Jennings No. 1 is a 4-inch well, and the Southern No. 3 has been brought in as a 6 -inch well.

Arrangements are being made to bring this oil into market, and already a 6 -inch pipe line is being laid from the field to connect with the Southern Pacific Railroad at Jennings. Some efforts are being made to utilize the bayous Nezpique and de Cannes for barge purposes.

In some respects the petroleum produced in this field is of a better grade than the Spindletop oil. It is much freer from sulphur and will offer less difficulties in refining, although the proportion of illuminants will not be greater than either the Beaumont or Sour Lake oils.

Bull. 212-03-9 


\section{WELLS IN THE JENNINGS DISTRICT.}

List of wells in Jennings district, June, 1902.

[For locations see corresponding numbers on map, flg. 8.]

1. Gusher Oil Co.

2. Southern Oil Co. No. 3.

3. Jennings No. 1.

4. Jennings No. 2.

5. Prairie Mamou Oil Co.

6. Crowley Oil Co.
7. Jennings No. 3.

8. Pelican Oil Co.

9. Home Oil Co.

10. Southern Oil Co. No. 1.

11. Southern Oil Co. No. 2.

12. Union Oil and Development Co.

\section{ANSE LA BUTTE DISTRICT.}

The next most important of the Louisiana petroleum districts is that at Anse la Butte, about 40 miles east of Jennings, on Bayou Vermilion in St. Martins Parish, about 8 miles north of Lafayette.

Three wells have already been drilled in this district, passing through clays, sands, and gravels, with some beds of limestones of varying thickness. In the Pioneer well, of which the record has already been given (p. 63), the first rock found occurred at 174 feet. Limestone is found in the Lucas well between 100 and 108 feet, and in the Anse la Butte well No. 2 rock appears between 225 and 226 feet.

This is the locality described by Harris as near Breaux Bridge, in referring to the occurrence of natural gas in Louisiana. ${ }^{a}$

The section of the Lucas well is as follows:

Log of Lucas well at Anse la Butte, St. Martins Parish, La.

[Elevation, 50 feet.]

\begin{tabular}{|c|c|c|c|c|}
\hline & Character of strata. & Thickness. & From- & To- \\
\hline 1 & Gravel and sand $\ldots$ & $\begin{array}{l}\text { Feet. } \\
\qquad 100\end{array}$ & Feet. & $\begin{array}{l}\text { Feet. } \\
100\end{array}$ \\
\hline 2 & Stratified lime rock $\ldots . . . .$. & 8 & 100 & 108 \\
\hline 3 & $\begin{array}{l}\text { Oil-bearing clay with bands of gravel, sand, } \\
\text { and lignite }\end{array}$ & 140 & 108 & 248 \\
\hline 4 & Soft lime rock . & 4 & 248 & 252 \\
\hline 5 & Oil-bearing clay mixed with gravel. . . & 32 & 252 & 284 \\
\hline 6 & Salt water (rock salt doubtful) . & 8 & 284 & 292 \\
\hline 7 & Oil-bearing clay with gravel & 64 & 292 & 356 \\
\hline 8 & Gravel with water and oil & 11 & 356 & 367 \\
\hline 9 & Hard green clay .......... & 38 & 367 & 400 \\
\hline 10 & Water-bearing sand, no oil. . & 88 & 400 & 488 \\
\hline 11 & Hard green clay - - & 22 & 488 & 510 \\
\hline 12 & Sand and muck ......... & 13 & 510 & 523 \\
\hline
\end{tabular}


Small quantities of hydrocarbon gas reach the surface at numerous points in the neighborhood, but these do not appear to have much commercial value. They appear from the well records to be simply shallow pockets, probably derived from the decomposing vegetable matter in the surface clays or immediately underlying sands.

Small quantities of petroleum are found at various depths in all of these wells, generally associated with sand and gravel. In the Pioneer well the oil was found at depths of 439 and 650 feet associated with rock. At 285 feet and at 1,260 feet the oil-bearing beds were sands and gravels. In the Lucas well the petroleum occurs in clays, gravels, and sands between 108 and 248 feet. The second occurrence was between 252 and 284 feet, the third between 292 and 356 feet, while between 356 and 367 . feet oil occurred accompanied with a strong artesian flow of water. The Anse la Butte Oil and Mineral Company's well No. 2 was drilled to a depth of 801 feet, finishing in a bed of sand and gravel. In this well oil-bearing sands are found between 226 and 228 feet, and again between 265 and 268 feet.

Salt water and salt are generally found accompanying these oilbearing beds. In the Pioneer well a strong flow of salt water accompanied the oil found at 1,260 feet, and in the Tucas well salt water was present between 284 and 292 feet, and between 356 and 367 feet the oil was accompanied with a strong flow of water.

In the Anse la Butte well 179 feet of rock salt is reported between 391 and 570 feet, and between 578 and 790 feet the drill passed through 212 feet of salt.

None of the wells in this district has as yet produced oil or gas for market. There appears to be a large amount of oil in the underlying beds at several horizons, but no pool has yet been found where it has accumulated in sufficient quantity to be of commercial importance. It is probable, however, that further prospecting may reveal the presence of such a pool.

\section{HACKBERRY ISLAND.}

This so-called island, like High Island in Texas, is an elevated area entirely surrounded by coast marsh. It is located in Cameron Parish, 33 miles southwest of Lake Charles, on the south side of Black Bayou, between Black Lake and Calcasieu Iake. It has an area of about 8,000 acres and reaches an elevation of 35 feet. The surface of the island is composed of yellow and black loam. During dry seasons the soil becomes hard and cracks to a considerable depth, like the "hog-wallow clays" of the prairie regions. Gas occurs in all the numerous shallow wells on the island, and the water in several springs is somewhat sulphurous.

Only one well is being drilled in this region and it shows a section made up of sands, clays, and gravels to a depth of 908 feet, followed by limestones, sandstones, and clays. 
Log of the Louisiana and Texas Oil Company's well at Hackberry Island, Louisiana.

[Elevation, 35 feet.]

\begin{tabular}{|c|c|c|c|c|c|c|c|}
\hline & Character of strata. & Thicknes & & From- & & To- & \\
\hline & & & & Ft. $\quad i$ & & Ft. i & in. \\
\hline 1 & Clay, sand, and gravel. & 138 & & 0 & 0 & 138 & 10 \\
\hline 2 & Blue clay . . . . & 156 & 4 & 138 & 10 & 295 & 2 \\
\hline 3 & Sand $\ldots \ldots$ & 45 & 6 & 295 & 2 & 340 & 8 \\
\hline 4 & Clay & 6 & & 340 & 8 & 346 & 8 \\
\hline 5 & Packed sand & 24 & 1 & 346 & 8 & 370 & 9 \\
\hline 6 & Soft blue clay & 40 & 9 & 370 & 9 & 411 & 6 \\
\hline 7 & Sand $\ldots$ & 127 & 7 & 411 & 6 & 539 & 1 \\
\hline 8 & Blue clay - . . & 20 & & 539 & 1 & 539 & 1 \\
\hline 9 & Coarse sand . . . . . & 36 & 5 & 559 & 1 & 595 & 6 \\
\hline 10 & Blue clay with fine sand & 283 & 4 & 595 & 6 & 878 & 10 \\
\hline 11 & Coarse sand and gravel & 30 & & 878 & 10 & 908 & 10 \\
\hline 12 & Hard lime rock and shells & 5 & 2 & 908 & 10 & 914 & \\
\hline 13 & Tough blue clay and lignite & 207 & 5 & 914 & & 1,121 & $\mathbf{5}$ \\
\hline 14 & Lime rock & & 6 & 1,121 & 5 & 1,121 & 11 \\
\hline 15 & Blue clay & 31 & 3 & 1,121 & 11 & 1,153 & 2 \\
\hline 16 & Rock & 1 & & 1,153 & 2 & 1,154 & 2 \\
\hline 17 & Blue clay . . & 101 & 6 & 1,154 & 2 & 1,255 & 8 \\
\hline 18 & $\ldots d o$ & 36 & 11 & 1,255 & 8 & 1,292 & 7 \\
\hline 19 & Sandy clays & 51 & 11 & 1,292 & 7 & 1,344 & 6 \\
\hline 20 & Rock . - & & 6 & 1,344 & 6 & 1,345 & \\
\hline 21 & Sand . . . . . & 11 & 9 & 1,345 & & 1,356 & 9 \\
\hline 22 & Soft rock & 5 & & 1,356 & 9 & 1,361 & 9 \\
\hline 23 & $\begin{array}{l}\text { Alternate layers of sand, clay, and rock, } \\
\text { with hard blue limestone coated with } \\
\text { yellow crystals, changing to sandstone } \\
\text { with pyrites }\end{array}$ & 35 & 8 & 1,361 & 9 & 1,397 & $\mathbf{5}$ \\
\hline 24 & Sand ..... & 9 & 7 & 1,397 & 5 & 1,407 & \\
\hline 25 & Hard rock . & 0 & 8 & 1,407 & & 1,407 & 8 \\
\hline 26 & Sand ... & 13 & & 1,407 & 8 & 1,420 & 8 \\
\hline 27 & Rock & 1 & 1 & 1,420 & 8 & 1,421 & 9 \\
\hline 28 & Clay & 19 & 3 & 1,421 & 9 & 1,441 & \\
\hline 29 & Lignite & 7 & & 1,441 & & 1,448 & \\
\hline 30 & Rock . - - & 3 & 7 & 1,448 & & 1,451 & 7 \\
\hline 31 & Clay ... & 3 & 5 & 1,451 & 7 & 1,455 & \\
\hline 32 & Rock . & 2 & & 1,455 & & 1,457 & \\
\hline
\end{tabular}


A small quantity of oil is reported from this well at a depth of 1,460 feet. Gas was found at several depths, but no record was kept of its occurrences. The test can not be regarded as complete until the well has reached a depth of 2,500 feet, unless rock salt or strong brine is found at a shallower depth.

\section{SULPHUR DISTRICT.}

This district was probably the first to be prospected for petroleum in any portion of the Coastal Plain field. The oozing of petroleum and escape of gas from sulphur springs in a small marsh first attracted attention about the year 1868, and the Louisiana Oil Company was formed for the purpose of drilling for oil. A well put down in sec. 29, T. 9 S., R. $10 \mathrm{~W}$., gives the following section:

Log of Louisiana Oil Company's well at Sulphur, La.

Feet.

1. Blue clay, with layers of sand 160

2. Sand 173

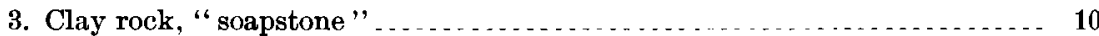

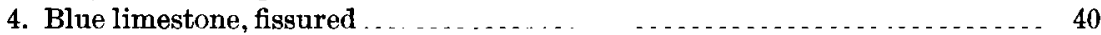

5. Gray limestone $\ldots \ldots \ldots \ldots$

6. Pure crystalline sulphur $\ldots \ldots \ldots \ldots \ldots$

7. Gypsum, with sulphur $\ldots \ldots \ldots \ldots \ldots$

8. Sulphur _...

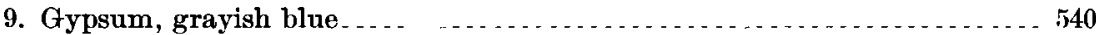

Some petroleum was found in this well to a depth of 380 feet, but in too small quantities to be commercially valuable. The incidental discovery of heavy beds of native sulphur led to the formation of a company to develop this mineral, and numerous wells were drilled for this purpose, the method of mining finally adopted being to melt the sulphur by means of superheated steam and pump it out in that condition. In all the wells put down for this purpose small quantities of oil were found from the surface down to a depth of 357 feet, and in one well drilled within the last few years the petroleum is reported to have spouted 65 feet above the casing. This well still continues to flow small quantities of a heavy black oil.

This thickness ascribed to the sulphur bed does not appear to agree with the records of the well drilled about 1892 or 1893 . At that time a test well was put down by the Diamond Prospecting Company, in which the sulphur was first found at 436 feet, below which it was found to alternate with beds of limestone down to 603 feet, the limit of the boring. The well was drilled for the American Sulphur Company and is located near the boiler house. 
Log of well drilled for American Sulphur Company at Sulphur, La.

[Drilled by Diamond Prospecting Company, with Sullivan diamond drill, size N.]

\begin{tabular}{|c|c|c|c|c|}
\hline & Character of strata. & Thickness. & From- & To- \\
\hline 1 & Clay & $\begin{array}{l}\text { Feet. } \\
\quad 167\end{array}$ & $\begin{array}{l}\text { Feet. } \\
\\
0\end{array}$ & $\begin{array}{l}\text { Feet. } \\
167\end{array}$ \\
\hline 2 & Quicksand & $134 \frac{1}{2}$ & 167 & $301 \frac{1}{2}$ \\
\hline 3 & . _ do _. & $26 \frac{1}{2}$ & $301 \frac{1}{2}$ & 328 \\
\hline 4 & Sand and gravel $\ldots \ldots \ldots \ldots$ & 17 & 328 & 345 \\
\hline 5 & Clay shale $\ldots \ldots \ldots \ldots$ & 1 & 345 & 346 \\
\hline 6 & White water shale $\ldots \ldots$ & 4 & 346 & 350 \\
\hline 7 & White clay and sand $\ldots \ldots \ldots$ & $\mathbf{5}$ & 350 & 355 \\
\hline 8 & White water spar (limestone) & 25 & 355 & 380 \\
\hline 9 & Spar (limestone) & 19 & 380 & 399 \\
\hline 10 & Sand & 1 & 399 & 400 \\
\hline 11 & Soft white water spar & 28 & 400 & 428 \\
\hline 12 & Sandy white marl & 8 & 428 & 436 \\
\hline 13 & Sulphur $\ldots \ldots$ & 3 & 436 & 439 \\
\hline 14 & Mixed limestone and sulphur & 6 & 439 & 445 \\
\hline 15 & Sulphur & 5 & 445 & 450 \\
\hline 16 & Mixed limestone and sulphur & 2 & 450 & 452 \\
\hline 17 & Sulphur $\ldots \ldots \ldots \ldots$ & 1 & 452 & 453 \\
\hline 18 & Mixed limestone and sulphur & 16 & 453 & 469 \\
\hline 10 & Black limestone and sulphur. . . & 24 & 469 & 493 \\
\hline 20 & Mixed limestone and sulphur .. & 5 & 493 & 498 \\
\hline 21 & Sulphur & 2 & 498 & 500 \\
\hline 22 & Mixed limestone and sulphur & 16 & 500 & 516 \\
\hline 23 & Sulphur $\ldots \ldots \ldots$ & 4 & 516 & 520 \\
\hline 24 & Mixed limestone and sulphur & 10 & 520 & 530 \\
\hline 25 & Sulphur $\ldots \ldots$ & 3 & 530 & 533 \\
\hline 26 & Mixed limestone and sulphur . . . . . . . . . & 8 & 533 & 541 \\
\hline 27 & Sulphur. & 2 & 541 & 543 \\
\hline 28 & Mixed limestone and sulphur & 31 & 543 & 574 \\
\hline 29 & Sulphur & 6 & 574 & 580 \\
\hline 30 & Mixed limestone and sulphur & 23 & 580 & 603 \\
\hline
\end{tabular}

From the records of wells drilled in this district the underground contours appear to resemble those at Spindletop, and the structure may be considered as a flattened dome, sloping somewhat gently from the crest toward the south and more abruptly toward the northwest. So far as developments have gone the sulphur has been proved to cover an area of approximately 30 acres, though its limits are not fully determined.

The American Sulphur Company owns the lands for several miles around these mines, and no prospecting has been done in this vicinity 
except by the sulphur company itself, and that entirely with reference to the sulphur deposits. The company is now enlarging its plant, preparatory to mining sulphur on a larger scale than heretofore. No attention has been given to the occurrence of petroleum, and although oil is the fuel used at the mines, it is shipped from Beaumont. The prospects for the development of a productive oil pool at this point are very flattering.

In sec. 28 , T. 9 S., R. 10 W., about a mile from the sulphur mine, Messrs. Mayo \& Mendelsohn have drilled a well to the depth of 450 feet. This well, which was put down with a hand drill, showed only a heavy bed of sand until gravel was eneonntered, when the work was abandoned.

\section{MINOR LOUISIANA DISTRICTS.}

VINTON.

This point is about 15 miles southwest of Sulphur. Four wells have been attempted, but only one has succeeded in reaching any considerable depth. At 440 feet a heavy bed of coarse gravel is encountered which can not be penetrated with the rotary drill, since the pebbles are from 1 to 3 inches in diameter and can not be lifted by the return water current. The Stribling well, drilled partly by the rotary process and partly with standard rig, is claimed to have reached a depth of 1,000 feet. The $\log$ of only a portion of this well has been obtained, giving the following section:

Log of portion of T. C. Stribling well at Vinton, La.

[Elevation, 20 feet.]

\begin{tabular}{|c|c|c|c|c|}
\hline & Character of strata. & Thickness. & From-- & To- \\
\hline & & Feet. & Feet. & Feet. \\
\hline 1 & Hard clay - & 20 & 0 & 20 \\
\hline 2 & Gray sand, with oil . & 10 & 20 & 30 \\
\hline 3 & Quicksand .... & 270 & 30 & 300 \\
\hline 4 & Hard gray sand _. & 50 & 300 & 350 \\
\hline 5 & White sand, with water. & 75 & 350 & 425 \\
\hline 6 & Gravel, with black sulphur water & 20 & 425 & 445 \\
\hline 7 & Large gravel . & 9 & 445 & 454 \\
\hline
\end{tabular}

The gravel bed between 400 and 500 feet yields a strong artesian flow of black sulphur water. Indications of oil are observed immediately under the 20 feet of surface clay, and at a depth of 800 feet. While the indications thus far afforded are not particularly encouraging, it can not be said that the possibilities of developing an oil pool are exhausted, and they would appear sufficient to warrant the drilling of a test well to a depth of at least 2,000 feet. 
The Sharp well, drilled on the edge of the marshy lands bordering the Sabine River, about 4 miles north of these wells at Vinton, was also abandoned in gravel at a depth of nearly 500 feet.

\section{SPRING HILL.}

A well drilled for the Spring Hill Oil Company in the NE. $\frac{1}{4}$ of SW. $\frac{1}{4}$ sec. 12 , T. 6, R. 4 , to a depth of 1,200 feet, found a small quantity of oil in a sand, which may possibly prove a fairly good pumping well. This oil has been cased off and the well is now being drilled deeper.

\section{WELSH.}

The Welsh Oil and Development Company has drilled two wells in sec. 28 , T. 9 S., R. $5 \mathrm{~W}$. In the first well petroleum was found at 1,050 feet, but not in large quantities. The well was deepened to $1, \widetilde{5} 00$ feet without finding any more oil, and in bringing back the casing to try to develop the 1,050-foot oil sand the well caved in and was lost. In well No. 2 at the date of visit the drill had reached a depth of 700 feet.

\section{LAKE CHARLES.}

Considerable drilling has been carried on in the neighborhood of Lake Charles, but so far without commercial success. The Watkins well No. 1, of the Gulf Oil and Mineral Company, near the center of sec. 16, T. 10 S., R. 8 W., has been drilled to a depth of 2,400 feet without finding petroleum. A condensed log of this well shows the following section:

Log of Watkins well No. 1, at Lake Charles, La.

[Elevation, 22 feet.]

\begin{tabular}{|c|c|c|c|c|}
\hline & Character of strata. & Thickness. & From- & To- \\
\hline 1 & Sand and clay - & $\begin{array}{l}\text { Feet. } \\
\qquad 400\end{array}$ & $\begin{array}{l}\text { Feet. } \\
0\end{array}$ & $\begin{array}{l}\text { Feet. } \\
\quad 400\end{array}$ \\
\hline 2 & Sand and gravel. . & 44 & 400 & 444 \\
\hline 3 & Clay and sand. & 106 & 444 & 550 \\
\hline 4 & Sand and gravel . & 40 & 550 & 590 \\
\hline 5 & Sand $\ldots \ldots$ & 10 & 590 & 600 \\
\hline 6 & Sand and gravel .... & 8 & 600 & 608 \\
\hline 7 & Clay $\ldots \ldots \ldots$ & 42 & 608 & 650 \\
\hline 8 & Sand, clay, and shale... & 1,750 & 650 & 2,400 \\
\hline
\end{tabular}

In the same region the Texas, Louisiana and National Company is drilling at Iloo-Hoo Park, in sec. 13, T. $9 \mathrm{~S}$., R. $8 \mathrm{~W}$. This well has reached a depth of 951 feet. 




SAND GUSHER AT WELSH. LA. 

The Forward Reduction Oil Company is drilling a number of wells in the lower Louisiana coast country. The wells of this company are located in sec. 25, T. 8 S., R. 7 W., in sec. 18 , T. 9 S., R. 10 W., where the company has three wells, and in sec. 9, T. $10 \mathrm{~S} .$, R. $11 \mathrm{~W}$. This last well is south of Edgerly. The well in sec. 25, T. 8 S., R. 7 W., is reported to have a depth of 2,100 feet, and the presence of oil is claimed in an 8 -inch sand at 1,100 feet, in another 10-inch sand at 1,314 feet and again at 1,725 feet. These oil sands are reported to be overlain with a thin capping of rock.

The Pelican Oil Company well No. 1 is being drilled in sec. 22 , $T$. $10 \mathrm{~S}$, R. R. $10 \mathrm{~W}$. When visited this boring had a depth of about 800 feet. At 509 feet a small seep of oil was passed through.

In the Foster well, in Sabine Parish, small quantities of petroleum were met with at the depths of 75,340 , and 630 feet.

The Louisiana field contains many small seeps of petroleum and escapes of gas of which no record has been kept. The structure of the country, together with the great quantity of vegetable remains inclosed in the clays, tends to produce an abundance of gas and probably petroleum, if these could be brought into a condition to be utilized.

Throughout this portion of the coast country gas escapes in great abundance, and small quantities of petroleum are of frequent occurrence in the drilling of wells for water purposes. While these small quantities form in the aggregate a considerable quantity of petroleum, owing to its generally disseminated condition it is not possible to collect it and it is therefore of no commercial value.

\section{THE GULF COASTAI PLAIN OIL.}

\section{ORIGIN OF PETROLEUM.}

\section{CLASSIFICATION OF THEORIES.}

The origin of petroleum is one of the most obscure problems by which geologists are confronted. Numerous widely different theories have been advanced and advocated by geologists and chemists during the last fifty years, but as yet there is none which can be regarded as generally accepted and of universal applicability. In the present connection any full discussion of these theories is manifestly out of place, and only a bare outline of the more important ones will be given. It should be stated, however, that numerous facts have come to light in the development of the Coastal Plain field which have a very direct bearing upon theories of the origin of the oil. These have in part been given in the preceding pages, but will be stated more explicitly in this and the following sections.

The theories may be divided into three main groups: (1) Those which attempt to explain the origin of oil by inorganic agencies, (2) 
those which ascribe it to an organic origin, and (3) those which involve both inorganic and organic agencies.

\section{THEORIES OF INORGANIC ORIGIN.}

In 1866 Berthelot suggested that water containing carbonic acid or an earthy carbonate coming in contact with metallic sodium or potassium at a high temperature might produce both liquid and gaseous hydrocarbons such as are found in various oil fields. In 1877 Mendeljeff published his theory, which remains the most plausible of all the inorganic theories thus far proposed. Stated briefly, it is that water percolating downward through fissures in the earth's crust comes in contact, under conditions of high temperature and great pressure, with metallic carbides; that a chemical reaction takes place, with the formation of metallic oxides and saturated hydrocarbons, and that the latter ascend and impregnate the porous beds of sedimentary rocks in which they are now found.

Various modifications of the theories of Berthelot and Mendeljeff have been suggested by other chemists, but these contain the essentials of all the purely inorganic theories which merit consideration.

'The fact is unquestioned that hydrocarbons similar to or identical with some of the constituents of natural petroleum may be produced in the laboratory by the action of inorganic substances, but no geologic or other evidence that these reactions actually take place in the earth's erust has been discovered. The conclusion must therefore be that while the inorganic theory is attractive it is not proved.

\section{THEORIES OF ORGANIC ORIGIN.}

These theories may be again divided into two groups: (a) That petroleum is indigenous to the rocks in which it is found, and $(b)$ that it is the product of natural distillation.

The first of these theories was advocated by Sterry Hunt, who asserted that all petroleum was formed in limestone by the decomposition of the animal remains which it originally contained. It was also advocated by Lesley and Whitney.

The theory was further amplified by Orton, who extended it to the petroleum found in the shale and sandstone in the Appalachian field as well as that found in limestone. According to Orton, ${ }^{a}$ petroleum results from the primary decomposition of organic matter, and was formed when the rocks containing it were themselves formed.

A modification of this theory has recently been advanced, namely, that the oil, instead of being the product of decomposition of organic matter, is secreted by living organisms of a low order, such as diatoms, and therefore exists as such as an original constituent of the rock in which it is found. The presence of oil associated with 
diatoms in the mud at Sabine Pass is regarded by Dr. Phillips as furnishing some degree of support to this theory.

The majority of geologists have held to the second theory, namely, that petroleum is derived from the organic matter disseminated through great masses of carbonaceous shales by the process of slow natural distillation at relatively low temperatures, and that it has subsequently migrated through the strata to the reservoirs in which it is found. In proof it is pointed out that these carbonaceous shales yield by artificial distillation a large quantity of hydrocarbons, both gaseous and liquid, which are indistinguishable from those found in nature; but the possibility of natural distillation at a temperature sufficiently low to leave the inclosing rocks entirely unchanged has not been proved, nor have the residues of carbon which would result from such distillation been found in the rocks.

Again, there is much diversity of opinion among those who hold to the organic origin of petroleum as to whether its source is in animal or vegetable remains. Peckham believes that petroleum may be derived from both animal and vegetable matter, but that the source of the organic matter determines the character of the oil, that with a paraffin base (e. g., Pennsylvania) being derived from plant remains, and that with an asphalt base (e. g., California) being derived from animal remains.

\section{THEORIES OF COMBINED ORGANIC AND INORGANIC ORIGIN.}

Among the theories which fall in the third group may be mentioned that proposed by O. C. D. Ross ${ }^{a}$ in 1891. It is that petroleum is produced by the action of volcanic or solfataric gases containing sulphurous acid and hydrogen sulphide upon limestone, with the formation of gypsum and free sulphur. The reactions given undoubtedly take place in the laboratory, and they may also take.place in certain localities in nature. On the other hand, Hopkins ${ }^{b}$ proposed a theory, which has been elaborated and modified somewhat by other chemists, according to which the gypsum is the original material and the limestone is secondary. The essential features of this theory are that gypsum, calcium sulphate, in the presence of decomposing organic matter which gives off carbonic acid, is reduced, with the formation of limestone, calcium carbonate, free sulphur, and hydrocarbons. This reaction has not been exactly reproduced in the laboratory, but neither ean the conditions which must prevail at great depths in the earth be exactly reproduced.

It will be observed that the theories of this group are intermediate between those of the first two classes. The original materials are in part organic (limestone and vegetable or animal matter) and in part inorganic (volcanic gases and gypsum). 


\section{CONCLUSION.}

This great diversity of views regarding the origin of petroleum is equaled by the diversity in character of the petroleum itself and in the geologic conditions under which it is found. In fact, it is probable that the final theory will include most of those outlined above, and will recognize the fact that this substance which is so widely distributed in nature may be the product of widely different processes acting upon a great diversity of materials. Thus the hydrocarbons which have been observed in certain volcanic rocks and in gases given off from volcanic vents may be entirely inorganic, resulting from the reaction between water and heated metallic carbides. The oil of the Appalachian field may be derived from the slow distillation of plant remains disseminated through the underlying shales, and that of the Trenton limestone of the Lima field from animal remains originally contained in the rocks in which it is now found. Finally, the oil of the Gulf Coastal Plain is probably derived, in part at least, from the action of decomposing organic matter, both animal and vegetable, but chiefly the latter, upon gypsum.

\section{ACCUMULATION OF THE OIL.}

\section{CONDITIONS FOR ACCUMULATION.}

Hydrocarbons of the petroleum type are among the most widely distributed substances in nature. They are found associated with almost all classes of rocks, both erystalline and sedimentary, from the oldest to the youngest. While these hydrocarbons are very widely distributed they are, however, usually in small quantities, and accumulations sufficiently large to be of commercial importance are restricted by certain well-defined conditions to a relatively small portion of the earth's surface. In many regions it is comparatively easy for the geologist, by an examination of surface conditions, to state definitely and with certainty that no oil in commercial quantities will be found. In other large regions he can state that oil may be found, and can point out in some cases the most favorable localities, but he can not predict the actual occurrence of an oil pool in advance of drilling.

The essential conditions for the accumulation of oil are (1) a sufficient supply of oil derived from any of the sources above described, (2) a porous reservoir rock in which it may be stored, and (3) an impervious cap rock which will prevent its escape. Conditions which favor its accumulation but are not always essential are (4) gentle undulations of the strata forming anticlinal arches or domes, (5) the complete saturation of the rocks with water and its slow circulation under hydrostatic head or convection due to differences of temperature.

THE OIL SUPPLY.

This is of course the first and most essential condition, for without it no accumulation could take place however favorable other condi- 
tions might be. Of all the conditions enumerated above, this is probably the one which prevails over the largest areas. Wherever there are heavy deposits of sedimentary rocks, some of the beds generally contain organic material, either animal or vegetable, from which an abundant supply of hydrocarbons might be derived, and at some time in the history of such beds conditions have generally been favorable for its conversion into petroleum. This is notably true of the many thousand feet of strata constituting the Cretaceous and Tertiary formations on the Gulf Coastal Plain.

\section{THE RESERVOIR ROCK.}

All granular rocks which enter into the composition of the earth's crust are to some extent permeable to liquids. This porosity, the vacant space between the rock particles, varies from less than onehalf of 1 per cent in rocks like granite to 8 or 10 per cent in ordinary compact, fine-grained sandstones, and 25 per cent or even more in coarse gravel or cavernous limestone and dolomite. The porosity of a rock depends upon the shape of the grains, their uniformity in size, and the amount of cementing material. It is wholly independent of the size of the grains. Hence a fine-grained sand may have as great capacity for holding oil as a coarse gravel. The term "oil pool" is in common use in most oil fields and is a convenient one, but is liable to lead to misapprehension. An oil pool is simply a restricted portion of any porous bed which is saturated with oil. It is limited both vertically and horizontally by some impervious barrier which prevents the escape of the oil. It does not generally contain any large fissures or caverns, the oil being contained in the minute spaces between the constituent grains of the bed. In exceptional cases, such as the Spindletop pool, where the reservoir rock is a limestone or dolomite, there are cavities of appreciable size, probably to be measured in inches and possibly in feet, in which the oil is stored as well as in the minute spaces between the constituent grains of the rock.

The character of the reservoir rock does not determine the character of the oil, but does determine its behavior when the pool is tapped by the drill. When the rock is a firm, fine-grained sandstone, it yields its oil slowly, even when under great pressure, and the yield continues for a long time, steadily decreasing, however, as the supply is drawn from increasing distances. A cavernous dolomite, on the other hand, offers little resistance to the passage of the oil toward the well, and the flow from such a rock is consequently rapid and short lived. When the oil is held in an unconsolidated sand, the latter flows toward the exit along with the oil and quickly chokes the well unless beld back by some straining device.

\section{THE IMPERVIOUS COVER.}

Since petroleum has a lower specific gravity than water, it always tends to rise when the two liquids are associated in the rocks, and 
if not stopped by some impervious barrier would continue until it reached the surface and then be dissipated. An essential condition of any large accumulation is therefore an impervious stratum which shall eheck this upward course of the oil and restrain it in a porous reservoir rock below. Such impervious strata usually consist of fine clay, clay shale, or muddy limestone. If the bed is perfectly continuous, a few feet in thickness of clay or clay shale is sufficient to prevent any leakage from the underlying porous beds even under great pressure. In the Spindletop pool the cover is formed by a considerable thickness of alternating clay beds and limestones, the lowermost of which is the so-called "cap rock."

\section{ANTICLINAL STRUCTURE.}

When oil, whatever its origin, occurs in a porous bed along with water, it tends to rise toward the surface and continues to rise until it reaches the surface or meets some obstruction. If the obstruction is a perfectly horizontal stratum of impervious material, the progress of the oil is checked, but it does not accumulate in large bodies. If, on the other hand, the impervious stratum is inclined, the oil continues to move upward along its under side until it meets a downward bend in the bed which it can not pass. 'The oil is thus trapped in the fold or anticline, and if the impervious bed is continuous over the crest it continues to accumulate and an oil pool is formed. The Appalachian field is characterized by low folds, which have a general northeast-southwest trend, parallel with the large folds of the Appalachian Mountains, and these folds have been of the highest importance in the accumulation of oil in that field. In the Gulf Coastal Plain no structures are found which at all resemble the anticlines of the Appalachian field. The latter are undoubtedly due to horizontal compression of the earth's crust, but the Coastal Plain does not appear ever to have been subjected to such compression, and consequently the long regular parallel folds are wanting. The circular or elliptical domes which have been described as occurring at Spindletop, Damon Mound, and elsewhere are structures of a wholly different class, and could scarcely have been produced by horizontal compression. Although these domes are not strictly comparable with the anticlines of the Appalachian field, they are equally efficient in furnishing the structural conditions favorable for the accumulation of oil.

SATURATION OF THE ROCKS AND CIRCULATION OF THE SATURATING FLUID.

Sedimentary rocks below the immediate surface are generally saturated with water, either fresh or saline. In some cases, particularly in the Appalachian field, the rocks are dry, and under these conditions, even when sufficiently porous, they are not readily traversed 
by oil. This condition, however, is probably very rarely present in the thoroughly saturated beds underlying the Coastal Plain.

In almost every deep well which has been drilled in the Coastal Plain small quantities of oil have been found, generally at several horizons. While this is not sufficiently abundant to be of value, it indicates the extremely wide distribution of the oil through these formations and the enormous aggregate which they must contain. If these beds were regular in thickness and character, like those underlying the Appalachian field, and were similarly folded, the oil would travel to the crests of the anticlines and accumulate in long, narrow pools. The beds of this region, however, are most irregular. No two well sections, even if closely aljoining, exactly correspond. In Ohio alone the Berea sandstone extends over 15,000 square miles with scarcely any variation in thickness and composition. In the Coastal Plain, on the other hand, no single bed can be traced without material nodification over 100 square miles. The underlying formations are composed of a vast number of overlapping lenses and the stratigraphic relations are therefore exceedingly complex. The conditions are unfavorable for the transfer of oil from place to place, and the result is that the most of it has remained disseminated through the beds. The Coastal Plain formations have a general southeastward dip of a few feet to the mile, but this has apparently not been sufficient to enable the oil to overcome the obstacles occasioned by the irregularity in the character of the bed. Under these conditions some agency in addition to mere difference in specific gravity between the oil and water was required for the segregation of the oil. This was found in the circulation of the water contained in the beds. The agency of circulating waters in the accumulation, not only of the oil in the Coastal Plain pools, but also of the associated sulphur, dolomite, and salt, has recently been suggested by IIill. ${ }^{a}$

The hypothesis is as follows: The oil and salt pockets of the Texas Coastal Plain are probably not indigenous to the strata in which they are found, but are the resultant products of columns of hot saline waters which have ascended, under hydrostatic pressure, at points along lines of structural weakness, through thousands of feet of shale, sand, and marine littoral sediments of the Coastal Plain section. through which oil and sand are disseminated in more or less minute quantities. The oil, with sulphur, may have been floated upward on these waters, and the salt and dolomite may have been crystallized from the saturated solution.

The channels of these ascending waters may have been in places of structural weakness, such as fissures, which probably at one time continued to the surface, but may have been sealed by the deposition of the later overlapping strata now capping the oil pools.

Many facts may be adduced in support of this hypothesis, although it must be admitted that it presents some serious difficulties. The mode of accumulation of the enormous masses of rock salt which occur in the Louisiana Salt Islands, in Damon Mound, in High Island,

a Robert T. Hill, The Beaumont oil field, with notes on the other oil flelds of the Texas region: Jour. Franklin Inst., 1902. 
and also in Spindletop, has never been satisfactorily explained. For a variety of reasons it does not seem possible that they can be the result of evaporation of sea water in natural salt pans, which is supposed to be the origin of most deposits of rock salt. It may therefore be necessary to refer their origin to supersaturated solutions coming from the lower strata through fissures opened along a fault line. If such fissures were open to the surface, as Hill suggests, any petroleum brought up from the lower beds by the ascending waters would escape. If the vent were subsequently sealed up by the deposition of impervious beds, the fissure might remain open and afford a means for the oil to be collected and brought up by the slow circulation of water under the influence of convection currents. It is suggested, as a possible explanation of the difference between Spindletop and Sour Lake on the one hand and Damon Mound and the Louisiana Salt Islands on the other, that the former vents were effectually sealed up after the salt had been deposited, while the latter have always remained open; the oil, which subsequently followed the same course taken by the salt solution, was in the former checked before reaching the surface, while in the latter it reached the surface and practically all escaped.

\section{STRUCTURAL CONDITIONS.}

It is suggested above that the location of the oil pools in the Gulf Coastal Plain is determined by certain structural features, namely, dislocations of the strata in the form either of faults or of anticlinal flexures. A study of the distribution of the localities at which gas, oil, and salt are known to oceur in the Coastal Plain affords some support to this theory and also suggests the districts where prospecting may be carried on with the best chances of success. It will be observed from the accompanying map (Pl. VII) that the known deposits of these associated substances occur along northeast-southwest lines. Five such lines of deposits are shown, all but one being determined by at least three points. The westernmost line contains Saratoga, Dayton, and Damon; the second contains Sour Lake, Barber Hill, Kiser Hill or Columbia, and Big Hill, Matagorda County; the third contains Spindletop, Big IFill, Jefferson County, High Island, and probably Bryan Heights; the fourth contains Sulphur, Vinton, and Sabine Pass; and the fifth, Spring IIill and Hackberry. Other points in Louisiana do not appear to observe this linear arrangement, although further investigation of this region may extend the system to include these as well as the famous Salt Islands.

It is of interest to note that these lines are almost exactly parallel to the most prominent structural feature in the entire Texas region, namely, the Balcones fault, which has been described by Hill as passing through the center of the State. Further confirmation of the significance of these lines is afforded by the work of Veatch in the salines 


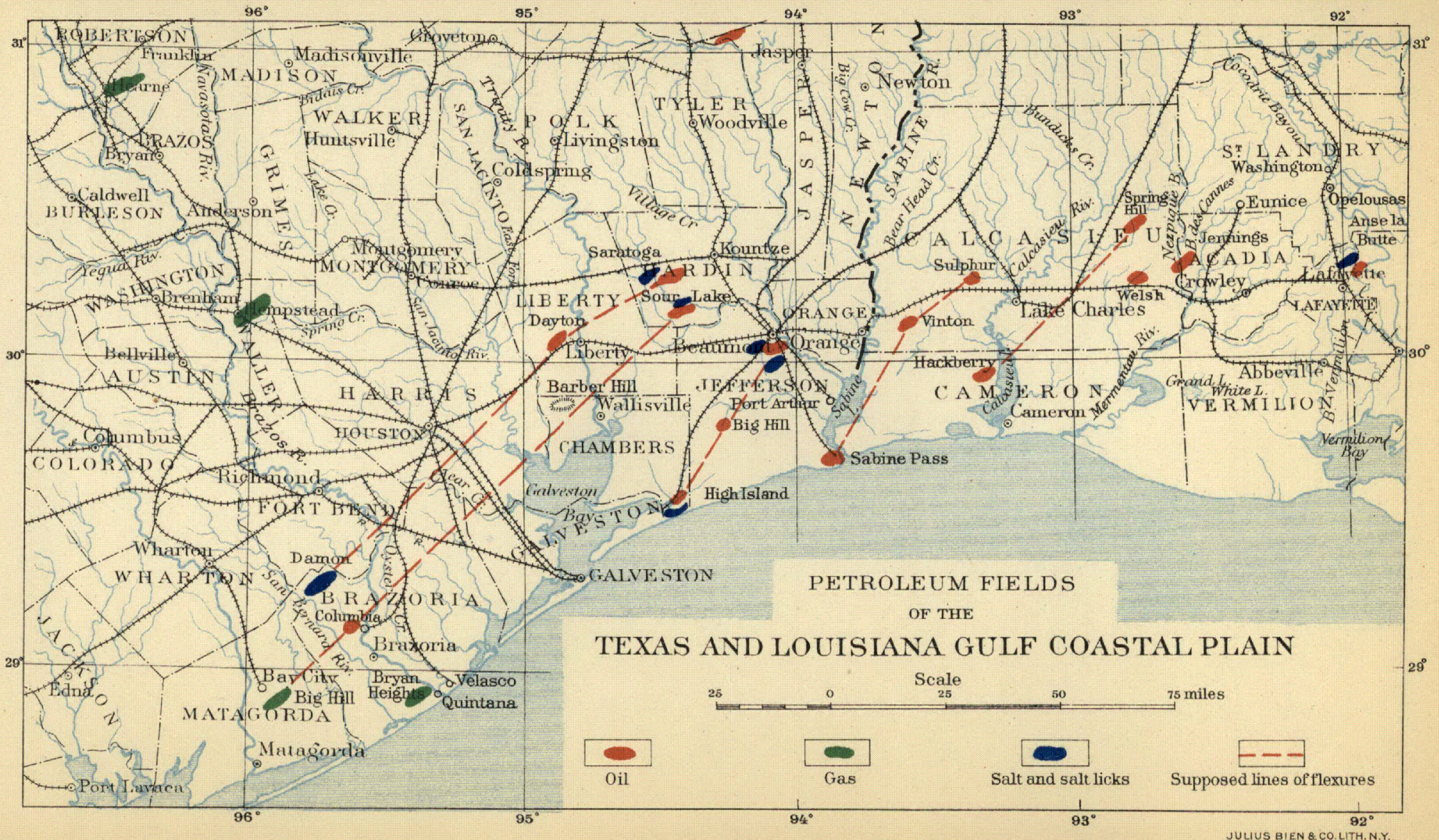



of northern Louisiana. ${ }^{~ I I e ~ h a s ~ s h o w n ~ t h a t ~ t h e s e ~ s a l i n e ~ s p r i n g s ~ a r e ~}$ associated with dome-shaped uplifts and that they fall naturally into a linear arrangement, the axes being parallel with those of the Gulf Coastal Plain and probably continuations of the same.

The lines shown on the map nay be considered as coinciding with the main structural axes of the region, which are actual or potential lines of dislocation, either by folding or by fracture. The date of initial movement on these axes can not be fixed exactly, but it must be as far back as the Miocene, since the thickness of Miocene formations is affected by the doming which has taken place at various points. The movement has been continued through the late Tertiary and into the present, since it affects the most recent deposits of the region, excepting perhaps the present river alluvium. The initial movement may even date back to Cretaceous time, and some evidence in the northern Locisiana salines points to such a conclusion.

The character of the movement can not be determined with certainty, and it doubtless includes both flexing and faulting. Its most striking characteristic appears to be the concentration of differential effect at certain points which form the mounds of uplift, of which Spindletop may be regarded as the type. It may be, however, that these local uplifts are purely secondary and are not due to the same cause which produced the axial movements; in other words, that the lines of weakness which give rise to the main structural axes merely afford the necessary favorable conditions for the development of these secondary structures.

It will be noted from the descriptions given on previous pages that the various domes differ widely in amount of elevation. This is shown by a comparison of Sour Lake and Spindletop with High Island and Damon Mound. The former elevations are much less conspicuous than the latter, which have passed beyond the point where they are adapted to form oil reservoirs. It is quite possible, therefore, that there are other elevations even less conspicuous than Spindletop, or perhaps not at all apparent at the surface, which may be equally well adapted for oil reservoirs. Such structures might easily escape notice if no elevation had taken place upon them since the deposition of the recent clays.

If such inconspicuous or entirely obscured structures do exist, as seems probable, they will almost certainly occur along the lines indicated on the accompanying map, and along these lines, therefore, are the best places for conducting systematic prospecting in the Gulf Coastal Plain. It should be fully understood in advance that the chances of finding oil by drilling at any particular point along these lines are small, but they are much larger than the chances of finding it by drilling at random anywhere on the Coastal Plain.

aThe salines of north Louisiana, by A. C. Veatch: Geological Survey of Louisiana, Report for 1902

Bull. $212-03-10$ 


\section{PHYSICAL AND CHEMICAL PROPERTIES OF THE TEXAS-LOUISIANA OIL.}

PHYSICAL PROPERTIES.

COLOR AND ODOR.

When flowing from the well or first received into the tank the Beaumont petroleum is a dark reddish-brown fluid, carrying a large quantity of hydrogen sulphide in solution. It has a very strong, disagreeably pungent, sulphurous odor, attacking the mucous membranes of the nose and causing the eyes to smart. The Sour Lake oil and the Saratoga and Jennings oils are somewhat darker and heavier, and, owing to the smaller quantity of gas which they contain, have a less disagreeable odor. The small quantity of oil flowing from the Equitable Mining Company's well at Columbia is also of a very dark color.

Upon exposure to the air these oils gradually lose a large proportion of their contained gases and become somewhat thicker and darker. They do not, however, lose their peculiar odor. Kast and Lagai attribute the odor of petroleum to the presence of unsaturated hydrocarbons, while Mabery and Smith appear to think it is due to a mixture of bad-smelling compounds, but do not say what may be the cause, although they found unsaturated hydrocarbons in their experiments with the Ohio oils. ${ }^{a}$ Richardson ${ }^{b}$ also found considerable quantities of unsaturated hydrocarbons in the Beaumont oils.

\section{SPECIFIC GRAVITY.}

The specific gravity of the Beaumont petroleum ranges from 0.904 to 0.925 , or $25.4^{\circ}$ B. to $21.5^{\circ} \mathrm{B}$. 'Three determinations of the Sour Lake oil gave it specific gravities of $0.945,0.958$, and 0.963 , or $18^{\circ} \mathrm{B}$. to $15^{\circ} \mathrm{B}$. The Saratoga oil has a specific gravity of 0.945 , or $18^{\circ} \mathrm{B}$.

A comparison of the specific gravities of the petroleum from various districts of the Coastal Plain field with those of other well-known fields shows the former to be much heavier than any of the petroleums which contain a notable proportion of illuminants. They are, however, in this respect similar to the California oils. Some of the Mexican oils are also heavier.

\section{Specific gravity of petroleum from various fields.}

Pennsylvania :.... 
Mexico $a_{\ldots} \ldots \ldots \ldots \ldots \ldots$

Beaumont $b \ldots \ldots$. . . . . . . . . . 25

Wyoming $a \ldots \ldots \ldots 12-.945$

California $c \ldots \ldots \ldots \ldots \ldots$

Saratoga (Hooks No. 1) $d_{\ldots} \ldots \ldots \ldots 7$

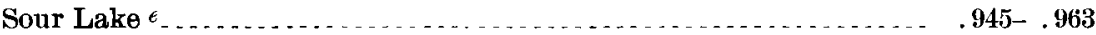

Brazoria County, Tex. $d_{\ldots} \ldots \ldots \ldots \ldots$

Borneo $a_{\ldots} \ldots \ldots 5$

FLASH AND BURNING POINT.

A roughly approximate ratio exists between the specific gravity of any petroleum and its flashing point, and as a general rule a low specific gravity accompanies a low flashing point, and while the burning point of an oil is usually from $10^{\circ}$ to $15^{\circ}$ higher than the flashing point, this is not always the case. An oil having a high flashing point always has a high burning point, but, on the other hand, a high burning point may be accompanied by a low flashing point.

The flashing test of an oil is made for the purpose of determining the lowest temperature at which it gives off an inflammable vapor, and is the most important test which can be applied to any petroleum, since it is to the inflammable vapor evolved at ordinary temperatures that most of the accidents are due. This point is quite independent of the burning point and depends altogether upon the character and amount of the volatile constituents, while the burning point depends upon the character and composition of the oil as a whole.

The presence of the lighter hydrocarbons lowers the flashing point, since these volatilize more readily than the heavier hydrocarbons. The effect of benzine in varying. proportions in lowering the flashing point, as determined by Wilson, $f$ is shown in the following table:

Effect of nixture of benzine on flashing point.

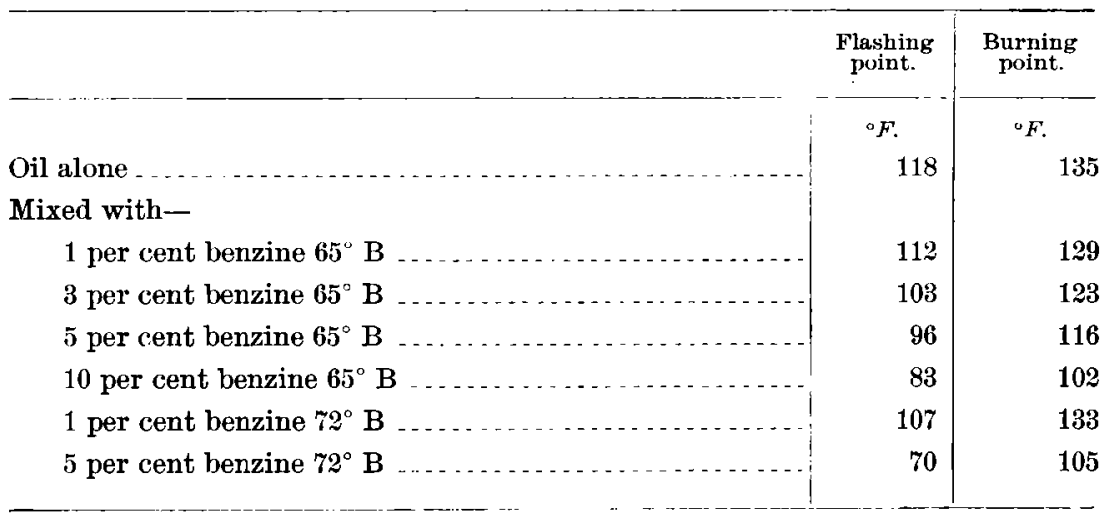

a Redwood, Petroleum and its Products, 1886, Vol. I, p. 178.

$b$ Jour. Soc. Chem. Industry, Vol. XX, p. 691 et seu.

c Watts, Oil and gas: Bull. Cal. State Mining Bureau No. 19, p. 204

d Worrell, analyst, Texas Mineral Survey.

$e$ Jour. Soc. Chem. Industry, Vol. XIX, p. 122 .

$f$ Crewe, Practical Treatise on Petroleum, 1887, p. 359. 
Very few tests of the Coastal Plain oils have been made with the view of determining either their flashing point or their burning point, and the few made show very discordant results. The differences are probably due, in part at least, to the different length of time during which the various samples had been exposed to the air, with consequent evaporation of the more volatile constituents.

Flashing point and burning point of Beaumont oil.

\begin{tabular}{|c|c|c|}
\hline Determined by- & $\begin{array}{c}\text { Flashing } \\
\text { point. }\end{array}$ & $\underset{\text { point. }}{\text { Burning }}$ \\
\hline & ${ }^{\circ} \mathrm{F}$ & ${ }^{\circ} \mathrm{F}$. \\
\hline Ledoux $a_{-}$ & 165 & \\
\hline Richardson $^{b}$ & 110 & \\
\hline Emery .... & 110 & 180 \\
\hline Denton $c$ & 142 & 181 \\
\hline Oliphant $d$ & 180 & 200 \\
\hline
\end{tabular}

a Trans. Am. Inst. Min. Eng., Vol. XXXI, p. 360.

b Jour. Soc. Chem. Industry, Vol. XX, p. 691 . c Report to Export Oil and Pipe Line Co. d Mineral Resources U.S. 1890 , p. 580.

It appears from the above that in the use of this oil in its crude state no danger need be apprehended from fire due to the generation of inflammable gases if its temperature is kept below $110^{\circ} \mathrm{F}$., and that by the gradual escape of the lighter hydrocarbons the temperature at which dangerous gases are given off rises in a comparatively short, time to $180^{\circ}$, or even higher. This conclusion is amply confirmed by a series of experiments made by Professor Denton to determine this point.

VISCOSITY.

The physical character of petroleum is more or less affected by low temperatures. Some experiments made with the Saratoga oil show that prolonged cold has but a slight effect upon it. A test tube filled with the crude oil was submerged in the freezing tank of the Austin Ice Factory for sixteen hours. The temperature of the tank at the time of immersion was $22^{\circ} \mathrm{F}$, , and at the close of the experiment the temperature had risen to $26^{\circ} \mathrm{F}$. Another test tube was surrounded by a freezing mixture so as to reduce the temperature of the oil to $10^{\circ} \mathrm{F}$., and it was kept at this for half an hour. In both cases the oil showed only a slight thickening and did not run as freely as at ordinary temperatures. Other experiments made by Ledoux, Emery, and Denton have shown that the Beaumont oil remains liquid at $10^{\circ} \mathrm{F}$.

The viscosity of the Beaumont oil, according to the Pennsylvania Railroad standard, is 77 seconds, as compared with 42 seconds for the Pennsylvania and 37 seconds for the Noble, Ohio, oils.

\section{CHEMICAL PROPERTIES.}

Our information regarding the chemical properties of the TexasLouisiana oils is derived chiefiy from the work of Messrs. Thiel, 
Mabery, and Richardson, whose results and conclusions are given below. The properties investigated include ultimate composition, volatility, products of fractional distillation, viscosity of residues, specific gravity, and refractive index of distillates. For the purpose of comparison, determinations of the same oroperties in oils from other fields are also inserted.

COMPOSITION.

The ultimate chemical composition of the Beaumont and Sour Lake oils as compared with oils from other fields is given below.

Ultimate composition of various oils.

\begin{tabular}{|c|c|c|c|c|c|c|}
\hline & \multicolumn{2}{|c|}{ Beaumont. } & $\begin{array}{c}\text { Sour } \\
\text { Lake. } .\end{array}$ & $\begin{array}{c}\text { Pennsyl- } \\
\text { vania, }\end{array}$ & Obio.a & $\begin{array}{l}\text { Califor- } \\
\text { nia.r }\end{array}$ \\
\hline C. & a 85. 08 & $b 84.60$ & $8 \pi .96$ & 86.10 & 85 & 84 \\
\hline $\mathrm{H}_{-}$ & 12.30 & 10.90 & 13.97 & 13.90 & 13.80 & 12.70 \\
\hline $\mathbf{S}$ & 1.75 & 1.63 & $\ldots$ & .06 & .60 & .40 \\
\hline O. N $\ldots$ & .92 & 2.87 & & & .60 & 2.09 \\
\hline $\begin{array}{l}\text { Loss on treatment with ex- } \\
\text { cess of } \mathrm{H}_{2} \mathrm{SO}_{4} \ldots \ldots \ldots\end{array}$ & 39 & & & 21.00 & 30 & \\
\hline
\end{tabular}

a Jour. Soc. Chem. Industry, Vol. XX, p. 161 et seq.

$b$ Report of the Liquid Fuel Board, United States Navy, 1902, p. 69.

c Salathe, Bull. Cal. State Mining Bureau No. 19, p. ari.

The sulphur content of the Beaumont petroleum is high and it also carries a large amount of hydrogen-sulphide gas in solution. This gas largely escapes on standing, and is more completely expelled if air or steam is blown through the oil. After such treatment Richardson found the oil to contain 1.75 per cent of sulphur. Mabery found 2.16 per cent; Denton found 1.63 per cent; O. H. Palm found the IIiggins oil to contain 2.4 per cent of sulphur, and A. M. Smoot found the oil from the Lucas well to contain 2.04 per cent.

According to Mabery, ${ }^{a}$ the Ohio oils have 0.50 per cent of sulphur, while the Canadian oils contain, according to the same authority, 0.98 per cent. Orton and Lord ${ }^{b}$ found 0.553 per cent in the Trenton limestone oils.

The condition in which this sulphur exists in the petroleum is an important question from the technological standpoint, since it will determine the methods to be adopted for its removal. Considerable light is thrown on the question by experiments in the fractional filtration of this oil, carried on by Dr. D. T. Day, and described at the Petroleum Congress in Paris in 1900.

The oil from which the hydrogen sulphide had been removed by a current of air was passed through a filter made by packing kaolin in a glass tube 19 inches in length. The oil entered the bottom of the 
tube under a head of 56 inches and passed through very slowly, only 5 cubic centimeters having passed in the first twenty-four hours.

The color, odor, specific gravity, and sulphur content of the several fractions obtained in this manner are given below.

Filtration products from Beaumont oil.a

\begin{tabular}{|c|c|c|c|c|c|}
\hline & $\begin{array}{l}\text { Amount } \\
\text { in c.e. }\end{array}$ & Color. & $\underset{\text { gravity } 25 \mathrm{C} .}{\text { Specific }}$ & Sulphur. & Remarks. \\
\hline Crude oil. & ... & Deep brown & 0.914 & $\begin{array}{c}\text { Per cent } \\
1.75\end{array}$ & Rank odor. \\
\hline First fraction & 5 & Water white & .8755 & .80 & Sweet odor. \\
\hline Second fraction. & 21 & Pale lemon & .8986 & .91 & Do. \\
\hline Third fraction ..... & 8 & Deep lemon ... & .9038 & 1.04 & Do. \\
\hline Fourth fraction & 22 & $\begin{array}{l}\text { Amber fluores- } \\
\text { cent. }\end{array}$ & .9068 & $y$ & Do. \\
\hline Fifth fraction & 10 & _. $d o$ & .9104 & & Do. \\
\hline Sixth fraction & 22 & Deep amber & & & Do. \\
\hline Seventh fraction. & 13 & .... do . & .9115 & & Do. \\
\hline Eighth fraction. ... & 20 & .... do .... & .9115 & & Do. \\
\hline
\end{tabular}

a Jour. Soc. Chem. Industry, Vol. XXI, p. 31T.

On standing for a month or more the denser fractions, and especially the second, deposited beantifully regular crystals of sulphur. These could only have been derived either from the decomposition of sulphur compounds while passing through the filter or from sulphur existing as such dissolved in the oil. The latter appears the more probable, aithough further investigation is required to settle the question definitely.

\section{VOLATILITY.}

The volatility of the Beaumont petroleum as compared with oils from Noble County, Ohio, and the Pennsylvania pipe line is shown by Richardson to be as follows:

Relative volatility of Beaumont oil.

\begin{tabular}{|c|c|c|c|c|c|}
\hline & $\begin{array}{l}\text { Sour } \\
\text { Lake. }\end{array}$ & $\begin{array}{l}\text { Beaumont } \\
\text { No. } 1 .\end{array}$ & $\begin{array}{l}\text { Beaumont } \\
\text { No. } 2 .\end{array}$ & $\begin{array}{c}\text { Noble } \\
\text { County, } \\
\text { Ohio. }\end{array}$ & $\begin{array}{c}\text { Pennsyl. } \\
\text { vania pipe } \\
\text { lines. }\end{array}$ \\
\hline & Per cent. & Per cent. & Percent. & Percent. & Percent. \\
\hline $110^{\circ}$ C., $230^{\circ}$ F., 7 hours $\ldots \ldots$ & & 19.19 & 20 & 41.2 & 47.3 \\
\hline $162^{\circ}$ C., $325^{\circ}$ F., 7 hours $\ldots$ & & 31.31 & 27 & 43 & 58 \\
\hline $205^{\circ}$ C., $400^{\circ}$ F., 7 hours . . ..... & 35 & 57.57 & 49 & 59 & 68 \\
\hline To constant weight: & & & & & \\
\hline $105^{\circ}$ C., $221^{\circ}$ F., 42 hours. & - & 48 & 48 & 48.7 & 58 \\
\hline $162^{\circ} \mathrm{C} ., 325^{\circ} \mathrm{F} ., 70$ hours. & & $a 64$ & 57 & 61 & $b 71.8$ \\
\hline $205^{\circ} \mathrm{C}_{.}, 400^{\circ} \mathrm{F}_{.}, 49$ hours & & 74 & 74 & 75 & 84 \\
\hline
\end{tabular}


The distillation as carried on in Engler's flasks gave the following results :

Distillation of Beaumont oil. .

\begin{tabular}{|c|c|c|c|c|c|}
\hline & $\begin{array}{l}\text { Sour } \\
\text { Lake. }\end{array}$ & Berumont. & Ohio. & $\begin{array}{l}\text { Pennsyl- } \\
\text { vania. }\end{array}$ & California.a \\
\hline Distillation begins ${ }^{\circ} \mathrm{C}$. & & 110 & 85 & 80 & \\
\hline Below $150^{\circ}$ C. per cent & $\ldots$ & 2.5 & 23 & 21 & 7.6 \\
\hline $150^{\circ}-350^{\circ}$ C. p. cent & $\begin{array}{r}6.6 \\
b 12.7\end{array}$ & 40 & 21 & 41 & 14.2 \\
\hline $300^{\circ}-350^{\circ}$ C. p. cent & 2.6 & 20 & 21 & 14 & 5.2 \\
\hline $350^{\circ}-400^{\circ}$ C. p. cent & & 25 & $2 \pi$ & $\begin{array}{l}23 \\
99\end{array}$ & \\
\hline $\begin{array}{c}\text { Loss on acid treatment, } \\
\text { per cent }\end{array}$ & & 10 & 5 & 1.8 & \\
\hline $\begin{array}{c}\left(150^{\circ}-300^{\circ} \text { C. fraction }\right) \\
150^{\circ}-260^{\circ} \text { per cent }-\end{array}$ & & 30 & & & \\
\hline $\begin{array}{l}\text { Loss on acid treatment, } \\
\text { per cent }\end{array}$ & & 8 & & & \\
\hline Percentage of acid used . & & $\tau$ & 2.5 & 2 & \\
\hline
\end{tabular}

a Bulletin California State Mining Bureau No. 19, p. 203.

$b$ Cracking begins. Residue in Sour Lake oil, 78.1 per cent.

The percentage, specific gravity, and refractive index of the fiactional distillates from the Beaumont oil, as determined by Richardson, are as follows:

Fractional distillates.

\begin{tabular}{|c|c|c|c|c|c|}
\hline & \multicolumn{2}{|c|}{ Fractions. } & \multirow{2}{*}{ Distilled. } & \multirow{2}{*}{$\begin{array}{l}\text { Specific } \\
\text { gravity } \\
26 \text { C. }\end{array}$} & \multirow{2}{*}{$\begin{array}{l}\text { Refractive } \\
\text { index } 26 \mathrm{C} .\end{array}$} \\
\hline & ${ }^{\circ} \mathbf{F}$. & ${ }^{\circ} \mathbf{C}$. & & & \\
\hline & & & Per cent. & & \\
\hline Atmospheric pressure & $300-401$ & $149-245$ & 1 & 0.8114 & 1.459 \\
\hline Do & $401-441$ & $205-227$ & 8.4 & .8408 & 1.461 \\
\hline Do . & $441-480$ & $227-249$ & 4.4 & .8569 & 1.467 \\
\hline Do . . . . & $480-520$ & $249-271$ & 10.8 & .8705 & 1.476 \\
\hline Do . . . . & $520-559$ & $271-293$ & 10.8 & .8863 & 1.485 \\
\hline Do $\ldots$ & $559-602$ & $293-317$ & 13.1 & .9009 & 1.492 \\
\hline 20 millimeters pressure & $392-464$ & $200-240$ & 13 & .9184 & 1.505 \\
\hline Do .... & $464-536$ & $240-280$ & 8.8 & .9349 & 1.514 \\
\hline Do _. & $536-608$ & $280-320$ & 10.6 & .9429 & 1.521 \\
\hline
\end{tabular}

Residue slow flow at $70 \mathrm{~F}$. 
The viscosity of the residues from the open-dish evaporation of the Beaumont oil is as follows:

Viscosity of residues of Beaumont oil.

7 hours at $205^{\circ} \mathrm{C} ., 400^{\circ} \mathrm{F}$. Quick flow.

49 hours at $205^{\circ}$ C. $400^{\circ} \mathrm{F}$ Solid.

Penetration, $8^{\circ}-10^{\circ}$.

A similar but softer pitch made by boiling the crude oil for twenty hours in an open dish had the following properties compared with a D grade residue or paving asphalt from Los Angeles oil:

Character of residues of Beaumont and California oils.

\begin{tabular}{|c|c|c|}
\hline & Beaumont. & California. \\
\hline Penetration & $78^{\circ}$ & $78^{\circ}$ \\
\hline Specific gravity ........ & .9943 & .9964 \\
\hline Bitumen soluble in $88^{\circ}$ naphtha & 78.3 & 74.4 \\
\hline Bitumen soluble in $62^{\circ}$ naphtha & 84.3 & 81.6 \\
\hline Fixed carbon & 8.7 & 15 \\
\hline
\end{tabular}

Richardson has called attention to the peculiar conditions under which the sulphur exists in the Beaumont petroleums and the probability of the presence of free sulphur which might account for the variability in character of the product obtained on varying the conditions under which the oil is heated, the amount of hard residue reaching in some cases to no more than 10 per cent and under other conditions to as much as 35 per cent.

Distilled in vacuo at a point where boiling ceased to go on without cracking, one of the samples from Beaumont gave distillates better suited for examinations as to the character of the hydrocarbons which make up the oil than those from the Engler flasks. Comparisons of the distillates from Corsicana, Sour Lake, and California oils show that the Beaunont petroleum is more closely related, as would be expected, to the Sour Lake than to the other oils.

Specific gravity of fractions boiling between $100^{\circ}-1 \% 5^{\circ} \mathrm{C}$.

\begin{tabular}{|c|c|c|}
\hline & $100^{\circ}-150^{\circ}$ & $150^{\circ}-175^{\circ}$ \\
\hline Beaumont .......... & 0.8637 & 0.8868 \\
\hline Sour Lake. & .8693 & .9056 \\
\hline Corsicana .... & .7932 & .8187 \\
\hline California $\ldots \ldots \ldots$ & .9195 & .9547 \\
\hline
\end{tabular}


The specific gravity and refractive index of the Beaumont distillates as compared with those from the Ohio and Pennsylvania oils are shown as follows:

Character of distillates.

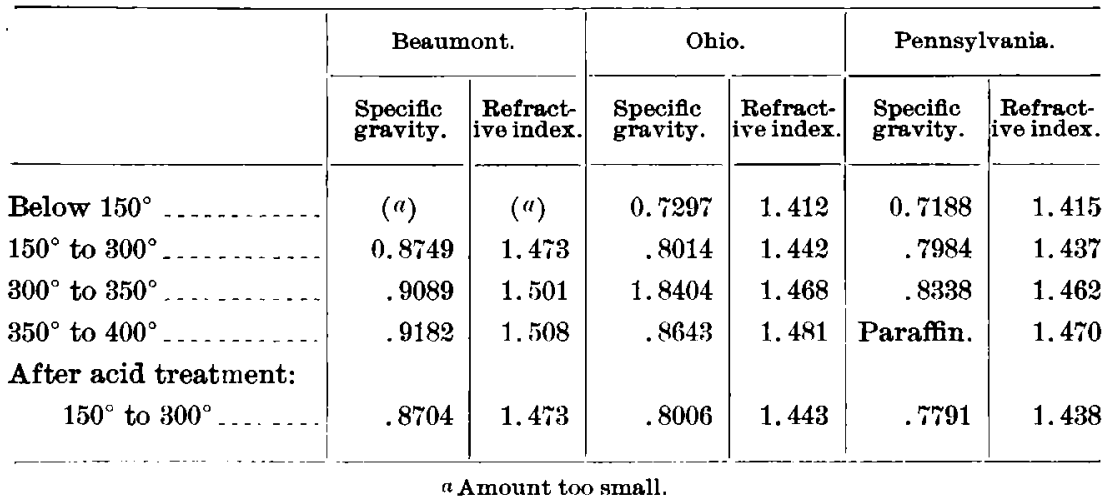

The residue after distillation of the Beaumont oil, amounting to 9.9 per cent of the original oil, was evaporated in an open dish to 6 per cent. It was then a brittle pitch which had the following properties:

Properties of residue after distillation of Beaumont oil.

Specific gravity . . . . . .

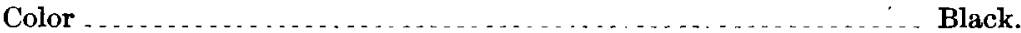

Luster . . . . . . . . . . . . . . . . . . . . . . . . . . . . . . . . .

Structure $\ldots \ldots \ldots \ldots \ldots$ Massive.

Fracture . . . . . . . . . .

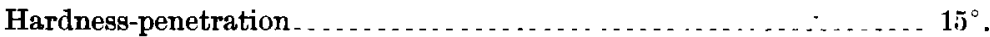

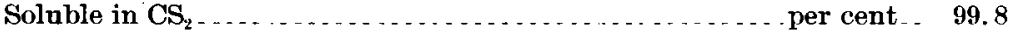

Organic insoluble $\ldots .1$

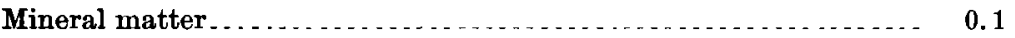

Soluble in $88^{\circ}$ naphtha

This is per cent of total bitumen $\ldots \ldots \ldots .6 \ldots$

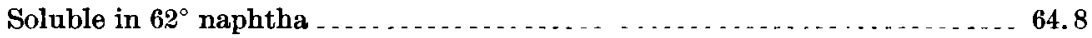



Bitumen yields on ignition-

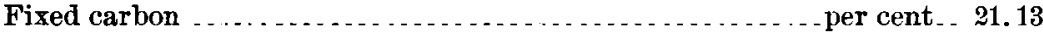

Volatile hydrocarbon … $\ldots \ldots \ldots$

CONSTITUTION.

The chemical constitution of the Texas petroleum has not yet been thoroughly investigated, but Richardson and Wallace in the article quoted above $^{a}$ reach the conclusion that it contains a large proportion of unsaturated hydrocarbons, which are removed by treatment with an excess of strong sulphuric acid and washing soda. It also 
contains members of a hydrocarbon series $\mathrm{C}_{n} \mathrm{H}_{2 n}-2$, which, although saturated, are readily attacked by cold nitric acid. Similar compounds are found in Russian and Californian oils and in Trinidad asphalt.

Mabery and Buck" have also investigated the constitution of the Beaumont oil and conclude that fractions distilling between $150^{\circ} \mathrm{C}$. and $300^{\circ} \mathrm{C}$. contain hydrocarbons of the series $\mathrm{C}_{n} \mathrm{II}_{2 \mathrm{n}}-2$ and $\mathrm{C}_{n} \mathrm{H}_{2 n}-4$.

\section{ASSOCIATED HYDROCARBONS.}

NATURAI, QAS.

Throughout the whole of the Gulf Coastal Plain wherever any oil has been found, it is always accompanied by considerable quantities of natural gas; indeed, this form of hydrocarbon is more widely distributed than the oil, and at several localities it is found unaccompanied by oil. Among the most remarkable of these gas wells are those at Bryan Heights, Brazoria County, and Big Hill, Matagorda County. The gas horizon was struck at 900 to 1,000 feet and the initial pressure was sufficient to blow out tools and casing and wreck the derrick. The flow from each of these wells was estimated from $5,000,000$ to $6,000,000$ cubic feet per day. All efforts to control the flow of gas have proved unsuccessful and they have been abandoned.

The composition of the gas has not been carefully investigated, but it is known to contain, in addition to the light hydrocarbons of ordinary natural gas, a large proportion of sulphureted hydrogen. Hence, while the gas is inflammable and may be used with advantage under boilers standing in the open, and is so used extensively on Spindletop, it is not suitable for domestic use or where the products of combustion would be objectionable. It is highly probable that this gas will be utilized in future for developing heat in such industrial processes as burning brick, evaporating salt, etc. It is as yet a wholly undeveloped industry, being entirely overshadowed by the production and marketing of the oil.

\section{WELI PHENOMENA.}

WELI PRESSURE.

At numerous points in the Coastal Plain oil field, but particularly at the Spindletop pool, the oil issues from its reservoir under great pressure, producing the familiar phenomenon of gushing. Just how great the pressure has been in the Spindletop wells is not known, but it certainly varies between wide limits. In some wells it has shown almost explosive violence, blowing out casing and breaking heavy cast-iron valves. This maximum pressure has never been even 
the depth to which the well is drilled into the oil rock; and their rapidity, and consequently the yield of the well, is generally increased by deeper boring. It is also probably influenced by the character of the oil rock, the more porous rock yielding its contained oil more rapidly than that which is relatively compact. In addition to this longer period, the stream of oil generally shows a very rapid pulsation, similar to that observed in a jet of mingled water and steam when a boiler is blown off.

A common method of raising oil in wells which do not flow is to carry air under high pressure to the bottom of the well by means of a small pipe within the casing. When the air is turned on and accumulates sufficient pressure to lift the column of oil in the casing, the oil is expelled in a pulsating stream exactly similar to a natural gusher. In one case, however, the expansive force of artificially compressed air is the expelling force, and in the other case it is the expansive force of the naturally compressed gas which is associated with the oil in the rock reservoir.

In addition to the expansive force of the gas, there is also probably some hydrostatic pressure in this field, but its influence in producing the phenomena of a gusher must be relatively insignificant. Quite generally throughout the Coastal Plain region an artesian water flow is obtained at depths ranging from 600 to 1,500 feet, but this has only a very molerate head. This is seen in the 1,400 -foot artesian well at the Beaumont court-house, where the head is only a few inches above the surface. The existence of a slight hydrostatic pressure in the Spindletop pool is shown in the invasion of some wells by salt water as the overlying gas and oil are removed. This will doubtless continue until the pool is exhausted, although the head may not be sufficient to bring the salt water to the surface.

If the pressure to which the gushing in the Spindletop and other Coastal Plain pools is due is chiefly the expansive force of gas, it follows that this force will expel only a part of the oil, and the remainder will necessarily be won by pumping or by supplying the place of the natural gas by compressed air. If the oil and gas were arranged in the order of their specific gravities and sharply separated by a plane surface, the gas, being at the top, would naturally be first tapped and would escape without lifting the oil. It would foree the oil out only from such wells as did not tap the reservoir in its higher portions, but lower down where the oil reached entirely to the cover, by exerting a downward pressure on the oil. The conditions theoretically existing in an oil pool are shown in the accompanying sketeh (fig. 9). The well $\mathrm{A}$ taps the top of the reservoir and yields only gas; the well $B$, on the side of the reservoir, penetrates only oil-bearing rock and the oil is forced out by the downward pressure of the overlying gas; the well $C$ penetrates the reservoir rock below the lower limit of the 
oil, and hence yields only water which may or may not flow at the surface.

These simple theoretical conditions are, however, seldom, if ever, realized in nature. It is evident that the oil and gas in the TexasLonisiana pools are not sharply separated by a plane surface. Some of the wells on Spindletop, it is true, have yielded only gas, and certain portions of the reservoir inust therefore contain only that form of hydrocarbon, as shown on the diagram; but these gas wells are not all shallower than some which have yielded oil, and hence the two substances are not separated by a horizontal plane. It is probable that under the pressure existing in the oil reservoir the liquid hydrocarbons absorb a very large volume of the gaseous compounds, and

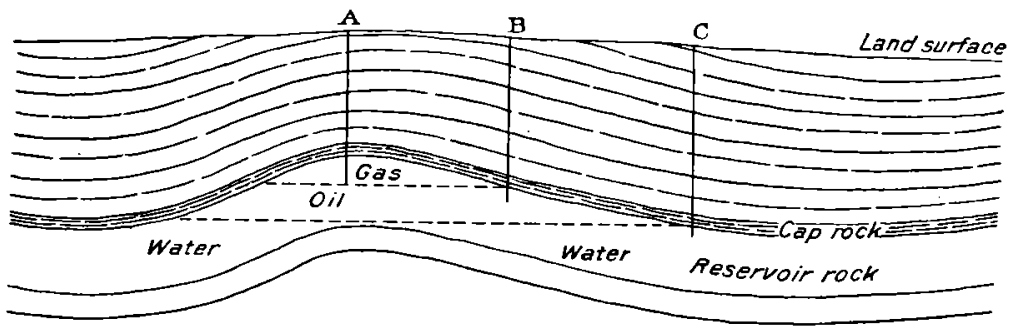

F1G. 9.-Theoretical relations of gas, oil, and water in the reservoir rock.

it may be that the expansion of this absorbed gas is the principal agent in causing the oil to gush.

\section{UTILIZATION OF THE GULF COAST PETROLEUM.}

\section{ILLUMINATING OIL.}

The three chief purposes for which petroleum is used are, in the order of profit to the producer, for illuminants, for lubricants, and for fuel. Concerning the adaptability of the Gulf Coast oil for the first two purposes, there is much diversity of opinion, and sufficient investigation has not yet been given to the subject to yield definite conclusions. The general consensus of opinion appears to be, however, that the petroleum is not adapted to the production of illuminating oil by any refining process at present known. This is not due chiefly to the presence of sulphur compounds, for methods have been devised for removing the sulphur economically, but to the chemical constitution of the distillates themselves. Being what are known as unsaturated hydrocarbons, they have a high specific gravity and burn with a smoky flame. This difficulty can not at present be overcome except by very expensive processes of refining, which are not practicable in competition with the cheap illuminating oils from other petroleums. 
FUEL.

THEORETICAL VALUE.

The value of any fuel depends upon several considerations. Commercially, upon its location and capability of successfully competing with the other fuels that may be brought, into the same market. These conditions are largely governed by the cost of production, length of haul, and cost of transportation and handling. Under certain conditions it may be possible for an inferior fuel to successfully compete with and even supplant a much higher grade fuel. Thus wood has been enabled in many localities to compete successfully with coal. Under similar conditions coal has been enabled to meet the inroads of gaseous or liquid fuel in its various forms.

Technically, fuels are graded by the work they will perform. 'This is determined either theoretically from the chemical composition or by practical tests, and the results obtained by these two methods often vary widely. It is a well-known fact that many, if not all, coals have a calculated theoretical calorific value much greater than they really possess, as shown in their ordinary use or even as measured by a calorimeter.

In the testing of fuels the heat value as determined by their chemical composition is the best method yet devised, at least for comparison of new and untried fuels. By this means their relative value as compared with other well-known fuels may be determined and some idea be gained as to their approximate commercial values. By calculating the theoretical heating power various uncertain quantities are eliminated, such as style of and condition of grates, method of setting and form of boiler, draft, and a number of other conditions which can not be rendered uniform. In the testing of liquid fuel there are the questions of the size and style of burner, quantity of steam or air, or both, admitted to fire box, and a number of other practical conditions, all of which have a direct effect on the result and greatly complicate the problem.

The theoretical value of any fuel depends upon its constituents and upon their mode of arrangement. Carbon and hydrogen are considered the essential heat producers. The other constituents being generally present in small quantities are usually disregarded, with the exception of sulphur and ash. Sulphur is generally considered as a deleterious constituent of any fuel, not only on account of its low heat power, but also on account of the readiness with which it combines with the metals in the furuace. Where fuel is intended for metallurgical purposes it is required to be as free from sulphur and sulphurous compounds as possible.

The ultimate calorific value of Beaumont petroleum as determined by Redwood is 19388 B. T. U., and as determined by Professor Den- 
ton with oxygen calorimeter is $19060 \mathrm{~B}$. T. U., giving a mean of 19224 B. T. U. The calorific value of Pennsylvania and Ohio crude petroleum is about 20200 B. T. U., and that of Baku, Russia, crude about 19500. It will thus be seen that the calorific value of the Beaumont petroleum compares favorably with that of the best liquid fuels in use.

SAFETY.

Liquid fuel, however, requires other qualifications than merely highheating values. It must be safe for transportation, handling, and for storage. Very few petroleums as they come from the well have these qualifications. All contain a greater or less percentage of naphtha or some of the lighter hydrocarbons which have a tendency to reduce the flash point and make the oil easily inflammable. Consequently a liquid fuel to be safe should not contain any of these light inflammable oils, nor should it contain naphtha. According to Oliphant, fuel oils should have a gravity of between $20^{\circ}$ and $25^{\circ} \mathrm{B}$ (sp. gr. 0.9333 to 0.9032 ) and a flash test of from $240^{\circ}$ to $270^{\circ} \mathrm{F}$. The Astatka, or fuel oils of the Russian fields, have a specific gravity of $21^{\circ} \mathrm{B}(0.928)$ and a flash point of about $284^{\circ} \mathrm{F}$., while those of the Eastern Archipelago have a specific gravity of 0.970 and a high flash point.

The effect of a mixture of the lighter oils with the petroleums is the tendency to create an inflammable vapor in counection with their storage, which, mixed with air, becomes highly explosive. It has been found that a mixture of only 2 per cent of air with this vapor makes an explosive mixture, and that upon dilution to 4 per cent or over the mixture is harmless, although still inflammable.

The few tests of the Beaumont oils have shown them to contain a sinall quantity of light oil, and to have a flash point correspondingly low. The flash point as determined ranges between $110^{\circ}$ to $180^{\circ} \mathrm{F}$. for Beaumont and $244^{\circ} \mathrm{F}$. for the oils from the Sour Lake shallow wells.

These oils, however, appear to be very slow in the generation of inflammable gases. 'Two tanks in the Beaumont fields have already been struck by lightning without any explosion or even serious fire taking place, and Professor Denton, in a series of experiments, shows that the Beaumont oil does not give rise to an inflammable vapor until heated to above $142^{\circ} \mathrm{F}$. For complete safety, however, these oils should be distilled so as to remove enough of the lighter constituents to bring the flash point up to about $240^{\circ}$, although they have been and are now being utilized with apparently perfect safety for fuel purposes in their crude condition.

The introduction of earthen and practically open tanks, allowing the lighter products to escape by a process of natural distillation, may be expected to bring them within the safety limits as to flash point without further treatment. 
PRACTICAL TESTS IN STEAM RAISING.

The most thorough practical experiments, with the view of testing the full value of the Beaumont petroleum, have been made by Prof. James E. Denton, of the Stevens Institute of Technology, Hoboken, N. J. These tests were made in the plant of the West Side Hygeia Ice Company, of New York. From the data thus obtained it appears that this petroleum has an evaporative power of 15.29 to 15.55 pounds of water per pound of oil used. Of the steam generated 3.1 to 4.8 per cent was used by the burner in spraying the oil. There was thus left available for use the steam from $14.7 \pm$ to 15.16 pounds of water per pound of oil used. Buckwheat anthracite coal used under the same boilers evaporated from 8.75 to 9.17 pounds of water per pound of fuel. In other words, Professor Denton has demonstrated that in boilers well proportioned and carefully handled 78.5 per cent of the entire calorific value of the oil was made effective. In ordinary practice, without the use of special precautions to guard against waste, 13 pounds of water should be evaporated by 1 pound of Beaumont petroleum, as compared with 6 to 6.5 pounds of water evaporated by the bituminous coals of Indian Territory, 8.7 pounds by Pittsburg coal, and 9 by Pennsylvania anthracite.

COMPARATIVE FUEL VALUE OF COAL AND BEAUMONT PETROLEUM.

The relative fuel value of petroleum and various standard coals may be obtained by comparir. $g$ the amount of water evaporated by one pound of the various fuels. Taking 13 pounds as the amount evaporated by 1 pound of Beaumont petroleum under ordinary conditions, and 6.5 pounds as the amount evaporated by Southwestern bituminous coal under similar conditions, the ratio $\frac{13}{6.5}$ is 2 . If a better grade of coal is used, the ratio will be smaller. Thus, with Pittsburg coal, which evaporates 8.7 pounds of water, the ratio $\frac{13}{8.7}$ would would be 1.5 .

The average specific gravity of Beaumont petroleum is about .921, so that it weighs 7.68 pounds to the gallon, or about 322 pounds to the barrel of 42 gallons.

Taking the first ratio, 2 , obtained above from the comparison of the evaporation by Beaumont petroleum and southwestern bituminous coal, it will be seen that 1,000 pounds of petroleum is required to do the work of 1 ton of coal of 2,000 pounds; or, since 1,000 pounds is equivalent to 3.1 barrels, 1 ton of Southwestern bituminous coal may be regarded as having the same fuel value as 3.1 barrels of petroleum. The following table gives the value of Beaumont petroleum for steam-raising purposes compared with two standard grades of coal at prices varying from $\$ 1$ to $\$ 7$ per ton. 
Comparative fuel value of coal and Beaumont petroleum.

\begin{tabular}{|c|c|c|c|c|c|}
\hline $\begin{array}{c}\text { Price of } \\
\text { South- } \\
\text { western } \\
\text { coelper ton } \\
\text { of } 2,000 \\
\text { pounds. }\end{array}$ & $\begin{array}{c}\text { Number of } \\
\text { barrels of } \\
\text { Beanmont } \\
\text { petroleum } \\
\text { to equal } \\
1 \text { ton of } \\
\text { coal. }\end{array}$ & $\begin{array}{c}\text { Price of } \\
\text { Beaumont } \\
\text { petroleum } \\
\text { per barrel } \\
\text { to equal } \\
\text { cost of } 1 \\
\text { ton of } \\
\text { South west- } \\
\text { ern coal. }\end{array}$ & $\begin{array}{c}\text { Price of } \\
\text { ordinary } \\
\text { Pittsburg } \\
\text { coal per } \\
\text { ton of } 2.000 \\
\text { pounds. }\end{array}$ & $\begin{array}{l}\text { Number of } \\
\text { barrels of } \\
\text { Beaumont } \\
\text { petroleum } \\
\text { to equal } \\
\text { 1 ton of } \\
\text { Pittsburg } \\
\text { coal. }\end{array}$ & $\begin{array}{c}\text { Price of } \\
\text { Beaumont } \\
\text { petroleum } \\
\text { per barrel } \\
\text { to equal } \\
\text { cost of } 1 \\
\text { ton of } \\
\text { Pitsburg } \\
\text { coal. }\end{array}$ \\
\hline$\$ 1.00$ & 3.1 & 80.32 & $\$ 1.00$ & 4.31 & \$1). 23 \\
\hline 1.25 & 3.1 & .40 & 1.25 & 4.31 & .30 \\
\hline 1.50 & 3.1 & .49 & 1.50 & 4.31 & .35 \\
\hline 1.75 & 3.1 & ז & $1 . \pi 5$ & 4.31 & .41 \\
\hline 2.00 & 3.1 & .65 & 2.00 & 4.31 & .47 \\
\hline 2.50 & 3.1 & .80 & 2.50 & 4.31 & .58 \\
\hline 3.00 & 3.1 & .97 & 3.00 & 4.31 & .70 \\
\hline 3.50 & 3.1 & 1.13 & 3.25 & 4.31 & .83 \\
\hline 4.00 & 3.1 & 1. 29 & 4.00 & 4.31 & .93 \\
\hline 4.50 & 3.1 & 1.45 & 4.50 & 4. 31 & 1.05 \\
\hline 5.00 & 3.1 & 1.61 & 5. 00 & 4.31 & 1.16 \\
\hline 6.00 & 3.1 & 1.94 & 6.00 & 4.31 & 1.39 \\
\hline 7.00 & 3.1 & 2. 22 & 7.00 & 4. 31 & 1.62 \\
\hline
\end{tabular}

It should be noted, however, that the conditions under which coal and petroleum are used in ordinary ppactice favor the obtaining of a larger per cent of the theoretical fuel value in the petroleum than in the coal. Also a deduction of at least 10 per cent should ordinarily be made from the fuel cost of petroleum on account of economy in handling the liquid fuel as compared with coal. Additional benefits connected with the use of petroleum are cleanliness, heathfulness, and absence of smoke, which, however, can not easily be estimated in a money equivalent.

It has been urged that the extremely disagreeable odor of the Beaumont oil will militate against its use as a fuel and that in densely settled districts its use will not be permissible. It may be positively stated, however, that when the burners are in good, clean working order no odor whatever can be detected from the burning oil, and when it is used in locomotives the absence of dirt and cinders is the only noticeable feature.

\section{LOCOMOTIVE TESTS.}

As a locomotive fuel, petroleum has many additional advantages over coal. Among the more important of these are the perfect control under which it is held and its quick response to the great variations in demand made upon the boiler. Also in the narrow limits of

Bull. 212-03-11 
a locomotive firebox the combustion is much more complete with petroleum than with coal, and a correspondingly larger proportion of the theoretical fuel value is utilized. This may amount to as much as 30 per cent added to the efficiency of the boiler. A further great advantage in locomotive use is that it weighs only 67 per cent as much as coal having the same heating capacity.

Practical tests of Beaumont petroleum have been made by the Southern Pacific Railroad and the Gulf, Colorado and Santa Fe Railroad. Both of these roads had already had experience with California petroleum, and were therefore in a position to carry out their experiments in a practical way. According to Mr. Stillman, of the Southern Pacific road, the specific gravity of the oil used was $0.9594\left(16^{\circ} \mathrm{B}\right)$. It had a flash point of $240^{\circ} \mathrm{F}$. and fire test of $290^{\circ} \mathrm{F}$. The results of the test on this road, as compared with coal, are shown in the following table:

Comparative test of petroleum and coal for locomotive fuel.

\begin{tabular}{l|r|r|r}
\hline & & & \\
\hline
\end{tabular}

$a$ Barrels of 42 gallons.

${ }^{b}$ Ton of 2,000 pounds.

From this test it appears that with petroleum at 30 cents per barrel, which is somewhat above the market price prevailing at the time the test was made, coal should be worth only 93 cents per ton; or, stated in another form, with coal at $\$ 3$ per ton, petroleum should be worth 97 cents per barrel.

METHODS OF BLRNING THE OIL.

Of the numerous styles of oil burners on the market, practically all consist of various modifications of the sprayer. Some of the earlier styles were of a different pattern, but these have been abandoned. The burners now in use all work on the principle of spraying or, as some claim, vaporizing the oil by the use of steam or air under considerable pressure, working somewhat on the style of a Bunsen burner. When steam is used it should be taken from the highest part of the"boiler and should be dry. It need not be superheated as was at one time considered necessary.

When working properly the flame is a clear white with an intense 


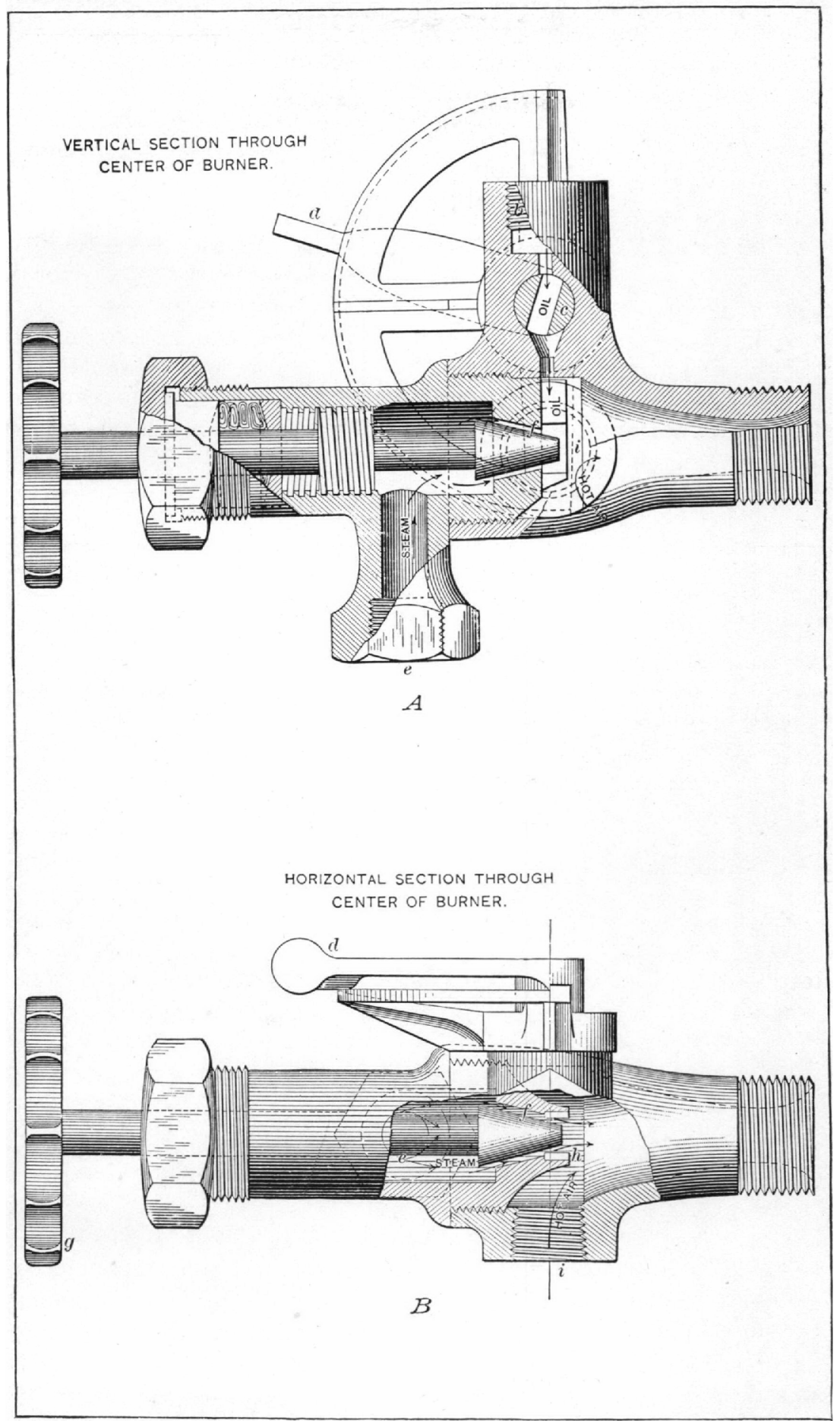



heat, and as the fuel is completely consumed no smoke issues from the chimney. When perfect combustion is interrupted by a too rapid feed of oil or an insufficient supply of air, an intensely black smoke pours from the stack in great volumes, covering everything it touches with a black, greasy soot. Ender these conditions the flame becomes a dull red, the oil is not consumed, and, although more fuel is used, less work is performed. When steam is used in excess the smoke is white and watery owing to the condensation of the steam. Under these conditions the fire usually goes out.

In making his experiment Professor Denton used the Williams burner. His arrangements for burning the oil probably represent the

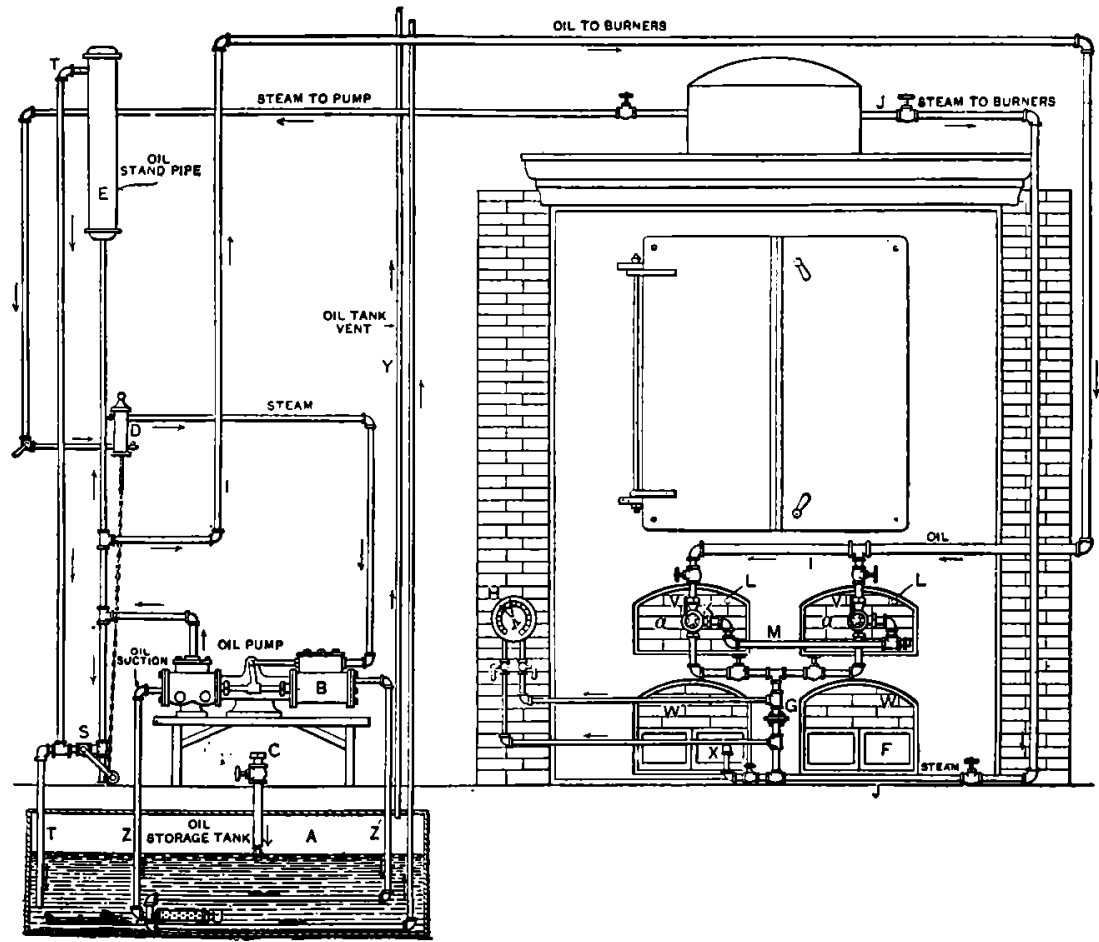

FIG. 10.-Boiler furnace with oil-burning equipment.

best practice yet devised, and, with his modifications of the boiler furnace, are shown in figs. 10 and 11 .

Four ducts of hollow tile (F, fig. 11) 10 by 6 inches were laid in the ash pit, extending nearly to the bridge wall, and the ash-pit door openings closed by brickwork around the outer ends of the tile.

The forward bearer of the grate bars ( $N$, fig. 11) was dropped, about half of the forward set of bars removed, and a course of fire brick (O, fig. 11) laid with fire clay over the whole upper surface of the grates, so that air entering through the tile could flow back along the outside of the latter, and then around and up between the front end 
of the grate bars through an area a little greater than that of the aggregate cross section of the tiles.

A checkerwork (P, fig. 11) of about 50 loose fire brick was built over the grates, the space back of the bridge was filled with ashes (R, fig. 11) flush with the top of the bridge wall, and a single-course floor ( $Q$, fig. 11) of fire brick laid over the ashes.

An iron bar ( $a$, fig. 10) was bridged across the middle of the firedoor opening, and the remainder of the latter closed with fire brick ( $V$, figs. 10 and 4 ) flared on the inside, a small opening ( $L$, fig. 10) being left for applying the torch to the burners. Into the iron bar across each door was screwed the burner ( $\mathrm{K}$, fig. 11).

Oil enters the burner vertically throngh the opening (b, Pl. VIII) under control of the cock (c, Pl. VIII), regulated by the handle (d, Pl. VIII, $A$ and $B$.)

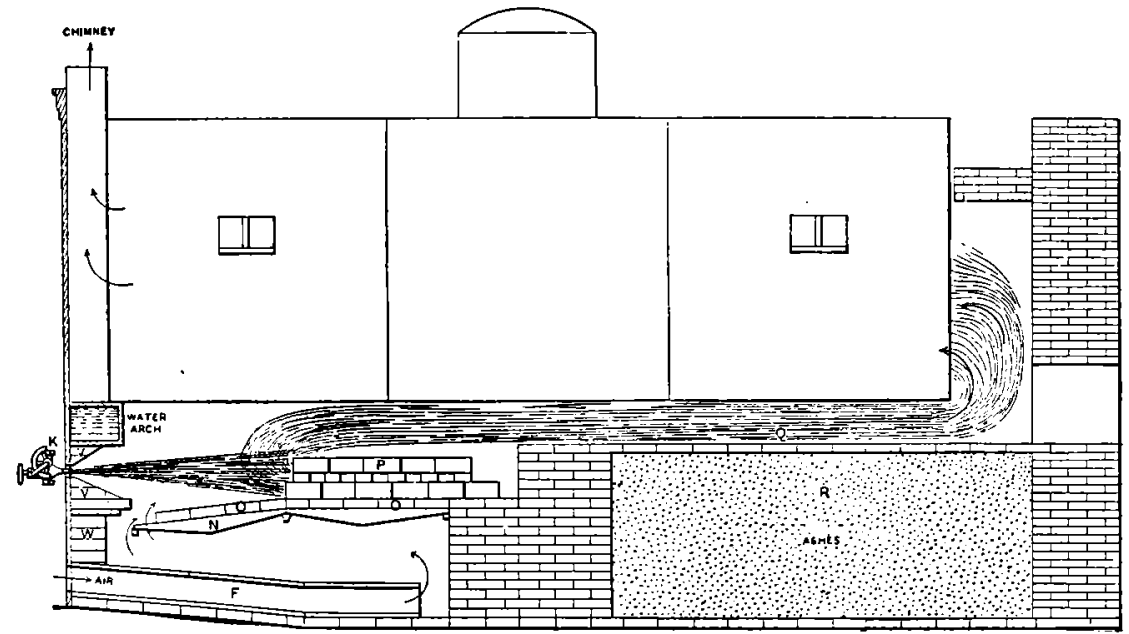

Fra. 11.-Boiler furnace arranged for burning oll.

Steam enters the opening (e, Pl. VIII, $A$ and. $B$ ) and flows through the conical opening (f), regulated by the hand wheel $(\mathrm{g})$, to meet the oil as the latter falls between the vertical flanges $(h, B)$.

$A$ third opening (i, $A$ and $B$ ) in the burner draws air from the back of the furnace through a fire-brick duct built on top of the grate and connecting with the bottom side of the latter at its rear, while the front end communicates with the iron pipe (M, fig. 10) connected to both burners.

A mixture of steam, oil, and heated air is therefore blown out of the burner, and this is joined by the main current of air flowing up around the front end of the grate bars, somewhat heated by its passage along the under side of the grate.

The oil was stored in an iron tank (A, fig. 10), 7 feet in diameter by 5 feet deep, sunk in the ground, into which the oil is emptied 


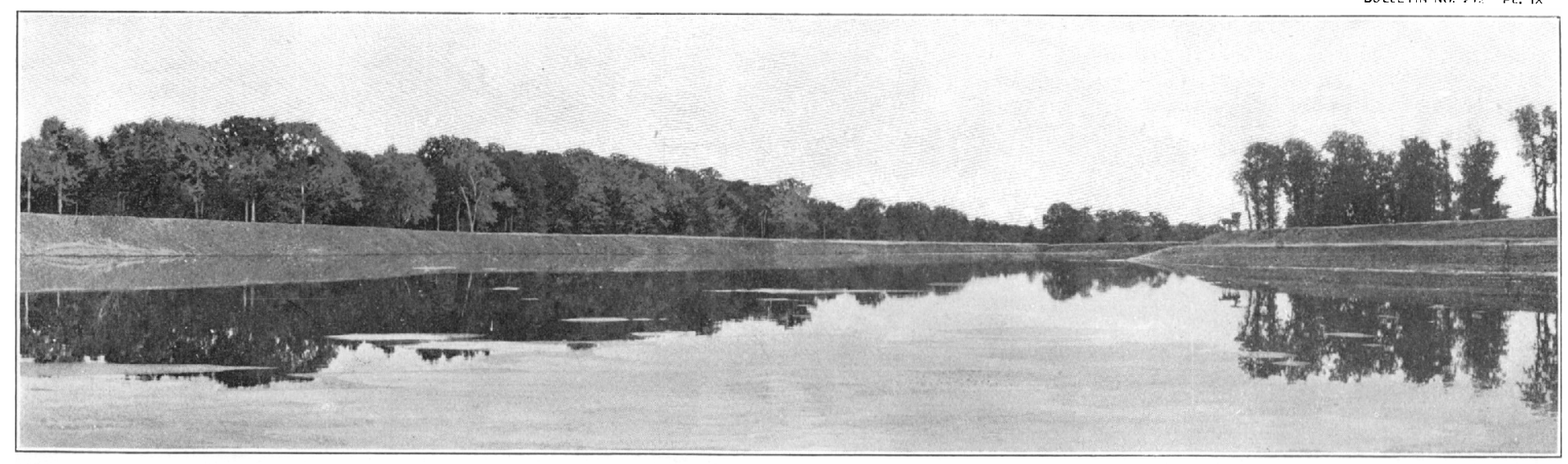

BABBITT SYNDICATE EARTHEN OIL RESERVOIR. 

through the pipe (C, fig. 10). The top of the tank was elosed, ventilation being afforded by the pipe ( $\mathrm{Y}$, fig. 10).

A steam pump (B, fig. 10) drew oil from the tank through the strainer (U, fig. 10) to the burners under a head of about 10 feet.

The pump was run constantly and delivered a surplus, which flowed back to the tank throngh the pipe (T, fig. 10).

The oil was provided with a device ${ }^{a}(\mathrm{D}$, fig. 10) having a piston connecting by a chain with a cock (S, fig. 10), which automatically opened when the boiler was not under steam pressure, so that the standpipe would be emptied of oil br the latter flowing to the storage tank.

The steam exhaust of the pump passed through the tank by the pipe ( $Z^{\prime}$, fig. 10) and thence to the atmosphere. Thereby high cold test oil is kept sufficiently fluid in cold weather to flow freely into the strainer, but is not sensibly heated to the touch when it arrives at the burner.

The air entered the ash-pit tiles under the natural draft of the chimney, 70 feet high by 42 inches square, connecting to the boiler tested by a 40 -inch flue about 30 feet long.

\section{STORAGE AND TRANSPORTATION.}

During the earlier days of the Beaumont field the companies owning wells were seriously handicapped by the want of means of taking care of the oil or sending it to market. The immense quantity produced was unexpected and no one was prepared to handle it. The companies had no tankage, and consequently, although drilling was carried on, and even stimulated beyond all reason, the wells, as soon as determined to be flowing wells, were closed until such times as the owners could make arrangements to dispose of the oil.

The railroad companies were not in a position to furnish ears, and for months looked upon the fields as a sort of freak that would soon die, and they considered themselves hardly justified in the purchase of new cars to supply the demand. These roads delayed action until several of the larger and wealthier companies commenced purchasing individual cars and shipping in that way. These companies own over 1,000 cars, and the railroads are now supplying nearly enough additional cars to meet the demand.

Pipe lines were laid to the coast at Port Arthur and Sabine Pass, and shipments by water were made from these ports. At present there are four pipe lines to Port Arthur, two to Sabine Pass, and one to Beaumont to connect with the Gulf, Colorado and Santa Fe Railroad. The water shipments are mostly coastwise to New Orleans, Mobile, Philadelphia, and other coast harbors. Considerable quantities are also shipped to European ports by the Shell Transport and 
Trading Company, which has two steam tank ships of 60,000 barrels capacity in the trade regularly.

The tankage in the field to the middle of 1902 amounted to about seven and a half million harrels, of which about four and a half million barrels were steel and nearly two million barrels earthen tanks. There are a few small wooden tanks scattered throughout the field, but these are used mostly as measuring tanks and not to any great extent for storage purposes.

Considerable interest is being taken in the construction of earthen tanks in this field, since, if satisfactory, these can be constructed at a much less cost than the steel structures. Some of these earthen tanks have nothing done to them beyond excavating to the required depth; others are lined with timber, and while some of them are open, others are covered with a light board roof.

The capacity of the steel tanks ranges from 10,000 to 55,000 barrels, while the earthen tanks range from 25,000 to 350,000 barrels.

For fire protection the steel tanks are surrounded by a moat and embankment, giving a storage capacity equal to the full content of the tank.

METHODS AND COST OF WELL DRILLING.

\section{ROTARY METHOD.}

The rotary mothod of drilling is the one used almost exclusively in the Gulf Coastal Plain oil fields. This appears to be a modification of the Fauvelle system, invented in 1845 , and used for some time in several of the European oil fields. It is unquestionably the most rapid and economical method where the formations to be penetrated are for the most part unconsolidated. The vast amount of drilling done in this field since the spring of 1901 and the keen competition among the drillers has brought the method and machinery to a high state of efficiency.

The rotary is so entirely different from the old-fashioned cable rig and churn drill that it has been thought desirable to insert a brief account of the machinery and method.

\section{MACHINERY AND OPERATION.}

There are three styles of rotary drill in the field, differing slightly in cletails, but all working on the same principle. The form in most common use, the Chapman patent, has been taken for illustration. A general view of the derrick with machinery in place is shown in fig. 12, the rotary in $\mathrm{Pl}$. $\mathrm{X}, A$, and the hoisting and operating machinery in Pl. $\mathrm{X}, B$.

The method consists essentially in rotating a vertical drill rod, through which a continuous stream of water is forced downward. The drill rod is supported by a cable passing from a hoisting drum 


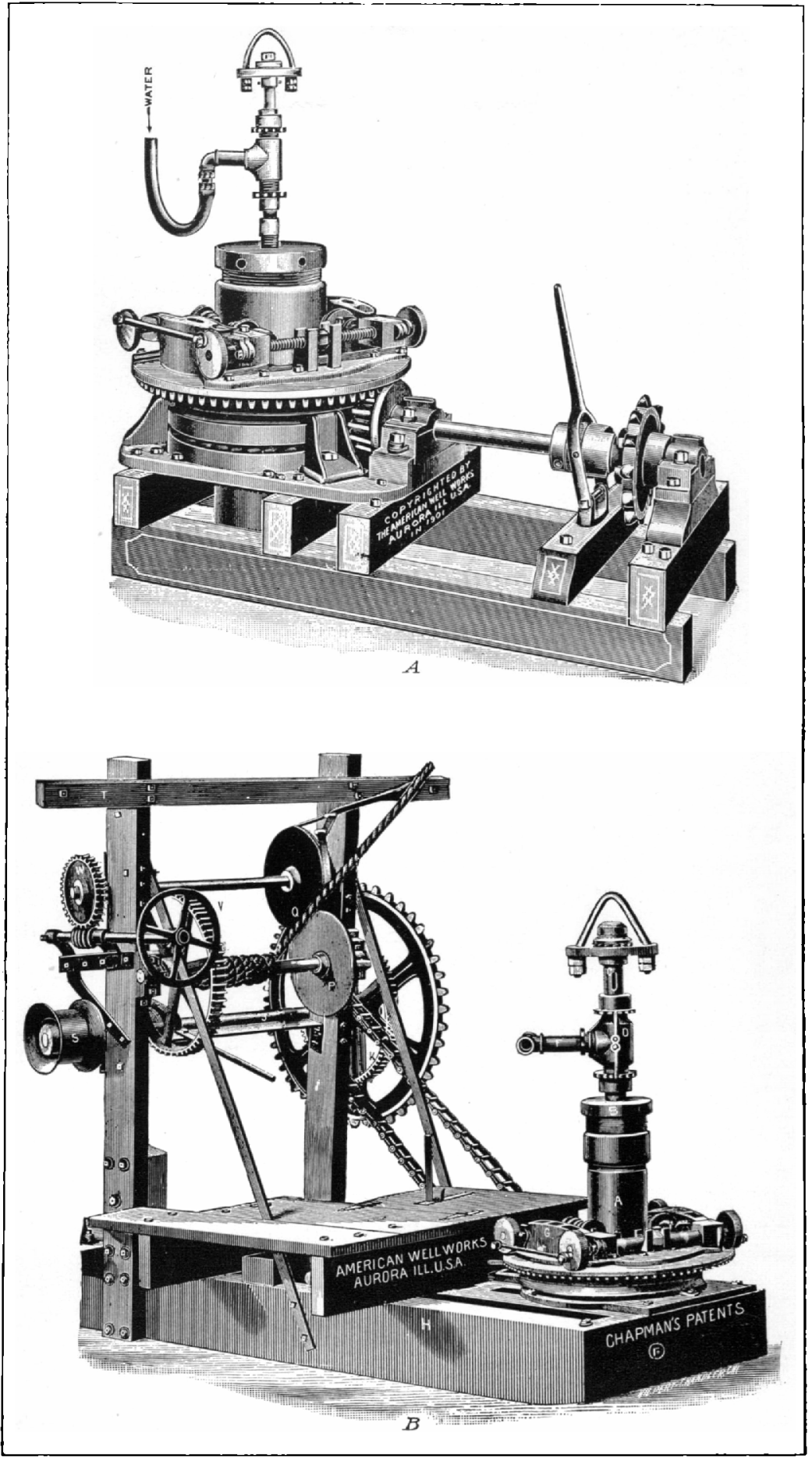

-i. CHAPMAN ROTARY LRILL.

I. HOISTING AND OPERATING MACHINERY. 

over a pully at the top of the derrick and thence by block and fall to a swivel attached to the top of the drill rod, the descent of the latter being controlled by the driller by means of a feeding device. The lower end of the drill rod is supplied with one of several forms of bit, adopted to the kind of material being drilled. The material loosened by the rotating bit is carried upward to the surface by the water ascending on the outside. This ascending current of water keeps the hole clean and allows the drill rod to turn freely. It is essential that the flow of water should be continuous, and a drilling outfit is always supplied with two force pumps in order to avoid any danger of stopping the flow. If the well has passed through a pervious stratum, such as a bed of loose sand, the ascencling water is liable to pass into that stratum instead of returning to the surface. This quickly results in the clogging of the hole, and in order to prevent it the water which is pumped in is mixed with a large amount of fine clay. By this means the outlets through porous beds are sealed up, the unconsolidated material forming the walls of the hole is prevented from caving, and the water returns unimpeded to the surface.

The forms of bits most commonly used are shown in Pl. XI, $A, B, C$. The fish-tail bit $(A)$ is adapted to soft materials, such as sand and clay. The core barrel bit $(B)$ is better aclapted for harder materials, such as very compact clay, indurated sand, etc. Where rock is encountered the ordinary bits make very slow progress, and the drilling is greatly facilitated by the use of the adamantine, or shot, drill, the cutting being done by a quantity of steel shot which revolve under the rim of the tube $(C)$. Some drillers, in passing through hard rock, rig up a regular churn drill, the cable passing over a pulley at the top of the derrick and thence down to the engine fly wheel, where a turn around the crank pin gives the required lifting-and-ctropping motion to the drill.

When everything is ready to begin operations a length of rod with the bit attached is made fast to the water swivel and lifted into the derrick. The bit and lower end of the rod are passed through the rotary far enough to allow the jaws to be brought together and clamped so as to hold the drill rod and rotate it. The driller starts the engine and sets the pump in motion. As soon as the water flows freely he slackens the friction and allows the drill to descend.

The force of water, which varies from 40 pounds to 75 or 80 pounds, passing through the rod finds its way as jets through two holes, one on either side of the fish-tail bit, and washes the freshly loosened sand up to the surface through the space between the drill rod and the wall of the well. As the work progresses the driller lowers the rod slowly, holding it stationary or letting it descend, according to the character of the material through which the bit is working. From this time on the whole responsibility rests upon the judgment of the driller. The drilling crew generally consists of four men-the driller, 
two derrick men, and the fireman-with a corresponding night shift, as the work proceeds night and day.

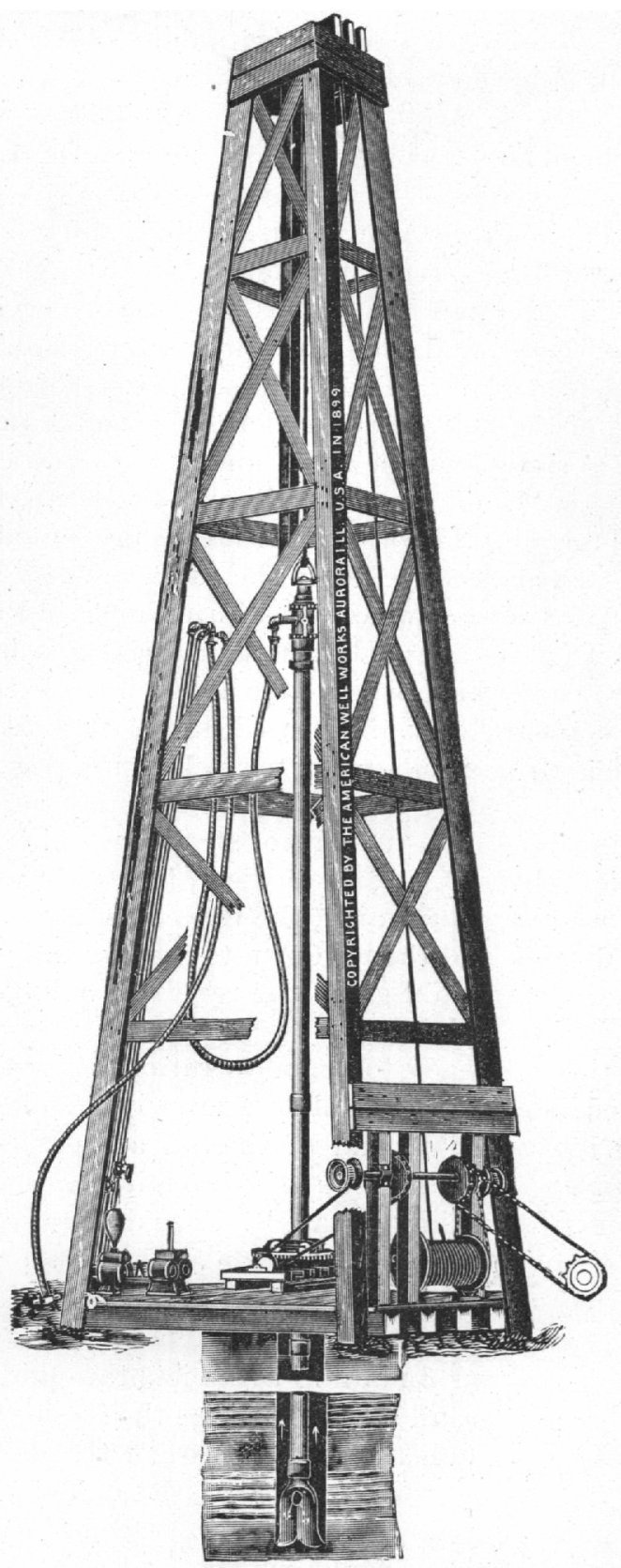

FIG. 12.-Derrick with machinery in place.

The work progresses rapidly at first, but becomes slower as the drill goes downward. Great care is required to keep the drill in motion 


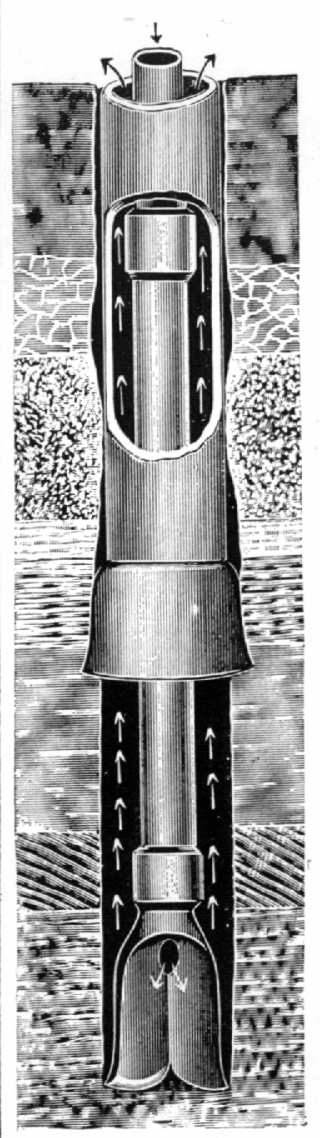

$A$
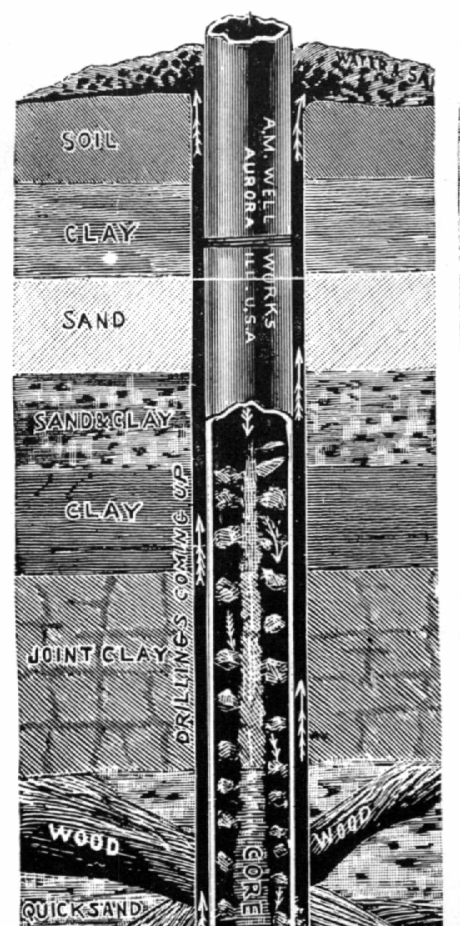

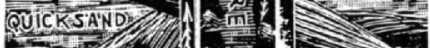



E

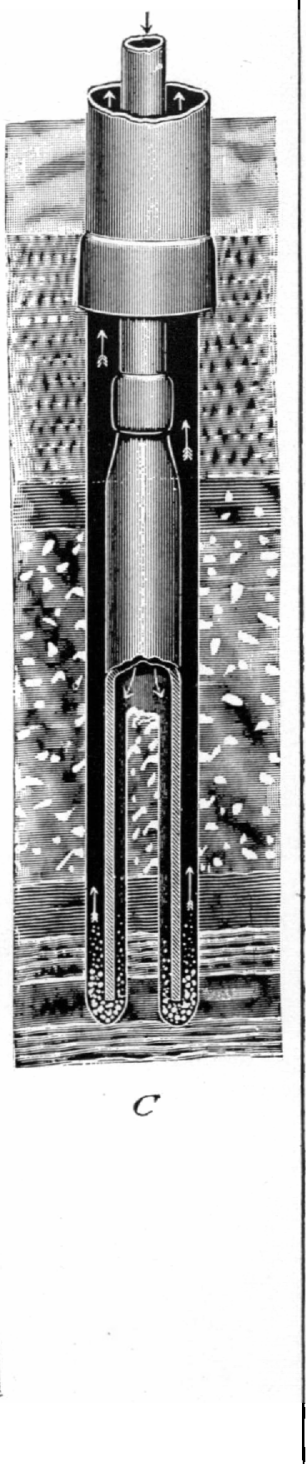

A. FISH-TAIL BIT

I. CORE-BARREL BIT.

(: ADAMANTINE OR SHORT DRILL. 

and a sufficient supply of water passing through, as a stoppage for a short time often "sticks" the work, and considerable time is lost, as the rods and often the casing already in place have to be withdrawn from the well.

In starting a well, arrangements are generally made for the insertion of a 12-inch casing to begin with, and in boring for this size the drill rods are generally made of 6 -inch casing with a 13 -inch bit. This sized bit is used to allow the collars at the joints of the 12-inch casing to slide past without damaging the wall of the well. The length of 12-inch casing used varies from 500 to 800 feet, depending largely upon the nature of the ground and the skill of the driller. The hole is generally left open until the whole depth calculated for one string of easing has been drilled. This generally extends until a hard stratum is met with, upon which the easing to this depth may stand. When the depth has been reached, the drill is withdrawn and the casing set.

Following the 12-inch casing the hole is next drilled for an 8-inch or 9-inch casing. In either case a $10 \frac{1}{2}$-inch bit is used. This 9-inch casing has in several of the Spindletop wells been placed in the oil sand. After setting the 9-inch casing the drilling proceeds downward with a 6 -inch casing. Oceasionally a still further reduction to a 4 -inch or eren 2 -inch becomes necessary.

\section{COST OF DRILLING.}

The drilling of the well is usually carried on by contract. Some few of the companies own their own outfits and drill on the company's account. During the earlier period of the history of the field sereral of the companies bought drilling outfits and erected the derricks. When new companies were rapidly springing up, it was usual to find the companies investing money in drilling machinery, and the alluring sentence that the work had actually been begun on the company's holdings "by the erection of a derrick" appears in many of the prospectuses issued at that time. This was chiefly for the purpose of inducing people to buy stock. At that time it was also the rule of the company to provide the casing, the contractor finding the tools and doing the work. Later the contractor was generally required to furnish everything and turn over the well to the company upon its completion. The contract in proved territory usually calls for a specified depth, or a good flowing well if found at a less depth.

Prices vary in accordance with the conditions of the contract, but from $\$ 4$ to $\$ 4.50$ per foot may be considered as a fair average of prices at Beaumont after the early excitement had subsided, the contractor furnishing all machinery, tools, labor, etc., necessary to drill the well. The company usually reserved the right to accept or reject the work upon completion.

The average time required to drill a well in any of the oil fields 
when no accident occurs is about two months. Several wells on Spindletop have been drilled in less than one month, but the greater number of them have occupied between two and three months. The work is often kept up night and day, though most of the contractors are content to keep the pumps at work all night without attempting to drill.

\section{FINISHING THE WELL.}

When the well approaches completion, the drill rods are withdrawn and a gate valve fitted to the casing in such a way as to permit of a rapid closing of the well if desired. When the valve is in position, the bit is again lowered and the work proceeds until the oil sands have been reached and penetrated to a sufficient depth to insure a flow in the well. The drilling tools are then withdrawn; the water bailed, and the well allowed to flow. When a sufficient time has elapsed to allow of the well cleaning itself of all loose pieces of rock or gravel, the valve is closed and the well shut in. None of these wells has been torpedoed. This method of inducing a flow was tried in one case on Spindletop and the only result was a ruined well.

Consiclerable danger accompanies the flowing and closing of a new well on account of the poisonous nature of the gas accompanying the oil flow. This gas contains a large proportion of hydrogen sulphide and its poisonous qualities are intensified by its being saturated with petroleum vapor. Petroleum vapor has the effect of rendering persons inhaling it unconscious, and if one remains under its influence for any length of time death ensues. The combination of the hydrogen sulphide and petroleum vapor issuing from the wells is such as to render death almost instantaneous. Few fatal accidents of this kind have taken place at Spindletop, however, but often driller's and others have been overcome and but for timely assistance would have been killed. The only deaths resulting so far from this cause connected with a well is that of the Palestine and Beaumont well, when three men lost their lives. Owing to an accident the drill rods got fast in the well and when the oil flow came it could not be closer on account of the rods being in the valve. To remedy this these men went into the derrick and attempted to unscrew the rod, but were overpowered by this mixture of gas and vapor and killed before assistance could reach them. One of the Higgins Oil Company's tank men was killed by the same cause when on the roof of a tank. 


\section{IN D EX .}

Anse la Butte, La., well record at wells at .......................... 130-131

Arcadia Parish, La., geologic section in.... 64 geology of .......................... 62

Asphalt, early reference to occurrence of.. $\quad 12$ in Sour Lake district ................. 113

Austin County, Tex., geology of ......... 32

Barber Hill, prospecting at .............. $\quad 127$

Bayous, coast, character of ............... $\quad 29$

Beaumont, Tex., geologic section at...... 61 geology of region.................. 32

Beaumont clays, deposition of ........... 67 described . . . . . . . . . . . . . . . . . . . . . 27-29 occurrence of..................... 20,45, 125

Beaumont district, Tex., described ...... 68-104

Big Hill, Jefferson County, Tex., well at... 126

Big Hill, Matagorda County, Tex., geology of... well at.

Bitumen, early reference to occurrence of

Brazoria County, Tex., geology of.... 32, 35-39, 65

Brazos River, geologic sections on ........ 32-42 geology of region.................... 29

Bryan Heights, Tex., well at............ 127

Burkeville, Tex., geologic section at...... 57

Burkeville beds, synonym............ 22, note

Calcasieu Parish, La., geologic section in.. 64

Calhoun County, Tex., well record in...... 34; 35

Cameron County, Tex., dunes in.......... 16 geology of .............................. prospecting for petroleum in...........

Cedar Bayou, well record on.

Chambers County, Tex., well record in....

Chicoleet, North, geologic section on .......

Chocolate Bayou, geologic section on .......

Coastal Plain, Gulf. See Guli Coastal Plain.

Colmesneil, Tex., geologic sections at......

Colorado County, Tex., geology of ..........

Colorado River, geologic sections on .......

Columbia, Tex., well record near .......... to

Columbia sands, described .............. $\quad \mathbf{2 6}$

deposition and erosion of $\ldots \ldots \ldots \ldots \ldots, 66,67$ occlirrence of ...... 11, 17, 20, 56-58, $65,119,125$

Cooks Mountain beds, occurrence of...... 20

Corpus Christi, geology at................ 18

Cretaceous rocks, in eastern division of Gulf Coastal Plain.......... 20, 23, 24

Cypress, occurrence of .................... 15

Damon Mound, geology of .............. $6 \overline{6}$

well records at ..................... $35-39$

Davis Hill, Tex., conditions at ........... 127

Dayton Hill, Tex., well at................. 126

well record at ........................ $46-47$
Page.

efert, of Texas ......... 16

Dewitt County, Tex., geologic section in .. 31

Diatoms, possible source of petroleum... 108-111,

138

Drainage of the region ................. 14-15

Dunes, on Gulf Constal Plain............. 16

Dural County, Tex., geology of ........... 17

prospecting for petroleum in.......... 19

Edgerly, La., well near ................. 137

Eocene rocks, in eastern division of Gulf

Coastal Plain . ............... 20,23, 24

in Newton County, Tex .............. 53

in region surrounding Spindletop pool. $\quad 87$

Fayette clays, occurrence of .............. 29

Fayette sands, defined .................. $\quad 21$

occurrence of ...................... 20 $21,31,32,42,43,49-51,54,55,57$

Flash point, discussed ............... 147-148, 159

Fleming beds, synonym ............. 22, note.

Forests, occurrence of ............ 10,15,16, 28

Fossils, Eocene, list of, from Beaumont district ........................ 25

list of, from Newton County, Tex.....

occurrence of, in Coastal Plain generally.........................

in region surrounding spindletop pool ........................

Fossils, Miocene, occurrence of, in Coasta] Plain generally ........... 20, 23-25

occurrence of, at Bayou City............

in region surrounding Spindletop pool

53

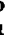

Fossils, Pleistocene, occurrence of, in Coastal Plain generally .............. 20,27

occurrence of, in region surrounding Spindletop pool .............. 87

Fossils, Pliocene, list of, from Beaumont district .................... 25

occurrence of, in region surrounding Spindletop pool ................

Fossils, Recent, occurrence of, in Coastal Plain generally ......... 19, 27, 29, 30 occurrence of, in region surrounding. Spindletop pool .............. 87

Fossils, Tertiary, list of ................... 24

Frio clays, described $\ldots \ldots \ldots \ldots \ldots \ldots \ldots 22,27,43$ erosion of ........................ 66 occurrence of .. $20,21,29,30,32,35,12,43,50-57$ Fuel, Texas-Louisiana petroleum as ..... 158-165 Furnace, boiler, with oil-burning equipment, sketches of........... 163, 164

Galveston, well at, depth of ............. 45 well record at ..................... 48 
Page.

Gas, natural, at Anse la Butte, La......... 131 at Big Hill, Matagorda County, Tex. 41, 42, 127 at Bryan Heights, Tex............... 127 in Coastal Plain generally............ 154 at Damon Mound, Tex.............. 40,42 at Davis Hill, Tex................. 127 at Dayton Hill, Tex ................ 126 at Fairchild Hill, Tex................ 48 at Hackb rry Island, La . . . . . . . . . . . 133 at High Island, Tex............... 122, 123 at Kiser Hill, Tex ................. 125 in Sabine Parish, La.................. 55 near Sabine Pass, Tex............... 113 in Sour Lake district . ............... 113,116 at Tilden, Tex ....................... 18 at Velasco, Tex...................41, 42 Geologic history of Coastal Plain....... 66-67.145 Gravels at base of Columbia beds......... 62-65 impediment to well drilling........... 65 Gravity, specific, of various petroleums... 146-147 Grimes County, Tex., geology of......... 43 Guadalupe River, geologic sections on ... . . 30-32

Gulf Coastal Plain, defined .............. 10,13 eastern division, geology of ........... 19-30 origin of ......................... 11-12 subdivisions of

topography of ................... 10-15

western division, geology of ........... 16-19 prospecting for petroleum in...... 19

Hackberry Island, La., wells at ......... 131-133

Hardin County, Tex., well records in ..... 59,60

Harris County, Tex., geology of.......... 45

Hidalgo County, Tex., dunes in .......... I6 geology of ............................ 17

High Island, geology of .............. 122-125 sketch contour map of ............... 123 well record at ........................ 124

History, geologic, of Coastal Plain ..... 66-67, 145 Hornbeck, La., geologic section at ........ 53 Houston, Tex., geology of region......... 32 Houston County, Tex, geology of......... 49 Huntsville, Tex., well record at .......... 45

Illuminating oil, suitability of Gulf coast petroleum for .............. 157

Irish Creek, geologic section on............

Iron, precipitate of, mistaken for petroleum ...........................

Islands, coast, occurrence of .............. origin of $\ldots \ldots \ldots \ldots \ldots \ldots \ldots \ldots \ldots$ i1

Jasper County, Tex., geology of......... 49, 51

Jefferson County, Tex., geologic section in. 61

Jennings district, La., geology of ........ 127 map of............................ 128 wells in, list of .................... 130

Keys, along coast..................... $\quad 42$ origin of .......................... 11

Kiser Hill district, described.............. 125 well record in ...................... 40

Lafayette sands, described ............... $\quad 26$ deposition and erosion of ............. 66 occurrence of ............. 11, 20,44,56,65, 125

Lagoons, along coast ................... 42

Lake Charles, La., geology of ............ 28 well record at ....................... 136

Liberty County Tex., geology of.......... 45

Lignite, occurrence of. $20,51,87$
Prge.

Little Sandy Creek, geologic section on.... 51 Live Oak County, Tex., geology of ........ 17 Logs of wells. See Wells, records of. McMullen County, Tex., geology of........ 17 Magnolia, occurrence of ................. 15 Maltha, early reference to occurrence of... $\quad 12$

Marshes, coast....................... 29,42 interior............................. 28 salt ..................................

Matagorda Bay, geology of region........ 34, 35 Medanos, on Gulf Coastal Plain........... 16 Mesquite, distribution of ................ 15 Miocene rocks, in eastern division of Coastal Plain .................. 20,23, 24, 26

in western division of Coastal Plain.... 17 between Brazos and Trinity rivers..... $\quad \mathbf{4 4}$

in region surrounding Spindletop Pool. $\quad 87$ Nontgomery County, Tex., geology of ..... 43,44 Mount Selman beds, occurrence of........ 20 Neches River, geology of region ........ 28,48-61 Neocene rocks in eastern division of Gulf Coastal Plain ................. 20, 24

New Iberia Parish, La, geology of......... 62 Newton County, Tex., geolog ic section in . $\quad 57$ geology of .......................49,51 Nueces River Valley, geology of........... 17 Oak, occurrence of . . . . . . . . . . . . . 15, 16 O'Connorsport, Tex., well record at....... 34, 35 Oil. See Petroleum.

Oil ponds, Sabine Pass ............... 104-112 Oligocene rocks in eastern division of Coastal Plain ............... 23 Orange County, Tex., geology of ......... 28, 32 Perryville, geology of region ............. 31 Petroleum at Anse la Butte, La ......... 63, 131 at Damon Mound, Tex ............ 37, 38, 40 at Hackberry Island, La............ 133 at High Island, Tex ............... 124, 125 in Jennings district, La., quality of .... 129 list of wells producing ............ 130 at Kiser Hill, Tex .................. 125 in minor Louisiana districts......... 135-137 in minor Texas districts . . . . . . . . . . . . 125-127 in Sabine Parish, La................ 55, 113 at Saratoga, Tex.................... 59,60 at Sour Lake, Tex ............... 116-118 at Sulphur, La.................. 133,135 at Vinton, La...................... 135 conditions of accumulation of, dis-

cussed ...................... 140-145

diatoms as possible source of ..... 108-111, 138 distillation of, discussed ............. $150-153$ early references to $\ldots \ldots \ldots \ldots \ldots \ldots \ldots 12,113$ effects of inhaling vapor of.......... $\quad 170$ geologic source of .................. 23, 25 iron precipitate mistaken for ......... $\quad 45$ oil ponds of Sabine Pass............ 104-112 origin of, discussed.......... 108-111, 137-140 pressure in wells, discussed ......... 154-157 producing districts, list of............. $\quad 68$ producing rock, nature of, in Jennings district, La .................. 129

in Spindletop pool ............... $70-71$ relation to salt water................ $\quad 119$ Texas-Louisiana, chemical properties of ........................ 148-154 
Petroleum, Texas-Louisiana, physical properties of ................ 146-148 Texas-Louisiana, utilization of....... 157-166 wells producing, in Jennings district, La .......................... 130

at Spindletop.................. $77-85$

See also Structure, geologic; Beaumont district; Saratoga district, etc.

Pimpled plains, described

Pine, occurrence of.

(n..................

Plateau gravels,

Pleistocene rocks, Columbia sands.........

at base of Columbia beds.

in eastern division of Coastal Plain.... near San Diego.

in region surrounding Spindletop poil

Pliocene rocks, in eastern division of Gulf Coastal Plain............. 20, 25,26 in western division of Gulf Coastal

Plain ..................... 17, 18

between Brazos and Trinity rivers..... 44 in region surrounding Spindletop pool. $\quad 87$

Polk County, Tex., geologic sections in.... 50,52 Feology of ...................... 49, 52 well record in

54

Port Arthur, well record neer............ 112

Port Arthur-Sabine Pass district, described 104-113. prospecting in ..................... 112-113

Port Hudson clays, occurrence of....... 17,27, 29 Recent rocks, in eastern division of Gulf Coastal Plain ............... 19, 29 in region surrounding Spindletop pool. $\quad 87$ Reynosa limestone, occurrence of...... 17, 18, 41 Rockland, Tex., geologic section at....... $\quad 50$ Sabine Parish, La., well in............... 137 well record in.

Sabine Pass, map of showing oil ponds . well record near.................... 113

Sabine River, geologic sections near...... 48-61 geology of region.............. 28, 29,49.58

St. Martins Parish, La., geology of........ 62

St. Marys Parish, La., geology of.......... 62

Salt, conditions of accumulation of ...... 143, 144 at Anse la Butte, La ................ 63, 131 at Damon Mound, Tex .............. 36,37 at Dayton Hill, Tex .............. 46-47, 126 at High Island, Tex ................ 122 at Sabine Pass ..................... 113 in Sal del Rey region................. 17 at spindletop . ........................ in region surrounding Spindletop pool. near Tilden, Tex ......................

Salt licks and salt marshes................

Salt water, relation to oil ..........................

San Jacinto County, Tex., geology of . ..... 43,64

Saratoga district, history and geology of. 119-122 map showing........................ 114 well records in .................. $59,120-121$

Sea wax, described

Section, geologic, general, eastern division of Gulf Coastal Plain .......... 19-20

general, Pleasanton to Palito Blanco .. Beaumont district.

Frio beds, between Brazos and Trinity rivers

San Jacinto County, Tex
Section, geologic, Guadalupe River........ 30,31 Jefferson County, Tex., at Beaumont .. 61 Little Sandy Creek .................. 51 Teches and Sabine rivers ............ 48-61 Newton County, Tex................ 57 Polk County, Tex ............... 50, 52,54 Rockland, Tex .................... 50 Tyler County, Tex ................. 56, 57 Vernon Parish, La., at Hornbeck ..... $\quad 53$ Section, sketch, of Spindletop pool......... 73

Sour Lake district, geology of........... 113-119 maps of............................ 114,115 prospecting in...................... 114 well records in ................... 116,117 Specific gravity of various petroleums ... 146-147 Spindletop pool, geology of . . . . . . . . . . 69-77 graveis at..........................64-65 limits of ............................ 69 producing wells in, list of ............. $77-85$ sketeh section of ..................... 73 well records at . ..................... 74-77 region surrounding, geology of ........ 85-102 map of ........................ 86 dry and abaridoned wells in, list of ......................... 103-104 well records in .................. $8 \mathrm{i}-102$

Spring Hill, La., well at ................ 136

Starr County, Tex., dunes in............. 16 geology of ......................... 17 Stillson, Tex., well record at............. 47 Storage of oil ......................... 165-166 Structure, geologic, of petroleun beds ..... 142,

144-145

theoretical, of oil pool, sketch of...... 157 of Coastal Plain ................. 113-145 of High Island, Tex ................. 125 of Spindletop................... 72-74 of Sour Lake district ................ 118 of Sulphur, L $\ldots \ldots \ldots \ldots \ldots \ldots \ldots \ldots . .134$ Sulphur, in various petroleums ......... 149-150 in water and clay .................. 17, 18 at Damon Yound, $\mathrm{T} e x . . . \ldots \ldots \ldots \ldots . . .36-38$ at High Island, Tex................ 122 at Spindletop..................... 71 in region surrounding Spindletop pool. 87 at Sulphur, La .................... 133-135 Sulphur, La., wells at ................ 133-135 Tertiary rocks, occurrence of ............ 23, 65 Texas State Geological Survey, cited ...... 11 Timber, occurrence of............. 10, 15, 16, 28 Topography of the region, generul. ....... 10-15 Transportation of oil ................. 165-166 Trinity River, geology of region ..... $28,29,49,58$ Tyler County, Tex., geologic sections in ... 56, 57 geology of ........................ 49,64 Uvalde formation, occurrence of......... 65 Valda, Polk County, Tex., well record at .. 54 Vermilion Parish, La., geology of ....... 28, 29, 62 Vernon Parish, La., geologic sections in... 53,64 Victoria County, Tex., well record in...... 33 Village Creek, Tex., geology of region ..... 58 Vinton, La., well record at.............. 135 Walker County, Tex., geology of........... 44 Waller County, Tex., geology of .......... 43,44 Warren, Tex., geologic sections at ......... 57 Water, hot, from wells at High Island, Tex. 122 hot, from well at Saratoga, Tex........ 60 
Page.

Water, in artesian wells .......... 18, 87, 118, 12: salt, relation to petroleum. ............. 119

Wax, sea, described ................. 111

Wells, drilling of . . . . . . . . . . . . . . . . 166-170 drilling of, impeded by gravel ........ 65 artesian, on the Colorado and Brazos.. 33 at Beaumont, possible............ 87 at High Island, Tex............... 122 in Nueces County, Tex............ 18 at Sour Lake, Tex.............. 118 hot-water. . . . . . . . . . . . . . . . . 60, 122 list of, in Jennings distriet, La ....... 130 in Spindletop pool ............... $7-85$ dry and abandoned, in region surrounding Spindletop........ 103-104 pressure in, discussed ............... . 154-157 records of, at Anse la Butte, La ......63,130 in Arcadia Parish, La ............ 64 in Calcasieu Parish, La........... 64 in Calhoun County, Tex., at O'Connorsport 34.35 on Cedar Bayou ................. 46 in Chambers County, Tex., at Winnie

at Damon Mounä, Tex. $37-39$ at Dayton Hill, Tex at Galveston, Tex.

erry Island, La

in Hardin County, Tex.
Wells, records of, at Huntsville, Tex records of, at Kiser Heights, near Columbia, Tex .................. 40 at Lake Charles, La .............. 136 in Liberty County, Tex...........46,47 in Polk County, Tex., at Valda .... 54 at Port Arthur, Tex ............ $\quad 112$ in Sabine Parish, Ia ............. 55 at Sabine Pass.................. 113 at Saratoga, Tex............... 120,121

in Sour Lake district ............ 116,117 at Spindletop................ $74-77$ in region surrounding spindletop pool ....................... 87-104 at Stillson, Tex................. 47 at Sulphur, La . . . . . . . . . . . . . . . 133-135 in Tyler County, Tex............ 57 in Vermilion Parish, La.......... 64 at Victoria, Tex ................ 33 at Vinton, La.................. 135 Welsh, La., well at. . . . . . . . . . . . . . . . 136 Wharton County, Tex., geology of ....... 32 Wills Point clays, occurrence of . . . . . . . . . . 20

Winnie, Tex., well at. ................. 126 well record near...................., 61 Wood, deeply buried, in region surrounding Spindletop Pool ............. 87 Woods, presence of . . ........... 10, 15, 16, 28 Yegua clays, occurrence of............ 20,51 